\title{
Molecular characterization of haemoglobinopathies in the Surinam population
}

Citation for published version (APA):

Codrington, J. F. (1992). Molecular characterization of haemoglobinopathies in the Surinam population.

[Doctoral Thesis, Maastricht University]. Rijksuniversiteit Limburg. https://doi.org/10.26481/dis.19921126jc

Document status and date:

Published: 01/01/1992

DOI:

10.26481/dis.19921126jc

Document Version:

Publisher's PDF, also known as Version of record

\section{Please check the document version of this publication:}

- A submitted manuscript is the version of the article upon submission and before peer-review. There can be important differences between the submitted version and the official published version of record.

People interested in the research are advised to contact the author for the final version of the publication, or visit the DOI to the publisher's website.

- The final author version and the galley proof are versions of the publication after peer review.

- The final published version features the final layout of the paper including the volume, issue and page numbers.

Link to publication

\footnotetext{
General rights rights.

- You may freely distribute the URL identifying the publication in the public portal. please follow below link for the End User Agreement:

www.umlib.nl/taverne-license

Take down policy

If you believe that this document breaches copyright please contact us at:

repository@maastrichtuniversity.nl

providing details and we will investigate your claim.
}

Copyright and moral rights for the publications made accessible in the public portal are retained by the authors and/or other copyright owners and it is a condition of accessing publications that users recognise and abide by the legal requirements associated with these

- Users may download and print one copy of any publication from the public portal for the purpose of private study or research.

- You may not further distribute the material or use it for any profit-making activity or commercial gain

If the publication is distributed under the terms of Article $25 \mathrm{fa}$ of the Dutch Copyright Act, indicated by the "Taverne" license above, 


\title{
Molecular characterization of haemoglobinopathies in the Surinam population
}

\author{
Proefschrift
}

ter verkrijging van de graad van doctor aan de Rijksuniversiteit Limburg te Maastricht, op gezag van de Rector Magnificus, Prof. mr. M.J. Cohen, volgens het besluit van het College van Dekanen in het openbaar te verdedigen op donderdag 26 november 1992 om 16.00 uur

door

John Frits Codrington 


\section{Promotores:}

Prof. Dr. P.J. Brombacher

Prof. Dr. T.H.J. Huisman (University of Georgia, U.S.A.)

\section{Beoordelingscommissie:}

Prof. Dr. J.P.M. Geraedts, voorzitter

Prof. Dr. J.W. Arends

Prof. Dr. L.F. Bernini (Rijksuniversiteit Leiden)

Prof. Dr. H.C. Hemker

Prof. Dr. R.H. Kuijten 


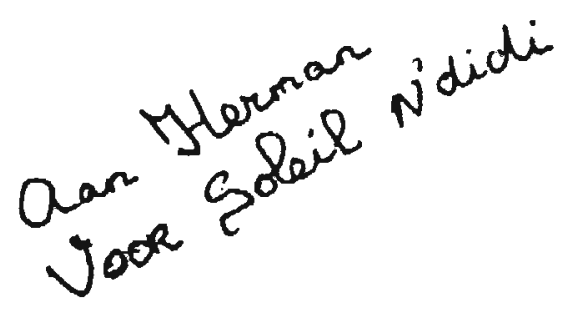

Aan Herman

Voor Soleil N'didi 


\section{CONTENTS}

Introduction.

Chapter 1

Haemoglobinopathies: A Review.

Chapter II

Materials and Methods.

59

Chapter III

Structural variants in the Surinam population.

75

a. Hb Chad or $\alpha_{2} 23(B 4)$ Glu $\rightarrow$ Lys $\beta_{2}$ observed

in members of a Surinam family in association

with $\alpha$-thalassaemia- 2 and with $\mathrm{Hb} \mathrm{S}$.

(published in: Hemoglobin 13: 543-556; 1989)

b. The $\beta^{s}$ gene in the Surinam population:

89

Haematological and genetic observations.

Chapter IV

Thalassaemias in the Surinam population.

a. Molecular characterization of $\beta$-thalas-

saemia among Surinamese.

b. Compound heterozygosity for a mild $\beta^{+}$and a rare $\beta^{\circ}$-thalassaemia allele.

(published in: Acta Haematol. 84: 135-138; 1990)

c. Observations on the levels of $\mathrm{Hb} \mathrm{A}_{2}$ in

patients with different $\beta$-thalassaemia

mutations and a $\partial$ chain variant.

(published in: Blood 76: 1246-1249; 1990)

d. Hb E- $\beta$-thalassaemia in Surinam.

129

(accepted for publication)

Chapter V The Surinam $(\partial \beta)^{\circ}$-thalassaemia is due to a deletion of $31.6 \mathrm{~kb}$.

Summary.

Samenvatting.

Epiloog 
$$
\cdot
$$ 


\section{INIRODUCTION}

When the Spanish and Portuguese arrived around A.D. 1500 in what today is knownas Latin America, the Caribbean area, South and Central America, and parts of North America, they found a large mongoloid population which had probably arrived 30,000 years earlier from Northeast Asia. In some countries the new invaders brought waves of violence against the native population, a very high mortality rate due to epidemic diseases, and often mixed with the native races. During the long period of colonialism, several Latin American and Caribbean countries were passed with great ease from one Europcan power to another. It was during this period that the racial picture became further complicated by the large contribution of Africans. These were introduced to the American continent during three centuries, the West Indies being the centre of the slave trade. After the slave trade was abolished, the continent received waves of immigrants who greatly contributed to the formation of the present population. Venezuela and Argentina received important contributions of German and Italian populations; Chile of English and Italian; Brazil and Peru of Japanese, and Surinam of Javanese, Chinese, Lebanese, Dutch, and Asian Indians.

The population of Surinain $(\sim 500,000)$ is one of the most multi-racial populations in the world. Almost every race is represented and mixed breeds are present in all possible combinations. Almost the same number of people $(\sim 500,000)$ of Surinam origin live in The Netherlands. The history of the mixed population of Surinam will also be reflected in the actual picture of haemoglobinopathies in this population. The Surinam population has been the subject of several studies. The focus of these studies was primarily directed to studying the haemoglobin abnormalities in the native groups living in the interior rather than having a clear picture of the distribution of these disorders in the community at large; thus, little is known about the various haemoglobin variants and types of thalassaemia. The ethnic variability of the Surinam population will give rise to interactions of different $\beta$-thalassaemia genes which are common in certain populations (Negro, Chinese, Asian Indian, Mediterranean, and Indonesian) and with known haemoglobin variants. Identification of these interactions provides valuable information for the clinician and for the genetic counsellor because it identifies the cases in which prenatal diagnostic procedures are indicated.

The main objectives of the studies presented in this dissertation are:

a. To establish the types of haemoglobinopathies and thalassaemias in the Surinam population.

b. To provide data allowing the assessment of the usefulness of obligatory prenatal screening for the prevention and treatment of maternal and foetal morbidity. 

CHAPTER 1

HAEMOGLOBINOPATHIES: A REVIE H 


\section{CHAPTER 1}

\section{HAEMOGLOBINOPATHIES: A REVIEW}

1.1 Structural Variants - History. The history of the discovery of the haemoglobinopathies is related to the advances made in the basic sciences and to technical developnents in the biomedical field. The same can be said for the development of treatment protocols for certain anomalies. Many of these abnormalities have only recently been described. This is probably due to the fact that in the 19th century, advances in modern medicine were made mainly in Germany, England, and France, where carriers of hereditary haemoglobin $(\mathrm{Hb})$ disorders were rare, and research interest was primarily in the field of infectious diseases. The first account of an abnormal $\mathrm{Hb}$ in the medical literature was provided in 1910 by James $B$. Herrick, a Chicago physician who described a 20 -year-old Black male from Grenada, West Indies, with a severe anaemia (1). Herrick described the sickle shaped cells with considerable precision and suggested that they were a manifestation of a peculiar chemical or physical condition.

Retrospective studies showed that sickle cell disease had been recognized in West Africa for several centuries (2). The disease was given specific vernacular names by different tribes, such as "chwechweechwe" (Ga tribe), "nwiliwi" (Faute tribe), and "ahotutuo" (Twi tribe). In different tribes in West Africa and in Surinam, certain tribe members were known to have the ability to forecast imminent rainfall because of sudden onset of joint pains. These tribesmen were most likely sickle cell (SS) patients. It is still customary in many of the tribes today to treat sickle cell "pain" (crisis) by applying tattoos around the painful joints involved in the crisis. Some of the traditional medicines given to SS patients by the healing doctors of the different tribes are under investigation (3). Some fractions of Fagara zanthoxyloides Lam extracts are known to reverse sickling in vitro and significantly reduce pain in SS patients (4-6). A clinical trial with a purified extract from the root of Fagara was recently performed in Nigeria with encouraging results (7).

The first practical screening test for sickling cells was done in 1917 by Victor Emmel, an anatomist at Washington University in St. Louis, Missouri, who studied the first $S S$ patient recognized at that institution. He sealed a suspension of the patient's red cells between a microscope slide and a cover slip and noted that, with time, all the red cells assumed the peculiar sickle shape (8).

A new phase in the investigation was the study in 1949 by Linus Pauling and associates. Pauling analyzed haemolysates of SS patients by moving boundary electrophoresis and found that the $\mathrm{Hb}$ from a patient with sickle cell anaemia had a different mobility from that of a normal individual (9). Moreover, individuals with sickle cell trait had both Hbs in approximately equal amounts. This observation is seen as the foundation of the molecular biology field. After Pauling and his coworkers described the abnormal electrophoretic behaviour of $\mathrm{Hb} \mathrm{S}$, electrophoresis was generally adapted by researchers, and many Hbs with an abnormal electrophoretic mobility have been found in the course of the succeeding years $(10-13)$. 
The first description of a special form of $H b$ in newborns was given by Korber in 1866, who noticed that the Hb of adults rapidly denatured when a solution of sodium hydroxide was added, while the Hb of the newborn showed a much greater resistance to alkali denaturation (14). This investigation was extended by several investigators, and the occurrence of a special form of $\mathrm{Hb}$ in the foetus, newborn, and infant during the first months of life, was soon generally accepted (15-17).

The introduction of a new method, called fingerprinting, made it possible to determine the nature of the abnormality of Hb variants (18). By this means it was observed that the sixth amino acid residue from the $N$ terminal end of the chain, that is glutamic acid in $H b A$, is substituted by valine in $H b S$. The amino acid sequences in the $\alpha, \beta, \gamma$, and $\delta$ chains of the normal Hbs were determined (19-21), and it became possible to compare the primary structures of these different chains. In 1968, the tertiary structure of $\mathrm{Hb}$ was revealed by the Nobel prizewinning X-ray crystallographer Max F. Perutz, allowing him and Hermann Lehmann to discuss the molecular pathology of $\mathrm{Hb}$ (22). Sophisticated high performance liquid chromatography (HPLC) equipment, in combination with automated amino acid analyzers, have been the tools of choice in analyzing new structural variants for the past decade.

The recent biotechnology era, with the use of the polymerase chain reaction (PCR) technology, and its application in related analytical procedures, is without doubt the next technological development of importance for our understanding of the haemoglobinopathies. The use of these newer techniques and some of the older ones are the basis for the research described in this thesis.

1.2 Thalassaemia - History. Like sickle cell anaemia, thalassaemia (thal) was first described in the United States, even though it is more common in Mediterranean countries (23). The reason for this is most likely the fact that the laboratory was a separate domain for the bedside-oriented European physicians, while the microscope was linked to many distinguished American clinicians in establishing their diagnoses (24). Thomas B. Cooley and Pearl Lee first described $\beta$-thal in 1925 (23). The theory that thalassaemia is a hereditary disease was first suggested in 1938 by Caminopetros (24). In 1940 Wintrobe et al (25) described the hereditary transmission of this disease in some members of a family of Italian descent living in Baltimore, and in 1956, Huisman et al (26) demonstrated that normal Hb $F$ was present in the blood of patients with thalassaemia major. In 1957 , Kulkel et al discovered $\mathrm{Hb} \mathrm{A}_{2}$ and showed that this $\mathrm{Hb}$ occurred in about twice the normal quantity in the blood of $\$$-thal heterozygotes (27).

Pauling (28), Itano (29), and Ingram and Stretton (30) postulated the hypothesis that the abnormal expression of globin chains in thalassaemia was due to a complete or partial block of the $\$$ chain synthesis. This hypothesis was experimentally confirmed in 1965 by Weatherall et al (31) who evaluated the synthesis of $\mathrm{Hb}$ in vitro in reticulocytes of patients with thalassaemia using labelled amino acids. These studies showed an imbalance in the chain formation $(\beta / \alpha)$ caused by an impaired $\beta$ chain synthesis. The groundwork for the in vitro $\mathrm{Hb}$ synthesis was laid by Dintzis in 1961, who discovered that the synthesis of $\mathrm{Hb}$ chains on the ribosomes in the cytoplasm was dependent upon the genetic code of the messenger RNA 
(mRNA) (32). In 1964, Heywood et al (33) reported the synthesis in vitro of $\mathrm{Hb}$ in the reticulocytes. By adding labelled amino acids to the cuiture medium it became possible to study the relative rate of synthesis of the different $H b$ chains, a procedure that has been iniportant in the investigation of all thalassaemia syndromes. In the early 1970's the discovery of the enzyme called reverse transcriptase in certain tumour viruses made it possible to synthesize complementary DNA (cDNA) from mRNA templates $(34,35)$ and, because of the vast knowiedge of $\mathrm{Hb}$, had made it the first gene to be characterized at the molecular level.

Radiocatively labelled $\alpha$ - and $\beta$-globin CONA were used as probes to demonstrate a deficiency of functional globin mRNA in thalassaemia, to demonstrate globin gene deletion in hereditary persistence of foetal Hb (HPFH), and to isolate genomic sequences responsible for the globin peptides $(36,37)$.

In the late 1970 's, the use of restriction endonucleases was introduced in the study of the thalassaemias. It was possible to obtain a picture of the physical organization of globin genes and to study the precise location and extent of some of the gene deletions that give rise to different forms of thalassaemia (38-41).

The use of PCR followed by sequencing of amplified DNA to elucidate many uncharacterized thalassaemia genes has definitely become the tool of the 1990's (42-44).

\section{CLASSIFICATION OF HAEMOGLOBINOPATHIES}

Haemoglobinopathies are hereditary disorders of $\mathrm{Hb}$ formation, which affect the function of red blood cells. The two groups of disorders with which this thesis is concerned are the $\mathrm{Hb}$ variants and the thalassaemias.

The chemical structure of $\mathrm{Hb}$ variants is abnormal and the alteration in structure may affect the rate at which $\mathrm{Hb}$ is synthesized in vivo or the fate of the red cells that contain abnormal pigment (45). The thalassaemias differ from the $\mathrm{Hb}$ variants in that no abnormal $\mathrm{Hbs}$ are formed (there are however a few exceptions), rather, the rate of adult $\mathrm{Hb}_{6}\left(\alpha_{2} \mathrm{~B}_{2}\right.$ ) formation is diminished, and as a consequence, various combinations of normal polypeptide chains may exist in abnormal quantities. The thalassaemias are characterized by hypochromic, microcytic red cells with an increased resistance to lysis by hypotonic solution (46).

\section{NORMAL STRUCTURE OF HUMAN GLOBIN GENES}

Human $\mathrm{Hb}$ is a tetrameric metalloprotein made up of two asymmetric dimers and four haem groups, as noted in 1930 by Anson and Mirsky (47). The iron ion associated with the haem structure nomally exists in the ferrous state. The dimers of adult $\mathrm{Hb} A\left(\alpha_{2} \beta_{2}\right)$ are designated as $\alpha$ and $\beta$ chains. The $\alpha$ globin gene complex encoding the human $\alpha$ polypeptides (141 amino acids in length) is located on chromosome 16 ( $F i g .1 .1$ ), whereas the \$-like globin gene complex on chromosome 11 encodes several $\beta$-like chains. Since all the structural genes for the $\mathrm{Hb}$ chains are autosomal, they occur 
A.
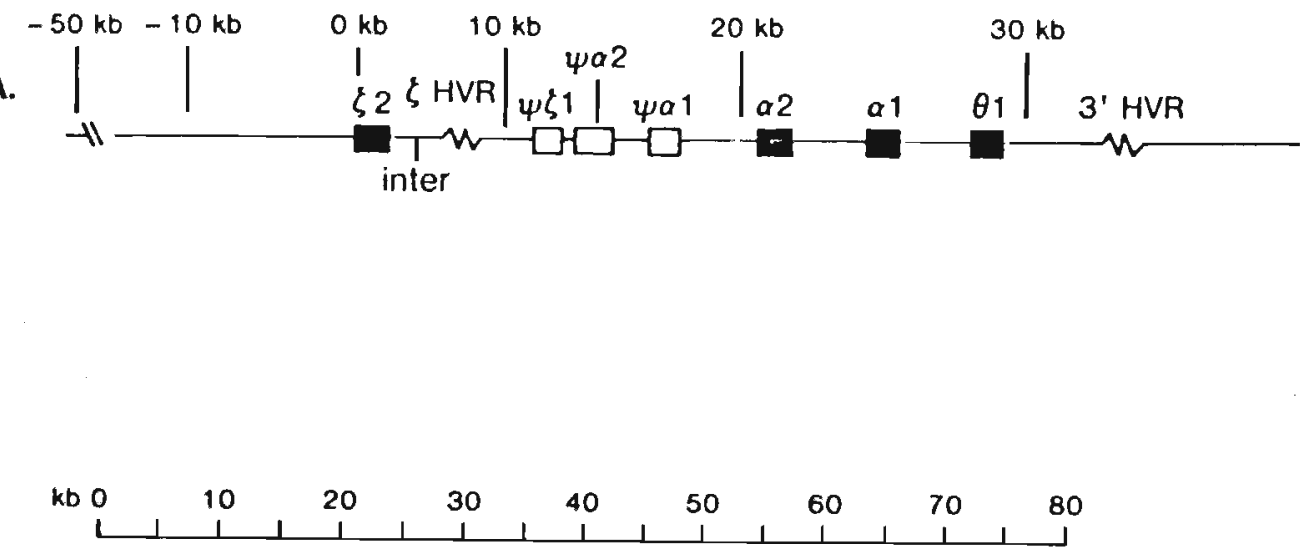

B.

\begin{tabular}{cccccc}
$\varepsilon$ & $\mathrm{G}_{y}$ & $\mathrm{~A}_{\gamma}$ & $\psi \beta 1$ & $\delta$ & $\beta$ \\
$\mathrm{m}$ & $\mathrm{m}$ & $\mathrm{m}$ & $\mathrm{m}$ & $\mathrm{m}$ & $\mathrm{m}$ \\
\hline
\end{tabular}

FIG. 1.1 Chromosomal Organization of the Human Globin Genes. A : Chromosome 16: Filled boxes represent coding genes and empty boxes the pseudo genes. B : Chromosome 11: Filled spaces in the boxes represent the exons and the blank spaces the IVS.

in pairs. If one of a gene pair is mutated or deleted, the individual is referred to as a heterozygote. If both genes of a pair have the same abnormality, the individual is designated as a homozygote. If both genes are affected but with different abnormalities, the individual is referred to as a compound heterozygote. The coding portion of each globin gene consists of three exons separated by two introns or intervening sequences (IVS). In the $\alpha$ gene, IVS-I is 117 base pairs (bp) long and separates codons 31 and 32, and IVS-II is 130 bp long and occurs between codons 30 and 31, and the IVS-II of about 850 bp divides codons 104 and 105 (Fig. 1.2). The intervening sequences are included in the precursor globin RNA transcript in the nucleus but are not present in in mature cytoplasm globin mRNA. The removal of these sequences from nuclear $\mathrm{mRNA}$ occurs prior to transport into the cytoplasm by a process referred to as splicing (Fig. 1.3) (i.e. introns are cut out and exons are joined together). The protein coding section of the genes are flanked on each side by untranslated sequences. At the $5^{\prime}$ end of the gene are present promoter regions that are important for the control transcription. Also at the $5^{\prime}$ end of the gene is found a region that is important for the correct termination of the translation. The pseudo genes, present in both the $\alpha$ - and $\beta-1$ ike gene clusters, are not expressed in functional globin products, although they have great homology with the functional genes. These genes are believed to be inactivated by mutations in coding and regulatory regions through evolution. 


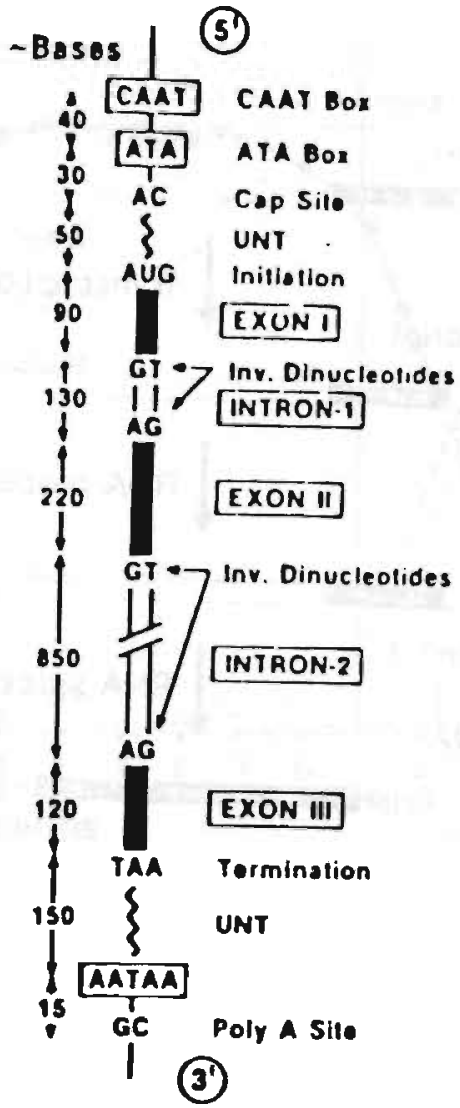

FIG. 1.2 Detailed Structure of a Globin Gene. The CAAT box is located approximately -72 nucleotides (nts) upstream from the Cap site. ATA box (Pribnow box or Goldberg-Hogness box) -26 nts upstream from the Cap site. UNT's are the untranslated regions. The AATAA box is located about 150 bases away from the termination codon and is the site of the polyadenylation (poly $A$ ) addition signal. The GC poly $A$ site is located about 15 bases $3^{\prime}$ from the AATAA box.

\section{THE REGULATION OF GLOBIN GENE EXPRESSION DURING DEVELOPMENT}

In early embryonic life $\mathrm{Hb}$ synthesis takes place in the yolk sac where 3 chains are synthesized and combine with $\varepsilon$ or $\gamma$ chains to form $\mathrm{Hb}$ Gower-I $\left(32 \varepsilon_{2}\right)$ or $H b$ Portland-I $(32 / 2)$, while $\alpha$ and $E$ chains can combine to form $\mathrm{Hb}$ Gower-II $\left(\alpha_{2} \varepsilon_{2}\right)(48-51)$. At about five weeks after conception, the switch from human embryonic to foetal $\mathrm{Hb}$ formation coincides with a change in the site of haematopoiesis from the yolk sac islands in the embryo to the liver in the foetus. Foetal $\mathrm{Hb}$ ( $\mathrm{Hb} F$ ) contains $\gamma$ chains and $\alpha$ chains and may be designated as $\alpha 2 \gamma 2$. There are two varieties of $\gamma$ chains that differ in their amino acid sequence at position 136, where 
B-globin gene

Exonl Exon II

Exon III

$\begin{array}{ll}\text { Promoler Intron I } & \text { Intion II } \\ & \\ \text { m-RNA Iranscript } & \text { Transcription }\end{array}$

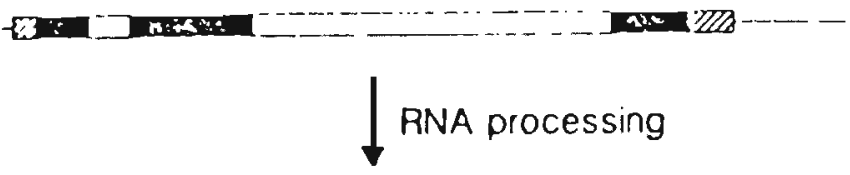

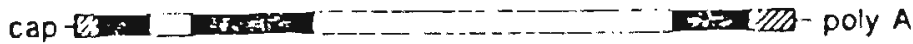

Mature m-RNA

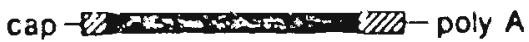

FI6. 1.3 B-Globin Structure and Expression. The hatched blocks at either end of the gene represent the $5^{\prime}$ and $3^{\prime}$ UNT's. The process of translation that occurs in the cytoplasm is not shown.

they have either glycine ( $G_{y}$ chains) or alanine ( $A_{\gamma}$ chains). The relative rate of production of the $G_{\gamma}$ and $A_{\gamma}$ chains is constant throughout foetal life at a $G_{\gamma}$ to $A_{\gamma}$ ratio of approximately 3 to 1 (52). The marrow starts to produce red cells during the second trimester and becomes the major erythropoietic site during later foetal and adult life. The production of the $\gamma$ chains gradually decreases during the third trimester and this is accompanied by an increase in $\beta$ and $\delta$ chain production. At term birth, the ratio between the $\beta$ and $\gamma$ chains is about 1 to $4( \pm 20 \% \mathrm{Hb} A$ and $80 \%$ $\mathrm{Hb} F$ ) (53). The $3 / \delta$ ratio is always $40: 1$ (54) (Fig. 1.4). During the first few months of 1 ife the Gr to Ar ratio changes from $3: 1$ to $2: 3$ in most infants (55). Less than $1 \%$ of the total $\mathrm{Hb}$ in human adults cells is $\mathrm{Hb} F$ and is restricted to a few erythrocytes called $F$ cells that also contain large amounts of $\mathrm{Hb} A$. The relative proportion of $F$ cells is remarkably constant in different individuals and appears to be genetically determined. Both the number of $F$ cells and the amount of $H b F$ in each $F$ cell may be increased in various acquired and genetic conditions characterized by elevated $\mathrm{Hb} F$ levels.

At all times, the amount of $\alpha-1 i k e$ and $\beta-l i k e$ globin chains are in a 1:1 ratio. The total amount of $\gamma+\beta$ is kept relatively constant. The $z$ and $\alpha$ chains are present early on in development. From six weeks onwards the $\alpha$ chains are the predominantly produced $\alpha$-like chains. The $\alpha$ chains are encoded by two different alleles; the major $\alpha 2$ gene and the minor $\alpha 1$ gene; both produce the same $\alpha$ protein. The relative rate of synthesis of 


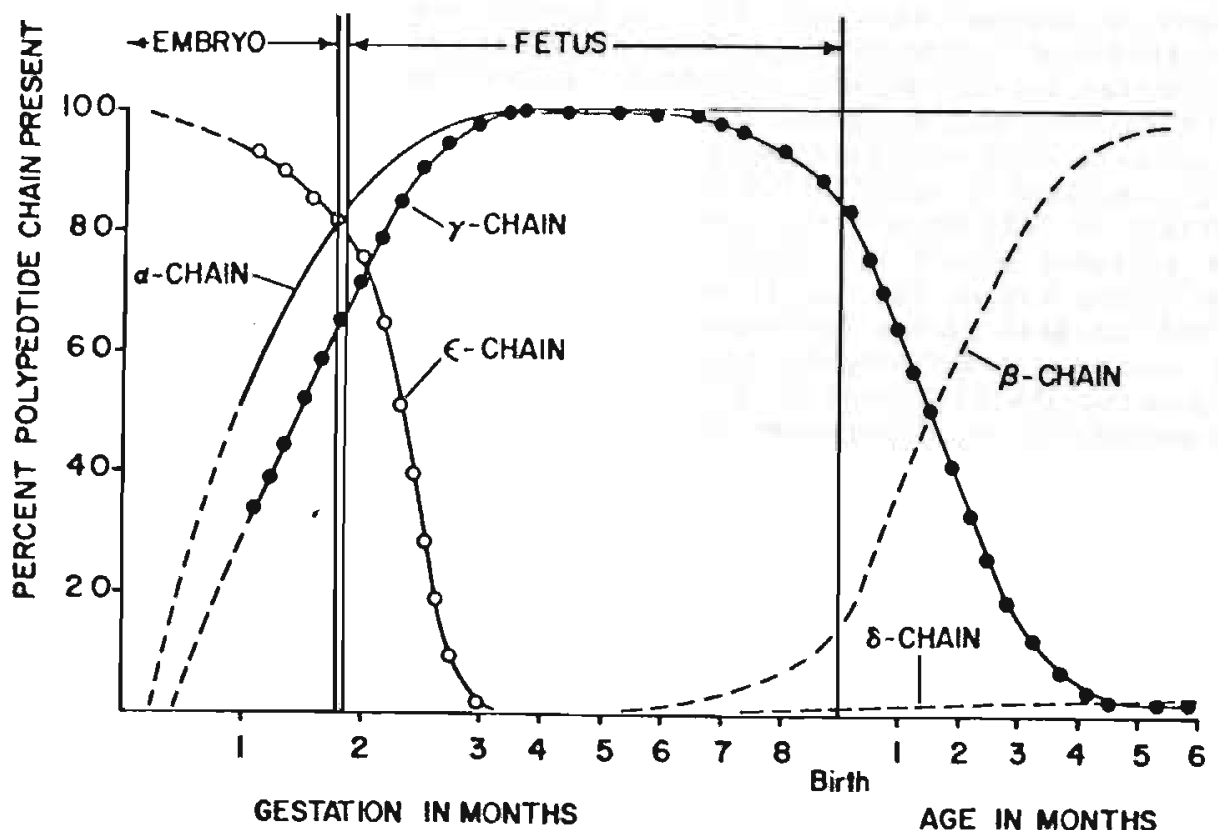

FIG. 1.4 Changes in globin chain production during the course of development.

protein by the two $\alpha$ genes is different. The mechanism(s) responsible for the regulation of $\mathrm{Hb}$ switches during foetal development is still poorly understood.

\section{MECHANISM OF HUMAN GLOBIN GENE EXPRESSION}

The selective expression of individual globin genes during development is regulated at the level of gene transcription by a) cis-acting control (regulatory) DNA sequences that are part of a globin gene or are nearly within the globin gene cluster, and b) trans-acting regulatory proteins with which the control sequences interact. At this level the expression of the globin genes is also regulated by the methylation stage of the genes.

The individual globin genes contain cis-acting regulatory sequences that define both tissue specific and developmentally specific patterns of expression. Cis-acting regulatory sequences include the promoter, coding sequences, enhancers, and some classes of repetitive DNA sequences.

5.1 Promoter. Promoter sequences are within 200 to 300 bp upstream or $5^{\prime}$ to the Cap site of the gene and only function in one orientation with respect to the coding portions of the gene. Sequence comparisons and functional assays have shown that promoters are composed of several functional elements or motifs, ranging from 6 to 20 nts in length. These elements 
are thought to interact with specific DNA binding proteins that facilitate and regulate transcription $(55,56)$. The most distal element of the $\beta$-globin gene is located between 90 and $105 \mathrm{nts}^{\prime}$ to the Cap site $(56,57)$; it is designated as the CACCC or CACCCT box $(58,59)$. The second conserved region is between 70 and $90 \mathrm{nts}$ upstream from the Cap site; this has the general consensus structure $5^{\prime}$-GGC/TCAATCT-3' (60). This element is referred to as the CCAAT (Or CAT) box and is found in the promoter region of many genes. The most proximal element is found approximately 30 bp upstream from the Cap site. This region is rich in adenine and thymine and is referred to as the ATA or TATA (Goldberg-Hogness) box. The TATA box appears to be directly involved in defining the exact transcriptional start site, presumably by binding RNA polymerase II (61). Fig. 1.5 campares the $n t$ sequences of the promoter of the different $\beta$-i ike genes.

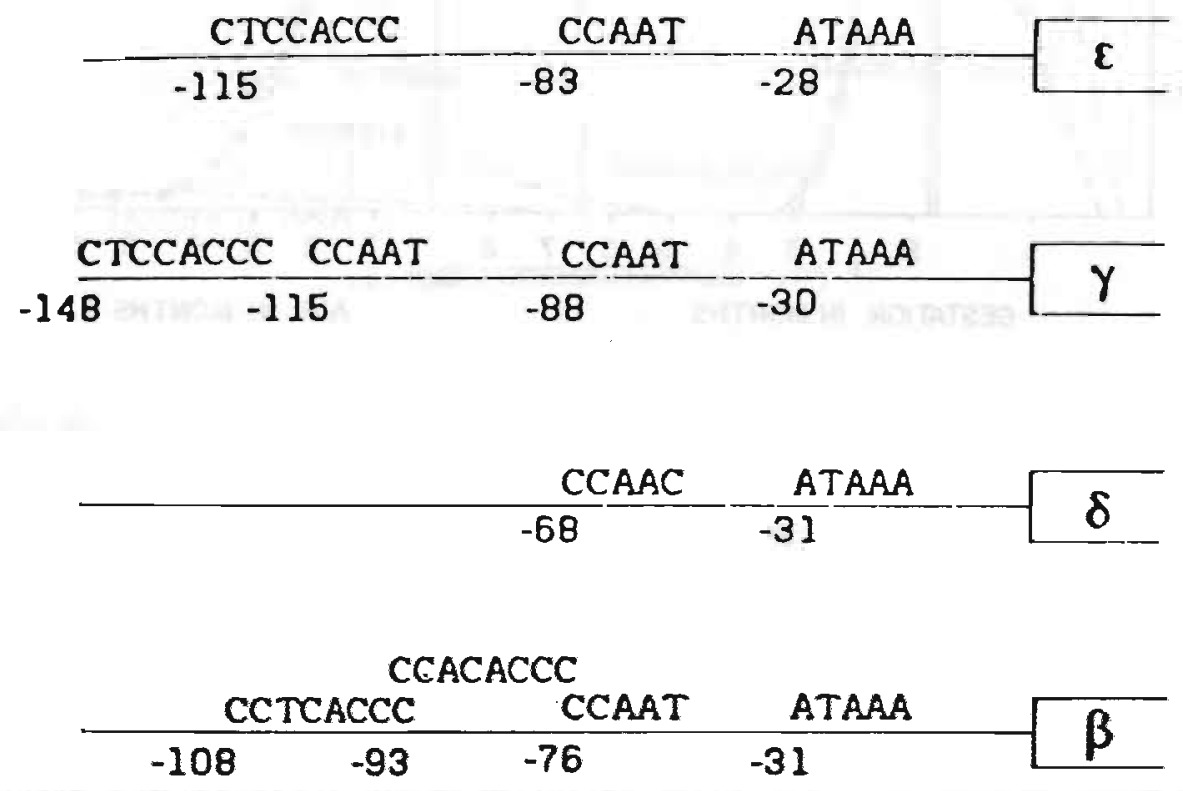

F16. 1.5 Human B-Like Globin Gene Promoters. The conserved blocks of DNA sequence in the promoter region of several genes are shown. By convention, nts upstream from the gene are numbered as minus the number from the first transcribed nt.

5.2 Enhancers. Enhancers are segments of DNA of variable length that Increase promoter function, independent of orientation and position with respect to the promoter. For example, a $\beta$-globin gene promoter is enhanced in in vitro experiments when the relevant DNA segment is placed on either side of the gene and in either orientation $(62,63)$.

The immunoglobulin (Ig) heavy chain gene was the first cellular gene found to possess an active enhancer (64). A number of other cellular enhancers such as those for the Ig light chain, insulin, $\beta$-interferon, human 
antithrombin 111 , and human placental lactogene genes, have since been identified. Cellular enhancers have been found in both the $5^{\prime}$ and $3^{\prime}$ flanking regions of their associated structural gene (65-69). Several functional elements analogous to the sequence "motifs" of promoters have been identified in enhancers, and they appear to interact with specific protein molecules $(70-73)$.

The enhancer requirement of rabbit and human 3 -globin gene promoters is shared by $\delta$ - and $\gamma-g$ lobin gene promoters $(74-76)$ but the $\alpha$-globin gene appears to possess enhancer activity within its coding sequences $(76,77)$. The requirement of the 3 -globin gene promoter for an enhancer in an in vitro expression can be replaced by addition of the adenovirus Ela protein, a transcriptional activator that apparently interacts with the ATA box region of the -globin gene promoter to stimulate transcription (78-80). Two points are apparent. First, the $\alpha$ - and $\beta$-globin genes appear to be regulated in different ways, and second, promoter activity may be achieved by different combination of linked-sequence elements and protein factors. The enhancer activity appears to be related to an increased density of RNA polymerase molecules on linked DNA $(81,82)$.

As in the promoter, enhancer elements have been shown to bind with transcriptional factors (83). The implication for the role of transacting factors is that cooperative binding of factors may be required for the mechanism of activation. Proteins (factors) that bind specifically to enhancer elements have been identified by DNA footprinting and gel retardation assays, and in some cases these proteins have been extensively purified $(84-87)$.

The types of regulation observed with cellular enhancers indicate that enhancers can be divided into two categories: those that respond to changes in the environment (inducible enhancers), and those that are active only at specific times during development or only in specific tissues (temporal and tissue specific enhancers) (88).

Numerous models have been proposed to account for the properties of enhancers (89). In one model, enhancers are assumed to act as entry sites for transcription factors that move to the promoter, where they have a direct effect on the initiation of transcription. This movement could occur in at least two distinct ways. The intervening DNA could loop out to bring the enhancer and associated factors into direct contact with the promoter (the looping model). Evidence supporting the loop model was obtained by examining the dependence of enhancer activity on the distance between the enhancer and the promoter (90). Rather than serving as a binding site for a factor involved directly in transcription, an enhancer could act to reorganize chromatin into a transcriptionally active conformation (the chromatin structure model). The enhancer is known to change the pattern of DNase hypersensitivity in linked DNA (1). A third possibility is that enhancers serve to modulate the superhelicity of linked DNA by providing sites for the action of topoisomerases, enzymes that can change the degree of supercoiling of DNA for transcription of a gene. In one version it was postulated that an eukaryotic type II topoisomerase (that normally will only relax DNA) gains a supercoiling activity when bound to a specific site, in this case the enhancer (92). Finally, enhancers could act by targeting the template to a particular location in the nucleus where transcription occurs (the nuclear address model) (93-94). 
5.3 Mcthylation of Globin Gencs During Development. The globin genes are hyponcthylated when expressed, and they are more completely methylated during developmental periods when they are not expressed $(95,96)$. Fig. 1.6 shows a diagram representing the relative methylation frequency of $C$ P $G$ residues within the cluster during various developnental stages. At all stages of ontogeny the $\beta-1$ ike globin genes show a strong correlation between their methylation state and expression. In the case of the human globin genes, the most remarkable association between hypomethylation and gene activity can be found in the $5^{\prime}$ flanking regions of the foetal $\gamma$-globin genes. The $5^{\prime}$ flanking DNA's of both the $G_{\gamma}$ - and Ar-globin genes contain a CCGG sequence at position -54 from the Cap site, about midway between the CCAAT and ATA boxes. Both sites are hypomethylated in foetal liver erythroid cells that have active $\gamma$-globin genes but are fully methylated in erythroid cells of adult bone marrow where $\gamma$-globin genes are not expressed to any significant degree. Methylation in the $5^{\prime}$ flanking region of DNA (residues -760 to +100 ) but not in the remainder of the $\gamma$-globin gene, prevented its expression in transfected tissue culture cells (97). Although DNA hypomethylation in 5' flanking DNA may be a prerequisite for gene expression, it is probably not the primary event responsible for the activation of the globin genes because there are many situations in which globin genes or other genes are hypomethylated but not expressed. 0ther factors must be responsible for triggering gene expression once the gene is in a state capable of being expressed.

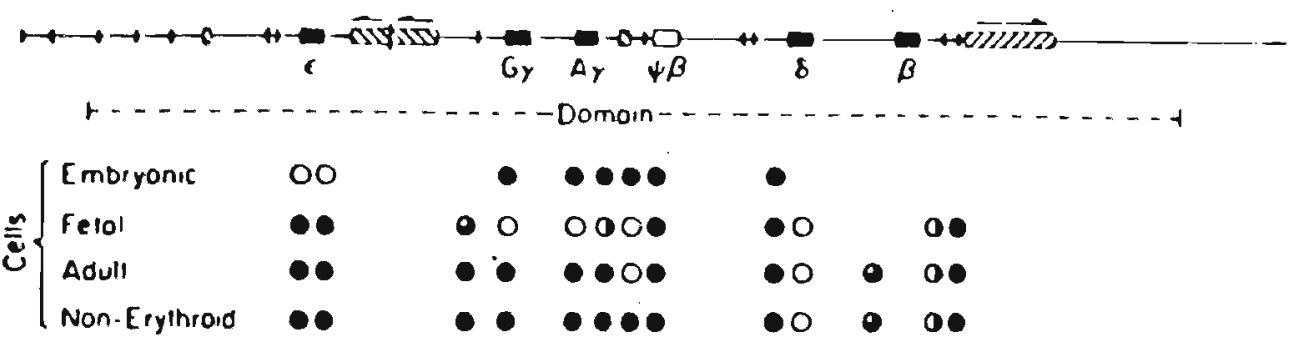

FI6. 1.6 Methylation Patterns of the Human $\beta$ Locus in Various Stages of Ontogeny. Open circles show an unmethylated site, filled circles a totally methylated site, and partially filled circles show the degree of site methylation. Reproduced from The Molecular Basis of Blood Diseases, by G. Stamatoyannopoulos et al, W.B. Saunders Company, 1987, with permission.

5.4 DNase I Hypersensitive (HS) Sites. DNase I HS sites have been found 5 , to the $6 \gamma-, A \gamma-, \delta-$, and $\beta$-globin genes in foetal liver haematopoietic tissue, but only $5^{\prime}$ to the $\delta$ - and $\$$-globin genes in adult haematopoietic tissue. These changes are presumably due to alterations in chromatin structure, both around the cluster reflecting its potential expression in erythroid cells, and within a cluster as each gene is activated at different times during development (98). 
Several authors' reports have identified a region important for erythroid specific expression of the $\beta$-globin gene complex $(99,100)$. These include a set of four DNase I HS sites at $-18,-14.7,-10.9$, and $-6.1 \mathrm{~kb}$ $5^{\prime}$ to the $\mathcal{E}$ gene and a $3^{\prime}$ HS site $21.9 \mathrm{~kb} 3^{\prime}$ to the $\beta$ gene (Fig. 1.7). The significance of these sites to globin gene expression has been demonstrated by Grosveld et al (101), who achieved high levels of position independent $\beta$ gene expression in transgenic mice by constructing a $\beta$-globin minilocus in which the most $5^{\prime}$ and $3^{\prime}$ HS sequences flank a $\beta$-globin gene. These HS sites are erythroid-tissue specific, developmentally stable, and have been termed locus-activating regions (LAR) or locus controlling regions (LCR) to imply the essential nature of their presence to pois chromatin structure of the $\beta$-globin locus for developmentally regulated transcription of the globin genes (102). Three large deletions that remove variable amounts of the upstream portion of the $\mathbf{\beta}$-globin gene cluster provided additional evidence for the potential importance of this DNA region in gene regulation. The part of the $\beta$-globin gene cluster removed by each deletion is indicated in Fig. 1.8. These deletions, which have been identified only in the heterozygous state, are characterized by a $\beta$-thal minor phenotype but with a normal $\mathrm{Hb} \mathrm{A}_{2}$ level (103-105). The interesting feature of these three deletions is that in each case an intact $\beta$-globin gene is present but not expressed. In the Dutch and English cases, the $\beta$-globin gene on the chromosome bearing the deletion is normal in expression studies in cultured cells and by sequence analysis $(106,107)$. The Hispanic deletion occurs on a chromosome bearing a $\beta^{5}$ gene that is not expressed. The $3^{\prime}$ endpoint of this deletion has not been precisely defined but falls within the region of the upstream major HS sites (105). Thus, it appears possible that the inactivation of these intact $\beta$-globin genes might be the result of a deletion of upstream sequences essential for expression.

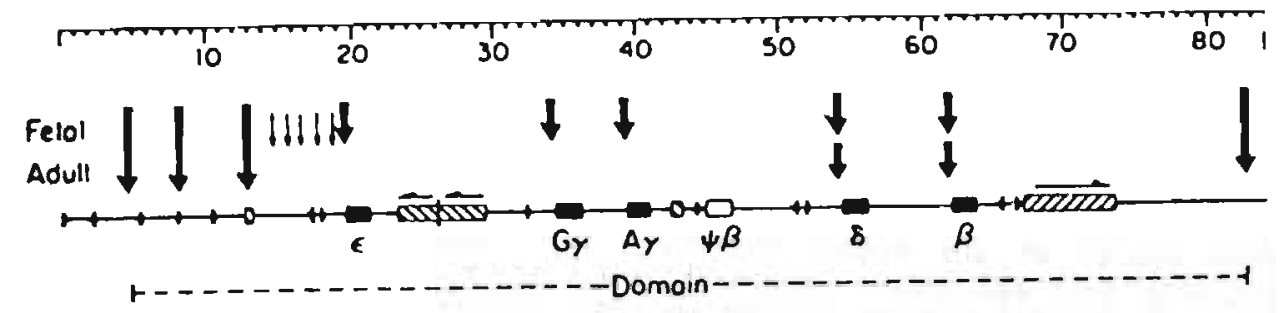

FI6. 1.7 Chromatin Structure of the Human $\beta$ Locus. The arrows show the location of the DNase I HS sites. The $\gamma$-globin gene HS sites are present only in the foetus, while $\hat{\beta}$ and $\delta$ gene sites are present in adult as well as foetal erythroblasts. The major HS sites marking the boundaries of the $\beta$ locus domain are present throughout human development.

5.5 Repetitive Sequences, KpnI and AluI. Several members of the two best characterized human repetitive DNA sequence families, the Alu and Kpn repeats, have been identified in the $\hat{p}$-globin gene cluster $(108-110)$. The 


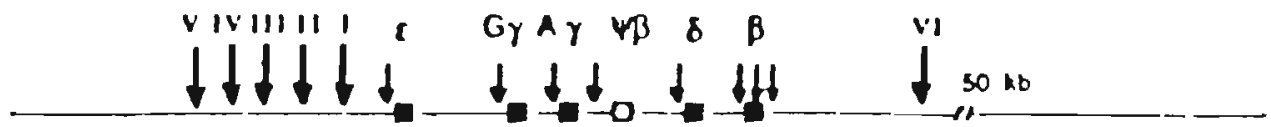

- Durah

$\longrightarrow$ Hispanic

English

FIG. 1.8 The portion of the $\beta$-globin gene cluster deleted in three cases of $\gamma \delta \beta$-thal are indicated by the 1 ines.

Alu sequences are repetitive DNA sequences approximately $300 \mathrm{nts}$ in length that are widely interspersed through all chromosomes of human DNA. The Alu family derives its name from a common AluI enzyme cleavage site found in $60 \%$ of its copies. Alu elements are thought to have been dispersed via an RNA intermediate that is converted into DNA by action of a reverse transcriptase prime off the poly A track (111).

There are eight members of the Alu repetitive sequence family in the $\beta$-globin gene cluster (48). Alu repeats appear upstream from the $\gamma$-globin genes and upstream from the $\psi \beta$ gene. Inverted pairs of $A 1 u$ sequences appear upstream from $\varepsilon-$, upstream from $\delta-$, and downstream from the $\beta$-globin gene. Interestingly, the three inverted pairs in the $\beta$ cluster are all arranged tail to tail, with about 800 bp of non-repetitive DNA between them. The Alu sequences that have attracted most interest are the inverted pair located $3 \mathrm{~kb}$ upstream from the $S$ gene because of the hypothesis that these had a role in regulation of the $\gamma$ to $\beta$ switch (see Section 8.2 ). The second major class of repeat sequence is known as the Kpn (or LI) family because of KpnI restriction endonuclease cleavage sites located at analogous positions in many copies of the sequences (68). Two copies lie downstream from the $\beta$-globin gene and another between the $\varepsilon$ - and $\gamma$-globin genes $(48,112)$. All three KpnI regions have been sequenced. The inter $E$ - $\gamma$ Aiu repeat that is over $6 \mathrm{~kb}$ in length has a strong homology with the retrovirus long-terminal repeat at the end near the $\gamma$-globin gene (113). Although RNA homologous to the human Kpn family is present in many human cells, its function and the nature of any protein that it might encode has not yet been established.

\section{HAEMOGLOBIN VARIANTS}

During the past 30 to 35 years the determination of the detailed chemical structures of the normal Hbs paralleled the discovery of hundreds of $\mathrm{Hb}$ variants. The classification of $\mathrm{Hb}$ variants presented here is based upon the gene anomalies; we thus distinguish $\gamma, \delta$, and $\beta$ variants of the $\beta$-globin gene cluster, and $\alpha$ variants of the $\alpha$-globin gene cluster. These variants can be subdivided into different groups of abnomalities, such 
as the unstable Hbs that often cause a mild-to-severe congenital haemolytic anaemia, variants with an increased affinity for oxygen, variants with a decreased affinity for oxygen, variants with special properties such as $H b S$, and variants without apparent change in functional and physicochemical properties. The severity of these disorders varies, and while some cause severe symptoms, others are associated with only mild symptoms or none at all.

The majority of abnormal Hbs are found in the heterozygous state, although several have been found in homozygotes. Precise diagnosis of each abnormal state is important for the management of the individual case. Only those variants that have been reported in the Surinam population are considered here.

6.1 B Chain Variants. At present there are neally 300 known $\beta$ chain variants; the great majority (95:) are single amino acid substitutions in the $\beta$ polypeptide chain. A few variants have amino acid replacements at two different sites on the same subunit (114). For example, Hb C-Harlem has a substitution as in $\mathrm{Hb} S[B 6(A 3) G l u \rightarrow V a l]$, and a substitution at position 73 [B73(E17)ASFASn] similar to $\mathrm{Hb}$ Korle-Bu. These variants arose by one of two mechanisms: new mutation on a variant gene or crossover between two variant genes. Other types of $\beta$ variants have deletions or insertions. The quantity of $\beta$ chain variants in heterozygote carriers usually varies between 25 to $45 \%$. This range can be attributed to a number of independent factors. The mutant mRNA could be transcribed, processed or transported less efficiently, or could be unstable or degraded rapidiy (115). In the case of $\mathrm{Hb} E[\beta 26(B 8) G l u-y$ Ls] and $\mathrm{Hb}$ Knossos [B27(B9)Alasser] the mutation causes a defect in mRNA processing (see section 7.3a) leading to thalassaemic phenotypes. The vast majority of $\beta$ gene variants are synthesized at a normal rate. The reduced amount of abnormal $\mathrm{Hb}$ in some cases appears to be due to increased catabolism of the variant $\mathrm{Hb}$ owing to abnormal subunit interactions, impaired haem binding, and decreased solubility.

In vitro experiments have shown that chain competition between normal $\beta$ chains $\left(\beta^{A}\right)$ and variant $\beta$ chains $\left(\beta^{X}\right)$ for $\beta$ chains is determined in part by the surface charge of the subunits (116). Variants such as $H b E$, with positively charged $\beta$ chains, assemble less readily than those with negatively charged $\beta$ chains such as $\mathrm{Hb} \mathrm{J}$-Baltimore (116a).

The presence of a concurrent $\alpha$-thal further reduces the amount of $\alpha_{2} \beta_{2}$ in the red cells of the positively charged $\beta$ variants $(117,118)$. In the case of $\mathrm{HD} J$-Baltimore the amount of $\beta X$ increased when $\alpha$-thal is present. There is no $\mathrm{Hb} A$ production in individuals with a compound heterozygosity for an abnormal $\beta$ chain and a $\beta^{\circ}$-thal. This condition is, therefore, almost indistinguishable from the homozygous $\beta^{X} / \beta^{X}$ condition, except from hypochromia, elevated $\mathrm{Hb} \mathrm{A}_{2}$ and high $\mathrm{Hb} F$ levels. Family studies and DNA analysis are often needed to establish a proper diagnosis in these cases. Hb $S$, $\mathrm{Hb} C$, and $\mathrm{Hb} E$ are the most common $\beta$ chain variants to occur in the Surinam population and they will be discussed further below.

6.1a Pathophysiology of the SS Disorder. Hb $S$ is the result of a single mutation of one nucleic acid within codon 6 (GAG) GT6); it results in the replacement of a valine for a glutamic acid residue (54). Hb $S$ $\left(\alpha 2 \beta 2^{S}\right)$ functions normally in the oxygenated state, but polymerizes in the 
deoxygenated state. This polymerization of $\mathrm{Hb} S$ causes the red cell to be sickle-shaped. Sickling can be reversed by reoxygenation (119). The process of sickling and unsickling will ultimately lead to damage of the red cell membrane, preventing the red cell from returning to a normal shape after sickling. Such irreversible sickled cells (ISCS) are prematurely destroyed by the reticulo-endothelial system, leading to chronic haemolysis (119). The impaired red cells may become lodged in the microcirculation and initiate a sickle cell crisis due to subsequent vaso-occlusion (119). Fig. 1.9 lists the various clinical aspects of sickle cell anaemia. The vaso-occlusive crises or painful crises are characteristic of sickle cell disease. The sickling process is temperature-, $\mathrm{pH}-$, and concentrationdependent. Sickling will occur when a critical deoxyHb $S$ concentration has been reached in the cell, or when a low $\mathrm{pH}$ or a high temperature is present. Sickling is prevented by conditions that lower the intracellular $\mathrm{Hb} S$ concentration levels in the cell, e.g. extracellular hypo-osmolality, iron deficiency, and the coinheritance of an $\alpha$-thal. Numerous other factors are involved in initiating sickling, such as cell age, osmotic pressure, sluggish flow, vascular damage, structure of the microcirculation, infection, pregnancy, and hypotension (119-122). X-ray analysis has shown the importance of the $\$ 121$ Glu position in the crystallized Hb $S$ polymer. The simultaneous presence of Hb D-Punjab [B121(GH4)Glu-OSln] and Hb O-Arab [B121 (GH4)Glu-x,ys] promotes the sickling tendency, emphasizing the importance of the B121 Glu interaction in the sickling process $(123,124)$.

The sickling process is inhibited by the presence of $\mathrm{Hb} D$ due to the formation of an asymmetrical hybrid $\alpha 2 B^{S} \gamma(125,126)$. This result indicates that SS patients with considerable amounts of $\mathrm{Hb} F$ are less prone to sickling crises. Indeed, this has been confirmed for carriers of the $\beta^{S}$ gene with a specific Saudi Arabian haplotype in which the level of $H b F$ is approximately $30 \%$ (127). The cause of the increased Hb F production is not known but a deletional HPFH is excluded in these cases. Based upon the above observations, reactivation of the developmentally repressed $\gamma$-globin genes has been approached as a therapeutic goal for treatment of patients with severe sickle cell anaemia. Drugs such as 5-azacytidine, hydroxyurea, and erythropoietin that increase $H \mathrm{H} F$ synthesis in the red cells, are currently under investigation $(128,129)$.

6.1b Sickle Cell Trait (AS). Sickle cell trait appears to be a benign condition. However, there are some reports indicating that some complications can occur (130). Splenic infarction during high altitude flight in non-pressurized aircraft has been reported; haematuria without any other cause occurs occasionally and is a more frequent finding than in normal (AA) subjects. Such haematuria is due to a set of local circumstances within the kidney that predisposes to in vivo sickling. Barbotin and Duclof showed that $25 \%$ of their hospital patients with AS in Dakar (Senegal) had recurrent symptoms, including abdominal pains, pains in the distal joints, and froto-parietal headaches (131).

6.1c Geographical Origin of $\mathrm{Hb} S$. According to older theories, the $\beta^{S}$ gene arose on the Arabic peninsula, from where it spread by trade connections to Africa, the Mediterranean, and India. The slave trade introduced $H \mathrm{H} S$ to the Americas. Migration waves from the former colonies introduced the gene to Western Europe. 
HB S [2 2\$26(A3)GLUFVAL]

deoxygenation of tissues

$\downarrow$

Formation of Filaments and Fibers of Hb S Molecules Inside Red Cells

1

distortion of red cell membrane with increased rigidity of red cells

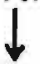

\&
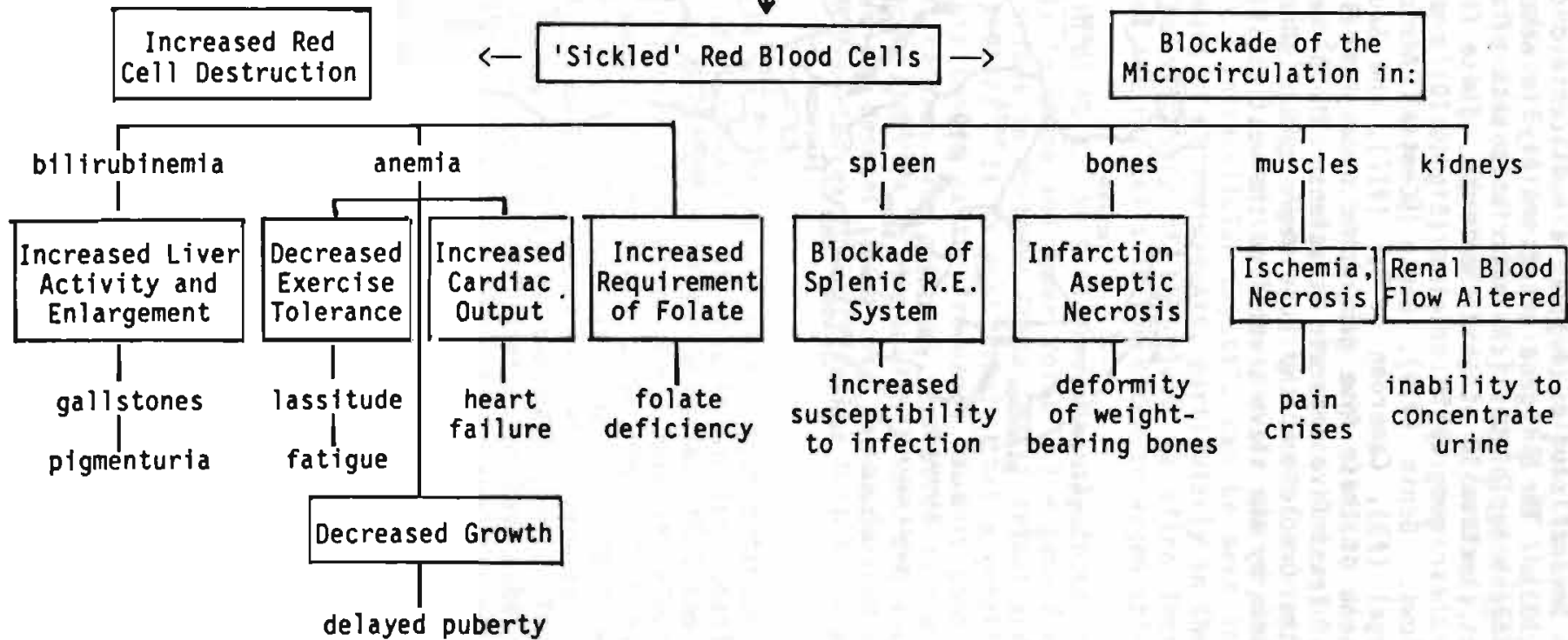

FI6. 1.9 Scheme fllustrating the various clinical aspects of sickle cell anaemia. 
Several studies suggest a multicentric origin for the $B^{S}$ gene (127, 132,133). The $\beta^{S}$ gene occurs mainly in association with five distinctiy different haplotypes [characteristic sets of alleles at linked polymorphic sites (section 10 of this chapter)]. These five haplotypes have been named for their geographic origins (Fig. 1.10) and have also been numbered as follows: Benin (\$19), Bantu (Central African Republic or CAR) (\$20), Senegal (\$3), Cameroon or Ar (\$17), and Saudi Arabian/Indian (\$31). In any one of these five geographic areas, the $\beta^{S}$ gene has arisen by mutation on at least five separate occasions. The $\beta^{S}$ gene in Surinam is found mainly in the Creole and the Bush Negro group, whose ancestors were brought to Surinam by the slave trade from the west coast of Africa (see Chapter 4 ).

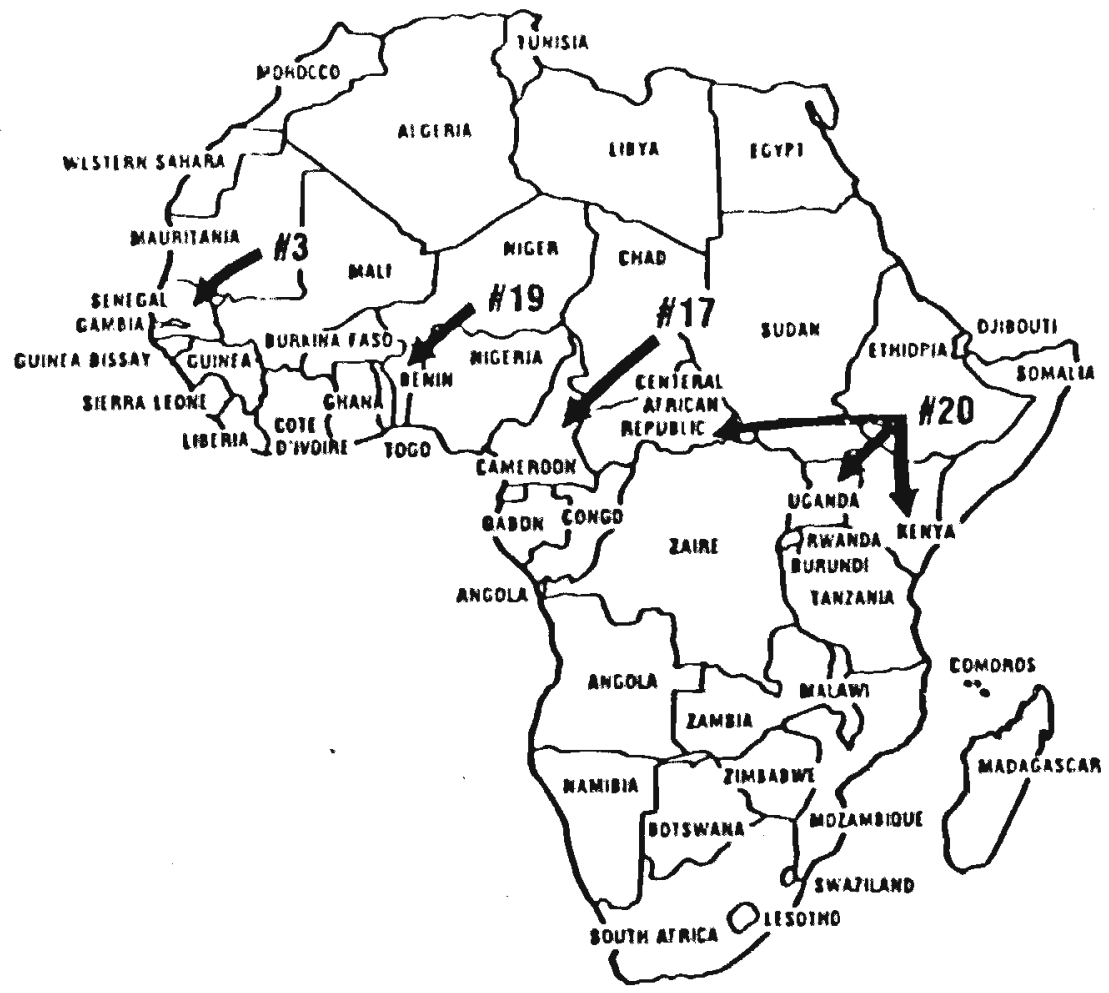

FI6. 1.10 The geographical origin of $\beta^{5}$ chromosomes with distinct haplotypes in Africa. Haplotype 31 is found exclusively in Saudi Arabia and India.

Occasionally, Hb $S$ is observed among Hindus in Surinam; the haplotype of these cases, however, has not been determined (134). No Hb $S$ was found in a previous study among the Trio and Wayana natives living in southern Surinam (135). Isolated cases of $\mathrm{Hb} S$ among natives living in the Surinam Savannah belt has been reported but were ascribed to admixtures with Negroes (136). 
6.2 Hb C Disonders. Hb C is characterized by a substitution of glutamic acid by lysine at position 6 of the $\beta$ chain. This is the result of a G.A mutation at the first position of codon 6 of the $\beta$ gene (GAGAAG). The substitution gives $H b C$ a high positive charge. Accordingly, it has a slow mobility in alkaline electrophoresis. In IEF it moves at the same position as $\mathrm{Hb} \mathrm{A}_{2}$ and $\mathrm{Hb} \mathrm{E}$ (see Chapter 2).

$\mathrm{Hb} C$ heterozygosity is not associated with any clinical disability $(137,138)$. Stained films of $A C$ blood show an increased number of target cells and an increased density (139). Homozygosity for Hb C causes a mild haemolytic anaemia ( $\mathrm{Hb} 8-10 \mathrm{~g} / \mathrm{dl})$, and the life-span of the erythrocytes is somewhat shortened (140). Intracellular crystals can be seen in small numbers in routine blood smears of $C C$ individuals, particularly in the dense microspherocytes (141). The viscosity of the blood is often increased, which may cause a trapping of the red cells in the often enlarged spleen.

6.2a Geographical Origin of $H b C$. Hb $C$ is predominantly found in areas of West Africa, particularly in Ghana and Upper Volta. The gene frequency approaches 0.15 in certain tribes in Northern Ghana (Mossi tribe) and Upper Volta (Boukina Fasso tribe) (142). It is most likely that a genetic flow has occurred from around this centre as the frequency of this gene diminishes rapidly away from this centre. The gene was introduced in the Caribbean, North America, and South America by the slave trade, and recently, by migration of people of African descent to Europe. In the Surinam population the $\mathrm{HB} C$ gene has been reported exclusively in the Bush Negro and the Creole group $(134,143-145)$.

6.3 Hb $E$ Disorders. $H b E$ is the result of a single mutation of one nucleic acid within codon 26 (GAGPAAG). It results in the substitution of glutamic acid by lysine at position 26 of the $\beta$ chain. Hb $E$ comigrates with $\mathrm{Hb} \mathrm{A}_{2}$ and $\mathrm{Hb} C$ on cellulose acetate at $\mathrm{pH} 8.6$. However, electrophoresis in citrate agar at $\mathrm{pH} 6.0$ can separate these Hbs. Hb $E$ migrates toward the cathode with a mobility similar to that of $\mathrm{Hb} A$ and $\mathrm{Hb} D$, whereas $H b C$ moves toward the anode. $H b E$ is synthesized at a reduced rate in reticulocytes due to a decreased stability of the mRNA (146). Thus, the $\mathrm{Hb} \mathrm{E}$ structural gene may be viewed as a $\beta^{+}$-thal gene. The base substitution at codon 26 creates a new splicing sequence that causes abnormal mRNA processing as well as instability of the mRNA during erythroid maturation. $\mathrm{Hb} \mathrm{E}$ heterozygotes are asymptomatic; the $\mathrm{Hb}$ levels are normal but the red cells are microcytic.

6.3a Geographical Origin of $H b E$. Hb $E$ is primarily found in Southeast Asia. However, it has been reported in Blacks $(147,148)$ and Cauçasians (134), and there is convincing evidence that the $\beta^{E}$ gene, 1ike the $\beta^{5}$ gene, has arisen independently on a number of occasions (149). Because of the immigration of people from Southeast Asia to different parts of the world, it is encountered quite commonly in Surinam, the United States, and Europe. In Surinam, $H b$ is primarily found in the Javanese population.

$6.4 \mathrm{Hb} A_{2}$ Variants. At present, the number of discovered $\delta$ chain variants is only 20 their substitutions are listed in the 1991 issue of the International Hemoglobin Information Center variant list (114). This number is relatively small because of difficulties in identifying amino acid substitutions in a protein that occurs in low quantities (1 to $1.5 \%$ ) 
in heterozygotes, and in slightly higher quantities (2 to $3 \%$ ) in heterozygotes who have a concomitant $\beta$-thal trait. The most common $\mathrm{Hb} \mathrm{A}_{2}$ variant in Surinam is $\mathrm{Hb} \mathrm{A}_{2}{ }^{\prime}$ or $\mathrm{Hb} \mathrm{B} \mathrm{B}_{2} \mathrm{~W}_{2} \mathrm{~S}_{2} 16(\mathrm{A13}) \mathrm{Gly} \rightarrow \mathrm{Arg}$ ] and found among Creoles and Bush Negroes $(134,150,151)$. Hb $B_{2}$ results from a single mutation at codon $16(G G C \rightarrow C G C)$, a substitution of glycine for arginine at position 16 of the $\delta$ chain. This variant can be identified by routine Hb electrophoresis. Both $\mathrm{Hb} \mathrm{B}_{2}$ heterozygotes and homozygotes are asymptomatic. With the development of amplification procedures of segments of ONA (144) and the availability of simple DNA sequence analysis (152), a new approach has become available for the identification of these variants using only small quantities of blood (160) and that is as reliable as classic amino acid sequencing, but less labour-intensive and, therefore, should be useful in detecting new $\delta$ chain variants.

$6.5 \alpha$ Chain Variants. At present there are $161 \alpha$-globin structural variants that have been described (114). These variants result primarily from single amino acid substitutions. The mutation of one of the four $\alpha$ genes will result in about 5-25\% of the variant $H b X\left(\alpha^{2} 2 B_{2}\right)$ in the heterozygote $(154,155)$. The relative level of abnomal $\alpha-g i \delta b i n$ genes varies according to the degree in which the affected gene normally contributes to $\alpha$-globin synthesis $(155,156)$. As mentioned earlier in this chapter, the $\alpha 2$ gene encodes more protein than the $\alpha 1$ gene, due to a 2.6 to 1 ratio of $\alpha 2: \alpha 1$ mRNA levels (157). Structural mutants at the $\alpha 2$ locus can be expressed at higher levels due to the dominant role of the $\alpha 2$ gene in the $\alpha$-globin expression (155). The presence of a concurrent $\alpha$-thal increases the amount of $\alpha X_{2} \hat{P}_{2}$ in the red cell $(30-35 \%)$, while in individuals with an unstable $\alpha$ chain variant, there is a reduction of a variant $(5-10 \%)$. Several $\alpha$ chain variants are located on the $\alpha$-thal-2 chromosomes $\left(-\alpha^{3.7} \mathrm{~kb}\right.$ or $-\alpha 4.2 \mathrm{~kb})$. The most common is $\mathrm{Hb}$ G-Philadelphia $\alpha 68$ (E17)Asn $>$ Lys] occur ring primarily in Black populations $(158,160)$ that is encoded at a $-\alpha^{3.7}$ locus. The G-Philadelphia mutation can also occur on a normal chromosome $(\alpha \alpha)$ and is then expressed at $20-25 \%(161,162)$.

Individuals who carry an $\alpha$-thal-1 (-) gene in trans to an unstable $\alpha$ chain variant $\left(--/-\alpha^{x}\right)$ have a severe form of $\alpha-\overline{t h a} \overline{(H b} H$ disease; see Section $7.1 \mathrm{a})$, that results in moderate to severe anaemia $(162,163)$.

$\mathrm{Hb} J$-Meerut is the only $\alpha$ chain variant reported so far in the Surinam population (134).

6.6 Chain Variants. $\gamma$ Chain variants are the result of substitutions in the Gr or A $\gamma$ chains. Sixty-two $\gamma$ chain variants have been described so far (114). The relatively small number of $\gamma$ chain variants is due in part to the fact that $H b F$ is barely detectable after the first six months of life. In addition, large scale surveys of cord blood samples have only been initiated during the past few years. No functional significance has been ascribed to any of the $\gamma$ chain variants that have been reported with the exception of $\mathrm{Hb}$ F-Poole $\left[\mathcal{X}_{2} \mathrm{G}_{2} 130\right.$ (H8)Trp-G1y], an unstable fetal $\mathrm{Hb}$ causing haemolytic anaemia in the neonatal period (164), and $\mathrm{Hb} F$ M-Osaka $\left[\alpha_{2}{ }_{\gamma_{2}} 63\right.$ (E7) His $\left.{ }^{T y r}\right]$, that causes neonatal cyanosis $(165)$ Hb FSardinia is encountered in many populations (166-168). In this Ar chain variant, the isoleucyl amino acid is substituted by threonine at position 75. Carriers of this variant are clinically asymptomatic. 
The thalassaemias constitute a heterogenous group of inherited disorders, characterized by abnormal gene function resulting in the total absence or quantitative reduction of $\alpha$ - or $\beta$-globin chain synthesis in human erythroid cells. Thalassaemias are classified according to the type of

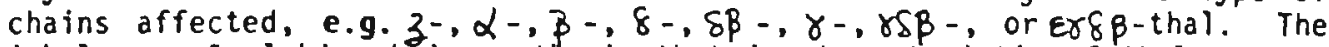
imbalance of globin chain synthesis that is characteristic of thalassaemia results in an excess of $\alpha$ or $\beta$ chains. The excess chains tend to precipitate in the red cell precursors leading to premature removal of surviving red cells by the spleen.

$7.1 \alpha$-Thal. The $\alpha$-thalassaemias are probably the most prevalent and most widely distributed disorders of $\mathrm{Hb}$ synthesis. In the foetus, a reduced synthesis in the $\alpha$ chains results in an excess production of $\gamma$ chains. These excess $\gamma$ chains will form Hb Bart's ( $\left.\gamma_{4}\right)$ that is easily detectable by electrophoresis. Severely affected individuals might be identified during adulthood by the production of $\mathrm{Hb} \mathrm{H}\left(\$_{4}\right)$ that readily forms inclusion bodies in the red cells. Several authors have shown a reasonably good correlation between the level of Hb Bart's, the red cell morphology and indices, and the existence of $\alpha$-thal conditions in the neonatal period $(169-171)$.

7.1a Classification of the $\alpha$-Thalassaemias. The $\alpha$-thalassaemias are caused by deletion (the deletional types) or mutations (nondeletional types) of (or in) one to four of the $\alpha$ genes (170). The resulting disorders involve various degrees of imbalance between $\alpha$ and $\beta$ chain synthesis, and patients can be classified using haematological, biochemical, and molecular criteria.

Fig. 1.11 shows the $\alpha-1 i k e$ globin gene cluster. The $\alpha 2 \alpha$ and $z$ genes are the functional $\alpha$-globin genes. As shown in Fig. 1.11 the two $\alpha$-globin genes are embedded in a large region of homology that is divided by short divergent regions into three homology subsegments: $X, Y$, and $Z$ (172). Non-homologous crossover between these homologous segments are responsible for the most common forms of $\alpha$-thal. The crossover can occur between the two $X$ regions or the two $Z$ regions, resulting in the so-called "leftward) $\alpha$-thal-2 genotype $\left(-\alpha^{4.2}\right)$ and the "rightward" $\alpha$-thal-2 genotype $\left(-\alpha^{3.7}\right)$. The $-3.7 \mathrm{~kb}$ deletion can be further subdivided into types I, II, and III, based on the exact position of the crossover within the $Z$ box $(173,174)$. The $-3.7 \mathrm{~kb}$ deletion is found in Mediterranean populations and is the principal $\alpha$-thal allele in Black and Asian populations. The $-4.2 \mathrm{~kb}$ deletion has been observed in Asian populations. Fig. 1.12 shows that these crossover events can create triplications on the opposite chromosome; the anti-3.7 $\mathrm{kb}$ triplication $(\alpha d \alpha+3.7)$ and the anti-4.2 kb triplication (dod +4.2$)$. Although there is a mild excess of $\alpha-m R N A$, the $\alpha$ and $\beta$ chain synthesis is essentially balanced, and individuals with a total of five $\alpha$ genes are clinically and haematologically normal $(175,176)$.

In addition to the frequent $-\alpha^{3.7}$ and $-\alpha^{4.2}$ deletions, several deletions have been described involving both $\alpha$-globin genes, thus leading to the $\alpha$-thal-1 condition (--) $(177-179)$. These deletions range in size from rather small $(5.2 \mathrm{~kb})$ to those that remove the entire cluster (summarized in Fig. 1.11). The two most common deletions ( - SEA) and (-AED), occur 


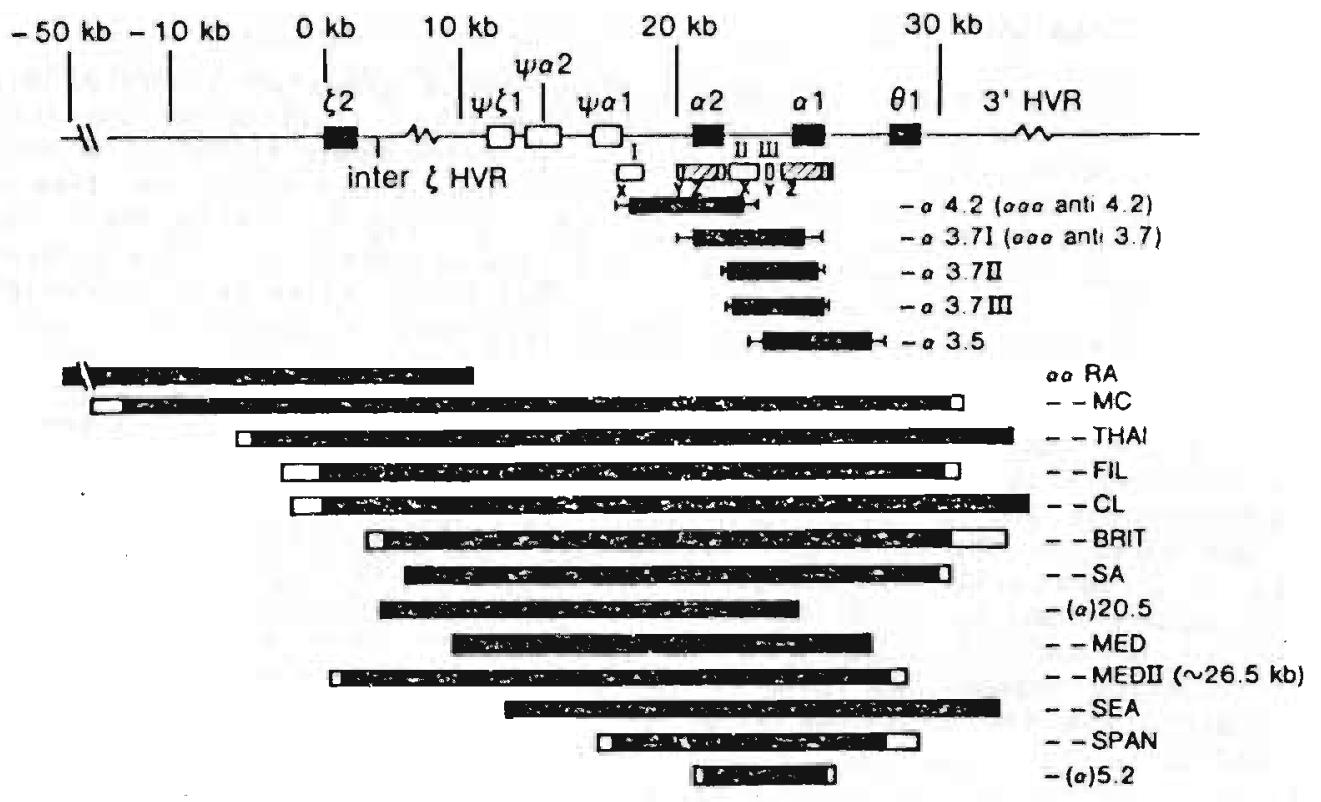

FI6. 1.11 A summary of major deletions in the $\alpha$-globin gene cluster that result in the loss of expression of both $\alpha-g l o b i n$ genes (kindly provided by Dr. D.R. Higgs, Oxford, England). Deletions which remove both $\alpha$-globin genes are denoted as -, those in which the deletion leaves part of the $\alpha$-globin gene intact is denoted as $-(\alpha)[(-\alpha) 20.5$ and $(-\alpha) 5.2]$, and those in which both $\alpha$-globin genes remain fully intact (although their expression is either severely reduced. or abolished) are denoted as $\alpha \alpha(\alpha R A)$.

in the Southeast Asian and the Mediterranean populations, respectively. of special interest is the $\alpha \alpha^{R A}$ deletion in which the two $\alpha-g$ lobin genes are intact but the $z$ and 43 genes are removed (179). This deletion biocks $\alpha$-globin gene expression in cis to the deletion, and study of this deletion is very helpful in identifying regions critical for $\alpha$-globin gene expression as is shown for similar deletions within the $\$-$ globin gene cluster (106). $\alpha$-Thal-1 trait closely resembles the $\alpha$-thal- 2 homozygosity, in which one of the $\alpha$-globin genes on each chromosome is deleted, $-\alpha /-\alpha$ or $-\alpha / \alpha-$ or $\alpha-/ \alpha-$. Individuals with either one of these conditions have a mild anaemia with microcytosis $(180,181)$.

A more severe form of $\alpha$-thal is $H b H$ disease in which there is only one functional $\alpha-g l o b i n$ gene. This syndrome occurs most commonly in Southeast Asia and the Mediterranean basin. The loss of normal $\alpha 2$ gene function in trans to the $\alpha-$ thal-1 gene appears to give a clinically more severe type $\overline{\mathrm{of}} \mathrm{Hb}$ disease than that of the $\alpha \mathrm{l}$ gene, emphasizing the greater influence of a thalassaemic mutation on the $\alpha 2$ locus. Hb $H$ disease leads to severe 


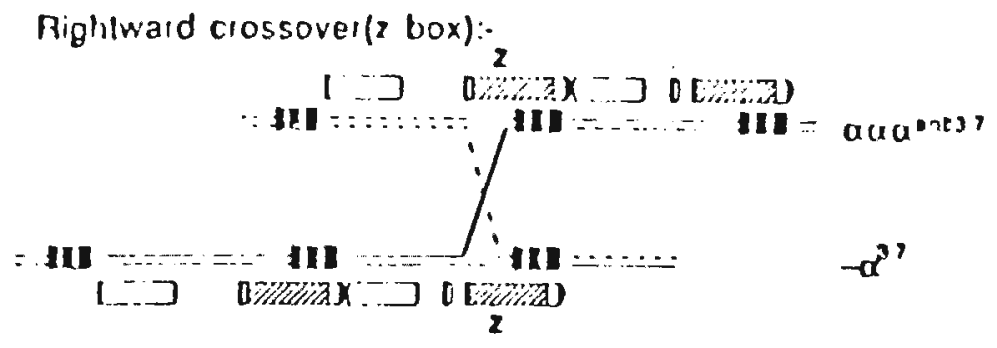

Lellward crossover(x box):-

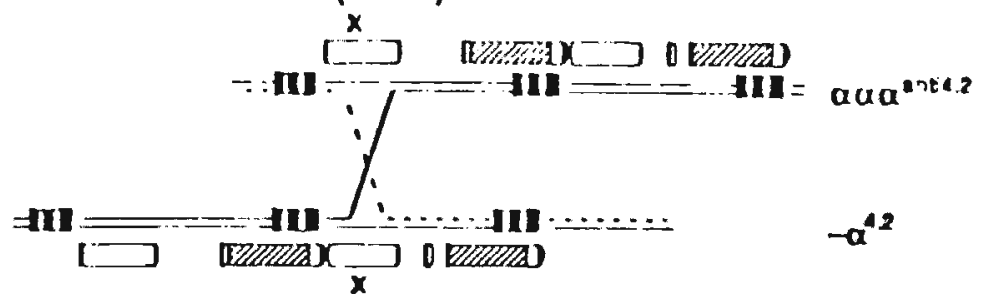

FI6. 1.12 Crossover events between the $z$ boxes resulting in the rightward $-\alpha^{3.7}$ or triplicated $\alpha \alpha \alpha$ ant $i 3.7$, and between the $x$ boxes leading to the leftward $-\alpha^{4.2}$ or triplicated $\alpha \alpha \alpha$ anti 4.2 deletions.

$\alpha$ chain deficiency, that in turn results in excess $\beta$ chain accumulation in the form of the tetrameric $\mathrm{Hb} \mathrm{H}$. Patients with $\mathrm{Hb} \mathrm{H}$ disease have a mild to moderate with sometimes severe haemolytic anaemia $(187,188)$.

The most severe form of $\alpha$-thal is the $\alpha$-thal-1 homozygosity or $H b$ Bart's hydrops foetalis with no functional $\alpha$-globin genes, $--1--(186)$. This condition is not compatible with life; all foetuses are hydropic stillborn or die shortly after birth (194-196).

Several forms of nondeletional $\alpha$-thal have been identified (1isted in Table 1.1). Such nondeletional $\alpha$-thal alleles have been observed in Asian, Mediterranean, Black, and Saudi Arabian populations (189). These nondeletional mutations are found in both normal $\alpha$-globin genes and in the frequently occurring $-\alpha \beta$ hybrid gene. Unexpectedly, the nondeletional $\alpha$-thal mutations are asymmetrically distributed between the two $\alpha$-globin loci, compared with the more symetrical distribution of the $\alpha$ variants. This unequal distribution is most likely due to a bias occurring because of the dominant role of the $\alpha 2$ gene in $\alpha$-globin expression. Individuals with $\alpha 2$ mutations would, therefore, be more readily recognized and studied.

7.2 The $\beta$-Thalassaemias. $\beta$-Thal is an extremely heterogeneous group of disorders of $\mathrm{Hb}$ synthesis, and is due to a decrease or absence of $\beta-g 10-$ bin chain synthesis (47). It has been divided into two types: $\beta$ - and $\beta^{+}$-thal. In homozygous $\beta^{\circ}$-thal, the $\beta$ chains are present for some $5-30 \%$ of normal levels. There is a proportional deficiency of $\$-m R N A$ in erythroid cells of affected individuals (47). More than 100 different $\beta$-thal genes have been identified $(190,191)$. The heterozygous carriers can be identified by an elevated $\mathrm{Hb} \mathrm{A}_{2}$ level (range 3.5-8\%), marked microcytosis (MCV $<70 \mathrm{fl}$ ), 


\section{RNA Processing}
$\alpha 2$
$\alpha 2$
IVS-I donor site
Poly A signal

Mediterranean Middle Eastern; Mediterranean

RNA Translation
$\alpha 2$
$\alpha 1$
$-\alpha^{3} .7$
$-\alpha^{3.7}$

\section{CCACCATGG $\rightarrow$ CCACCACGG \\ CCACCATGG $\rightarrow$ CCACCGTGG \\ CCACATGG $\rightarrow$ CCACCGTGG \\ CCACCATGG $\rightarrow$ CC-CATG6}

$\begin{array}{ll}\alpha 2 & \text { Exon } 3 \\ \alpha 2 & \text { Termination codon } \\ \alpha 2 & \text { Termination codon } \\ \alpha 2 & \text { Termination codon } \\ \alpha 2 & \text { Termination codon } \\ -\alpha 3.7 & \text { Exon 1 }\end{array}$

Unstable Protein

$\begin{array}{ll}\alpha 2 & \text { Exon 3 } \\ \alpha 2 & \text { Exon 3 } \\ \alpha & \text { Exon 3 } \\ -\alpha 3.7 & \text { Exon 1 }\end{array}$

\section{$\alpha 116$ GAC $\rightarrow$ UAG \\ $\alpha 142$ TAAXCAA \\ $\alpha 142$ TAA $\ A A$ \\ $\alpha 142$ TAA $\rightarrow$ TCA \\ $\alpha 142$ TAA> $\triangle A A$ \\ $\alpha 30 / 31$ GAGAGG $>$ GAG- 6}

Mediterranean Mediterranean Black

North African; Mediterranean

Black

Southeast Asian Mediterranean Indian Black Black

hypochromia (MCH $<25 \mathrm{pg}$ ), and slight anaemia (192). In about half of these cases $H b F$ is slightly increased (1-3\%). Most individuals with homozygous 3-thal manifest a chronic severe microcytic haemolytic anaemia and hepatosplenomegaly, and may have a characteristic facies due to bony distortion from expansion of the marrow. Treatment is mainly by repeated blood transfusions that relieves the chronic anaemia and prevents bony changes, combined with iron chelation therapy to remove the excess iron from the circulation. Bone marrow transplantation, of which about 1000 have been performed, is a new method that has recently been approached for therapeutic purposes (193-197).

At the molecular level, 3 -thal is due to deletions of part or all of the $\beta$-globin gene (deletional types), or more of ten to point mutations that include single base changes, and deletions and insertions of one to four nts (nondeletional types). These mutations can affect transcription of the $\beta$-globin gene, or affect the processing and translation of the $\beta$-globin mRNA. 


\section{3 classification of $\beta$-Thal.}

7.3a Nondeletional Types; mRNA Processing Mutants. The globin system appears to provide a good example for the requirement of splicing of RNA prior to transport into the cytoplasm. The analysis of these globin genes has been remarkably helpful in providing detailed insights about the RNA sequences required for specific selective and effective RNA splicing. Almost $50 \%$ of the naturally occurring point mutations producing $\beta$-thal have been shown to affect mRNA splicing (146).

The GT dinucleotide $5^{\prime}$ of the intron and the dinucleotide A6 3' $^{\prime}$ of the intron are known to be invariant in animal cells (198). This is defined as the consensus splice rule by Breathnach and Chambon (199). Mutations in these invariant nts result in complete splicing failure and cause $\beta^{\circ}$-thal (191). A comparison of more than a hundred splice junction sequences has provided the expanded consensus splice junction sequences shown in Fig. 1.13. The splice junction consensus sequences appear to be involved in the formation of a base paired structure between U1 RNA and the precursor mRNA $(199,200)$. Ul RNA is a small, stable, nuclear RNA species that may function as a cofactor in the splicing reaction. Adjacent portions of the $5^{\prime}$ end of U1 RNA are complementary to the $5^{\prime}$ and $3^{\prime}$ 'splice junction sequences; by forming a base paired structure with U1 sequences, the $5^{\prime}$ and $3^{\prime}$ ends of an intron are juxtaposed in a way that could readily facilitate accurate splicing (201). Mutations in the consensus splice sites affect normal splicing, mostly leading to decreased splicing of mRNA, and of ten, milder forms of 3 -thal. In all cases of altered splice function, as mentioned above, the mutations lead to activation of cryptic (alternative) splice sites that are normally nonfunctional, and located in proximity to the normal splice sites (201-203). For example, inactivation of the $5^{\prime}$ splice site of the first exon of the human $\beta$-globin gene by a base change of the first $n t$ of intron 1 (IVS-I) leads to the utilization of GT dinucleotides at positions 105 and 127 of exon 1 and IVS-I position 13 as 5 ' splice sites (Fig. 1.13).

\section{5' SPLICE SITES}

Consensus 5' splice sequence

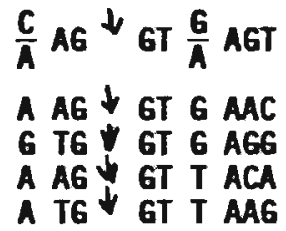

Human $\beta$ Exon 1 residue 105

Exon 1 residue 127

IVS-I residue 13

IVS-II residue 48

3' SPLICE SITES

Consensus $3^{\prime}$ splice sequene

YYYYYYKCA $\downarrow_{\frac{6}{T}}^{6}$

Human BIVS-II residue 579

ITCTTCAG $\downarrow_{\text {GG }}$

FI6. 1.13 Cryptic Splice Sites in Human Genes. The splice sites shown are those used when a mutation inactivates the nearest normal splice site. 
Mutations in the IVS-II region are also responsible for creating new splice sites $(206,207)$. The base change $G 76$ at IVS-II-745 creates a new $5^{\prime}$ splice site (Fig. 1.14). This new splice site is jolned to the normal $3^{\prime}$ splice site of IVS-II, and the normal $5^{\prime}$ splice site of IVS-II is joined to a cryptic $3^{\prime}$ splice site at position 579 (Fig. 1.13) creating a new exon. In this case, however, a low level of precursor mRNA molecules is processed normally.

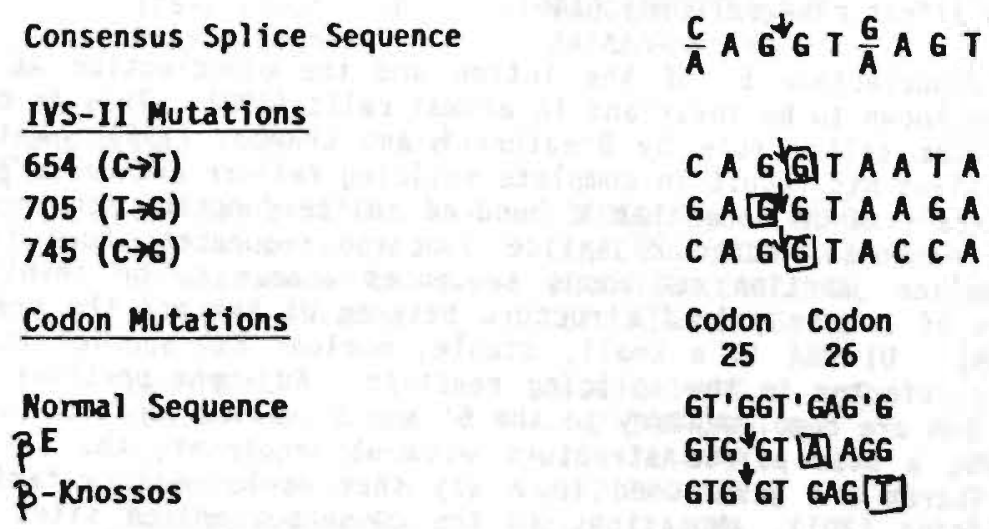

FI6. 1.14 Thalassaemia mutations creating new $5^{\prime}$ splice sites. The boxed sequences are sites where the single base substitution has generated new splice site in the globin gene.

The mutations at IVS-II-654 (G)T) and IVS-II-705 (F>G) also lead to the activation of the previously mentioned cryptic acceptor site in IVS-II-579, however, in these cases no normal splicing of IVS-II sequences from precursor mRNA are transcribed leading to a $\beta^{\circ}$ phenotype.

Single base changes in the exons of the globin gene can also create new splice sites $(208-210)$. This has been observed to occur with base changes in the coding region of the first exon (Fig. 1.14), e.g. Hb E, Hb Knossos, codon $24(A \rightarrow T)$, and $\mathrm{Hb}$ Malay [B19(B1)Asn>Ser]. Hb Malay is the result of a single mutation at codon 19 (AAC AGC) that activates the cryptic splice site at codons 17,18 , and 19 (211). The three other mutations increase the homology of the cryptic splice site at codons $24,25,26$, and 27 with the donor consensus junction sequences, therefore producing abnormally spliced mRNA.

In all the cases mentioned above, the incorrectly processed mRNA will contain intron remnants that affect its intranuclear stability or nucleocytoplasmic transport, presumably due to the presence of in phase terminating codons.

7.3b Frameshift and Nonsense Mutations. Frameshift mutations are deletions or insertions of one to four nts in the $\beta$-globin gene, that results in a shift in the reading frame and a complete alteration of the sequence; a termination codon will usually be present rather close to the frameshift (212). Nonsense mutations are caused by a single base substitution-in a 
normal codon that creates a premature termination of translation by producing a premature stop codon in the reading frame $(213,214)$. In both the frameshift and the nonsense mutations, shorter abnormal polypeptides are formed that are rapidly hydrolyzed in the red cell precursors. There is also a decreased amount of the mutated 3 -globin mRNA in the erythroid cells (215-217). Studies of the codon $39 \mathrm{C} \rightarrow \mathrm{T}$ mutation have shown that the decreased levels of $\beta-39$ mRNA are not due to a decreased cytoplasmic stability but rather to inhibition of the nuclear to cytoplasmic transport $(218,214)$. Both frameshift and nonsense mutations lead to the production of nonfunctional $m R N A$ and result in a $\beta^{\circ}$ type of thalassaemia.

7.3c Transcriptional Mutations. These mutations are located in the regulatory region $5^{\prime}$ to the $\beta$-globin gene cluster that controls transcription. The transcriptional mutation sites are located in the TATA box and in the proximal and distal CACCC boxes (Fig. 1.5). Six mutations have been found so far in the TATA box (191) that decrease the production of B-mRNA transcripts to $10-25 \%$ of normal. Five mutations are reported in the distal CACCC box with a mild $\beta$-thal gene found in the Black populations. Heterozygotes with mutations in the distal CACCC box and the Cap site have normal haematology, and normal $\mathrm{Hb} \mathrm{A}_{2}$ and $\mathrm{Hb} F$ levels, implying that these mutations cause the silent type of $\beta$-thal (219). No mutation has so far been reported for the CCAAT box. Recently, a new mutation at position +22 to the Cap site was discovered $(220)$. This mutation reduces $\beta-g l o b i n$ production either by affecting transcription or by affecting the $5^{\circ}$ capping process, that in turn may decrease mRNA stability or its ability to initiate efficient translation.

7.3d Poly A Mutations. These mutations, located $3^{\prime}$ to the $\beta$ gene, interfere with mRNA cleavage and lead to a reduced quantity of mRNA producing mild types of $\beta^{+}$-thal. Five mutations have been detected so far. The mutations are located in the AATAMA poly A signal (191). For the BC mutation (AATAMA $\rightarrow$ AACAAA), that is found in American Blacks, it was shown that the normal RNA cleavage was significantly reduced, and that a 900 bp longer transcript extended $3^{\prime}$ from the poly A site (221).

7.4 Deletional Types of $\beta$-Thal. Although most types of $\beta$-thal are caused by single nt mutations or by frameshifts, quite a few types are the result of larger deletions affecting the $\beta$-globin gene while leaving the other genes from the $\beta$ cluster intact. The deletions are considered to be caused by non-homologous breakage and reunion.

All deletional types of $\beta$-thal are $\beta^{\circ}$-thal due to the fact that mRNA synthesis is abolished or nonfunctional. The most common deletional $\beta$-thal observed is the 619 bp deletion that occurs as the second most prevalent deletion in the Asian population (222). The 619 bp deletion starts within the IVS-II and extends in the $3^{\prime}$ direction 209 nts past the termination codon.

Several deletions are associated with relatively high $\mathrm{Hb} \mathrm{A}_{2}$ levels in the heterozygote, ranging from 7.1 to $9.6 \%$. All these deletions remove sequences $5^{\prime}$ to the $\beta$-globin gene, including the promoter elements. They include: a) the Black American type with a $1393 \mathrm{bp}$ deletion involving the region -484 bp to the Cap site to IVS-II-415 (227); b) The Turkish 290 bp deletion extending from -125 bp to the Cap site up to nts 23,24 , or 25 
of the 3 -IVS-1 (224); c) the czechoslovakian 4237 bp deletion extending from $3.3 \mathrm{~kb} 5^{\prime}$ to the $3-g l o b i n$ gene Cap site to the middle of $\beta$-IVS-II (225). Four small deletions ranging from 7 bp to 44 bp have been identified $(223,226-228)$.

\section{SP-THALASSAEMIA}

The $8 \beta$-thalassaemias are associated with extensive deletions of varying lengths involving the $\delta$, the $\beta$, and often, one of the $\gamma$ genes (Fig. 1.15). They are characterized by a normal Hb $A_{2}$ level, a markedly raised $\mathrm{Hb} F$ level, and varying degrees of anaemia in the heterozygous state (229). In the homozygous state of the $\delta \beta$-thal there is a complete absence of $\mathrm{Hb}_{2}$ and $\mathrm{Hb} A$; the red cells of the patients contain $100 \%$ foetal $\mathrm{Hb}$ with thalassaemic phenotypes such as hypochromia and microcytosis. The patients are mildly anaemic in the heterozygous state with an increase in $\mathrm{Hb} F$ of $5-15 \%$ that is heterogeneously distributed. Most of the deletions resulting in \&p-thal are simple deletions, but a complex rearrangement in Asian Indians is characterized by both a deletion and an inversion (230). Based upon gene mapping studies, $\delta \beta-$ thal can be divided into two distinct groups: a) the $G_{\gamma} A_{\gamma}$ type or $(8 \beta)^{\circ}$-thal in which the $H b F$ contains both $G_{\gamma}$ and $A \gamma$, and b) the $G_{\gamma}$ type or $G_{\gamma}+\left(A_{\delta} \beta B\right)^{\circ}$-thal in which there is only production of $G_{\gamma}$ chains. The deletion breakpoints of several of the $8 \beta$-thal have been characterized (112). Henthorn et al (112) showed that deletion breakpoints are more likely to occur within transcriptional units of the $\mathbb{Z}$-globin gene region than would be expected by chance. All of the so far characterized $8 \beta$ types are the result of nonhomologous recombinations in specific parts of the genome.

9. HPFH. HPFH is a clinically benign condition characterized by the continued expression of one or both of the $\gamma$-globin genes in adult life; these genes are normally expressed at significant levels only in the foetal period (98). Molecular analysis of several HPFH genes have classified this condition into two forms, the deletional and nondeletional types. Various deletional forms in which the and genes are missing have been described (Fig. 1.15). In the nondeletional form, all globin genes in the -globin gene cluster are intact.

9.1 Deletional HPFH. It is difficult to distinctively separate the deletions causing $\delta$-thal from the HPFH deletions at the molecular level; however, in contrast to the situation in $\delta \beta$-thal, the increased amount of Hb F $(20-30 \%)$ in HPFH heterozygotes is relatively uniformly distributed among the red cells. The lack of $\hat{\beta}$ chains is almost fully compensated for by the increased $\gamma$ chain production, and therefore, heterozygotes have a normal haematology, while the $\delta \beta$-thal hetereozygote is distinctly microcytic and hypochromic. The HPFH condition is often found in Black populations and occasionally in Asian Indians and Italians (231-234).

The mechanism for the persistent $\gamma$ chain synthesis in adults with these deletional types has not been completely elucidated. Several hypotheses have been proposed by which foetal $\mathrm{Hb}$ is elevated in these deletions. The first hypothesis was postulated by Huisman and Schroeder (235) who suggested a controlling gene in the inter $A_{\gamma}-\delta$ gene that regulates $\gamma-g l o b i n$ gene expression $(236)$. This hypothesis was based upon the finding that rela- 

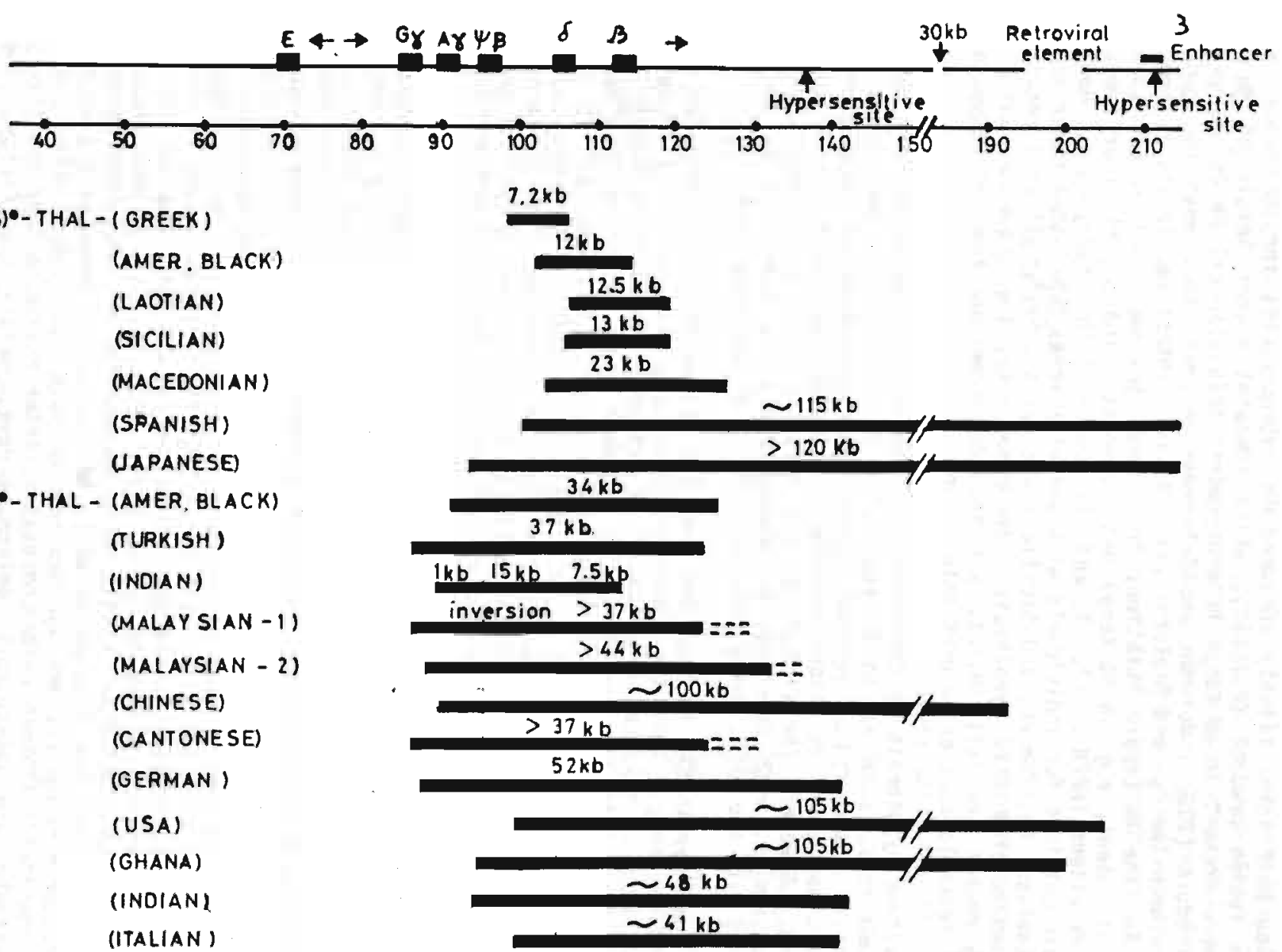

FIG. 15. Deletional types of $6 B$-thalassaemia and HPFH. 
tively low Hb F levels $(1-5 \%)$ appeared in heterozygotes for Hb Lepore, a $\delta-\beta$ gene fusion product $(237,238)$, while somewhat higher levels of $\mathrm{Hb} F$ $(5-8 \%)$ were present in $\mathrm{Hb}$ Kenya heterozygotes; this abnomal $\mathrm{Hb}$ is an $A_{\gamma}-\beta$ fusion product (239). Huisman and Schroeder proposed that when the gene region between the $A_{\gamma}$ - and $\beta-g$ lobin genes is left intact (as in the heterozygotes for the $H b$ Lepore mutation) this leads to lower Hb $F$ levels than when it is absent, e.g. in Hb Kenya heterozygotes. Indeed, all four types of HPFH deletions (HPFH-1, -2, -3 , and -4) supported this hypothesis. However, data obtained for individuals with one of several $(\delta 8)^{\circ}$-thal (American Black, Laotian, Macedonian, and Sicilian) and various $G_{\gamma}(\delta \& \beta)^{\circ}$-thal conditions contradicted this hypothesis. In these cases the sequences within the $A_{\gamma-\beta}$ region are left intact, yet the phenotype for the heterozygote does not resemble that of an HPFH heterozygote.

A second hypothesis by Bernards and Flavell (240) suggested that very large deletions, such as those associated with HPFH, disrupt chromatin structure in a manner that results in continued expression of the $\gamma$-globin genes, whereas short deletions associated with 88 -thal do not have such an effect. However, the finding of the Japanese (241) and Spanish (242) $\delta \beta$-thalassaemias, with deletions of approximately the same size as those associated with the HPFH, makes this unlikely to be the only factor.

A third hypothesis is that DNA from the region of the $3^{\prime}$ endpoint of the deletion brought into the vicinity of the $\gamma$-globin genes may contain sequences such as enhancer elements or an actively transcribing domain of DNA that facilitate the expression of $\gamma$-globin genes to which they have become juxtaposed (241). It is suggested that sequences that act as cis enhancers are brought in from $3^{\prime}$ to the 3 -globin complex. In vitro tests for enhancer activity have demonstrated that DNA sequences $\frac{1}{2} k b^{\prime}$ to the HPFH- 1 are active in enhancing the activity of a bacterial gene in a gene transfer system using mamalian tissue culture cells or K562 human erythroleukemia cells (243).

Recently, a region $3^{\prime}$ to the $\varepsilon$ gene has been reported to play an important role in the regulation of $\beta$-globin gene expression $(102,104,244)$. These so-called hypersensitive sites (HS), that are also termed locus activating regions (LAR) or locus controlling regions (LCR), are erythroid specific and are present at all stages of development. Nt sequence analysis of the HS $5^{\prime}$ to the $E$ gene revealed the presence of two to three enhancer core-like sequences in each of the sites, as well as long stretches of alternating purine and pyrimidine nts that are also found in transcriptional enhancers. A looping out model is proposed for the HPFH conditions in which there is a juxtaposition of the $y$ genes in such a way that they are influenced by the region of the HS sites (4, 3, 2, and 1). In this model, correct temporal regulation results from competition of individual globin gene family members for interaction with LAR sequences. Promoter and proximal enhancer-binding factors synthesized in yolk sac, foetal liver, and bone marrow then influence these competitive interactions, either positively or negatively, and subsequently determine developmental specificity. The differences in foetal $\mathrm{Hb}$ production seen in the HPFH and $\delta \beta$-thal and in the HPFH.

The necessity of stable LAR-promoter interactions could also explain the heterocellular distribution of $\mathrm{Hb} F$ in approximately half the patients 
with nondeletional forms of HPFH. Hb $F$ in these patients is synthesized at high levels only in a fraction (10-20\%) of erythrocytes. The single base pair mutations in the $\gamma$-globin promoter that are apparentiy responsible for the HPFH phenotype may enhance LAR $\gamma$-globin interactions. Since stable LAR $\$$-globin promoter interactions can also occur, individual cells may express either $\gamma$ - or $\beta$-globin mRNA but not both from the mutant chromosomes.

\subsection{NONDELETIONAL HPFH}

The location of sites that are associated with nondeletional mutations leading to HPFH are shown in Table 1.2 .

TABLE 1.2. Substitutions Associated With Nondeletional Types of HPFH

Mutation

Gene $\begin{gathered}\% \text { Hb } F \text { in } \\ \text { Heterozygotes } \\ \text { K }\end{gathered}$

Population/ Ethnic Group

\begin{tabular}{llrll}
\hline$-202(G \rightarrow 6)$ & $G_{\gamma}$ & $10-20$ & 95 & Black \\
$-175(T \rightarrow C)$ & $G_{\gamma}$ & $20-30$ & 89 & Black; Italian \\
$-161(G \rightarrow A)$ & $G_{\gamma}$ & $1-3$ & 70 & Black \\
$-158(G A)$ & $G_{\gamma}$ & $2-5$ & 90 & Multiple origin \\
$-114(G T)$ & $G_{\gamma}$ & $3-5$ & 89 & Black \\
$-202(C \rightarrow T)$ & $A_{\gamma}$ & $2-4$ & 20 & Black \\
$-198(\rightarrow C)$ & $A_{\gamma}$ & $4-12$ & 10 & British \\
$-196(G T)$ & $A_{\gamma}$ & $10-15$ & 10 & Chinese; Italian \\
$-195(G, 6)$ & $A_{\gamma}$ & 7 & 10 & Brazilian \\
$-175(G-C)$ & $A_{\gamma}$ & 30 & 20 & Black \\
$-117(G, A)$ & $A_{\gamma}$ & $10-15$ & 10 & Greek; Black \\
$-114(C \rightarrow T)$ & $A_{\gamma}$ & $3-5$ & -- & Black \\
-114 to -102 (deletion) & $A_{\gamma}$ & 30 & -- & Black \\
\hline
\end{tabular}

Most of these mutations occur in regulatory sequences that are thought to interact with DNA binding proteins $(245-247)$. The Hb $\mathrm{F}$ levels in heterozygotes vary from only a slight increase (1-3\%) to a value of $30 \%$ (245). The $H b F$ is predominantly composed of either $G_{\gamma}$ or $A_{Y}$ chains and can be pancellularly or heterocellulary distributed. The mutations are clustered in and around the distal CCAAT box (positions -111 to -115), the octamer sequence ATGCAAAT (positions -182 to -175 ), and the sequence between -196 and $-2055^{\prime}$ to the cap site of the $\gamma-g$ lobin gene.

An interesting finding in the nondeletional HPFH condition is that the $\$$-globin gene in cis to the mutation is expressed at a lower level than normal; this was demonstrated in families in which a structurally mutant $\beta$-globin gene is in trans to HPFH by showing that the $\beta^{A} \beta^{X}$ ratio is decreased $(245,248-251)$. The activity of the $\delta$ gene is also shown to be consistently decreased in all types of HPFH. Transfection experiments and sequence determination have shown that the $\beta$ - and $\delta$-globin genes from several nondeletional HPFH mutations are normal; this excludes $\beta$ - or $\delta$-thal as a cause of their decreased activity $(252,253)$.

These observations suggest that decreased $\delta$ - and $\beta$-globin gene activities in cis to HPFH-mutations may be due to reciprocal competition for interaction with a common enhancer, and that the HPFH mutations might 
Increase the ability of the $\gamma$ genes to interact with this enhancer, that results in decrease of the $\varepsilon_{-}$and B-globin gene expression in cis. Another possibility is the competition for the same limited transacting factor by the promoters of the $\gamma, \delta$, and $\beta$ genes. Mutations in the $\gamma$ promoters might enhance their affinity for binding with the transacting factors, causing a decreased availability for $\beta$ - and $\delta$-globin promoter sequences.

The most common nondeletional HPFH is the $G T$ substitution at position $-1585^{\prime}$ to the Cap site of $G_{\gamma}$ that causes a slight increase in the ratio of $G_{\gamma}$ to $A_{\gamma}$ chains of $H b F(254)$. This mutation at -158 is detectable by $X m n$ I digestion because of the creation of a new splice site.

\section{DNA POLMMORPHISH}

The use of restriction endonuclease and sequence analysis has made it possible to detect relatively common normal variations in DNA structure (polymorphism), that are inherited in a Mendelian manner and may be used as genetic markers. The first such polymorphism reported was a variation in the recognition site of the restriction endonuclease Hpa I $3^{\prime}$ to the $\beta$-globin gene (255). In most normal human DNA samples, digested with Hpa I, the $\beta$-globin gene was located on a $7.6 \mathrm{~kb}$ DNA fragment. Polymorphism at this site resulted in two fragments $(7.6$ and $13 \mathrm{~kb})$ both containing the $B$ gene. The immediate application of this observation was in antenatal diagnosis (255), but it was also of potential value as a genetic marker in anthropological studies. A restriction site is called polymorphic in a given population if the least frequent allele is present in more than 1\% of individuals (256). The pattern of combination for different polymorphic sites for any chromosome is called a haplotype. In the $\alpha$-globin gene cluster, one in 60 nts is polymorphic; however, few such point mutations are responsible for loss or gain of a restriction site; instead, the polymorphisms seen in the $\alpha$-globin gene cluster are primarily those of variable lengths (189).

Many polymorphic restriction sites are well defined in the $\beta$-globin gene cluster and are used as markers for the determination of the haplotype of the $\beta-g l o b i n$ gene complex (257). Each polymorphic sequence can be elther present $(t)$ or absent $(-)$ for a particular chromosome. If two polymorphic restriction enzyme recognition sequences are randomly associated with each other, the probability of the presence of both these sequences $(t / t)$ is equal to the product of the probabilities of the presence of each individual polymorphic restriction enzyme recognition sequence.

If the two recognition sequences are not randomly associated, the probability of the presence of both recognition sequences will be significantly lower than expected. This non-randomness of association is referred to as "linkage disequilibrium". For a given number of polymorphic sites there is a maximum possible $2^{n}$ combination of recognition sequences. DNA polymorphism, present in and around the human globin genes, have been extensively studied (258). Table 1.3 shows the restriction endonucleases with their respective restriction sites, often used for haplotype studies of the 8-globin gene cluster. The collection of large amounts of data on the haplotypes in Mediterraneans, Blacks, and Southeast Asians, has revealed some interesting findings. For instance, these data show that alleles at these 
varlous polymorphic sites are not randomly associated. The $\gamma$ Hind III and the $\psi \beta$ Hinc II sites located upstream of the $\delta$ gene are grouped in the haplotype combination $[---],[++-+],[+-++],[++--]$, and $[+-+-]$, and are found in Mediterraneans. The other 11 possible combinations are rarely seen or not at all. Statistical tests confirm that the association of alleles at these restriction sites is non-random. The same non-random association of sites is noted for a group of restriction polymorphic sites located $3^{\prime}$ to the $\delta$ gene. However, random association does occur between the two groups. The fact that alleles at polymorphic sites within the groups have been maintained in linkage disequilibrium suggests that recombination in these areas has been relatively infrequent, while the random association between the two groups suggests that crossover in this area is much more frequent. A possible explanation is that the region between the two groups (around the $\delta-\beta$-intergenic area) might be a hot spot for recombination.

TABLE 1.3 Haplotypes in the $\beta$-Globin Gene Cluster

\begin{tabular}{|c|c|c|c|c|c|c|c|c|c|c|c|c|c|c|}
\hline Haplotype & 1 & 2 & 3 & 4 & 5 & 6 & 7 & 8 & 9 & 10 & 11 & 12 & 13 & 14 \\
\hline $1 / b 12$ & + & - & - & - & - & + & - & + & + & + & + & + & + & - \\
\hline II $/ B$ & - & $t$ & + & - & + & - & + & + & + & + & + & + & + & - \\
\hline II I a & - & + & - & + & + & - & + & - & + & + & + & + & - & + \\
\hline$I I I b / C$ & - & + & - & + & + & - & + & + & + & + & + & + & - & + \\
\hline IV & - & + & - & + & + & & & & - & - & + & - & + & \\
\hline $\mathrm{Va}$ & + & - & - & - & - & + & - & + & + & + & + & + & - & + \\
\hline $\mathrm{Vb} / \mathrm{D}$ & + & - & - & - & - & + & - & - & + & + & + & + & - & + \\
\hline VI & - & + & + & - & - & + & - & + & - & - & + & - & + & - \\
\hline $\mathrm{VIIa/Fa/ch2}$ & + & - & - & - & - & + & - & + & - & - & + & - & + & - \\
\hline $\mathrm{Fb}$ & + & - & - & - & - & + & - & - & - & - & + & - & + & - \\
\hline VIII & - & + & - & + & - & + & - & + & + & + & + & + & - & + \\
\hline IX/b II & - & + & - & + & + & - & + & + & + & + & + & + & + & - \\
\hline$x$ & - & + & - & - & - & & & + & - & - & + & - & + & - \\
\hline A/ch 1 & + & - & - & - & - & + & - & + & + & + & + & - & + & - \\
\hline $\operatorname{ch} 3$ & - & + & + & - & + & - & + & + & - & - & + & - & + & - \\
\hline ch4 & & - & - & - & - & + & - & + & + & + & + & + & + & - \\
\hline$E$ & + & - & - & - & - & + & - & + & + & + & + & + & - & + \\
\hline $\mathbf{G}$ & - & + & - & + & + & - & + & + & + & + & + & - & + & - \\
\hline H & - & + & + & - & + & - & + & - & - & - & + & - & + & - \\
\hline I & - & + & - & - & + & - & + & + & - & - & + & - & + & - \\
\hline b) 3 & & - & - & - & + & & & + & + & + & - & - & + & - \\
\hline b) 4 & & - & - & - & + & & & - & - & - & - & - & + & \\
\hline b15 & & + & + & - & + & & & + & + & + & + & - & + & \\
\hline b16 & & - & - & + & + & & & + & + & + & + & + & + & \\
\hline 617 & & + & - & - & + & & & - & + & + & + & & + & \\
\hline
\end{tabular}

a The presence $(t)$ or absence (-) of the 14 common polymorphic restriction sites along each haplotype is presented. The sites are 1 : Hinc II

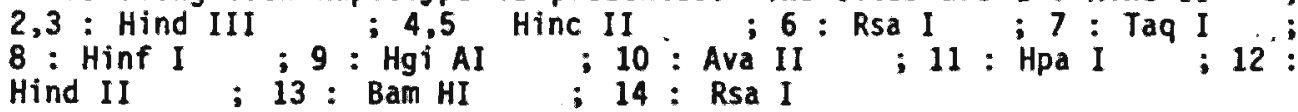

Roman numerals indicate Mediterranean haplotypes; capitals indicate Indian haplotypes; ch indicates Chinese haplotypes; bl indicates Black haplotypes. 
Orkin and Kazazian and their colleagues have found that specific thalassaemia mutations are associated with particular haplotypes (257). However, coupling of a haplotype with a specific mutation is not absolute, even within a single ethnic group. Pirastu et al (259) have found that the $8^{\circ}-39$ mutation in the Sardinian population is associated with nine different haplotypes. These findings may imply that the same mutation has arisen more than once, or more likely, that DNA sequence rearrangements in the $\beta$-globin gene cluster occur with a far higher frequency than was heretofore suspected.

\section{REFERENCES}

1. Herrick, J.B.: Peculiar elongated and sickle-shaped red blood corpuscles in a case of severe anemia. Arch. Intern. Med., 6:517, 1910.

2. Konotey-Ahulu, F.I.D.: The effect of environment on sickle cell disease in West Africa, in Sickle Cell Disease: Diagnosis, Management, Education, and Research, edited by H. Abrumson, J.F. Bertles, and D.L.

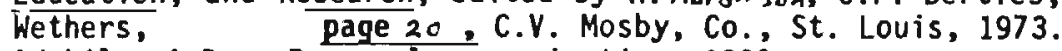

3. Adekile, A.D.: Personal communication, 1990.

4. Adesanya, S.A. and Sofowora, E.A.: Biological standardization of Zanthoxy-Zanthoxyloides roots for anti-sickling activity. Planta. Med. , 48:27, 1983.

5. El-Said, F., Fadulu, S.0., Kuye, J.0., and Sofowora, E.A.: Native cures of Nigeria. II. The antimicrobial properties of the buffered extracts of chewing sticks. Lloydia, 34:172, 1971.

6. Sofowora, E.A. and Isaacs, W.A.: Reversal of sickling and crenation in erythrocytes by the extract of the root Fagara zanthoxyloides. Lloydia, 34:383, 1971.

7. Adekile, A.D., Adeodu, 0.0., Fadulu, S.0., Weinheimer, A., and Sanduja, D.: Preliminary clinical trial of $\mathrm{Nix}-06999$ in the management of sickle cell anaemia. Niger. Med. J., 20:44, 1990.

8. Emmel, V.E.: A study of erythrocytes in a case of severe anemia with elongated and sickle. shaped red blood corpuscles. Arch. Intern. Med., 20:586, 1917 .

9. Pauling, L., Itano, H.A., Singer, S.J., and Hells, I.C.: Sickle-cell anemia, a molecular disease. Science, 110:543, 1949.

10. Itano, H.A. and Neel, J.V.: A new inherited abnomality of human hemoglobin. Proc. Natl. Acad. Sci. USA, 36:613, 1950.

11. Itano, H.A.: A third abnormal hemoglobin associated with hereditary hemolytic anemia. Proc. Nat1. Acad. Sci. USA, 37:775, 1951.

12. Itano, H.A., Bergren, W.R., and Sturgeon, P.: Identification of a fourth abnormal human hemoglobin. J. Am. Chem. Soc., 76:2278, 1954.

13. Zuelzer, H.W., Neel, J.V., and Robinson, A.R.: Abnomal hemoglobins. Progr. Hematol., 1:91, 1956.

14. Körber, E.: Über Differenzen des Blutstoffes, Inaugurale Dissertation, Dorpat., 1866.

15. Bisschoff, H.: Untersuchungen über die Resistenz des Hamoglobins des Menschenblutes besonderer Berucksichtogung des Sauglingsaiters. Zeitschr. Gesamt. Exp. Med., 48:472, 1926.

16. von Krüger, F.: Vergleichende Untersuchungen über die Einfluss einmaliger Blutentziehungen auf die Resistenz des Hamoglobins. Zeitschr. Gesant. Exp. Med., 53:233, 1926.

17. Brinkman, R. and Jonxis, J.H.P.: The occurrence of several kinds of haemoglobin in human blood. J. Physiol., 85:117, 1953. 
18. Ingram, V.M.: A specific chemical difference between the globins of normal human and sickle cell anaemla haemoglobin. Nature, 178: $792,1956$.

19. Konigsberg, W. and Hill, R.J.: The structure of human hemoglobin. III. The sequence of the amino acids of the tryptic peptides of the $\alpha$-chain. J. Biol. Chem., 237:2547, 1962.

20. Braunitzer, G., Gehring-Muller, R., Hilschmann, R., Hilse, K., Hobom, G., Rudloff, V., and Wittmann-Liebold, B.: Die Konstitution des normalen adulten Human-Hamoglobins. Zeitschr. Phys. Chem., 325: 283, 1961 .

21. Schroeder, W.A., Shelton, J.R., Shelton, J.B., Cormick, J., and Jones, R.T.: The amino acid sequence of the $\gamma$-chain of human fetal hemoglobin. Biochemistry, 2:992, 1963.

22. Perutz, M.F. and Lehmann, H.: Molecular pathology of human haemoglobin. Nature, 219:902, 1968.

23. Cooley, T.B. and Lee, P.: A series of cases of splenomegaly in children with anemia and peculiar bone changes. Trans. Am. Pediatr. Soc. , $37: 29,1925$.

24. Caminopetros, J.: Recherches sur 1'anemie erythroblastique infantile des peuples de la Medeterranee orientale, etude anthropologique, etiologique et pathogenique; la transmission hereditaire de la maladie. Ann. Med., 43:104, 1938.

25. Wintrobe, M.M., Mathews, E., Pollack, R., and Dobyns, B.B.: Familial hemopoietic disorder in Italian adolescents and adults resembling Mediterranean disease (thalassaemia). J. Am. Med. Assoc., 114:1530, 1940.

26. Huisman, T.H.J., Prins, H.K., and Van der Schaaf, P.C.: Is alkaliresistant haemoglobin in Cooley's anaemia different from foetal haemoglobin? Experientia, 12:107, 1956.

27. Kunkel, G.H., Ceppellini, R., Muller-Eberhard, U., and Holf, J.: Observations on the minor basic hemoglobin components in the blood of normal individuals and patients with thalassemia. J. Clin. Invest. , 36:1615, 1957.

28. Pauling, L.: Abnormality of haemoglobin molecules in hereditary haemolytic anaemia. The Harvey Lectures Series, 49:216, 1954.

29. Itano, H.A.: The human hemoglobins; their properties and genetic control. Adv. Prot. Chem., 12:215, 1957.

30. Ingram, Y.M. and Stretton, A.O.H.: Genetic basis of the thalassaemia diseases. Nature, 184:1903, 1959.

31. Weatherall, D.J.: The Thalassaemia Syndromes, Blackwell Scientific Publications, Oxford, 1965.

32. Dintzis, H.M.: Assembly of the peptide chains of hemoglobin. Proc. Natl. Acad. Sci. USA, $47: 247,1961$.

33. Heywood, J.D., Karen, M., and Weissman, S.: Amino acids: Incorporation into alpha- and beta-chain of hemoglobin by normal and thalassemic reticulocytes. Science, 146:530, 1964.

34. Temin, H.M. and Mizutani, S.: RNA-dependent DNA polymerase in virions of Rous sarcoma virus. Nature, 226:1211, 1970.

35. Baltimore, D.: RNA-dependent polymerase in virions of RNA tumour viruses. Nature, 226:1209, 1970 .

36. Kacian, D.L., Gambino, R., Dow, L.H., Grossbard, E., Natta, C., Ramirez, F., Spiegelman, S., Marks, P.A., and Bank, A.: Decreased globin messenger RNA in thalassaemia detected by molecular hybridization. Proc. Nat1. Acad. Sci. USA, 70:1886, 1973. 
37. Housman, D., Forget, B.G., Skoultchi, A., and Benz, E.J.: Quantitative deficiency of chain specific messenger ribonucleic acids in the thalassaemia syndromes. Proc. Nat1. Acad. Sci. USA, 70:1809, 1973.

38. Mears, J.G., Ramirez, F, Liebowitz, D., Nakaura, F., Bloom, A., Konotey-Ahulu, F.I.D., and Bank, A.: Changes in restricted human cellular DNA fragments containing globin gene sequences in thalassaemias and related disorders. Proc. Nat1. Acad. Sci. USA, 75:1222, 1978.

39. Flavell, R.A., Bernards, R., Kooter, J.H., de Boer, E., Little, P.F.R., Annison, G., and Williamson, R.: The structure of the human B-globin gene in B-thalassaemia. Nucleic Acids Res.., 6:2749, 1979.

40. Maniatis, T., Hardison, R.C., Lacy, E., Lauer, J., O'Connell, C., Quon, D., Sim, G.K., and Efstratiadis, A.: The isolation of structural genes from libraries of eukaryotic DNA. Cell, 15:687, 1978.

41. Forget, B.G., Cavallesco, C., deRiel, J.K., Spritz, R.A., Choudhary, P.V., Wilson, J.T., Reddy, V.B., and Weissman, S.M.: Structure of the human globin genes, in Eukaryotic Gene Regulation, edited by $T$. Maniatis, R. Axel, and C.F. Fox, page 167 , Academceress las." ICN/UCLA Symposium, 1979.

42. Chehab, F.F., Doherty, M., Cai, S., Kan, Y.W., Cooper, S., and Rubin, E.M.: Detection of sickle cell anaemia and thalassaemias. Nature, $329: 293,1987$.

43. Wong, C., Dowling, C.E., Saiki, R.K., Higuchi, R.G., Erlich, H.A., and Kazazian, H.H., Jr.: Characterization of $\beta$-thalassaemia mutations using direct genomic sequencing of amplified single copy DNA. Nature, $330: 384,1987$.

44. Saiki, R.K., Bugawan, T.L., Horn, G.T., Mullis, K.B., and Erlich, H.A.: Analysis of enzymatically amplified $\beta-g l o b i n$ and HLA-DQ $\alpha$ DNA with allele-specific oligonucleotide probes. Nature:324:163, 1986.

45. Anson, M.L. and Mirsky, A.E.: Protein coagulation and its reversal. The preparation of insoluble globin. Physiol. Rev., 13:469, 1930.

46. Weatherall, D.J.: The thalassaemias, in Haematology, edited by W.J. Williams, E. Beutler, A.J. Erslev, and M.A. Lichtman, 3rd edition, page 493, McGraw-Hill Publishing Company, New York, 1983.

47. Anson, M.L. and Mirsky, A.E.: Hemoglobin, the heme pigments, and cellular respiration. Physiol. Rev., 10:506, 1930.

48. Weatherall, D.J.: The New Genetics and Clinical Practice, 2nd edition, University Press, Oxford, 1985.

49. Collins, S.F. and Weissman, S.M.: The molecular genetics of human haenoglobin. Prog. Nucleic Acids Res. Molec. Biol., 31:315, 1984.

50. Ranney, H.M. and Sharma, V.S.: Structure and function of haemoglobin, in Haematology, edited by W.J. Williams, E. Beutler, A.J. Erslev, and M.A. Lichtman, 3rd edition, page 353, McGraw-Hill Publishing Company, New York, 1983.

51. Weathera11, D.J., Hood, W.G., Jones, R.W., and Clegg, J.B.: The developmental genetics of human hemoglobin, in Progress in Clinical and Biological Research, Experimental Approaches for the Study of Hemoglobin Switching, edited by G. Stamatoyannopoulos and A.W. Nienhuis, Vol. 191, page 3, Alan R. Liss, Inc., New York, 1985.

52. Nute, P.E., Pataryas, H.A., and Stamatoyannopoulos, 6.: The GY and Ay hemoglobin chains during human fetal development. Am. 3. Hum. Genet., 35:271, 1973. 
53. Wilson, J.B. and Hulsman, T.H.J.: Detection and quantitation of normal and abnormal hemoglobins in adults and newborns, in The Hemoglobinopathies, edited by T.H.J. Huisman, Methods in Hematology, Vol. 15, page 32, Churchill Livingstone, Edinburgh, 1986.

54. Huisman, T.H.J.: Human hemoglobin abnomalities. Am. Assoc. Clin. Chem., 1:1, 1984.

55. Gilman, J.G., Harano, T., Nakatsuji, T., Bakioglu, I., Reese, A.L,. Gardiner, M.B., and Huisman, T.H.J.: The ratio of the $G_{\gamma}$ and $A_{\gamma}$ chains: Variations due to anomalies at the molecular level. Ann. N.Y. Acad. Sci., 445:235, 1985.

56. Schaffner, H.: chapter' Thtraduat.c..', in Acting Elements in Initiation, edited by $Y$. Gluzman, page 1 , Cold Spring Harbor Laboratory, New York, 1985.

57. Lacy, E. and Maniatis, T.: The nucleotide sequence of a rabbit $\beta$-globin pseudo-gene. Cell, 21:545, 1980.

58. Charnay, P., Mellon, P., and Maniatis, T.: Linker scanning mutagenesis of the $5^{\prime}$ flanking region of the mouse 8 -major globin gene: Sequence requirements for transcription in erythroid and nonerythroid cells. Mol. Cell. Biol., 5:1498, 1985.

59. Dierks, P., van Ooyen, A., Cochran, M.D., Dobkin, C., Reiser, J., and Weissmann, C.: Three regions upstream from the Cap site are required for efficient and accurate transcription of the rabbit $\beta-910-$ bingene in mouse 3 T6 cells. Ce11, 32:695, 1983.

60. Benoist, C., O'Hare, K., Breathnach, R., and Chambon, P.: The ovalbumin gene-sequence of putative control regions. Nucleic Acids Res., $8: 128,1980$.

61. Shenk, T.: Methods of DNA and RNA Sequencing, edited by S.M. Meissman, page 349, Praeger, New York, 1983.

62. Khoury, G. and Gruss, P.: Enhancer elements. Ce11, 33:313, 1983.

63. Gruss, P.: Review: Magic enhancers? DNA, 3:1, 1984.

64. Gillies, S.D., Morrison, S.L., Oi, V.T., and Tonegawa, S.: A tissuespecific transcription enhancer element is located in the major intron of a rearranged imunoglobulin heavy chain gene. Cell, 33:717, 1983.

65. Gillies, S.D., Folson, V., and Tonegawa, S.: Cell type-specific enhancer element associated with a mouse MHC gene, $E$. Nature, 310: $594,1984$.

66. Walker, M.D., Edlund, T., Boulet, A.M., and Rutter, W.J.: Cell-specific expression controlled by the 5'-flanking region of insulin and chymotrysin genes. Nature, 306:577, 1983.

67. Goodbourn, S., Zinn, K., and Maniatis, T.: Human $\beta$-interferon gene expression is regulated by an inducible enhancer element. Cell, 41:509, 1985.

68. Prochownik, E.V.: Relationship between an enhancer element in the human antithrombin III gene and an immunoglobulin light-chain gene enhancer. Nature, 316:845, 1985.

69. Rogers, B.L., Sobnosky, M.G., and Saunders, G.F.: Transcriptional enhancer within the human placental lactogen and growth hormone multigene cluster. Nucleic Acids Res., 14:7647, 1985.

70. Scholer, H.R. and Gruss, P.: Specific interaction between enhancercontaining molecules and cellular components. Cell, 36:403, 1984.

71. Sassone-Corsi, P., Wildeman, A., and Chambon, P.: A trans-acting factor is responsible for the sv40 entancer activity in vitro. Nature, 313:458, 1985. 
72. Queen, C. and Stafford, J.: Fine mapping of an immunoglobulin gene activator. Mol. Cell. Biol., 4:1042, 1984.

73. Ephrussi, A., Church, G.M., Tonegawa, S., and Gilbert, W.: B lineage-specific interactions of an immunoglobulin enhancer with cellular factors in vivo. Science, $227: 134,1985$.

74. Banerji, J., Rusconi, S., and Schaffner, W.: Expression of a betaglobin gene is enhanced by remote SV40 DNA sequences. Cell, 27:298, 1981.

75. Chao, M.V., Mellon, P., Charnay, P., Maniatis, T., and Axel, R.: The regulated expression of $\beta$-globin genes introduced into mouse erythroleukemia cells. Cell, 32:483, 1983.

76. Humphries, R.K., Ley, T., Turner, P., Moulton, A.D., and Nienhuis, A.H.: Differences in human $\alpha-, \beta-$, and $\delta-g l o b i n$ gene expression in monkey kidney cells. Cell, 30:173, 1982.

77. Mellon, P., Parker, V., Gluzman, Y., and Maniatis, T.: Identification of DNA sequences required for transcription of the human $\alpha-g$ lobin gene in a new SV40 host-vector system. Cell, 27:279, 1981.

78. Treisman, R., Green, M.R., and Maniatis, T.: Cis- and trans-activation of globin gene transcription of transient assays. Proc. Natl. Acad. Sci. USA, 80:7428, 1983.

79. Green, M.R., Treisman, R., and Maniatis, T.: Transcriptional activation of cloned human beta-globin genes by viral immediate-early gene production. Cell, 35:137, 1983.

80. Kingston, R.E., Baldwin, A.S., and Sharp, P.A.: Transcription control by oncogenes. Cell, 41:3, 1985.

81. Webber, F. and Schaffner, H.: Simian virus enhancer increases RNA polymerase density within the linked gene. Nature, 315:75, 1985.

82. Treisman, R. and Maniatis, T.: Simian virus 40 enhancer inreases number of RNA polymerase II molecule on linked DNA. Nature, 315:72, 1985.

83. Serfiing, E., Jasin, M., and Schaffner, H.: Enhancers and eukaryotic gene transcription (review). Trends Genet., 1:224, 1985.

84. Dynan, W.S. and Tjian, R.: Control of eukaryotic messenger RNA synthesis by sequence-specific DNA-binding proteins. Nature, 316: 774, 1985.

85. Galas, D.J. and Schmitz, A.: DNase footprinting; a simple method for the detection of protein-DNA binding specificity. Nucleic Acids Res., 5:3157, 1978.

86. Fried, M. and Crothers, D.M.: Equilibria and kinetics of lac represson-perator interactions by polyacrylamide gel electrophoresis. Nucleic Acids Res., 9:6505, 1982.

87. Briggs, M.R., Kadonaga, J.T., Bell, S.P., and Tjian, R.: Purification and biochemical characterization of the promoter-specific transcription factor, Spl. Science, 234:47, 1986.

88. Maniatis, T., Goodbourn, S., and Fischer, J.A.: Regulation of inducible and tissue-specific gene expression. Science, 236:1237, 1987.

89. Ptashne, M.: Gene regulation by proteins acting nearby and at a distance (review). Nature, 322:697, 1986.

90. Takahashi, K., Vigneron, M., Mathes, H., Wildeman, A., Zenke, M., and Chambon, P.: Requirement of stereospecific alignments for initiation from SV40 early promoter. Nature, 319:121, 1986.

91. Cereghini, S., Sargosti, S., Yaniv, M., and Hamer, D.W.: SV $40-\alpha-g$ lobulin hybrid rinichromosome differences in DNase i hypersensitivity of promoter and. enhancer sequences. Eur. J. Blochem., 144:545, 1984. 
92. Yang, L., Rowe, T.C., Nelson, E.M., and LIU, L.F.: In vitro mapping of topoisomerase II-specific cleavage sites on SV40 chromatin. Cell, $41: 127,1985$.

93. Mirkovitch, J., Mirault, M-E., and Laenmli, U.K.: Organization of the higher-order chromatin loop; specific DNA attachment sites on nuclear scaffold. Cell, 39:223, 1984.

94. Jackson, D.A. and Cook, P.R.: Transcription occurs at a nucleoskeleton. EMBO J., 4:919, 1985.

95. van der Ploeg, L.H.T. and Flavell, R.A.: DNA methylation in the human xS-locus in erythroid and non-erythroid tissues. Cell, 19:947, 1960.

96. Mavilio, F., Giampaolo, A., Care, A., Migliaccio, G., Calandrini, M., and Peschle, C.: Molecular mechanisms of human hemoglobin switching: Selective undermethylation and expression of globin genes in embryonic, fetal, and adult erythroblasts. Proc. Natl. Acad. Sci. USA, $80: 6907,1983$.

97. Busslinger, M., Hurst, J., and Flavell, R.A.: DNA methylation and the regulation of globin gene expression. Cell, 34:197, 1983.

98. Groudine, M., Kohwi-Shigematsu, T., Gelinas, R., Stamatoyannopoulos, G., and Papayannopoulous, Th.: Human fetal to adult hemoglobin switching: Changes in chromatic structure of the $\beta$-globin locus. Proc. Nat1. Acad. Sci. USA, 80:7551, 1983.

99. Tuan, D., Solomon, W., Li, Q., and London, I.M.: The "P-1ike globin" gene domain in human erythroid cells. Proc. Natl. Acad. Sci. USA, $82: 6384,1985$.

100. Forrester, H.C., Thompson, C., Elden, J.T., and Groudine, M.: A developmentally unstable chromatin structure in the human $B-g l o b i n$ gene cluster. Proc. Nat1. Acad. Sci. USA, 83:1359, 1986.

101. Grosveld, F., van Assendelft, G.B., Greaves, D.R., and Kollias, G.: Position-independent, high level expression of the human $\mathbf{P}-\mathrm{globin}$ gene in transgenic mice. Cell, 51:975, 1987.

102. Forrester, W.C., Takegawa, S., Papayannopoulous, Th., Stamatoyannopoulos, G., and Groudine, M.: Evidence for locus activation region: The formation of developmentally stable hypersensitive sites in globin-expressing hybrids. Nucleic Acids.Res., 15:10159, 1987.

103. van der Ploeg, L.H.T., Koenings, A., Oordt, M., Roos, D., Bernini, L., and Flavell, R.: $\gamma \beta$-Thalassaemia studies showing that deletion of the and genes influences $\beta$-globin gene expression in man. Nature, 283:637, 1982.

104. Curtin, P., Pirastu, M., Kan, Y.H., Gobert-Jones, J.A., Stephens, A.D. , and Lehmann, H.: A distant gene deletion affects $\beta$-globin gene function in an atypical $\gamma \delta \hat{\beta}$-thalassemia. J. clin. Invest., 75:1554, 1985.

105. Driscoll, M.C., Dobkin, C., and Alter, B.P.: A distant deletion associated with non-expression of a $\beta^{S}$ gene: Detection by PFGE. Blood, 70:74a (Suppl. 1), 1987.

106. Koussis, D., Vanin, E., Delange, T., Flavell, R., and Grosveld, F.6.: - Globin gene inactivation by DNA translocation in $\gamma \beta$-thalassaemia. Nature, 306:662, 1983.

107. Curtin, P.T. and Kan, Y.W.: The inactive $\beta$-globin gene on a $\gamma 8 \beta$-thalassemia chromosome has a normal structure and functions normally in vitro. Blood, 71:766, 1988.

108. Coggins, L.W., Grindlay, G.J., Vass, J.K., Slater, A.A., Montague, P., Stinson, M.A., and Paul, J.: Repetitive DNA sequences near three human $\beta$-type globin genes. Nucleic Acids Res., 8:3319, 1980. 
109. Coggins, L.W., Lanyon, W.G., Slater, A.A., Grindlay, G.J., and Paul, J.: Characterization of Alu family repetitive sequences which flank human $\mathbf{p}$-type globin genes. Biosct. Rep., 1:309, 1981.

110. Coggins, L.W., Vass, J.K., Stinson, M.A., Lanyon, W.G., and Paul, J.: A $B 1$ repetitive sequence near the mouse $\&$-major globin gene. Gene, $17: 113,1982$.

111. Jagadeeswaran, P., Forget, B.G., and Weissman, S.M.: Short interspersed repetitive DNA elements in eukaryotes: Transposable DNA elements generated by reverse transcription of RNA pol III transcript? Ce11, 26:141, 1981.

112. Henthorn, P.S., Smithies, 0., and Mager, D.L.: Molecular analysis of deletions in the human $\beta$-globin gene cluster: Deletion junctions and locations of breakpoints. Genomics, 6:226, 1990.

113. Jagadeeswaran, P., Biro, P.A., Tuan, D., Pan, J., Forget, B.G., and Meissman, S.M.:

in Human Genetics, Part A: The Unfolding Genome, , page 29, Alan R. Liss, Inc., New York, 1982.

114. International Hemoglobin Information Center, Hemoglobin, 15:139, 1991.

115. Shaeffer, J.R., Kingston, R.E., McDonald, M.J., and Bunn, H.F.: Competition of normal $\beta$ chains and sickle haemoglobin $\beta$ chains for $\alpha$ chains as a posttranslational control mechanism. Nature, 306:498, 1983.

116. Bunn, H.F. and McDonald, M.J.: Electrostatic interactions in the assembly of human haemoglobin. Nature, 306:498, 1983.

116a. Shaeffer, J.R., McDonald, M.J., and Bunn, H.F.: Assembly of normal and abnormal human hemoglobins. Trends Biochem. Sci., 6:158, 1981.

117. Huisman, T.H.J.: Trimodality in the percentages of chain variants in heterozygotes: The effect of the number of active $\mathrm{Hb}$ structural loci. Hemoglobin, 1:349, 1977.

118. Fairbanks, V.F., Gilchrist, G.S., Brimhall, B., Jereb, J.A., and Goldston, E.C.: Hemoglobin E trait reexamined: A cause of microcytosis and erythrocytosis. Blood, 53:109, 1979.

119. Dean, J. and Schecter, A.N.: Sickle-cell anemia: Molecular and cellular bases of therapeutic approaches. (Three parts) N. Engl. J. Med., 299:752; 299:804; 299:863, 1979.

120. Williams, W.J., Beutler, E., Erslev, A.J., and Lichtman, M.A.: Haematology, 3rd edition, McGraw-Hill Publishing Company, New York, 1986.

121. Serjeant, G.R.: The Clinical Features of Sickle Cell Disease. Clinical Studies 4, North-Holland Publishing Company, Amsterdam, 1974.

122. Murayama, M. and Nalbandian, R.M.: Sickle Cell Haemoglobin, Little, Brown and Company, Boston, 1973.

123. Milner, P.F., Miller, C., Grey, R., Seakins, M., deJong, W.W., and Went, L.N.: Kemoglobin $O$ Arab in four Negro families and its interactions with Hemoglobin S and Hemoglobin C. N. Engl. J. Med., 283: 1417, 1970.

124. McCurdy, P.R.: Clinical and physiological studies in a Negro with sickle cell Hemoglobin D disease. N. Engl. J. Med., 262:961, 1960.

125. Goldbers, M.A., Husson, M.A., and Bunn, H.F.: The participation of Hemoglobins $A$ and $F$ in the polymerization of sickle hemoglobin. J. Biol. Chem., 252:3414, 1977.

126. Bookchin, R.M., Nagel, R.L., and Balazs, T.: Role of hybrid tetramer formation in gelation of Haemoglobin S. Nature, 256:667, 1975.

127. Bakloglu, I., Hattori, Y.. Kutlar, A., Mathew, C., and Huisman, T.H.J.: Five adults with mild sickle cell anemia share a $\$ S$ chromosome with the same haplotype. Am. J. Hematol., 20:297, 1985. 
128. Goldberg, M.A., Brugnara, C.. Dover, G.J.. Schapira, L., Charache, S., and Bunn, H.F.: Treatment of sickle cell anemia with hydroxyurea and erythropoietin. N. Engl. J. Med., 323:366, 1990.

129. Charache, S., Dover, G.J., Smith, K.D., and Talbot, C.C.: Treatment of sickle cell anemia with 5-azacytidine results in increases in fetal hemoglobin production and is associated with non-random hypomethylation of DNA around the $\gamma-\delta-\beta$ globin gene cluster. Proc. Natl. Acad. Sci. USA, 80:4842, 1983.

130. Sears, D.A.: The morbidity of sickle cell trait. A review of the literature. Am. J. Med., 64:1021, 1978.

131. Barbotin, M. and Ducloux, M.: La drepanocytose heterozygote chez T'adulte à la patraquerie drepanocytaire. Med. Trop., 36:237, 1976.

132. Pagnier, J., Mears, J.G., Dunda-Belkhodja, O., Schaefer-Rego, K.E., Beldjord, C., Nagel, R.L., and Labie, D.: Evidence for the multicentric origin of the sickle cell hemoglobin gene in Africa. Proc. Natl. Acad. USA, 81:1771, 1984.

133. Antonarakis, S.E., Boehm, C.D., Serjeant, G.R., Theisen, C.E., Dover, G.J., and Kazazian, H.H., Jr.: Origin of the $3 S_{-g l o b i n}$ gene in Blacks: The contribution of recurrent mutation or gene conversion or both. Proc. Nat1. Acad. Sci. USA, 81:853, 1984.

134. Landman, H.: Haemoglobinopathies and Pregnancy. Thesis, Groningen, The Netherlands, 1988.

135. Geerdink, R.A., Okura, K., Li Fo Sjoe, E., Schillhorn van Veen, J.M., and Bartstra, H.A.: Serum factors and red cell enzymes in Carib and Arowak Indians from Surinam. Trop. Geogr. Med., 27:260, 1975.

136. Luyken, R. and Luyken-Koning, F.W.M.: Studies on the physiology of nutrition in Surinam. VII. Serum iron. Trop. Geogr. Med., 13:42, 1961.

137. Ranney, H.M., Larson, D.L., and McCormack, G.H.: Some clinical, biochemical and genetic observations on Hemoglobin $\mathrm{C} . \mathrm{J}, \mathrm{Clin}$. Invest., $32: 1277,1953$.

138. Smith, E.W. and Krevans, J.R.: Clinical manifestations of Haemoglobin C disorders. Bull. Johns Hopkins Hosp., 104:17, 1959.

139. Mrabet, N.T., McDonald, M.J., Turci, S.M., and Bunn, H.F.: Electrostatic interactions in the sub-unit assembly of human hemoglobin. Fed. Proc., 43:1577, 1984.

140. Singer, K.: Pure (homozygous) Hemoglobin C disease. Blood, 9:1023, 1954.

141. Charache, S., Conley, C.L., Waugh, D.F., Ugoretz, R.J., and Spurre11, R.J.: Pathogenesis of hemolytic anemia in homozygous Hemoglobin $C$ disease. J. Clin. Invest., 46:1795, 1967.

142. Bodmer, W.F. and Cavalli-Sforza, L.L.: Genetics, Evolution and Man, W.H. Freeman, San Francisco, 1967.

143. Jonxis, J.H.P.: The frequency of Haemoglobin $S$ and $C$ carriers in Curacao and Surinam, in Abnormal Haemoglobins, page Blackwell Scientific Publishers, Oxford, 1959.

144. Gijzel, W.P., Adhin, S.D., and Oemrawzingh, I.: Abnomal haemoglobins in Surinam. I. Frequency among the different ethnic groups. Sur. Med. Bul1., 2:1, 1978.

145. Pik, C., Loos, J.A., Jonxis, J.H.P., and Prins, H.K.: Hereditary and acquired blood factors in the negroid population of Surinam. Trop. Geogr. Med., 17:61, 1965.

146. Heatheral1, D.J.: The Thalassaemias, Churchill Livingstone, London, 1983. 
147. Gatti, F., Vandepitte, J., Lehmann, H., and Gaffney, P.J.: Hemoglobin $E$ in a Congolese family. Ann. Soc. Belg. Med. Trop., 48:527, 1968.

148. Bunn, H.F., Meriwether, H.D., Balcerzak, S.P., and Rucknagel, D.L.: Oxygen equilibrium of Hemoglobin E. J. Clin. Invest., 51:2984, 1972 .

149. Kazazian, H.H., Jr., Waber, P.G., Boehm, C.D., Lee, J.J., Antonarakis, S.E., and Fairbanks, V.F.: Hemoglobin $E$ in Europeans - Further evidence for multiple origins of the $\beta-E-g l o b i n$ gene. (Technical note.) Am. J. Hum. Genet., $36: 212,1984$.

150. Huisman, T.H.J., Punt, K., and Schaad, J.D.G.: Thalassemia minor associated with Hemoglobin-B 2 heterozygosity. A family report. Blood, $17: 747,1961$.

151. Codrington, J.F., Li, H-W., Kutlar, F., Gu, L-H., Ramachandran, M., and Huisman, T.H.J.: Observations on the levels of $\mathrm{Hb}_{2} \mathrm{~A}_{2}$ in patients with different $\beta$-thalassemia mutations and a $\delta$ chain variant. Blood, $76: 1246,1990$.

152. Sanger, F., Nicklen, S., and Coulson, A.R.: DNA sequencing with chain terminating inhibitors. Proc. Natl. Acad. Sci. USA, 74:5463, 1977.

153. Li, H-W., Codrington, J.F., Schiliro, G., Wadsworth, L.D., Beris, Ph., Adekile, A.D., and Huisman, T.H.J.: The usefulness of sequence analysis of amplified DNA for the identification of 8 chain variants. Hemoglobin, 15:77, 1991.

154. Nute, P.E.: Multiple hemoglobin $\alpha$ chain loci in monkeys, apes and man. Ann. N.Y. Acad. Sci.. 241:39, 1974.

155. Liebhaber, S.A., Cash, F.E., and Ballas, S.K.: The dominant role of the $\alpha_{2}$ locus in mRNA and protein synthesis. J. Biol. Chem., 261: $15327,1986$.

156. Cash, F.E., Monplaisir, N., Goossens, M., and Liebhaber, S.A.: Locus assignment of two $\alpha$-globin structural mutants from the Caribbean basin: $\alpha$ Fort de France $(\alpha 45 A$ rg) and $\alpha$ Spanish Town ( $\alpha 27 \mathrm{Val})$. $74: 833,1989$.

157. Liebhaber, S.A., Cash, F.E., and Main, D.M.: Compensatory increase in $\alpha$ globin gene expression in indiduals heterozygous for the $\alpha$-thalassemia-2 deletion. J. Clin. Invest., 76:1057, 1985.

158. Felice, A.E., Mayson, S.M., Webber, B.B., Milier, A., Gravely, M.E., and Huisman, T.H.J.: Hb S, Hb G-Philadelphia and $\alpha$-thalassemia- 2 in a Black family. Pediatr. Res., 14:266, 1980.

159. Surrey, S., Ohene-Frampong, K., Rappaport, E., Atwater, J., and Schwartz, E.: Linkage of $\alpha$-Philadelphia to $\alpha$-thal assemia in AfricanAmericans. Proc. Natl. Acad. Sci. USA, $77: 4885,1980$.

160. Felice, A.E., Ozdonmez, R., Headlee, M.E., and Huisman, T.H.J.: Organization of $\alpha$-chain genes among $H b$ G-Philadelphia heterozygotes in association with $\mathrm{Hb} S, \beta$-thalassemia and $\alpha$-thalassemia-2. Biochem. Genet., 20:689, 1982 .

161. Bruzdzinski, C.J., Sisco, K.L., Ferrucci, S.J., and Rucknagel, D.L.: The occurrence of the $\alpha^{G}$-Philadelphia globin allele on a double-locus chromosome. Am. J. Hum. Genet., 36:101, 1984.

162. Liebhaber, S.A. and Cash, F.E.: Locus assignment of $\alpha$-globin structural mutations by hybrid selected transiation. $\mathrm{J}$. clin. Invest., $75: 64,1985$.

163. Beris, P., Huber, P., Miescher, P.A., Milson, J.B., Kutlar, A., Chen, S.S. and Huisman, T.H.J.: Hb Q-Thailand-Hb $H$ disease in a Chinese living in Geneva, Switzerland: Characterization of the variant and identification of the two $\alpha$-thalassemic chromosomes. Am. J. Hematol.. $24: 395,1987$. 
164. Lee-Potter, J.P., Deacon-Smith, R.A., Simpkiss, M.J., Kamuzora, H., and Lehmann, H.: A new cause of haemolytic anaemia in the newborn. A description of an unstable foetal haemoglobin: $F$ Poole, $\alpha_{2} G_{2} 130$ TryptophaniGlycine. J. Clin. Pathol., 28:317, 1975.

165. Hayashi, A., Fujita, T., Fujimura, M., and Titani, K.: A new abnomal

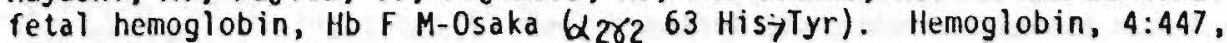
1980.

166. Huisman, T.H.J., Kutlar, F., Nakatsuji, T., Bruce-Tagoe, A., Kilinc, Y., Cauchi, M.N., and Romero Garcia, C.: The frequency of the $\gamma$ chain variant $A_{\gamma} t$ in different populations, and its use in evaluating $\gamma$ gene expression in association with thalassemia. Hum. Genet., 71:127, 1985.

167. Huisman, T.H.J.: The occurrence of $\gamma$ chain variants and related anomalies in various populations of the world, in Distribution and Evolution of Hemoglobin and Globin Loci, edited by J.E. Bowman, Vol. 4, page 119, Elsevier Science Publishing Co. Inc., Amsterdam, 1983.

168. Huisman, T.H.J. and Jonxis, J.H.P.: The Hemoglobinopathies Techniques of Identification, Clinical and Biochemical Analysis, Vol. 6, Marcel Dekker, Inc., New York, 1977.

169. Fei, Y.J., Kutlar, F., Harris, H.F., II, Wilson, M.M., Milana, A., Sciacca, P., Schiliro, G., Masala, B., Manca, L., Altay, C., Gurgey A., de Pablos, J.Ma., Villegas, A., and Huisman, T.H.J.: A search for anomalies in the $z, \alpha, \beta$, and $\gamma$ globin gene arrangements in normal Black, Italian, Turkish, and Spanish newborns. Hemoglobin, 13:45, 1989.

170. Higgs, D.R. and Weatherall, D.J.: The $\alpha$-thalassemias. Curr. Topics Hemator., 4:37, 1983 .

171. Lie-Injo, L.E., Solai, A., Herrera, A.R., Nicolaisen, L., Kan, Y.W., Wan, W.P., and Hasan, K.: Hb Bart's level in cord blood and deletions of $\alpha$-globin genes. Blood, 59:370, 1982.

172. Lauer, J., Shen, C-K., and Maniatis, T.: The chromosomal arrangement of human $\alpha-l i k e$ globin genes: Sequence homology and $\alpha-g l o b i n g e n e$ deletions. Cell, 20:119, 1980.

173. Higgs, D.R., Hill, A.V.S., Bowden, D.K., Weatherall, D.J., and Clegg, J.B.: Independent recombination events between the duplicated human $\alpha$ globin genes; implications for their concerted evolution. Nucleic Acids Res., 12:6965, 1984.

174. Nakatsuji, T., Landman, H., and Huisman, T.H.J.: An elongated segment of DNA observed between two human $\alpha$ globin genes. Hum. Genet., 74 : $368,1986$.

175. Goossens, M., Dozy, A.M., Embury, S.H., Zachariades, Z., Hadjiminas, M.G., Stamatoy annopoulos, G., and Kan, Y.W.: Triplicated $\alpha$-globin loci in humans. Proc. Natl. Acad. Sci. USA, 77:518, 1980

176. Trent, R.J., Higgs, D.R., Clegg, J.B., and Weatheral1, D.J.: A new triplicated $\alpha$-globin gene arrangement in man. Br. J. Haematol.. 49: $149,1981$.

177. Fortina, P., Delgrosso, K., Rappaport, E., Poncz, M., Ballas, S.K., Schwartz, E., and Surrey, S.: A large deletion encompassing the entire $\alpha-1$ ike globin gene cluster in a family of Northern European extraction. Nucleic Acids Res., 16:11223, 1988.

178. Gonzalez-Redondo, J.M., Diaz-Chico, J.C., Malcorra-Azpiazu, J.J., Balda-Aguirre, and Huisman, T.H.J.: Characterization of a newly discovered $\alpha$-thalassaemia-1 in two Spanish patients with $H b H$ disease. Br. J. Haematol., 70:459, 1988. 
179. Nicholls, R.D.. Fischel-Ghodsian, N., and Hlggs, D.R.: Recombination at the human $\alpha$-globin gene cluster: Sequence features and topological constraints. Cell, 49:369, 1987.

180. Bowden, D.K., Hill, A.V.S., Higgs, D.R., Oppenheimer, S.J., Weatherall, D.J., and Clegg, J.B.: Different haematologic phenotypes are associated with the leftrard $\left(-\alpha^{4.2}\right)$ and rightward $\left(-\alpha^{3.7}\right) \alpha^{+}$-thalassaemia deletions. J. Clin. Invest., 79:39, 1987.

181. Maude, G.H., Higgs, D.R., Beckford, H., Grandison, Y., Mason, K., Taylor, B., Serjeant, B.E., and Serjeant, G.R.: $\alpha$. Thalasem.il in 4 t/1e

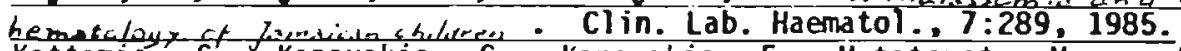

182. Kattamis, C. Kanavakis, C., Kanavakis, E., Metatoxotou-Mavromati, A., Tzotzos, S., and Synodinos, J.: Correlation of clinical phenotype to genotype in Haemoglobin $H$ disease. Lancet, 1:442, 1988.

183. Moi, P., Cash, F.E., Liebhaber, S.A., Cao, A., and Pirastu, M.: An initiation codon mutation (AUGGUG) of the human $\alpha_{1}-g$ lobin gene. Structural characterization and evidence for a mild thalassemic phenotype. J. Clin. Invest., 80:1416, 1987.

184. Pirasu, M., Saglio, G., Chang, J.C., Cao, A., and Kan, Y.W.: Initiation codon mutation as a cause of $\alpha$ thalassemia. J. Biol. Chem., $259: 12315,1984$.

185. Trent, R.J., Wilkinson, T., Yakas, J., Carter, J., Lammi, A., and Kronenberg, H.: Molecular defects in two examples of severe $H b H$ disease. Scand. J. Haematol., $36: 272,1986$.

186. Kutlar, F., Reese, A.L., Hsia, Y.E., Kleman, K.M., and Huisman, T.H.J.: The types of hemoglobin and globin chains in hydrops fetalis. Hemoglobin, 13:671, 1989.

187. Liang, S.T., Wong, V.C.W., So, W.H.K., Ma, H.K., Chan, V., and Todd, D.: Homozygous $\alpha$-thalassaemia: Clinical presentation, diagnosis and management. A review of 46 cases. Br. J. Obst. Gynaecol., 92:680, 1985.

188. Weatherall, D.J., Clegg, J.B., and Boon, W.K.: The haemoglobin constitution of infants with Haemoglobin Bart's hydrops foetalis syndrome. Br. J. Haematol., 18:357, 1970.

189. Liebhaber, S.A.: $\propto$ Thalassemia. Hemoglobin, 13:685, 1989.

190. Antonarakis, S.E., Kazazian, H.H., Jr., and Orkin, S.H.: DNA polymorphism and molecular pathology of human globin gene clusters. Hum. Genet., 69:1, 1984.

191. Kutlar, A.: The ß-Thalassemia Repository, 13:775, 1989.

192. Huisman, T.H.J.: Frequencies of common $\not$-thalassaemia alleles among different populations; variability in clinical severity. Br. J. Haematol., 76:454, 1990.

193. Thomas, E.D., Buckner, C.D., Sanders, J.E., Papayannopoulos, T., Borgna-Pignatti, C., De Stefano, P., Sullivan, K.M., Clift, R.A.. and Storb, R.: Marrow transplantation for thalassaemia. Lancet, 2:227, 1982.

194. Lucarelli, G., Galimberti, M., Polchi, P., Giardini, C., Politi, P., Baronciani, D., Angeluce, E., Manenti Delfini, C., Aurelli, G., and Moretto, P.: Bone marrow transplantation in patients with advanced thalassaemia. N. Engl. J. Med., 316:1085, 1987.

195. Krivit, W. and Whitley, C.B.: Bone marrow transplantation for genetic diseases. N. Engl. J. Med., 316:1085, 1987. 
196. Thomas, E.D., Sanders, J.E., Buckner, C.D., Papayannopoulos, T., Borgna-Pignatti, C., De Stefano, P., Sullivan, K.M., Deeg, H.J.e Witherspoon, R.P., Applebaum, F.R., Cllft, R.A., and Storb, R.: Marrow transplantation for thalassacmia. Ann. N.Y. Acad. Sci.. 445:417, 1985.

197. Van den Berg, H., Bernini, L.F., Sukhai, R.N., and Vossen, J.M.J.J.: Allogene beenmergtransplantatie bij $\beta$-thalassemie. Ned. Tijdschr. Geneeskd., 131:18, 1987.

198. Chao, M.V., Mellon, P., Charney, P., Maniatis, T., and Axel, R.: The regulated expression of $\beta$-globin genes introduced into mouse erythroleukemia cells. Cell, 32:483, 1983.

199. Breathnach, R. and Chambon, $P$, : Organization and expression of eucaryotic split genes coding fór proteins. Ann. Rev. Biochem., 50: 349,1981 .

200. Rogers, J. and Wall, R.: A mechanism for RNA splicing. Proc. Natl. Acad. Sci. USA, 77:1877, 1980.

201. Mount, S.M., Pettersson, I., Hinterberger, M., Kurmas, A., and Steitz, J.A.: The U.I. Small nuclear RNA-protein complex selectively binds a $5^{\prime}$ splice site in vitro. Cell, 33:509, 1983.

202. Wieringa, B., Meyer, F., Reiser, J., and Weissman, C.: Unusual splice sites revealed by mutagenic inactivation of an authentic splice site of the rabbit $\beta$-globin gene. Nature, 301:38, 1983.

203. Felber, B.K.. Orkin, S.H., and Hamer, D.H.: Abnormal RMA splicing causes one form of thalassemia. Cell, 29:895, 1983.

204. Treisman, R., Orkin, S.H., and Maniatis, T.: Specific transcription and RNA splicing defects in five cloned $\beta$-thalassaemia genes. Nature, $302: 591,1983$.

205. Spence, S.E., Pergolizzi, R.G., Donovan-Peluso, M., Kosche, K.A., Dobkin, C.S., and Bank, A.: Five nucleotide changes in the large intervening sequence of a $\beta$ globin gene in a $\beta^{+}$thalassemia patient. Nucleic Acids Res., 10:1283, 1982.

206. Dobkin, C., Pergolizzi, R.G., Bahre, P., and Bank, A.: Abnormal splice site in a mutant human $\beta$-globin gene not at the site of a mutation. Proc. Nat1. Acad. Sci. USA, 80:1184, 1983.

207. Cheng, T., Orkin, S.H., Antonarakis, S.E., Potter, M.J., Sexton, J.P., Markham, A.F., Giardina, P.J.Y., Li, A., and Kazazian, H.H., Jr.: $\beta$-Thalassemia in Chinese: Use of in vivo RNA analys is and oligonucleotide hybridization in systematic characterization of molecular defects. Blood 61:64a (Suppl. 1), 1983.

208. Orkin, S.H., Kazazian, H.H., Jr., Antonarakis, S.E., Oster, H., Goff, S.C., and Sexton, J.P.: Abnormal R.N.A. processing due to the exon mutation of $\beta^{E}$-globin gene. Nature, 300:768, 1982.

209. Felber, B.K., Orkin, S.H., and Hamer, D.H.: Abnormal RMA splicing causes one form of thalassemia. Cell, 29:895, 1982.

210. Goldsmith, M.E., Humphries, R.K., Ley, T., Cline, A., Kantor, J., and Nienhuis, A.W.: Silent nucleotide substitution in a $\beta^{+}$-thalassemia globin gene activates splice site in coding sequence RNA. Proc. Natl. Acad. Sci. USA, 80:2318, 1983.

211. Yang, K.G., Kutlar, F., George, E., Wilson, J.B., Kutlar, A., Stoming, T.A., Gonzalez-Redondo, J.M., and Huisman, T.H.J.: Molecular charafterization of $\beta$-globin gene mutations in Malay patients with $H \mathrm{~b} E-\overline{-}-$ thalassaemia and thalassaemia major. $\mathrm{Br}$. J. Haematol., 72:73, 1989.

212. Kazazian, H.H.. Jr. and Boeha, C.D.: Molecular basis and prenatal diagnosis of 3 -thalassevia. Blood, 72:1107, 1988. 
213. Gonzalez-Redondo, J.M., Stoming, T.A., Lanclos, K.D., Gu, Y.C., Kutlar, A., Kutlar, F., Nakatsuji, T., Deng, B., Han, I.S., McKie, V.C.. and Huisman, T.H.J.: Clinical and genetfc heterogeneity in Black patients with homozygous 8 -thalassemia from the Southeastern United States. Blood, 72:1007, 1988.

214. Fucharoen, S., Fucharoen, G., Fucharoen, P., and Fukumaki, Y.: A novel ochre mutation in the $\beta$-thalassemia gene of a Thai. J. Biol. Chem., 264:7780, 1989.

215. Spritz, R.A., Jagadeeswaran, P., Choudary, P.V., Biro, P.A., Elder, J.T., deRiel, J.K., Manley, J.L., Gefter, M.L., Forget, B.G., and Weissman, S.M.: Base substitution in an intervening sequence of a $\mathbf{P}^{+}$-thalassemic human globin gene. Proc. Nat1. Acad. Sci. USA, 78: 2455, 1981 .

216. Fukumaki, Y., Ghosh, P.K., Benz, E.J., Jr., Reddy, V.B., Lebowitz, P., Forget, B.G., and Weissman, S.M.: Abnormally spliced messenger R.N.A. in erythroid cells form patients with $B^{+}$thalassemia and monkey cells expressing a cloned $\beta^{+}$thalassemia genes. Cell 28:585, 1982.

217. Pergolizzi, R., Spritz, R.A., Spence, S., Goossens, M., Kan, Y.W., and Bank, A.: Two cloned $\$$ thalassemia genes are associated with amber mutations in codon 39. Nucleic Acids Res., 9:7065, 1981.

218. Stolle, C.A., Payne, M.S., and Berun, E.J.: Equal stabilities of normal $\beta$ globin and nontranslatable $\beta^{\circ}-39$ thalassemic transcripts in cell free extracts. Blood, 70:293, 1987.

219. Gonzalez-Redondo, J.M., Stoming, T.A., Kutlar, A., Kutlar, F., Lanclos, K.D., Howard, E.F., Fei, Y.J., Aksoy, M., Altay, C., Gurgey, A., Basak, A.N., Efremov, G.D., Petkov, G., and Huisman, T.H.J.: A C.r substitution at $n t-101$ in a conserved DNA sequence of the promoter region of the $\$$-globin gene is associated with "silent" $\mathrm{P}$-thalassemia.
Blood, 73:1705, 1989.

220. Oner, R., Agarwal, S., Dimovski, A.J., Efremov, G.D., Petkov, G.H., Altay, C., Gurgey, A., and Huisman, T.H.J.: The GA mutation at position $+223^{\prime}$ to the Cap site of the $\beta$-globin gene as a possible cause of $\beta$-thalassemia. Hemoglobin, 15:67, 1991.

221. Orkin, S.H., Cheng, T-C., Antonarakis, S.E., and Kazazian, H.H., Jr.: Thalassemia due to a mutation in the cleavage polyadenylation signal of the human $\mathrm{p}$-globin gene. EMBO J., 4:453, 1985.

222. Kazazian, H.H., Jr., Orkin, S.H., Antonarakis, S.E., Sexton, J.P., Boehm, C.D., Goff, S.C., and Waber, P.G.: Molecular characterization of seven $\beta$-thalassemia mutations in Asian Indians. EMBO J., 3:593, 1984.

223. Gonzalez-Redondo, J.M., Kattamis, C., and Huisman, T.H.J.: Characterization of three types of $3^{\circ}$-thalassemia resulting from a partial deletion of the $\$$-globin gene. Hemoglobin, 13:337, 1989.

224. Aulehla-Scholtz, C., Spielberg, R., and Horst, J.: A $\beta$-thalassemia

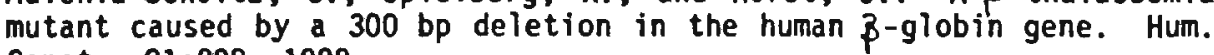
Genet., 81:298, 1989.

225. Popovitch, B.W., Rosenblatt, D.S., Kendall, A.G., and Nishioka, Y.: Molecular characterization of an atypical B-thalassemia caused by a large deletion in the 5 ' $\mathrm{P}$-globin gene region. Am. J. Hum. Genet., $39: 797,1986$.

226. Schnee, J., Griese, E.V., Eigel, A., and Horst, J.: ß-Thaiassemia gene analysis in a Turkish family revelas a 7 bp deletion in the coding region. Blood, 73:2224, 1989. 
227. Orkin, S.H., Sexton, J.P., Goff, S.C., and Kazazfan, H.H., Jr.: Inacativation of an acceptor RNA splice site by a short deletion in $\beta$ thalassemid. J. Biol. Chem., 258:7249, 1983.

228. Kazazian, H.H., Jr. and Bochm, C.D.: Molecular basis and prenatal diagnosis of 8 -thalassemia. Blood, $72: 110 \overline{7}, 19 \overline{88}$.

229. Sukumaran, P.K., Huisman, T.H.J., Schroeder, W.A., McCurdy, P.R., Freehafer, J.T., Bouver, N., Shelton, J.R., Shelton, J.B., and Apell, G.: A homozygote for the $\mathrm{Hb}_{\mathrm{G}}$ type of foetal haemoglobin in India: A study of two Indian and four Negro families. Br. J. Haematol., 23:403, 1972.

230. Nakatsuji, T., Gilman, J.G., Sukumaran, P.K., and Huisman, T.H.J.:

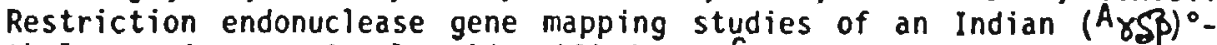
thalassaemia previously identified as Gy-HPFH. Br. J. Haematol., $57: 663,1984$.

231. Jagadeeswaran, P., Tuan, D., Forget, B.G., and Weissman, S.M.: A gene deletion ending at the midpoint of a repetitive DNA sequence in one form of hereditary persistence of foetal haemoglobin. Nature, 296:469, 1982 .

232. Tuan, D., Feingold, E., Newman, M., Weissman, S.M., and Forget, B.G.: Different $3^{\prime}$ endpoints of deletions causing $\delta \beta$-thalassemia and hereditary persistence of fetal hemoglobin: Implications for the control of $\gamma$-globin gene expression in man. Proc. Natl. Acad. Sci. USA, 80: $6937,1983$.

233. Henthorn, P.S., Mager, D.L., Huisman, T.H.J., and Smithies, 0.: A gene deletion ending with a complex array of repeated sequences $3^{\prime}$ to the human $\beta-g l o b i n$ gene cluster. Proc. Natl. Acad. Sci. USA, 83: $5194,1986$.

234. Camaschella, C., Serra, A., Gottardi, E., Revello, D., Mazza, U., and Saglio, G.: New hereditary persistence of fetal hemoglobin deletion has the breakpoint within the $3^{\prime} \beta$-globin gene enhancer. Blood, $75: 1000,1990$.

235. Huisman, T.H.J., Schroeder, W.A., Efremov, G.D., Duma, H., Mladenovski, B., Hyman, C.B., Rachmilewitz, E.A., Bouver, N., Miller, A., Brodie, A., Shelton, J.R., Shelton, J.B.,. and Apell, G.: The present status of the heterogeneity of fetal hemoglobin in 8 -thalassemia: An attempt to unify some observations in thalassemia and related cond1tions. Ann. N.Y. Acad. Sci., 232:107, 1974.

236. Schroeder, W.A. and Huisman, T.H.J.: Hemoglobin F in $\beta$ thalassemia and related conditions. Ann. N.Y. Acad. Sci., 344:240, 1980.

237. Baglioni, C.: The fusion of two peptide chains in Hemoglobin Lepore and its interpretation as a genetic deletion. Proc. Natl. Acad. Sct. USA, $48: 1880,1962$.

238. Flavell, R.A., Kooter, J.M., deBoer, E., Little, P.F.R., and Williamson, R.: Analysis of the $\beta$-S-globin gene loci in normal and $\mathrm{Hb}$ Lepore DNA: Direct determinatioh of gene linkage and intergene distance. Cell, 15:25, 1978.

239. Huisman, T.H.J., Wrightstone, R.N., Wilson, J.B., Schroeder, W.A., and Kendall, A.G.: Hemoglobin Kenya, the product of fusion of $\gamma$ and 3 polypeptide chains. Arch. Biochem. Biophys., 153:850, 1972.

240. Bernards, R. and Flavel1, R.A.: Physical mapping of the globin gene deletion in hereditary persistence of foetal haemoglobin (HPFH). Nucleic Acids Res., 8:1521, 1980.

241. Shiokava, S., Yamada, H., Takihara, Y., Matsunaga, H., Ohba, Y., Yamamoto, K., and Fukumaki, Y.: Molecular analysis of Japanese $\delta \beta$ thalassemia. Blood, 72:1771, 1988. 
242. Camaschella, C., Serra, A., Saglto, G., Baiget, M., Malgarett1, N., Mantovani, R., and 0ttolenghi, S.: The $3^{\prime}$ ends of the deletions of Spanish 88 -thalassemia and Black HPFH 1 and 2 lle within 17 kilobases. Blood, 70:593, 1987.

243. Elise, A., Feingold, E., and Forget, B.G.: The breakpoint of a large deletion causing hereditary persistence of fetal hemoglobin occurs within an erythroid D.N.A. domain remote from the $\beta$-globin gene cluster. Blood, $74: 2178,1989$.

244. Towmes, T.M. and Behringer, R.R.: Humga globin locus activation region (LAR): Role in temporal control. T.I $C, E$ : Le sige

245. Ottolenghi, S., Mantovani, R., Micolis, S., Ronchi, A., and Giglioni, B.: DNA sequences regulating human globin gene transcription in nondeletional hereditary persistence of fetal hemoglobin. Hemoglobin, 13:523, 1989.

246. Sykes, K. and Kaufman, R.: Abstract, Sixth Conference on Hemoglobin Switching, Airlie, Virginia, 1988.

247. Martin, D.I.K., Tsai, S.F., and Orkin, S.H.: Increased $\gamma$-globin expression in a nondeletion HPFH mediated by an erythroid-specific DNA-binding factor. Nature, 338:435, 1989.

248. Collins, F.S., Stoeckert, C., Serjeant, G., Forget, B., and Weissman, S.: Gyp' hereditary persistence of fetal hemoglobin: Cosmid cloning and identification of a specific mutation $5^{\prime}$ to the $G_{\gamma}$ gene. Proc. Natl. Acad. Sci. USA, 81:489, 1984.

249. Surrey, S., Delgrosso, K., Malladi, P., and Schwartz, E.: A single

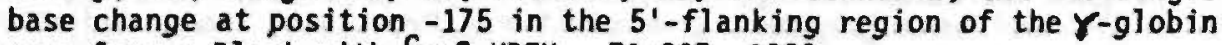

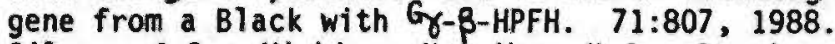

250. Gilman, J.G., Mishima, N.. Wen, X.J.. Stoming, T.A., Lobel, J., and Huisman, T.H.J.: Distal CCAAT box deletion in the Ar globin gene of two Blacks with elevated fetal Ar globin. Nucleic Acids Res., $16: 10635,1988$.

251. Stoming, T.A., Stoming, G.S., Lanclos, K.D., Fei, Y.J., Atlay, 6., Kutlar, F., and Huisman, T.H.J.: An Ár type of nondeletional hereditary persistence of fetal hemoglobin with a $\mathrm{F} X$ mutation at position -175 to the Cap site of the Ar globin gene. Blood, 73:329, 1989.

252. Camaschella, C., Oggiano, L., Sampietro, M., Gottardi, E., Alfarano, A., Pistidda, P., Dore, F., Taramelli, R., and Ottolenghi, S.: The homozygous state of $G$ to A -117 Ar HPFH. Biood, 73:1999, 1989.

253. Giglioni, B., Casini, C., Mantovani, R., Merli, S., Comi, P., OttoTenghi, S., Saglio, G., Camaschella, C., and Mazza, U.: A molecular study of a family with Greek hereditary persistence of fetal hemoglobin and 3-thalassemia. EMBO J., 3:2641, 1984.

254. Gilman, J.G. and Huisman, T.H.J.: DNA sequence variation associated with elevated Gr globin production. Blood, 66:783, 1985.

255. Kan, Y.W. and Dozy, A.M.: Polymorphism of D.N.A. sequence adjacent to the human $3-$ globin structural gene: Relationship to sickle mutation. Proc. Nat1. Acad. Sci. USA, 76:631, 1978.

256. Nienhuis, A.K., Anagnou, N.P., and Ley, T.J.: Advances in thalassemia research. Blood, 63:738, 1984.

257. Orkin, S.H., Kazazian, H.H., Jr., Antonrakis, S.E., Goff, S.C., Boehm, C.D., Sexton, J.P., Waber, P.G., and Giardina, P.J.Y.: Linkage in $\beta$-thalassaemia mutations and $\hat{\beta}$-globin gene polymorphisms with ONA

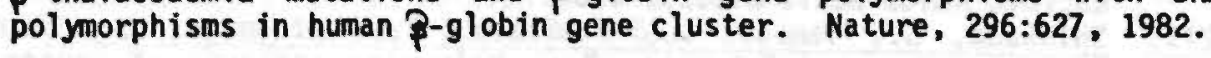


258. Antonarakts, S.E., Boehm, C.D., Giardina, P.J.Y., and Kazazian, H.H., Jr.: Nonrandom association of polymorphic restriction sites in the B-globin gene cluster. Proc. Natl. Acad. Sc1. USA, 79:137, 1982.

259. Pirastu, M., Galanello, R., Doherty, M., Tuveri, T., Cao, A., and Kan, Y.W.: The same $\$-g l o b i n$ gene mutation is present on nine different 3 -thalassemia chromosomes in a Sardinian population. Proc. Nat1. Acad. Sci. USA, 84:2882, 1987. 
CHAPTER 2

MATERIALS AND METHODS 


\section{MATERIALS AND METHODS}

This chapter provides details of some procedures that are not described in detail in Chapters 3 through 6 . Application of the procedures to the studies involving the $\mathrm{Hb}$ variants and thalassaemia mutations can be found in these chapters together with the appropriate illustrations.

\section{PATIENTS}

2.1 Newborns. During a six months period 201 cord blood samples were collected at the Paramaribo Hospitals (Academisch Ziekenhuis, Diaconessenhuis, 's Lands Hospitaal and St.Vincentius Ziekenhuis). The samples were stored at $+4^{\circ} \mathrm{C}$ and shipped by special air service co Augusta, GA, USA, within two weeks of collection. Each shipment consisted of approximately 40 samples and was received within three to four days after mailing. Informed consent was obtained prior to collection.

2.2 Native Indians. Blood was collected from 131 inhabitants of three native Indian villages located at the west side of Surinam (Donderskamp, Corneliskondre, and Kalebaskreek). The samples were received in Augusta within four days of collection. Informed consent was obtained prior to collection.

2.3 Patients on Record in the Local Hospitals and From Local Physicians. In order to study the different types of thalassaemias and possible abnormal $\mathrm{Hb}$ variants in the Surinam population, thalassaemic patients who attended the hospital clinics, and their relatives, were invited to participate in this study. From the patient records kept in the laboratory of the Academisch Ziekenhuis in Paramaribo, a selection was made of patients with high $\mathrm{Hb} \mathrm{A}_{2}$ values and with abnormal band.patterns on cellulose acetate electrophoresis. Most of these patients and their relatives were invited to participate in this study. Samples from some members of one family (see Chapter 4) were collected in The Netherlands by Dr. K. Punt and his associates. Informed consent was obtained prior to collection.

\section{BLOOD COLLECTIOH: SHIPMENT}

Blood samples were collected in vacutainers (Becton Dickinson Vacutainer Systems, coagulant. The samples were kept cold $\left(+4^{\circ} \mathrm{C}\right)$ until the time of shipment to Augusta, GA, USA. They were shipped in wet ice, and many samples were received within four days after shipment.

\section{HB ANALYSIS}

In this methodology section, the procedures will be listed in the sequence they were used after we received the blood samples. 
4.1 Hacmatological Data. These were obtained with a fully automated Sysmex CC-720 cell counter (TOA Medical Electronics Co. Ltd., Kobe, Japan). The measurement of the mean corpuscular volume (MCV) is normally a useful parameter for the assessment of the possible presence of thalassacmia and certain $H b$ variants ( $H D E$ and $H D C$ ), particularly when the $M C V$ values are less than $80 \mathrm{fl}$. However, it must be noted that in many of our $\beta$-thal patients, the expected microcytosis was not often definite because the analyses of most of the samples took place two to three weeks after collection, and the storage conditions in Surinam were not always optimal. Several of the blood samples were partly haemolyzed upon arrival. The mean corpuscular $\mathrm{Hb}$ (МСH) values are probably more reliable ( $\mathrm{MCH}<25 \mathrm{pg}$ ) for an evaluation of a possible thalassaemia as it is less variable with age or with improper storage of blood samples. It must also be emphasized that an abnormal result is non-specific and can be caused by a number of acquired conditions such as iron deficiency, and a variety of other uncommon haematological abnormalities.

4.2 IEF. Red cell lysates were analyzed by IEF which will separate variants that co-migrate in conventional procedures such as cellulose acetate and citrate agar electrophoresis. Basset et al (1) identified $70 \mathrm{Hb}$ variants by IEF; 31 of these could not be separated from Hb $S$ by cellulose acetate electrophoresis. IEF will separate $H b$ variants with pI's that differ by 0.02 or greater. Traditionally, IEF has been performed using polyacrylamide as the supporting matrix. The gels used in this study were made of agarose and were purchased from Isolab, Inc., Akron, OH, USA. Agarose offers a high gel strength with sufficient porosity to allow proteins with molecular weights of up to $10^{6}$ daltons to migrate freely. The buffers used in this procedure were also obtained from the same supplier. Band identification is performed by comparing distances to known controls (see Fig. 3.1 of Chapter 3). Bands with a similar isoelectric point ( $H b E, H b O, H b C$ ) were characterized with citrate agar electrophoresis. The IEF procedure was used primarily for the initial screening of the samples to detect an abnormal pattern.

4.3 Citrate Agar Electrophoresis. This method is capable of resolving some variants that do not separate from $\mathrm{Hb} A, \mathrm{Hb} S$, or $\mathrm{Hb} C$ by cellulose acetate electrophoresis or IEF. Electrophoresis on agar gel with a citrate buffer at $\mathrm{pH} 6.1$ causes most Hbs to move cathodically from the point of origin and with relative mobilities that are different from those obtained with electrophoretic techniques at alkaline pH. This method is useful in detecting haemoglobinopathies in cord blood samples because of the distinct mobility of $H b F$. A major disadvantage of this procedure is that the identification of many of the common $H b$ variants such as $H b E$ or Hb G-Philadelphia cannot be made because they co-migrate with Hb $A$.

4.4 Fetal Hb Quantitation. Quantitation of $H b F$ is important in the diagnosis of the various forms of thalassaemias, sickle cell disease, the Hb E syndromes, and the HPFH syndromes, particularly in individuals aged 6 months or older. Two methods are in use in our laboratory for the quantitation of $H b F$; the alkali resistance method and a recently developed HPLC method. The alkali resistance of of $\mathrm{Hb} F\left(\& F_{A D}\right)$ provides a rapid and reasonably simple technique; there are several published variations of the alkali denaturation test (2-5). The method used in this study is a modified procedure as described by Betke et al (2). The Hb is first converted to 
cyanmethb before denaturation which prevents false-positive values, particularly in patients with increased concentrations of the alkaline-resistant carbonmonoxyHb ( $\mathrm{CO}-\mathrm{Hb})$, e.g. in heavy smokers.

A recently developed HPLC procedure using a weak poly(aspartic acid) cation exchange column was also used to quantitate $H b F$ and other $H b$ fractions; the method will be discussed later in this chapter. Quantitative data obtained with this method have been compared with those by the alkali denaturation procedure $\left(\% F_{A D}\right)$ and Fig. 2.1 provides this information. The HPLC method was shown to have an overall higher accuracy rate in estimating $H b F$ levels, especially for values <10\%.
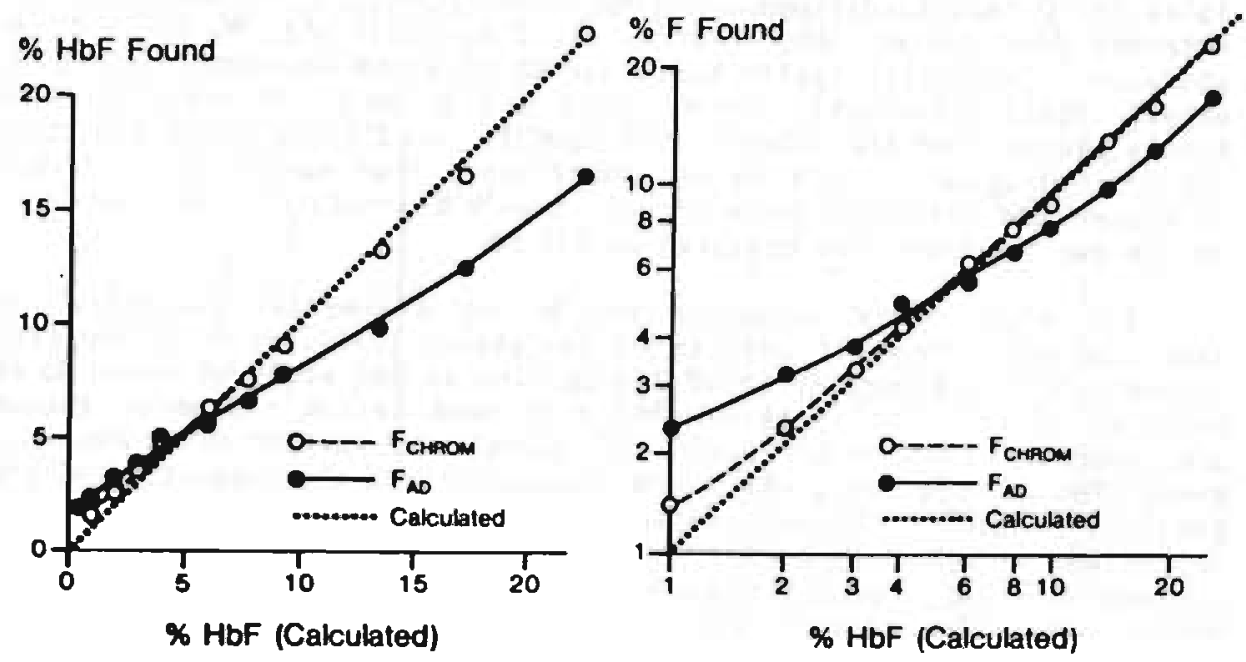

FI6. 2.1 A comparison of Hb $F$ values determined by PolyCAT chromatography ( $F$ Chrom) and by alkali denaturation $\left(F_{A D}\right)$, presented on a linear scale (left) and logarithmic scale (right). Artificial mixtures of $\mathrm{Hb} F$ and $\mathrm{Hb} \mathrm{A}$ were analyzed. Reproduced from Kutlar et al, Hum. Genet., 85:106-110, 1990, with permission.

4.5 DEAE-Cellulose Chromatography. In order to study the $\gamma$ chain composition, $\mathrm{Hb} F$ was first isolated by DEAE-cellulose chromatography. Depending upon the amount of $\mathrm{Hb} F$ present in the red cell lysate, one of the isolation following procedures of $\mathrm{Hb} F$ was used: a) $\mathrm{Hb} F \quad\langle 3 \%$. Isolation was on a medium sized $(30 \mathrm{~cm} \times 1.5 \mathrm{~cm})$ column packed with DE-52 cellulose. The anion exchanger was equilibrated by repeated washings with a $0.2 \mathrm{M}$ glycine $+15 \mathrm{mM} \mathrm{KCN}$ buffer, $\mathrm{pH} 7.75$. About $60 \mathrm{mg} \mathrm{Hb}$ was applied to the column and the chromatogram was developed for 15 hours at a flowrate of $50 \mathrm{ml}$ per hour using a $0.2 \mathrm{M}$ glycine, $0.01 \% \mathrm{KCN}, 0.02 \mathrm{M} \mathrm{NaCl}$ developer. 
The Hb F fraction located at the top was cut from the column, poured into an analytical sized column ( $1 \mathrm{~cm} \times 20 \mathrm{~cm}$ ), and eluted with a stripping buffer $(0.2 \mathrm{M} \mathrm{NaCl}, 0.01 \% \mathrm{KCN}, 0.2 \mathrm{M}$ glycine, $\mathrm{pH} 7.7)$. b) Three percent $<H b F$ <20\%. Analytical sized columns $(1 \mathrm{~cm} \times 20 \mathrm{~cm})$ were used. Column preparation and equilibration were as mentioned above. About 20-30 mg of $\mathrm{Hb}$ was applied to the column and chromatographed at room temperature using a $30 \mathrm{ml}$ per hour flowrate for 5 hours. The $\mathrm{Hb} F$ fraction located at the top was cut from the column, poured into a microcolumn $(0.5 \mathrm{~cm} \times 7 \mathrm{~cm})$ and eluted with a stripping buffer $(0.2 \mathrm{M} \mathrm{NaCl}, 0.01 \% \mathrm{KCN}, 0.2 \mathrm{M}$ glycine). c) $\mathrm{Hb} F<20 \%$. It is not necessary to isolate $\mathrm{Hb} F$ from such red cell lysates as these lysates can be applied directly to a reversed phase HPLC column.

4.6 Quantitation of $\mathrm{Hb} \mathrm{A}_{2}$. Elevated levels of $\mathrm{Hb} \mathrm{A}_{2}$ are characteristic for 3 -thal conditions. Column chromatography with commercial columns obtained from Isolab, Inc. (Akron, OH, USA) (Quik-Sep, Hb A2 test system) was used. The Isolab system makes use of an anion exchanger [diethylaminoethyl) (DEAE) cellulose]. Hb $A_{2}$ (plus $H b E$ or $H b C$, if present) is selectively eluted from the column under specific conditions of $\mathrm{pH}$ and chlorideion concentration. There is no interference from $H b S$. The remaining $H b$ is eluted and collected as a single, separate fraction. Absorbance values of the two fractions are measured at $415 \mathrm{~nm}$.

4.7 HPLC. This technique has become a powerful analytical method that has influenced all aspects of analytical chemistry. In the past two decades, HPLC has been successfully applied to the study of human Hb abnormalities (1-6). Ion exchange HPLC with weak cation and anion exchangers are used for the identification of normal and variant $H b s$, and reversed phase HPLC is used for globin chain separation and the separation of tryptic peptides of globin chains. Depending upon the kind of hb quantitation or separation needed, appropriate columns and buffers are used. Analytical columns will facilitate the quantitation of $\mathrm{Hb}$ types in red cell lysates, while preparative columns are used to isolate $\mathrm{Hb}$ fractions for further studies, including structural analysis.

4.8 Cation HPLC. Quantitation of Hbs was performed on a PolyCAT A cation exchange column, $5 \mu \mathrm{m}$ particles, $4.6 \mathrm{~mm} \times 200 \mathrm{~mm}$, obtained from PolyLC, Columbia, MD, USA. The chromatogram was developed with two buffers: Developer A was $35 \mathrm{mM}$ Bis-Tris, $3 \mathrm{mM} \mathrm{NH}_{4}$ acetate, $1.5 \mathrm{mM} \mathrm{KCN,} \mathrm{pH} 6.47$; developer $B$ was $35 \mathrm{mM}$ Bis-Tris, $1.5 \mathrm{mM} \mathrm{KCN,} 150 \mathrm{mM}$ Na acetate, $16.85 \mathrm{mM}$ $\mathrm{NH}_{4}$ acetate, $\mathrm{pH}$ 7.0. A gradient was developed for 85 minutes from $25 \% \mathrm{~B}$ to $85 \% \mathrm{~B}$. The column was purged for 5 minutes with $100 \%$ B and equilibrated for 10 minutes with $25 \% \mathrm{~B}+75 \% \mathrm{~A}$. Some $50-200 \mathrm{mg} \mathrm{Hb}$ in red cell lysates was applied, the absorbance of the effluent was continuously recorded at $415 \mathrm{~nm}$, and peaks were quantified (as area \%) by a Data Module. The flowrate was $0.8 \mathrm{ml} / \mathrm{min}$, and the chart speed $0.25 \mathrm{~cm} / \mathrm{min}$. When using this method to isolate $\mathrm{Hb}$ (up to $200 \mathrm{mg}$ ) that are present in small amounts in red cell lysates, a preparative PolyCAT A column (21 $\mathrm{mm} \times 250 \mathrm{~mm}, 12 \mu \mathrm{m}$ particles; same manufacturer) was used. The developers were the same as for the analytical column except for the composition of developer B that contained $225 \mathrm{mM}$ Na acetate instead of $150 \mathrm{mM}$. The flowrate was adjusted to $5 \mathrm{ml} / \mathrm{min}$. The desired $\mathrm{Hb}$ fraction was collected and concentrated by filtration under pressure (Amicon Diaflow, Amicon, Danvers, MA, USA). The order of elution of the different $\mathrm{Hb}$ types is $\mathrm{Hb}$ Bart's and $\mathrm{Hb} \mathrm{H}$, followed by Hbs I, N, F, different types of $J, A, A_{2} / E, G, D, S, 0$-Arab, C-Harlen, and $C$. 
4.9 Reversed Phase HPLC. The $\gamma$ chain composition of Hb F (1.e. $;$ Gy, Ar, or $A_{x}{ }^{T}$ was determined by reversed phase HPLC as developed by Shelton et al (12) and Kutlar et al (13) using the large-pore Vydac $\mathrm{C}_{4}$ column and two water-acetonitrile-trifluoroacetic acid (TFA) developers. Developer A was $60 \%$ acetonitrile, $0.1 \%$ TFA, $40 \%$ water; developer 8 was $20 \%$ acetonitrile, $0.1 \%$ TFA, $80 \%$ water. A gradient was developed for 70 minutes from $50 \%$ A to $60 \% \mathrm{~A}$. The column was purged with $100 \% \mathrm{~A}$ and equilibrated for 10 minutes with $50 \% \mathrm{~A}+50 \% \mathrm{~B}$. Some $50-800 \mu \mathrm{Hb}$ in red cell lysate was applied to the column; the absorbance of the effluent was continuously recorded at $220 \mathrm{~nm}$. Fig. 2.2 provides an example of a chromatogram. The order of elution of the different $H b$ chains is: $\beta E, \beta C, \beta S, \beta A, \delta, \alpha, A_{\gamma}, G_{\gamma}$, and AyI. This method can also be used to isolate Hb chains for structural analyses. For this purpose, a larger column is used and a flowrate of $5 \mathrm{ml} / \mathrm{min}$ is applied. The buffers are the same as for analytical use.

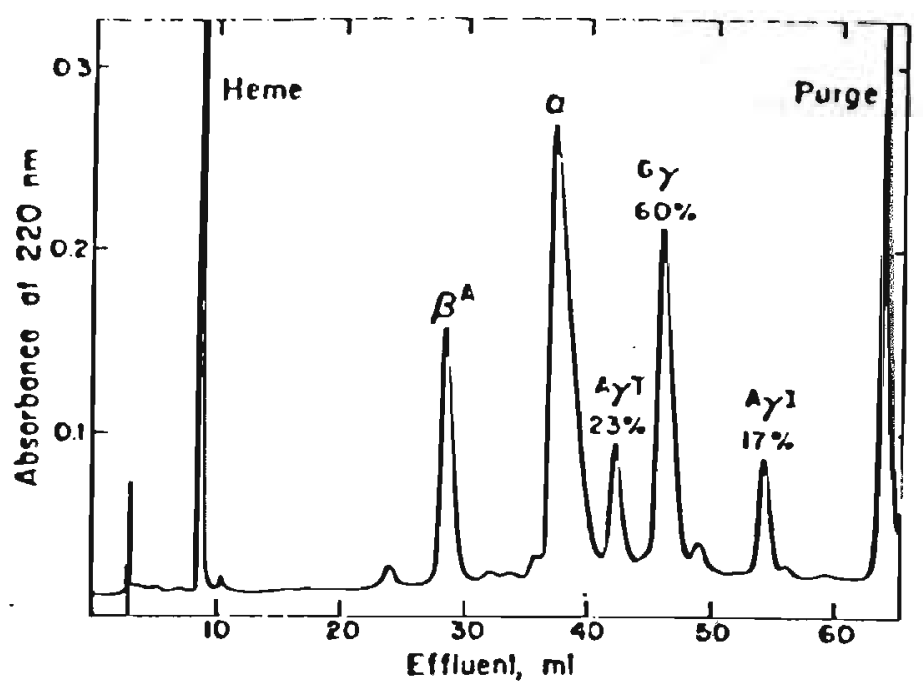

FIG. 2.2 Separation of the globin chains in the cord blood of a newborn child. Sample was $0.10 \mathrm{mg}$.

\section{STRUCTURAL ANALYSES}

In our survey a $\mathrm{Hb}$ variant with an abnormal $\alpha$ chain was discovered in a Creole family (see Chapter 3). The methodology used in characterizing this $\alpha$ chain variant is described in detail below. The first steps were the identification and quantitation of the $\mathrm{Hb}$ variant by IEF and HPLC, respectively. After these steps, the abnormal Hb was isolated by DEAE-cellulose chromatography (as described for $H b F$ isolation). The polypeptide chains of the $\mathrm{Hb}$ variant were separated by carboxymethylcellulose (CMC) chromatography (14). The isolated $\alpha$ chain was digested with trypsin, and the resulting tryptic peptides were separated by reversed phase HPLC. Finally, the isolated zones obtained by the reversed phase HPLC were analyzed with an amino acid analyzer in order to identify the amino acid substitution involved. 
5.1 Tryptic Digestion; 1solation of Peptides; Amino Acid Analysis. Five to $10 \mathrm{mg}$ of the $\alpha$ chain was dissolved in $10 \mathrm{ml}$ water $+0.15 \mathrm{ml} 10 \%$ acetic acid, and digested (under constant stirring for 6 hours at room temperature) with TPCK-trypsin (Worthington, Freehold, N.J., USA) at pH 8.5-8.9. Next, the $\mathrm{pH}$ of the clear supernatant of the $\alpha$ chain digest was adjusted to 2.5-3.0, whereafter the solution was lyophilized. Two to $3 \mathrm{mg}$ digest was dissolved in $100 \mu$ of 10 \% acetic acid and centrifuged for 10 minutes at $3600 \mathrm{rpm}$, and $1-1.5 \mathrm{mg}$ was applied to the reversed phase HPLC columns (15). The column used was a $C_{18}$ uBondapak (part \$27324, Waters Associates, Milford, MA, USA) and the chromatogram was developed with an acetonitrile- $\mathrm{NH}_{4}$ acetate gradient, $\mathrm{pH} 5.7$, as detailed in the quoted reference. Fractions were measured at $220 \mathrm{~nm}$. The reagents were analytical grade and were pre-filtered through a millipore type $H A 0.45 \mu \mathrm{m}$ filter. All solvents were degassed and sonicated before use. The isolated peptides were dried under nitrogen and part was hydrolyzed in $6 \mathrm{M} \mathrm{HCl}$ at $110^{\circ} \mathrm{C}$ for 24 hours. The resulting hydrolysate was analyzed with a fully automated Waters Pico-Tag amino acid analyzer.

\section{DNA ANALYSES}

6.1 Isolation of Human Genomic DNA From Blood. DNA was isolated from white blood cells essentially by the method of Poncz et al (16). About 5-10 $\mathrm{ml}$ blood was washed three times with $30-40 \mathrm{ml}$ of $1 \mathrm{x}$ (times) reticulocyte saline ( $140 \mathrm{mM} \mathrm{NaCl}, 4 \mathrm{mM} \mathrm{KCl}, 6.8 \mathrm{mM} \mathrm{MgCl} 2$ ) and centrifuged at $2500 \mathrm{~g}$ for 15 minutes at $4^{\circ} \mathrm{C}$. The red blood cells were hemolyzed by adding $10 \mathrm{ml}$ of a freshly prepared solution containing $131 \mathrm{mM} \mathrm{NH} 4 \mathrm{Cl}$ and $0.9 \mathrm{mM}\left(\mathrm{NH}_{4}\right)_{2} \mathrm{CO}_{3}$, $\mathrm{pH}$ 6.5, for 10 minutes at room temperature. The white cells were collected by centrifugation at $2500 \mathrm{~g}$ for 15 minutes at $4^{\circ} \mathrm{C}$ and the supernatant (hemolysate) was carefully removed and saved for $\mathrm{Hb}$ analysis (storage at $-20^{\circ} \mathrm{C}$ ). This was was repeated and the pellet (mainly white blood cells) was resuspended in $5 \mathrm{ml}$ STE solution $(0.1 \mathrm{M} \mathrm{NaCl}, 0.05 \mathrm{M}$ Tris- $\mathrm{HCl}, \mathrm{pH} 7.4,1 \mathrm{mM}$ EDTA). One ml of $10 \%$ SDS and $0.2 \mathrm{ml}$ of proteinase $K(100 \mu \mathrm{g}$ in $10 \mathrm{mM}$ Tris$\mathrm{HCl}, \mathrm{pH} 7.5$ ) were added and the cell suspension was incubated at $37^{\circ} \mathrm{C}$ for 12-24 hours without shaking. Deproteination was accomplished with an equal volume of phenol (after saturation with $20 \mathrm{mM}$ Tris, $\mathrm{pH} 8.0$, containing $0.1 \%$ hydroxyquinoline). The mixture was shaken gently for 30 minutes at room temperature. After centrifugation at $2500 \mathrm{~g}$ for 15 minutes at $4^{\circ} \mathrm{C}$, the aqueous phase was transferred into a new tube and the procedures were repeated. Next, an equal volume of a mixture of chloroform with isoamilyalcohol (in a 24 to 1 ratio) was added and the mixture was shaken gently for 10 minutes at room temperature. After 15 minutes centrifugation at $2500 \mathrm{~g}$ the aqueous phase was mixed with 5 volumes of 95\% ethanol in a plastic flask. After gently mixing, the DNA precipitate was recovered with the broken end of a sterile Pasteur pipette. The DNA was washed twice with 70\% ethanol (to remove any residual phenol or salt) and dried in vacuum. The pellet was dissolved by incubating in $1 \mathrm{ml}$ of TE $(1 \mathrm{mM}$ Tris- $\mathrm{HCl}, \mathrm{pH}$ 7.5, $1 \mathrm{mM}$ EDTA) overnight. The concentration of the DNA was determined from its extinction coefficient at a wavelength of $260 \mathrm{~nm}\left(A_{260}\right)$. An O.D. of 1 corresponded to approximately $50 \mu \mathrm{g} / \mathrm{ml}$ of DNA. The DNA was stored at $4^{\circ} \mathrm{C}$. 


\section{GENE MAPPING}

The various forms of $\alpha$ - and $\beta$-thal, caused by a deletion, are usually studied by gene mapping. Depending upon the type of deletion expected $\alpha$, $\beta, \delta \beta$, or $\gamma, \delta, \beta)$ various restriction enzymes and probes are used for the identification. The procedure of Southern (17) as modified by Blattner et al (18) was followed. Five $\mu g$ of genomic DNA was digested for 3 hours at $37^{\circ} \mathrm{C}$ with 20 units of restriction enzyme, using buffer conditions specified by the suppliers. The DNA fragments were separated by electrophoresis on a $0.8 \%$ agarose gel using DNA digested with Hind III as a size marker. The gel buffer system (TEA; $0.04 \mathrm{M}$ Tris-acetate, $0.002 \mathrm{M}$ EDTA) was the same for all agarose gels. The DNA in the gel was stained with ethidium bromide $(0.5 \mathrm{\mu g} / \mathrm{ml})$ and photographed under UV light. The DNA was denatured by soaking the gel in $0.5 \mathrm{M} \mathrm{NaOH}-1.5 \mathrm{M} \mathrm{NaCl}$ solution for 1 hour and neutralized with a solution containing $3 \mathrm{M} \mathrm{NaCl}, 1.5 \mathrm{M}$ Tris, pH 7.0, for 90 minutes. The DNA was transferred to a nitrocellulose membrane (BA 85, Schleicher and Schuell,

method of Southern (17) using $20 \times$ SSC (1X SSC: $15 \mathrm{mM}$ sodium citrate, $150 \mathrm{mM}$ $\mathrm{NaCl}, \mathrm{pH} \mathrm{7.0)}$. The DNA was fixed on the nitrocellulose membrane by incubation at $80^{\circ} \mathrm{C}$ for 2 hours in a vacuum. In order to perform the hybridization experiments, the nitrocellulose membrane was soaked in $68^{\circ} \mathrm{C}$ 6X SSC plus Denhardt's solution ( $6 X$ SSC containing $0.2 \%$ sterile BSA, $0.02 \%$ Ficoll, 0.02\% polyvinyl pyrrolidone (PVP), $0.5 \%$ SDS) for 10 minutes and prehybridized in about $10 \mathrm{ml}$ of $1 X$ Flavell solution ( $3 X$ SSC $+0.1 \%$ SDS + $20 \mathrm{mM}$ phosphate buffer, $\mathrm{pH} 6.0$, $0.2 \%$ PVP) containing $0.2 \%$ nuclease-free BSA and $50 \mu \mathrm{g} / \mathrm{ml}$ denatured sonicated salmon sperm DNA for about 2 hours at $68^{\circ} \mathrm{C}$. The membrane was hybridized by adding $1 \times 10^{6} \mathrm{cpm} / \mathrm{ml}$ of heat denatured probe and incubating at $68^{\circ} \mathrm{C}$ for $16-24$ hours. The non-hybridized (unbound) probe was removed by washing the membrane twice with $3 X$ SSC + $0.5 \%$ SDS solution at $68^{\circ} \mathrm{C}$ with shaking, for 30 minutes each time. The membrane was monitored with a Geiger counter to check if the washing was sufficient (few counts above background). In some instances additional washing with $1 \times$ SSC $+0.5 \%$ SDS solution was necessary. The membrane with the hybridized fragments was exposed to Kodak. X-Omat film at $-70^{\circ} \mathrm{C}$ for 72 hours. The film was developed using a Kodak $X$-ray film processor and the positions and sizes of particular sequences of DNA were evaluated.

\section{REHYBRIDIZATION OF SOUTHERH BLOT MEMBRANES}

Membrane rehybridization was accomplished by first stripping the membranes in a 2 to $3^{\prime \prime}$ deep plastic container with a $0.5 \mathrm{M} \mathrm{NaOH}-1.5 \mathrm{M} \mathrm{NaCl}$ solution under careful shaking for 4 minutes. The membranes were rinsed three times with distilled water and neutralized for 4 minutes with $3 \mathrm{M}$ $\mathrm{NaCl}-1.5 \mathrm{M}$ Tris- $\mathrm{HCl}$, $\mathrm{pH} 7.0$. Rehybridization was as described for the hybridization procedure.

\section{PROBES}

9.1 Gene kapping Probes. The following probes were used to identify specific restriction fragments: a) the $\gamma$ IVS-II probe; a 457 bp fragment obtained by a Bam HI-Pvu II double digestion of the plasmid pr0.46pB that 
contains the $5^{\prime}$ region of the large IVS of the $G_{\gamma}$ - and $A_{\gamma}$-globin gene. b) The BIVS-II probe; a $1.2 \mathrm{~kb}$ fragment obtained by a Bam HI-Eco RI double digestion of plasmid pṕlvs-ll that contains the large IVS of the $\hat{\beta}-g l o b i n$ gene. c) The SIVS-II probe; a $1.0 \mathrm{~kb}$ fragment generated by an Eco RI-Bam HI double digestion of the plasmid Pst $1-2.3 \mathrm{~kb} \delta$ that contains the $\delta I V S-1]$. d) The $P R K$ probe; a $0.8 \mathrm{~kb}$ fragment obtained by a double digestion of the plasmid PRK 28 with Eco RI-Big II that is located $17 \mathrm{~kb} 3^{\prime}$ to the $\beta$-globin gene. e) The $\alpha$ probe; a $1.5 \mathrm{~kb}$ fragment obtained by a Bam HI digestion of the $p B R \alpha l$ probe. f) The 3 probe; a $1.9 \mathrm{~kb}$ fragment generated by digestion of the pBRzplasmid with Hinf 1 .

\section{OLIGONUCLEOTIDE DESIGN AND SYNTHESIS}

01 igonucleotides employed as amplification and sequencing primers and dot-blot hybridization probes were prepared on an Applied Biosystems $380 \mathrm{~B}$ DNA synthesizer. The primers were purified on a Sephadex G-50 column; the eluate was vacuum dried and dissolved in $\mathrm{TE}$ buffer (1 mM Tri-HC), $\mathrm{pH} 7.5$, 1 mM EDTA).

\section{PCR}

The identification of the point mutations leading to $\beta$-thal was initially achieved by the laborious procedures of cloning and sequencing. In recent years, the development of the PCR procedure and its application to the study of $\beta$-thal mutations has greatly facilitated the identification of $\beta$-thalassaemias (19-21).

11.1 Principle. PCR is an in vitro technique based upon the enzymatic amplification of a specific DNA fragment flanked by two synthetic oligonucleotide primers complementary to the opposite strands of the fragment of interest. Heat denaturation of double stranded DNA, followed by annealing of the primers to their complementary strands and extension of the annealed primers with DNA polymerase, leads to the amplification of the DNA sequences between the primers. Repeated cycles of denaturation, annealing, and extension results in an exponential accumulation of the target fragment (106-fold) in several hours. The use of heat-stable DNA polymerase from Thermus Aquaticus (Taq polymerase) greatly increases the efficiency of the procedure. The procedure can be automated by the use of a programmable Thermal Cycler (Perkin-Elmer-Cetus, Emeryville, CA, USA). The reaction is carried out in a sterile $0.5 \mathrm{ml}$ Eppendorf tube.

11.2 Procedure. The mixture is first heated to $95^{\circ} \mathrm{C}$ to separate the strands of genomic DNA $\left(7\right.$ minutes) and then cooled to $55^{\circ} \mathrm{C}$ for 5 minutes to allow the annealing of the primers to the separated strands of genomic DNA. Some 2-5 units of Taq polymerase is added, over-layered with mineral oil to prevent evaporation, and then the tubes are centrifuged. The Thermal Cycler is programed for $30-35$ cycles of denaturation at $95^{\circ} \mathrm{C}(1.5$ minutes), annealing at $55^{\circ} \mathrm{C}\left(1.5\right.$ minutes), and extension at $72^{\circ} \mathrm{C}$ ( 3 minutes). The B-globin gene is amplified in two fragments: a $5^{t}$ segrnent between nt 140 and IVS-II-70 (700 bp) and a $3^{\prime}$ segment between IVS-II-547 and 200 bp 3' to the $\beta$ gene $(500 \mathrm{bp})$. Following amplification, an aliquot $(5 \mu 1)$ of the 
sample is run on a 0.8 agarose minigel and stained with ethidium bronide along with Hind III digested DNA as a marker, to detect the amplified band under UV light (Fig. 2.3). Samples are kept at $4^{\circ} \mathrm{C}$ until analyzed.

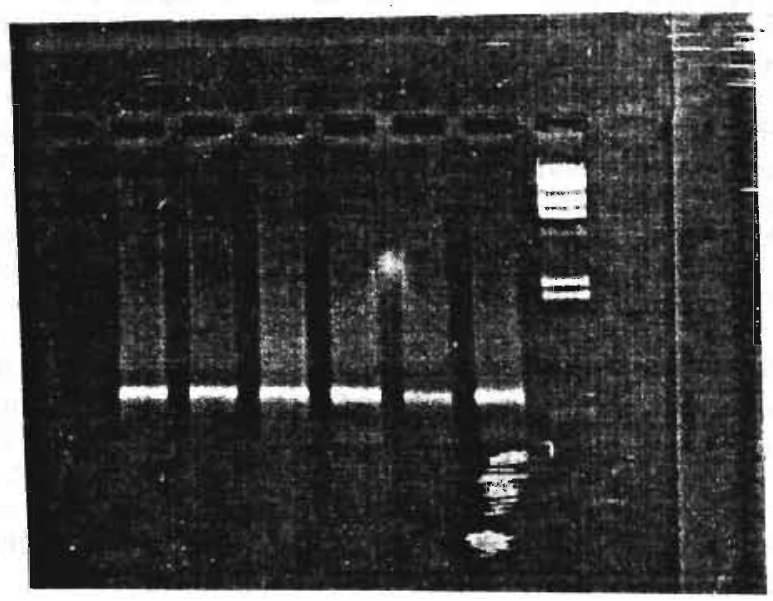

FIG. 2.3 PCR product analys is of a 700 bp fragment in the $\beta$-globin gene. A Hind III digested $\lambda$ phage size marker is applied to the far right of the $1.5 \%$ agarose gel.

\section{DOT-BLOT ANALYSIS}

Identification of $\$$-globin gene mutations can be made by dot-brot hybridization. A small aliquot $(40 \mu l)$ of amplified ONA is alkali denatured by adding $320 \mu l$ water and $40 \mathrm{ml}$ denaturing solution $10.4 \mathrm{~N} \mathrm{NaOH}$ with $\left.25 \mathrm{mMN} \mathrm{Na}_{2} \mathrm{EDTA}\right)$ and then applied in duplicate under vacuum on to a zeta probe nylon membrane using a spotting device (Bio-Dot, Bio-Rad Laboratories, ). Allele-specific oligonucleotide probes $(19-20 \mathrm{nt})$ are synthesized by an Applied Biosystems DNA synthesizer. A probe with a normal sequence and a second with the substitution (located in the centre of the probe) is required for each mutation. Both mutant and normal probes are $5^{\prime}$ end labelled with $\gamma$-32P-ATP (approximately $7000 \mathrm{Ci} / \mathrm{mM}$, $160 \mathrm{mCi} / \mathrm{ml}$ ) by $\mathrm{T}_{4}$ polynucleotide kinase for 1.5 hours at $37^{\circ} \mathrm{C}$ [United States Biochemical (USB) Corporation, labelled probes are separated from free 32 P-ATP on either a sephadex G-50 or a Nensorb (NEN) column (NEN DuPont, The zeta probe nylon membrane is incubated for 30 minutes at $65^{\circ} \mathrm{C}$ in a sealed plastic bag with a prehybridization solution (pre-hybridization buffer: $5 X$ SSPE, 5X Denhardt's, $0.5 \%$ SDS; where $20 X S S P E=3.6 \mathrm{M} \mathrm{NaCl}, 20 \mathrm{mM} \mathrm{NaH} 2 \mathrm{PO}_{4}, 20 \mathrm{mM}$ $\mathrm{Na}_{2}$ EDTA, pH 7.4; $50 \mathrm{X}$ Denhardt's $=1 \%$ Ficoll, 1\% PVP, 1\% BSA). Next, the radio-labelled probe is added $\left(30-100 \times 10^{6} \mathrm{cpm} / \mathrm{bag}\right)$, and hybridization occurs for 1.5 hours in a circulating water bath. The hybridization temperature varies for each probe, depending upon the $\mathrm{Tm}$ of the probes, which can be calculated from the nt content according to the formula: $T \pi=4 \times$ $(G+C)+2 \times(A+T)$. Following hybridization, the membrane is washed twice for 10 minutes with SSPE $0.1 \%$ SDS at room temperature. The membranes 
are then washed at $42^{\circ} \mathrm{C}$ for 20 minutes in tetramethyl ammomium chloride (TMAC), followed by a second TMAC washing at $58^{\circ} \mathrm{C}$ for 30 minutes (22). After washing, the membranes are autoradiographed by exposure to Kodak XAR-5 $x$-ray film for 2-12 hours.

12.1 Interpretation. The probe will hybridize only when there is a perfect match between the sequence of amplified DNA and the probe. Single base changes will prevent hybridization and therefore, will not result in the visualization of a dark spot on autoradiography. Thus, DNA from a normal individual will only hybridize to the normal probe, while DNA from an individual homozygous for a certain mutation will only hybridize to the mutant probe and not to the normal probe. A heterozygote will show hybridization with both the normal and mutant probes. The detection of a mutation in amplified DNA by dot-blot hybridization to oligonucleotide probes is shown in different chapters of this thesis.

The choice of probes for mutant alleles is dictated by the spectrum of $\beta$-thal mutations in a given population. In some populations, a few mutations account for the majority of $\beta$-thal alleles. In other populations, ₹-thal is more heterogeneous and even after hybridization to a large number bf mutant probes, a significant portion of $\beta$-thalassaemias remain unidentified. The identification of mutations on these unknown chromosomes can be achieved by sequencing amplified DNA (23-26).

\section{DNA SEQUENCING}

13.1 Synthesis of Single Strand DHA Sequencing. Amplification of single strand DNA occurred in a similar fashion as described for double strand DNA amplification, except for the use of an asymetric ratio (50 to 1) of the two primers used to generate single strand DNA. In order to obtain optimal data it was considered advisable to limit the size of the fragments to be amplified to less than 800 bp. After amplification, the amplified DNA was purified by adding an equal volume of $2.5 \mathrm{M}$ ammonium acetate and two volumes of ice-cold $100 \%$ ethanol. The mixture was left at room temperature for 5 minutes, centrifuged for 10 minutes in a microcentrifuge, and the pellet was then washed twice with $70 \%$ ethanol. The DNA precipitate was air dried and finally dissolved in $10 \mu$ l of TE buffer (10 mM Tris-HCl, $\mathrm{pH} 8.0,0.1 \mathrm{mM}$ EDTA). One $\mu 1$ of the DNA solution was electrophoresed on a $1.5 \%$ agarose gel to monitor the recovery.

13.2 Single Strand DNA Sequencing. DNA sequencing was carried out by the dideoxy method of Sanger et al (27) using a sequenase kit from USB corporation. The dideoxy sequence analysis is a three-step procedure: a) annealing, b) labelling, and c) termination.

13.2a Annealing template and primer. The following reagents were combined in an Eppendorf tube: $1 \mu 1$ of primer (100 pmols), $2 \mu 1$ of sequencing buffer (200 $\mathrm{mM}$ Tris, $\mathrm{pH} 7.5,100 \mathrm{mM} \mathrm{MgCl} 2,250 \mathrm{mM} \mathrm{NaCl})$, and $7 \mu 1$ of DNA sample obtained by the single strand DNA amplification procedure. If a smaller volume of DNA solution was used, the balance was made up with distilled water. The capped tube was incubated at $65-70^{\circ} \mathrm{C}$ for 3 minutes and then placed in an ice-bath. 
13.2b Labelling reaction. For standard reactions (reading sequences up to 500 bp or 50 bp from the primer) the labelling mix $(7.5 \mu \mathrm{M}$ dGTP, $7.5 \mu M$ dCTP, $7.5 \mu M$ dTTP) was diluted 5-fold with distilled water. The following was added to the annealed template primer: $1 \mu l$ of DTT $(0.1 \mathrm{M})$, $2 \mu l$ of the diluted mix, and $1 \mu l$ of $\left[\alpha^{35 \mathrm{~S}}\right]$ dATP $(800 \mathrm{ci} / \mathrm{mmol}, 10.0 \mathrm{mCi} / \mathrm{ml}$; DuPont)]. After $1 \mu$ l of sequenase was diluted with $8 \mu l$ of TE buffer, $2 \mu 1$ of the diluted sequenase was added to the reaction mixture and incubated at room temperature for 3 minutes.

13.2c Termination reaction. Two and one-half $\mu l$ of each termination

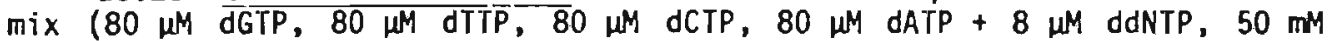
$\mathrm{NaCl}$ ) were placed in four fresh tubes labelled as $A, G, T$, and $C$. When the labelling reaction was complete, $3.5 \mu 1$ of the reaction mixture was transferred to each labelled tube. They were centrifuged for a few seconds to ensure mixing, and the incubation was continued at $37^{\circ} \mathrm{C}$ for 5 minutes. Four $\mu$ ) of stop solution ( $9 \%$ formamide, $20 \mathrm{mM}$ EDTA, $0.05 \%$ bromophenol blue, $0.05 \%$ xylene cyanol FF) was added to each of the termination mixtures. When a gel was ready for loading, the samples were heated to $80^{\circ} \mathrm{C}$ for 2 minutes and $3.5 \mu$ l of sample was loaded.

\section{ENZMES AND CHEMICALS}

Restriction enzymes were obtained from Bethesda Research Laboratories (Bethesda, MD), Boehringer Mannheim (Indianapolis, IN), International Biotechnology, Inc. (New Haven, CT), and New England Biolabs (Beverly, MA). Nick-translation kits were purchased from Amersham (Arlington Heights, IL), and BRL ( ) Crystallized phenol for DNA isolation was obtained from Fisher (Norcross, GA), and redistilled before use. Taq DNA polymerase was obtained from Perkin Elmer Cetus (Norwalk, CT).

\section{REFERENCES}

1. Basset, P., Beuzard, Y., Garel, M.C., and Rosa, J.: Isoelectric focusing of human hemoglobin; its application to screening, to characterization of 70 variants and to the study of modified fractions of nomal hemoglobins. Blood, 51:971, 1978.

2. Betke, K., Marti, H.R., and Schlicht, I.: Estimation of small percentages of foetal haemoglobin. Nature, 184:1877, 1959.

3. Singer, K., Chernoff, A.I., and Singer, L.: Studies on abnormal hemoglobins. I. Their demonstration in sickle cell anemia and other hematologic disorders by means of alkali denaturation. Blood, $6: 413$, 1951.

4. International Committee for Standardization in Haematology. Recommendations for foetal haemoglobin reference preparation and foetal haemoglobin determination by the alkali denaturation method. $\mathrm{Br}$. $\mathrm{J}$. Haematol., 42:133, 1979.

5. Huisman, T.H.J. and Jonxis, J.H.P.: The Hemoglobinopathies Techniques of Identification, Clinical and Biochemical Analysis, Vol. 6, pages 120, 722, Marcel Dekker, Inc., New York, 1977.

6. Schroder, W.A. and Huisman, T.H.J.: The Chromatography of Hemoglobin. Clinical and Biochemical Analysis, Vol. 9, Marcel Dekker, Inc., New York, 1980. 
7. Huisman, T.H.J.: Separation of hemoglobins and hemoglobin chains by high-performance liquid chromatography. J. Chromatogr., 418:277, 1987.

8. Kutlar, F., Gu, L.H., Hu, H., and Huisman, T.H.J.: Quantitation of Hb Bart's, Hb H, Hb Portland-I, Hb Portland-II, and Hb Constant Spring by anion exchange high-performance liquid chromatography. J. Chromatogr., 487:265, 1989.

9. Wilson, J.B. and Huisman, T.H.J.: Detection and quantitation of normal and abnormal hemoglobins in adults and newborn by high performance liquid chromatography, in The Hemoglobinopathies, edited by T.H.J. Huisman, Methods in Hematology, Vol. 15, page 32, Churchill Livingstone, Edinburgh, 1986.

10. Wilson, J.B.: Separation of human hemoglobin variants by HPLC, in HPLC of Biological Macromoles: Methods and Application, edited by $K$. Gooding and F. Regnier, page 1, Marcel Dekker, Inc., New York, 1989.

11. Wilson, J.B., Wrightstone, R.N., and Huisman, T.H.J.: A rapid cationexchange high performance liquid chromatographic procedure for the separation and quantitation of hemoglobin variants in cord blood samples. J. Lab. Clin. Med., 108:138, 1986.

12. Shelton, J.B., Shelton, J.R., and Schroeder, W.A.: High performance liquid chromatographic separation of globin chains on a large-pore $C_{4}$ column. J. Liq. Chromatogr., 7:1969, 1984.

13. Kutlar, F., Kutlar, A., and Huisman, T.H.J.: Separation of normal and abnormal hemoglobin chains by reversed-phase high-performance liquid chromatography. J. Chromatogr., 357:147, 1986.

14. Clegg, J.B., Naughton, M.A., and Weatherall, D.J.: Abnormal human haemoglobins. Separation and characterization of the $\alpha$ and $\beta$ chains by chromatography and the determination of two new variants, Hb-Chesapeake and $\mathrm{Hb}-\mathrm{J}$ (Bangkok). J. Mol. Biol., 19-91, 1966.

15. Wilson, J.B., Lam, H., Pravatmuang, P., and Huisman, T.H.J.: Separation of tryptic peptides of nomal and abnormal $\alpha, \beta, \gamma$, and $\delta$ hemoglobin chains by high-performance lqiud chromatography. J. Chromatogr., 179:271, 1979 .

16. Poncz, M., Solowiejczyk, D., Harpel, B., Mory, Y., Schwartz, E., and Surrey, S.: Construction of human gene libraries from small amounts of peripheral blood: Analysis of $\beta$-like globin genes. Hemoglobin, $6: 27,1982$.

17. Southern, E.M.: Detection of specific sequences among DNA fragments separated by gel electrophoresis. J. Mol. Biol., 98:503, 1975.

18. Blattner, F.R., Blechl, A.E., Dennistron-Thomson, K., Faber, H.E., Richards, J.E., Slightom, J.L.. Tucker, P.W., and Smithies, O.: Cloning of human fetal $\gamma$ globin and mouse $\alpha$-type globin DNA: Preparation and screening of shotgun collections. Science, 202:1284, 1978.

19. Saiki, R.K., Gelfand, D.H., Stoffel, S., Scharf, S.J., Higuchi, R., Horn, G.T., Mullis, K.B., and Erlich, H.A.: Primer directed enzymatic amplification of DNA with a thermostable DNA polymerase. Science, 239:487, 1988.

20. Diaz-Chico, J.C, Yang, K.G., Yang, K.Y., Efremov, D.G., Stoming, T.A., and Huisman, T.H.J.: The detection of $B$-globin gene mutations in $\bar{P}-$ thalassemia using oligonucleotide probes and amplified DNA. Biochim. Biophys. Acta, 949:43, 1988.

21. Kazazian, H.H., Jr. and Boehm, C.D.: Molecular basis and prenatal diagnosis of $\beta$-thalassemia. Blood, 72:1107, 1988. 
22. Wood, W.G., Gitschia, J., Lasky, L.A., and Lawn, R.N.: Base composition independent hybridization in tetramethylammonium chloride: A method for oligonucleotide screening of highly complex gene libraries. Proc. Natl. Acad. Sci. USA, 82:1585, 1985.

23. Codrington, J.F., Li, H-W., Kutlar, F., Gu, L-H., Ramachandran, M., and Huisman, T.H.J.: Observations on the levels of $H b A_{2}$ in patients with different $\beta$-thalassemia mutations and a $\delta$ chain variant. Blood, $76: 1246,1990$.

24. Codrington, J.F., Kutiar, F., Harris, H.F., Wilson, J.B., Stoming, T.A., and Huisman, T.H.J.: Hb $A_{2}$-Wrens or $\alpha_{2} \delta_{2} 98$ (FG5)Var-MMet, an unstable $\delta$ chain variant identified by sequence analysis of amplified DNA. Biochim. Biophys. Acta, 1009:87, 1989.

25. Stoming, T.A., Stoming, G.S., Lanclos, K.D., Fei, Y.J., Altay, 6., Kutlar, F., and Huisman, T.H.J.: An Ar type of nondeletional hereditary persistence of fetal hemoglobin with a $B C$ mutation at position -175 to the Cap site of the Ay globin gene. Blood, 73:329, 1989.

26. Li, H-W., Codrington, J.F., Schiliro, G., Wadsworth, L.D., Beris, Ph., Adekile, A.D., and Huisman, T.H.J.: The usefulness of sequence analysis of amplified DNA for the identification of $\delta$ chain variants. Hemoglobin, 15:77, 1991.

27. Sanger, F., Nicklen, S., and Coulson, A.R.: DNA sequecing with chainterminating inhibitors. Proc. Natl. Acad. Sci. USA, 74:5463, 1977. 
CHAPTER 3

STRUCTURAL VARIANTS IN THE SURINAM POPULATION 
CHAPTER $3 a$

HB CHAD OR $\alpha_{2} 23$ (B4)GLUALYS 2 OBSERVED IN MEMBERS OF A SURINAM FAMILY IN ASSOCIATION WITH $\alpha$-THALASSEMIA-2 AND WITH HB $S$ (Adapted from: Hemoglobin, 13:543-556, 1989) 
HB CHAD OR $\alpha_{2}$ 23(B4)GLLLYY $\beta_{2}$ OBSERVED IN MCMBERS OF A SURINAM FAMILY IN ASSOCIATION WITHQ -TIMLASSEMIA-2 ANO KITH HB S

J.F. Codrington1,2, F.A. Codrington2, J.H. Wisse², J.B. Hilsonl, B.B. Webberl, S.C. Nongl, and T.H.J. Huisnanl

1 Departnent of Cell and Molecular Biology Laboratory of Protein Chemistry

Medical College of Georgia

Augusta, GA 30912-2100, U.S.A.

2 Academisch Ziekenhuis

Paramaribo, Suriname

(Adapted from: Hemoglobin, 13:543-556, 1989)

\section{ABSTRACT}

Three different haemoglobinopathies, i.e. Hb S, Hb Chad $[\alpha 23(B 4) G l u \rightarrow$ Lys], and $\alpha$-thal-2 (-3.7 kb) have been observed in eight members of a family from Surinam. The propositus had all three abnormalities, while her mother and four of her half-brothers had $\mathrm{Hb}$ Chad together with an $\alpha$-thal-2 heterozygosity or homozygosity. Gene mapping and dot-blot analysis of amplified DNA identified a $G>A$ mutation in codon 23 of the $\alpha 2 \alpha_{1}$ )hybrid gene resulting in the Glülys substitution. The quantity of the $\alpha$-Chad chain averaged $31.5 \%$ in its carriers with an additional $\alpha$-thal-2 heterozygosity [- $\alpha$ Chad $(-3.7 \mathrm{~kb}) /-\alpha(-3.7 \mathrm{~kb})]$. These quantities are considerably higher than those reported for families from Chad, China, and Japan; the low levels of 14.5$24 \% \mathrm{Hb}$ Chad in members of these families suggest a mutation on a chromosome

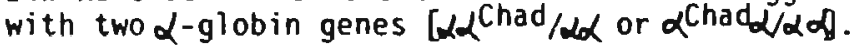

\section{INTRODUCTION}

The $\alpha$ chain variant $\mathrm{Hb}$ Chad or $\alpha_{2} 23(B 4) G 1 u \rightarrow L y s \beta_{2}$ was discovered in 1968 by Boyer et al (1) in a family living in the Republic of Chad, and has since been found in two Chinese families $(2,3)$, and in a Japanese family (4). The quantity present in heterozygotes was reported to be about $16 \%$ in the chad family, 14.5\% in one Chinese family (2), and nearly 24\% in a Japanese male (4). In this communication we describe the occurrence of the same variant in six members of a Surinam family including one with an additional $\mathrm{Hb} S$ heterozygosity; the quantity of $\mathrm{Hb}$ Chad in heterozygotes was considerably higher than reported for the other subjects. 
3.1 Blood Samples. These were collected in vaculainers with EDTA as anticoagulant and shipped by a special air delivery service from Paramaribo, Surinam to Augusta, GA; the total travel time was less than 48 hours. Informed consent was obtained.

3.2 Hb Analysis. Haematological data nere collected with an automated cell counter. Red cell lysates were analyzed by IEF (5) and by cation exchange HPLC $(6,7)$. The latter method made use of a 4.6 (ID) $x 200 \mathrm{~mm}$ PolyCAT A WCX (5 nm) column (Custom LC, InC., Houston, TX) and two developers. Developer A contained $35 \mathrm{mM}$ Bis-Tris, $3 \mathrm{mM} \mathrm{NH}_{4}$ acetate, $100 \mathrm{mg} \mathrm{KCN}$ per $100 \mathrm{ml}(\mathrm{pH} \mathrm{6.47)}$, and developer C contained $70 \mathrm{mM}$ Bis-Tris, $33.7 \mathrm{mM}$ $\mathrm{NH}_{4}$ acetate, $300 \mathrm{mM}$ Na acetate, $100 \mathrm{mg} \mathrm{KCN}$ per $1000 \mathrm{ml}$ (pH 7.0). A gradient was applied between 75\% developer $A+25 \%$ developer $C$ as the initial solvent, and $100 \%$ developer $C$ as the final solvent, at a flowrate of $0.8 \mathrm{ml} / \mathrm{min}$ over a period of 95 minutes. Quantitative data were obtained with the same HPLC procedure.

3.3 Structural Analysis. A larger quantity of $\mathrm{Hb} X(=\mathrm{Hb}$ Chad) was isolated by preparative DEAE-cellulose chromatography ( 8 ). The $\alpha^{X}$ and $\beta$ chains were separated on a column of CM-cellulose by the method of clegg et al (9). Peptides from a tryptic digest of the $\alpha^{X}$ chain were separated by reversed phase MPLC (10); one isolated zone that contained two peptides was rechromatographed on a similar column but with different elution solvents (11). The determination of the amino acid composition of the isolated tryptic peptides was with a Pico-Tag amino acid analysis system (Waters; see manufacturers manual).

3.4 DNA Analysis. DNA was isolated from white cells by the method of Poncz et al (12). Gene mapping followed the same procedures used in earlier studies $(13,14)$; hybridization was with the $\alpha$ probe. Amplification of the $\alpha 2-$ and $\alpha 1-g l o b i n$ genes with the Taq enzyme followed the procedures of Saiki et al $(15,16)$ with primers specific for these genes $(17,18)$. Hybridization was with $32 p$-labelled oligonucleotides with compositions as reported elsewhere in this paper. Primers and probes were synthesized with the Applied Biosystems Model 380B DNA synthesizer.

\section{RESULTS}

The family has a mixed racial background, including Black. While participating in a general survey for the presence of haemoglobinopathies, the propositus, a healthy 30-year-old female, was discovered to have four $\mathrm{Hb}$ components. Subsequently, seven members of her immediate family were also investigated. Fig. 3a.l gives the pedigree as well as the Hb patterns observed by IEF. A major slow-moving variant with a mobility between that of $\mathrm{Hb} A_{2}$ and $H b S$ was present in six members, including the propositus. $\mathrm{Hb} S$ was observed in the propositus and her father, while a third abnormal band (labelled SX) was seen in the red cell lysate of the propositus. Moreover, all subjects with the $X$ component had an additional minor $\mathrm{Hb} \mathrm{X}_{2}$ that suggested $H b X$ was an $\alpha$ chain variant. 

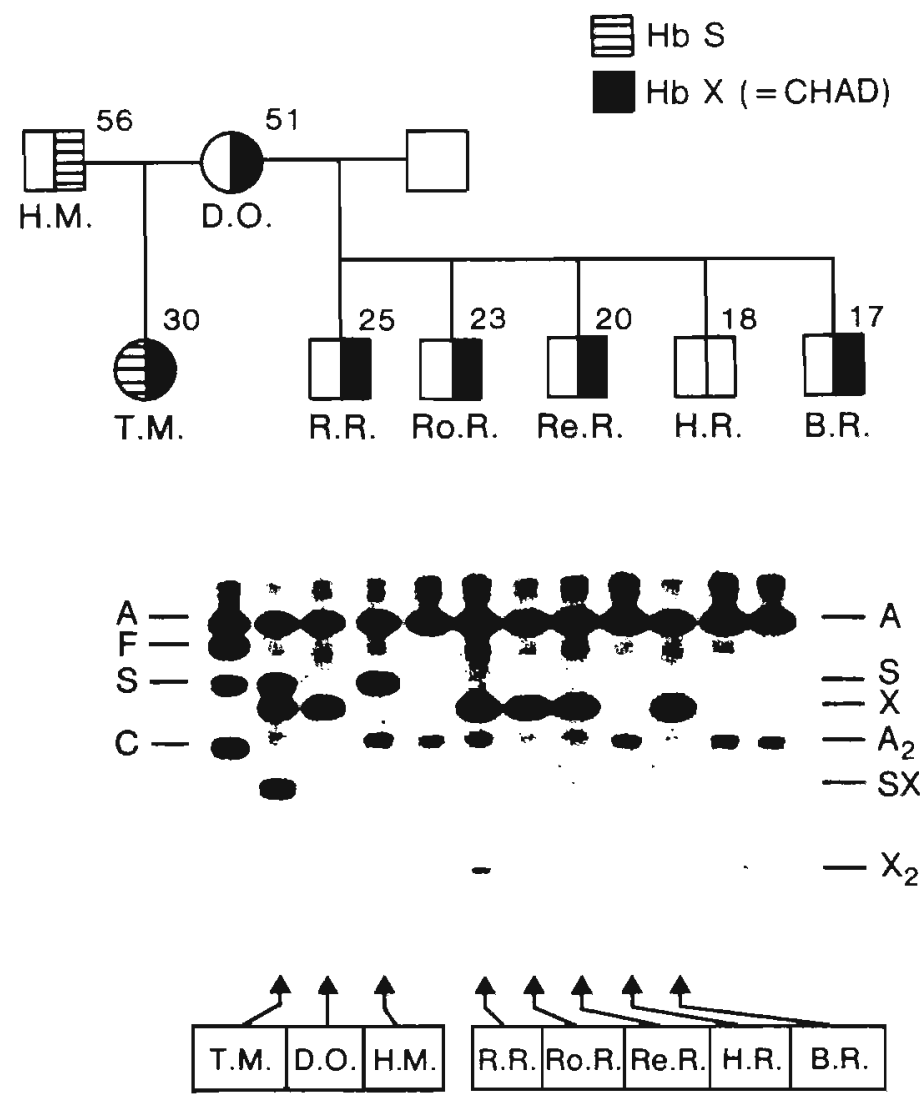

FIG. 3a.1 Pedigree of Family $M$ with $H b S$ and the $\alpha$ chain variant Hb Chad (top). Separation of the Hb by IEF is shown at the bottom.

Chromatographic analysis by cation exchange HPLC gave a complete separation of the various $\mathrm{Hb}$ components (Fig. 3a.2). It also provided quantitative data for the major $(A, S, X, S X)$ and minor $\left(A_{2}, X_{2}\right)$ components seen in the propositus, for $\mathrm{Hb} S$ and $\mathrm{Hb} \mathrm{A}_{2}$ in her father, and for $\mathrm{Hb} X$ and $\mathrm{Hb} \mathrm{X}_{2}$ in the five $\mathrm{Hb} X$ heterozygotes. These data are listed in Table 3a.1 together with the results of the haematological analyses. The five $\mathrm{Hb} x$ heterozygotes fell into two groups: 0.0 . and B.R. had high $H b X$ levels (42.2 and 43.9\%, including $\mathrm{Hb} \hat{X}_{2}$ ) and a distinct microcytosis and hypochromia (MCV 74-71 f1; $M C H$ 21.7-19.4 pg), while the remaining three relatives (R.R., Ro.R, Re.R.) had lower $H b X$ levels $\left(32.1,31.8\right.$, and $31.5 \%$, including $\left.H b X_{2}\right)$ and a less distinct microcytosis and hypochromia (MCV 88-93 fl; $\mathrm{MCH} 25.3-$ $28.5 \mathrm{pg})$. The data for the propositus were similar and her $\mathrm{Hb} X$ level was $31.5 \%$ (including $\mathrm{Hb} \mathrm{X}_{2}$ ) and her $\mathrm{Hb} S$ level was $32 \%$; she had a more distinct microcytosis and hypochromia (MCV $68 \mathrm{fl}$; $\mathrm{MCH} 21.7 \mathrm{pg}$ ) than her relatives with a similar $H b X$ value. The father of the propositus had Hb $S$ trait; his mild anaemia remains unexplained. One half-brother (H.R.) without Hb $X$, had a mild anaemia with a microcytosis and hypochromia comparable to that seen in his mother $(D .0$.$) and his younger brother (B.R.).$ 


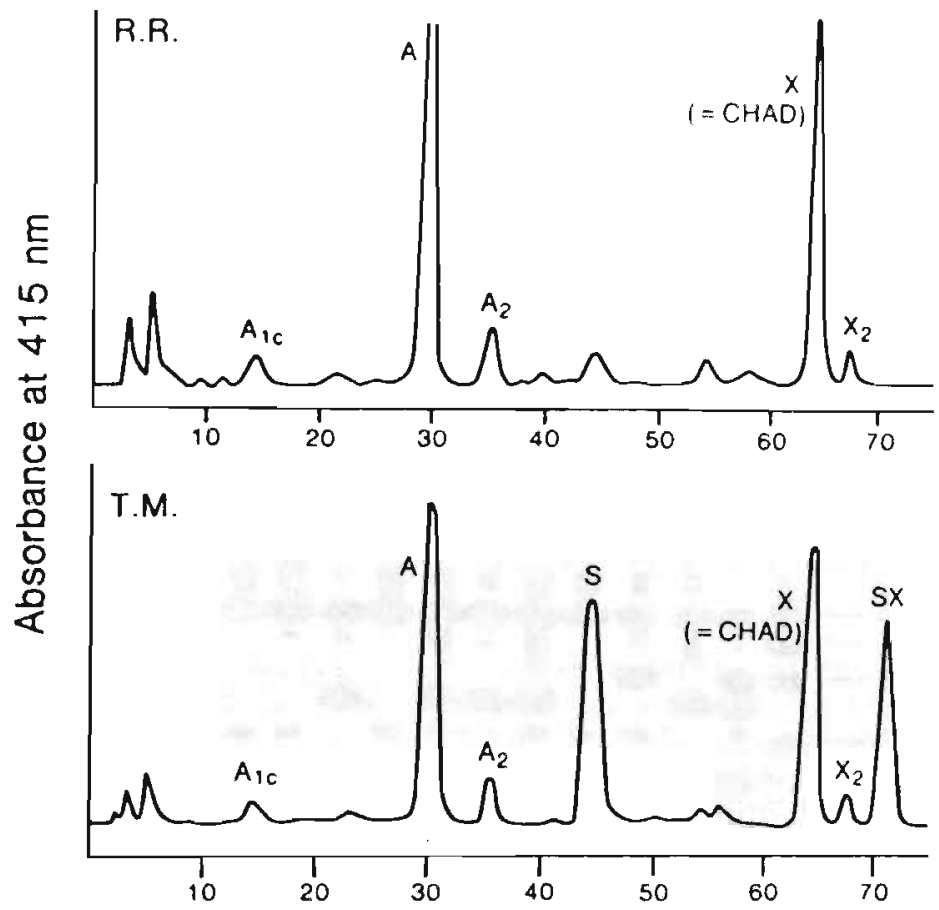

Time in Minutes

FIG. 3a.2 Separation of Hb types by cation exchange HPLC. R.R. is a simple $\mathrm{Hb}$ Chad heterozygote; T.M. is heterozygous for $\mathrm{Hb} S$ and $\mathrm{Hb}$ Chad. $\left(S X=\alpha_{2} x_{\beta 2} S\right)$. See text for methodology.

Structural studies were limited to the analysis of the soluble peptides in a tryptic digest of the $\alpha^{X}$ chain. Fig. $3 a .3$ gives an example of the chromatograms that were obtained. All peptides were recovered except $\alpha T-4$ that was apparently split into two fragments. Peptide $\alpha T-4 A$ eluted ahead of $\alpha T-1$, while $\alpha T-4 B$ eluted together with the double peptide $\alpha T-1,2$; the latter two readily separated upon rechromatography (insert of Fig. 3a.3). Table $3 a .2$ lists the amino acid compositions of $\alpha T-4 A$ and $\alpha T-4 B$. These data readily identified a Gl $\rightarrow$ Lys substitution in position 7 of this peptide or in position 23 of the intact $\alpha$ chain and identified the variant as $H b$ Chad.

Gene mapping analyses involved DNA from all eight members of this family. Data obtained with the enzymes Bam HI and Bgl II are shown in the top section of Fig. 3a.4. Abnormal fragments were observed with both enzymes; only one member (H.M., see pedigree of Fig. 3a.1) had four -globin genes due to the presence of a $-3.7 \mathrm{~kb}$ deletion on one chromosome, while B.R., D.O., and H.R. had only two $\alpha$-globin genes and were homozygous for the $\alpha$-thal-2 $(-3.7 \mathrm{~kb})$ deletion. Subjects B.R. and D.0. are al so heterozygous for $\mathrm{Hb}$ Chad with high levels of the $\alpha X$ chain ( $43 \%)$, indicating that the $\alpha$-Chad mutation is present on an $\alpha$-thal-2 chromosome. 


\begin{tabular}{|c|c|c|c|c|c|c|c|c|}
\hline Subjecta & H.M. & T.M. & D. 0 . & R.R. & Ro. R. & Re.R. & B.R. & H.R. \\
\hline $\begin{array}{l}\text { Sex-Age } \\
\text { Diagnosis }\end{array}$ & $\begin{array}{l}M-56 \\
\text { AS }\end{array}$ & $\begin{array}{l}F-30 \\
S X\end{array}$ & $\begin{array}{l}F-51 \\
A X\end{array}$ & $\begin{array}{l}M-25 \\
A X\end{array}$ & $\begin{array}{l}M-23 \\
A X\end{array}$ & $\begin{array}{l}M-20 \\
A X\end{array}$ & $\begin{array}{l}M-17 \\
A X\end{array}$ & $\begin{array}{l}M-18 \\
A A\end{array}$ \\
\hline $\begin{array}{l}\text { Hb }(g / d)) \\
\operatorname{PCV}(1 / 1) \\
\operatorname{RBC}(1012 / 1) \\
\operatorname{MCV}(f 1) \\
\operatorname{MCH}(\mathrm{pg}) \\
\operatorname{MCHC}(\mathrm{g} / \mathrm{dl})\end{array}$ & $\begin{array}{c}11.6 \\
0.41 \\
4.17 \\
98 \\
27.8 \\
28.3\end{array}$ & $\begin{array}{l}9.2 \\
0.29 \\
4.24 \\
68 \\
21.7 \\
31.7\end{array}$ & $\begin{array}{l}11.8 \\
0.415 \\
5.59 \\
74 \\
21.1 \\
28.4\end{array}$ & $\begin{array}{l}14.9 \\
0.525 \\
6.00 \\
88 \\
28.4 \\
28.4\end{array}$ & $\begin{array}{c}13.2 \\
0.46 \\
5.21 \\
93 \\
25.3 \\
28.7\end{array}$ & $\begin{array}{l}13.7 \\
0.49 \\
5.27 \\
73 \\
26.0 \\
28.0\end{array}$ & $\begin{array}{c}11.3 \\
0.41 \\
5.81 \\
\\
19.4 \\
27.6\end{array}$ & $\begin{array}{l}10.9 \\
0.395 \\
5.40 \\
71 \\
20.2 \\
27.6\end{array}$ \\
\hline 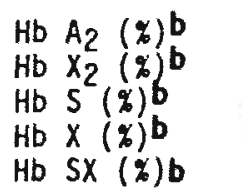 & $\begin{array}{c}3.8 \\
0 \\
37.0 \\
0 \\
0\end{array}$ & $\begin{array}{r}1.9 \\
1.2 \\
21.4 \\
19.7 \\
10.6\end{array}$ & $\begin{array}{l}1.1 \\
1.2 \\
0 \\
41.2 \\
0\end{array}$ & $\begin{array}{l}1.8 \\
1.1 \\
0 \\
31.0\end{array}$ & $\begin{array}{l}1.5 \\
1.0 \\
0 \\
30.8\end{array}$ & $\begin{array}{l}1.5 \\
1.0 \\
0 \\
30.5\end{array}$ & $\begin{array}{l}1.2 \\
1.4 \\
0 \\
42.5\end{array}$ & $\begin{array}{l}2.6 \\
0 \\
0 \\
0 \\
0\end{array}$ \\
\hline $\begin{array}{l}x(x)^{b} \\
S(x)^{b} \\
\text { of } \alpha \text { genes } c\end{array}$ & $\begin{array}{c}0 \\
37.0\end{array}$ & $\begin{array}{c}31.5 \\
32.0 \\
3\end{array}$ & $\begin{array}{c}42.4 \\
0 \\
2\end{array}$ & $\begin{array}{c}0 \\
32.1 \\
0 \\
3\end{array}$ & $\begin{array}{c}31.8 \\
0 \\
3\end{array}$ & $\begin{array}{c}31.4 \\
0 \\
3\end{array}$ & $\begin{array}{c}43.9 \\
0 \\
2\end{array}$ & $\begin{array}{l}0 \\
0 \\
2\end{array}$ \\
\hline
\end{tabular}

See pedigree in Fig. 3a.1.

b Quantitation by cation exchange HPLC; see text for details. $\alpha^{X}(x)=$ $x_{2}+x S x\left(=\alpha x_{2} x_{2} S\right) ; \beta_{2} S(x)=x S+x 5 x$.

C By gene mapping; see text for details.

TABLE 3a.2 Amino Acid Composition of the $\alpha T-4 A$ and $\alpha T-4 B$ Peptides of the $\alpha$ Chain of $\mathrm{Hb} \times(=\mathrm{Hb} \text { Chad })^{\mathrm{a}}$

\begin{tabular}{lll}
\hline $\begin{array}{l}\text { Amino Acid } \\
\text { (positions in } \alpha)\end{array}$ & $\begin{array}{c}\alpha T-4 A \\
(17-23)\end{array}$ & $\begin{array}{c}\alpha T-4 B \\
(24-31)\end{array}$ \\
\hline $\begin{array}{l}\text { Glutamic acid } \\
\text { Glycine } \\
\text { Histidine }\end{array}$ & $0(1)$ & $1.59(2)$ \\
$\begin{array}{l}\text { Arginine } \\
\text { Alanine } \\
\text { Valine } \\
\text { Tyrosine } \\
\text { Leucine } \\
\text { Lysine }\end{array}$ & $0.80(1)$ & $1.04(1)$ \\
\hline
\end{tabular}

a In mole/mole; numbers expected for the $\alpha^{A}$ chain are listed between parentheses. 


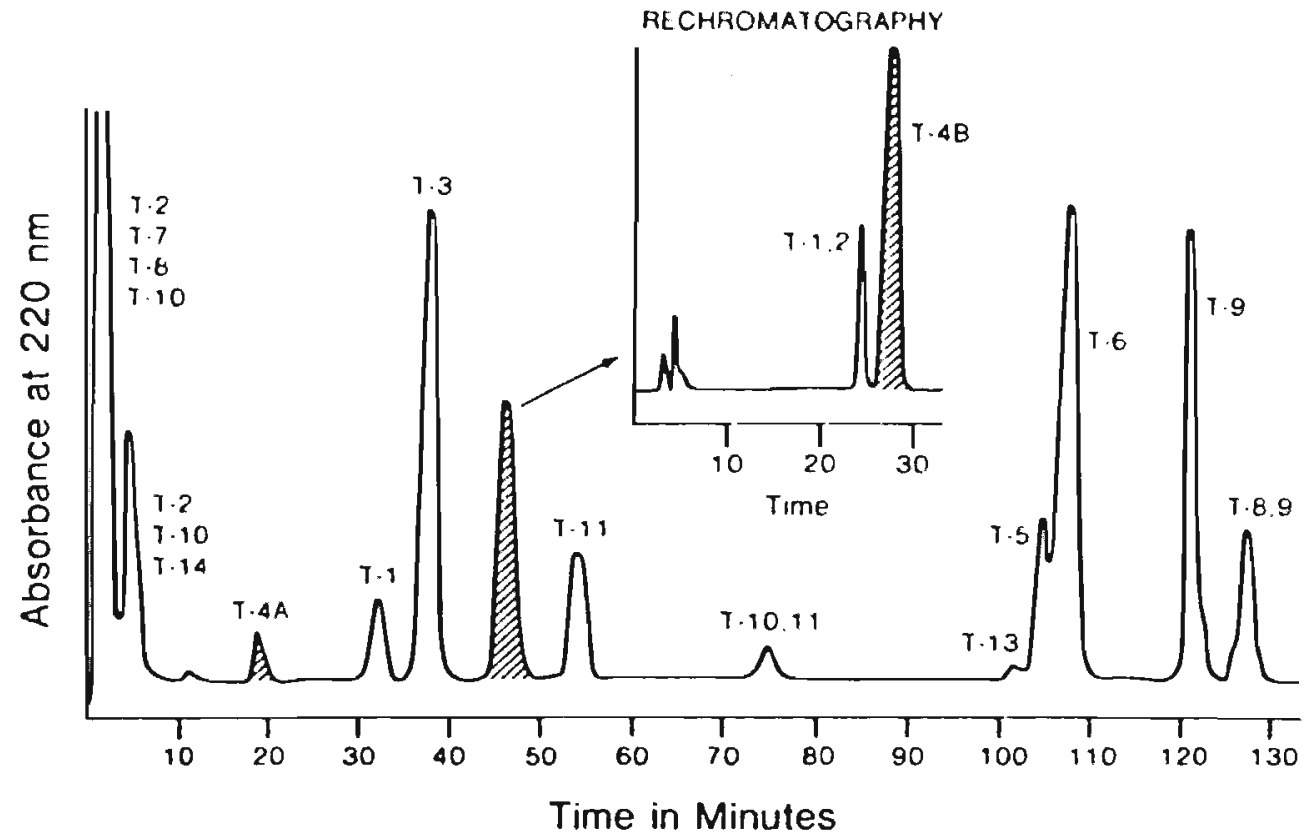

FI6. 3a.3 Separation of the soluble peptides of a tryptic digest of the $\alpha^{x}(=\alpha$-Chad $)$ chain by reversed phase HPLC using the method of Wilson et al (10). Insert: Rechromatography of a mixture of the $\alpha T-1,2$ and $\alpha T-4 \bar{B}$ peptides by reversed phase HPLC following the method described by Schroeder (11).

The results of the amplification-hybridization experiments are summarized in the bottom section of Fig. 3a.4. Data obtained for H.M. $(\alpha \alpha / \alpha \alpha)$ show amplification of both the $\alpha 2$ and $\alpha 1$ genes, while those for control $c_{2}$ and subject H.R. [ $-\alpha-\alpha ;$ homozygotes for the $\alpha$-thal-2 $(-3.7 \mathrm{~kb})$ anomaly] indicate amplification of the $\alpha 1-g l o b i n$ gene only [or of the $\alpha 221$ hybrid gene resulting from the $\alpha-$ thal-2 $(-3.7 \mathrm{~kb})$ deletion]. DNA from five members hybridized to the mutant probe; the mutation was present on the $\alpha 1$-globin gene (or on the $\alpha 2 \alpha$ hybrid gene of the $\alpha$-thal-2 chromosome) and not on the $\alpha 2$-globin gene. Two of the five samples (from B.R. and D.0) showed no amplification of the $\alpha 2$ gene (both subjects are $\alpha$-thal-2 homozygotes), while for the three remaining samples, a definite amplification of the $\alpha 2$ gene was detected with the normal probe (T.M., Re.R., and R.R.; all three are $\alpha$-thal-2 heterozygotes).

\section{DISCUSSION}

Data from the structural analyses reported here identify the variant as Hb Chad with a Gluxlys substitution at position 23 of the $\alpha$ chain. This is the fifth report dealing with this Hb variant; it is impossible to speculate if this abnormality is of Chinese, Japanese, or Black origin, or if it is the result of a new mutation in this population in South America. The 

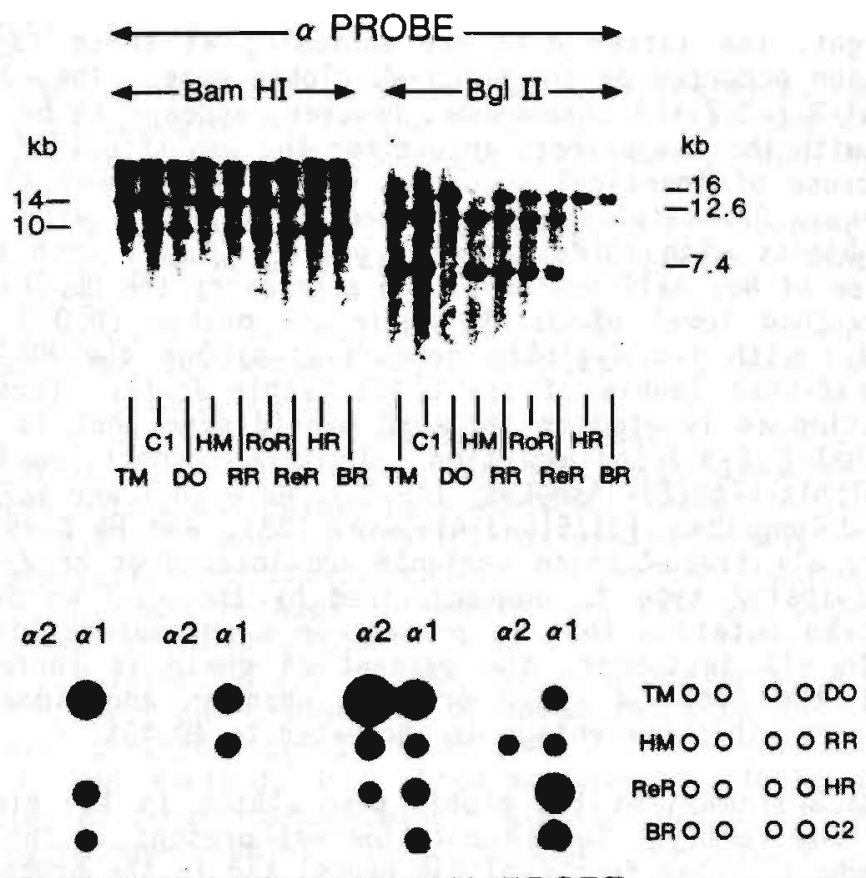

\section{MUTANT PROBE NORMAL PROBE}

$$
\begin{aligned}
& \text { T.M. }=-\alpha^{X / \alpha \alpha} \\
& \text { D.O. }=-\alpha^{x} /-\alpha \\
& H . M .=\alpha \alpha / \alpha \alpha \\
& \text { R.R. }=-a^{\mathrm{X} / a a} \\
& \operatorname{Re} \cdot R_{x}=-\alpha^{x / a \alpha} \\
& H \cdot R_{1}=-a l-a \\
& \text { B.R. }=-\alpha^{x} /-\alpha \\
& \mathrm{C} 2=-\alpha /-\alpha \text { (control) } \\
& \mathrm{C1}=\alpha a / a \alpha \text { (control) }
\end{aligned}
$$

FIG. 3a.4 $\alpha$-Globin gene mapping analyses for eight members of Family $M$. Top: Identification of the $3,7 \mathrm{~kb}$ deletion $(\alpha-$ thal-2) in Bam HI and $\mathrm{Bgl}$ II digests using the $32 \mathrm{p}$-labelled $\alpha$ probe for the detection of the normal and abnormal bands. Bottom: Dot-blot analyses of amplified DNA with the normal and mutant probes allowing the detection of the $\alpha$-Chad mutation. Amplification was with

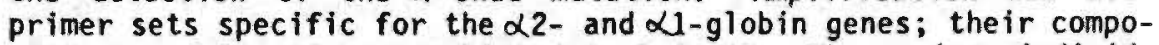
sitions and locations are listed in Ref. 18. The various individuals, identified by their initials, are shown in the pedigree of Fig. 3a.1.

Nomal Probe: $5^{\prime}$ CAC GGT GEC $\overline{6}$ |AG TAT 66T $63^{\prime}$ Mutant Probe: $5^{\prime}$ CAC GGT GGC A AG TAT GGT $63^{\prime}$ $\begin{array}{lllllllllll} & 20 & 21 & 22 & 23 & 24 & 25\end{array}$

Surinam family is distinct from the previously reported families because: a) $\mathrm{Hb}$ Chad occurred in one member together with $\mathrm{Hb} S$, resulting in the formation of the hybrid $\mathrm{Hb} S$-Chad or $\alpha_{2} \mathrm{Chad}_{3} \mathrm{~S}$, and b) the $\mathrm{Hb}$ Chad occurred on a $-\alpha(-3.7 \mathrm{~kb})$ thalassaemic chromosome. Data supporting this conclusion come from gene mapping experiments (Fig. 3a.4; top) and from dot-blot analyses after amplification of the $\alpha 2$ - and $\alpha 1-g$ lobin genes (Fig. 3a.4; bottom). 
At first sight, the latter data are confusing as these suggest that the $\alpha$-Chad mutation occurred on the minor $\alpha 1$-globin gene. The $\alpha 21$ hybrid gene of the $\alpha$-thal-2 (-3.7 kb) chromosome, however, appears to be amplified perfectly well with the two primers in use for the amplification of the $\alpha 1-g l 0-$ bin gene because of identical sequences of its $3^{\prime}$ scgment with that of the $\alpha 1$-globin gene. Quantitative $H b$ data are in agreement with the above conclusions; subjects with three $\alpha$-globin genes $(\alpha / \alpha \alpha)$, such as the propositus and three of her half-brothers, who also carry the Hb Chad abnormality, average an $\alpha$-Chad level of $31.7 \%$, while the mother (D.0.) and the halfbrother (B.R.) with two $\alpha$-globin genes $(\alpha-\alpha)$ and the $H b$ Chad heterozygosity, have $\alpha$-Chad levels of about 43\% (Table 3a.1). Thus, the $\alpha 23(B 4)$ Glysys mutation is located on the $\alpha 2 \beta 1$ hybrid gene that is characteristic for the $\alpha$-thal-2 $(-3.7 \mathrm{~kb})$ deletion. In this respect, $H b$ chad resembles Hb G-Philadelphia [Q68(E17)Asn 7 Lys] $(19,20), H b$ Q-Thailand [ 274 (EF3)AspłHis] $(21,22)$, Hb J-Tongariki $[\alpha 115(\mathrm{GH} 3) \mathrm{Ala} \rightarrow \mathrm{Asp}](23)$, and Hb Duan $[\alpha 75(\mathrm{EF} 4) \mathrm{Asp} \rightarrow$ Ala] $(24,25)$; all five $\alpha$ chain variants are located on an $\alpha$-thal-2 chromosome. The $\alpha$-thal-2 type is characterized by the $-3.7 \mathrm{~kb}$ deletion except for the $\mathrm{Hb}$ Duan mutation that is present on a chromosome with the $-4.2 \mathrm{~kb}$ deletion. In all instances, the percent $\alpha^{X}$ chain is increased to about one-third of the total $\alpha$ chain present; when an additional $\alpha-$ thal-2 is located in trans, this percentage is increased to $40-45 \%$.

Table 3a.3 summarizes the globin gene status in the eight members of this interesting family. The $\beta S$ mutation was present in the father of the propositus (who also had four $\alpha$-globin genes) and in the propositus herself. The $\alpha$-chad mutation was found on an $\alpha$-thal-2 homozygosity and for an $\alpha$-thal-2 heterozygosity (including the propositus). One half-brother of the propositus had an $\alpha$-tha1-2 homozygosity without the $\alpha$-Chad mutation.

TABLE 3a.3 Globin Gene Status of the Eight Members of Family $M$

\begin{tabular}{|c|c|c|c|}
\hline Subject $(s)^{\mathbf{a}}$ & Genes & ; & Genes \\
\hline H.M. & $\alpha \alpha / \alpha \alpha$ & ; & $\beta^{A / \beta} S$ \\
\hline D.0.;B.R. & $-\alpha^{x}(-3.7) /-\alpha(-3.7)$ & ; & \\
\hline H.R. & $-\alpha(-3.7) /-\alpha(-3.7)$ & ; & \\
\hline R.R.; Ro.R.; Re.R. & $-\alpha^{x}(--3.7) / \alpha \alpha$ & ; & $\beta^{A} / \beta^{A}$ \\
\hline T.M. & $-\alpha^{x}(-3.7) / \alpha \alpha$ & ; & $\beta^{A} / \beta^{S}$ \\
\hline
\end{tabular}

a See pedigree of Fig. 3a.1.

\section{ACKNOHLEDGEMENTS}

This research was supported in part by the United States Public Health Service Research Grants HLB-41544 and HLB-05168. This is contribution 1175 from the Department of Cell and Molecular Biology at the Medical College of Georgia in Augusta, Georgia. 
1. Boyer, S.H., Crosby, E.F., Fuller, G.F., Ulernurm, L., and Buck, A.A.: A survey of hemoglobins in the Republic of Chad and characterization of Hemoglobin Chad: $\alpha 2236 l u>d y s$ 32. Am. J. Hum. Genet., 20:570, 1968.

2. Blackwell, R.Q., Heng, M-I., and Huang, J.T.: Haemoglobin Chad $\alpha 23$ Glu leads to Lys in a Chinese family in Taiwan. Trop. Geogr. Med., $25: 393,1973$.

3. Sun, J., Fang, S. Wu, Q.,Wei, T., Chen, Li., Chen, P., and Chen, Lu.: Hb Chad $\left[23\left(B_{4}\right) G\left[u_{-} y_{y s}\right]\right.$ and its structural anaiysis. Acta Genet. Sin., 10:321, 1983.

4. Harano, T., Harano, K., Shibata, S., Ueda, S., Mori, H., Imai, K., and Yoshida, T.: Hemoglobin Chad [ 223 (B4) Glustys] discovered in a Japanese with questionable polycythemia. Hemoglobin, 7:581, 1983.

5. Righetti, P.G.: Practical application of isoelectricfocusing in hemoglobin separation and identification, in The Hemoglobinopathies, edited by T.K.J. Huisman, Methods in Hematology, Vol. 15, page 47, Churchill Livingstone, Edinburgh, 1986.

6. Ou, C.N., Buffone, G.J., Reimer, G.L., and Alpert, A.J.: High-performance liquid chromatography of human hemoglobins on a new cation exchanger. J. Chromatogr., 266:197, 1983.

7. Bisse, E. and Wieland, H.: High-performance liquid chromatographic separation of human haemoglobins - Simultaneous quantitation of foetal and glycated haemoglobins. J. Chromatogr., 434:95, 1988.

8. Schroeder, W.A. and Huisman, T.H.J.: The Chromatography of Hemoglobin, Clinical and Biochemical Analysis, Vol. 9, Marcel Dekker, Inc., New York, 1980.

9. Clegg, J.B., Naughton, M.A., and Weathera11, D.J.: Abnormal human haemoglobins. Separation and characterization of the $\alpha$ and $\beta$ chains by chromotography, and the determination of two new variants, Hb-Chesapeake and Hb-J (Bangkok). J. Mol. Biol., 19:91, 1966.

10. Wilson, J.B., Lam, H., Pravatmuang, P., and Huisman, T.H.J.: Separation of tryptic peptides of normal and abnormal $\alpha, \beta, \gamma$, and $\delta$ hemoglobin chains by high-performance liquid chromatography. J. Chromatogr., 179:271, 1979.

11. Schroeder, W.A.: High performance liquid chromatography used in structural analyses of hemoglobin variants, in The Hemoglobinopathies, Methods in Hematology Series, edited by T.H.J. Huisman, Vol. 15, page 142, Churchill Livingstone, Edinburgh, 1986.

12. Poncz, M., Solowiejczyk, D.. Harpel, B., Mory, Y., Schwartz, E., and Surrey, S.: Construction of human gene libraries from small amounts of peripheral blood: Analysis of $\beta-l i k e$ globin genes. Hemoglobin, $6: 27,1982$.

13. Felice, A.E., Cleek, M.P., Mckie, K., McKie, Y.C., and Huisman, T.H.J.: The rare $\alpha$-thalassemia- 1 of Blacks is a $3 \alpha$-thalassemia-1 associated with a deletion of all $\alpha$ - and 3 -globin genes. Blood, 63:1253, 1984.

14. Felice, A.E., Cleek, M.P., Marino, E.M., McKie, K., McKie, V.C., Chang, B.K., and Huisman, T.H.J.: Different $z$ globin gene deletions among Black Americans. Hum. Genet., 73:221, 1986.

15. Saiki, R.K., Bugawan, T.L., Horn, G.T., Mullis, K.B., and Erlich, H.A.: Analysis of enzymatically amplified $\beta$-globin and $H L A$ DQ $\alpha$ DNA with allele-specific oligonucleotide probes. Nature, 324:163, 1986. 
16. Saiki, R.K., Gelfand, D.H., Stoffel, S., Scharf, S.J., Higuchi, R,, Horn, G.T., Mullis, K.B., and Erlich, H.A.: Primer directed enzmatic amplification of DNA with a thermostable DNA polymcrase. Science, $239: 487,1988$.

17. Jogessar, V.B., Westermeyer, K., Kebber, B.B., Wilson, J.B., GonzalezRedondo, J.M., Kutlar, A., and Huisman, T.H.J.: Hb Natal or $\alpha_{2}$ (minus Tyr-Arg/B2, a high oxygen affinity $\alpha$ chain variant with a deleted carboxy-terminus resulting from a TAC $\rightarrow$ TAA (Tyr $\rightarrow$ terminating codon) mutation in codon $\alpha 140$. Biochim. Biophys. Acta, 951:36, 1988 .

18. Zhao, J., Gonzalez-Redondo, J.M., Altay, C., Gurgey, A., George, E., Efremov, G.D., Wong, S.C., and Huisman, T.H.J.: Deletional and nondeletional $\alpha$-thalassemia in Hb $H$ disease. NATO ASI Series, in press.

19. Milner, P.F. and Huisman, T.H.J.: Studies on the proportion and synthesis of Haemoglobin G Philadelphia in red cells of heterozygotes, a homozygote, and a heterozygote for both Haemoglobin $G$ and $\alpha$ thalassaemia. Br. J. Haematol., 34:207, 1976.

20. Felice, A.E., Mayson, S.M., Webber, B.B., Miller, A., Gravely, M.E., and Huisman, T.H.J.: Hb S, Hb G-Philadelphia and $\alpha$-thalassemia-2 in a Black family. Pediatr. Res., 14:266, 1980.

21. Vella, F., Wells, R.H.C., Ager, J.A.M., and Lehmann, H.: A haemoglobinopathy involving Hemoglobin $H$ and a new (Q) haemogloglobin. Br. Med. J., j:652, 1958.

22. Beris, P., Huber, P., Miescher, P.A., Wilson, J.B., Kutlar, A., Chen, S.S., and Huisman, T.H.J.: Hb Q-Thailand-Hb $H$ disease in a Chinese living in Geneva, Switzerland: Characterization of the variant and identification of the two $\alpha$-thalassemic chromosomes. Am. J. Hematol., $24: 395,1987$.

23. Gajdusek, D.C., Guiart, J., Kirk, R.L., Carrell, R.W., Irvine, D., Kynoch, P.A.M., and Lehmann, H.: Haemoglobin J-Tongariki $(\alpha-115$ alaninesaspartic acid): The first new haemoglobin variant found in a Pacific (Melanesian) population. J. Med. Genet., 4:1, 1967.

24. Liang, C-C., Chen, S-S., Jia, P-C., Wang, L-T., LUo, H-Y. , Liu, G-Y., Liang, S., Lung, G-F., Yu, C-M., Zhuang, L-Z., Liang, B-L., and Tang, Z-N.: Hemoglobin Duan, $\alpha 75(E F 4) A s \beta>A l a$, a new variant found in China. Hemoglobin, 5:481, 1981 .

25. Liang, S., Tang, Z., Su, C., Lung, Q., Liang, R., Fei, Y.J., Kutlar, F., Wilson, J.B., Webber, B.B., Hu, H., and Huisman, T.H.J.: Hb Duan

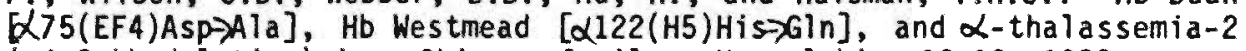
$(-4.2 \mathrm{~kb}$ deletion) in a Chinese family. Hemoglobin, $12: 13,1988$. 
CHAPTER 3b

THE $\beta^{S}$ GENE IN THE SURINAM POPULATION:

HAEMATOLOGICAL AND GENETIC OBSERVATIONS 
THE 3 S GLNE IN THE SURINAM POPULATION:

HAEMATOLOGICAL AND GENETIC OBSERVATIONS

\section{ABSTRACT}

Haematological and genetic data have been collected for $12 \mathrm{SS}$, one $S C$, and four S-B-thal patients and their relatives. Haplotyping, using $32 p$ labelled oligonucleotide specific probes, identified haplotypes $\$ 19$ and \#20 as the major types among the Surinam population. Both haplotypes have been reported to originate from West and Central Africa. These results suggest that the ${ }^{S}$ gene among Surinamese was introduced by the slave trade, common in the 19 th century in that part of the world. Haematological data showed that AS individuals are clinically normal, while the SS patients have a severe anaemia with a variety of complications, comparable to those observed for SS patients from Africa and the United States. The AS individuals did not have significantly increased levels of circulating foetal $\mathrm{Hb}$ ( $H b F<1 \%)$, while the foetal $\mathrm{Hb}$ level in the $12 \mathrm{SS}$ patients averaged about $10 \%$.

\section{INTRODUCTION}

The occurrence of the $\beta^{S}$ gene in the Surinam population was first described in 1938 by Wolf (1) who made sickle cell preparations of the blood from people living in two Bush Negro villages. Data from several other studies have been reported (2-7) and in some, the frequencies of $\mathrm{Hb} S$ among the different ethnic groups were determined. Frequencies up to 0.22 were found among the different Bush Negro tribes, while the Creole group showed a frequency of about 0.10 , which is comparable to that found in American Blacks (8). Some isolated cases of $\mathrm{Hb} S$ heterozygosities have been observed among the native Indian and Hindustani groups. The presence of $\mathrm{Hb} S$ among the native Indians was ascribed to admixture with Creoles (9), and in one case in which the $\beta^{S}$ gene originated from a Hindustani male, haplotyping of the gene was not performed (10).

The clinical expression of sickle cell anaemia is severe in the Surinam population. Two factors that are considered to modify the disease are the presence of an $\alpha$-thal and an increased production of $H b F(11)$. The variation in the level of $H b S$ in SS patients is related to the different genetic backgrounds on which the $3 S$ gene occurs. There are at least five different chromosomes bearing the $\$ S$ mutation (12-18). These chromosomes have been characterized by specific haplotypes, and were identified as haplotype 19 (Benin), \#20 [Bantu or CAR (Central African Repub1ic)], 3 (Senegal), \#31 (Saudi Arabia-India), and $\$ 17$ (Cameroon or A ${ }^{\top}$ ). Homozygotes for haplotypes $\# 19$ or \#20 have Hb F levels of about $10 \%$, while SS patients with haplotypes $\$ 3$ or 31 may have Hb F levels of 20 to $35 \%(19,20)$. Haplotype 31 has been discovered in patients from India and the eastern part of Saudi Arabia; these patients have a considerably milder disease. 
Haplotypes 19,120 , and 3 are the major haplotypes present in Black SS patients from Jamaica, West and Central Africa, and the Southeastern United States $(21,22)$. In the investigation performed by Aluoch et al (23), 16 Surinamese SS patients living in The Netherlands were studied, and their haplotypes were compared to those of Eti-Turk SS patients. The major haplotype among the 16 Surinamese SS patients were also $\$ 19$, 20 , and 3 . Here we describe the use of haplotype-specific probes for the identification of particular haplotypes in $\mathrm{SS}$ patients and $\mathrm{Hb} S$ heterozygotes living in Surinam. A comparison will be made between the haematological data for the SS patients with the different haplotypes present in the Surinam population.

\section{MATERIALS AND METHODS}

3.1 Patients. Two hundred and one newborn babies were screened by IEF for the possible presence of haemoglobinopathies. Eleven individuals had the FAS phenotype and were included in this study. An additional 5l individuals (12 with SS and 39 with AS) from 35 unrelated families were selected with the help of local physicians. Data for relatives with a $\mathrm{Hb} S$ trait were collected so that accurate haplotypes for the SS patients could be determined. The newborn babies were included in an attempt to determine the incidence of the $\beta S$ gene among different ethnic groups. All individuals with the $3 S$ gene were enrolled in a larger screening project, of which the haplotype data have been reported elsewhere (24).

3.2 Methods. Methodology used in this study has been described in Chapter 2. Fig. 3b.1 shows the positions of the sequence differences used to construct the specific oligonucleotide probes for the different haplotypes; this information was obtained from Refs. 25-29.

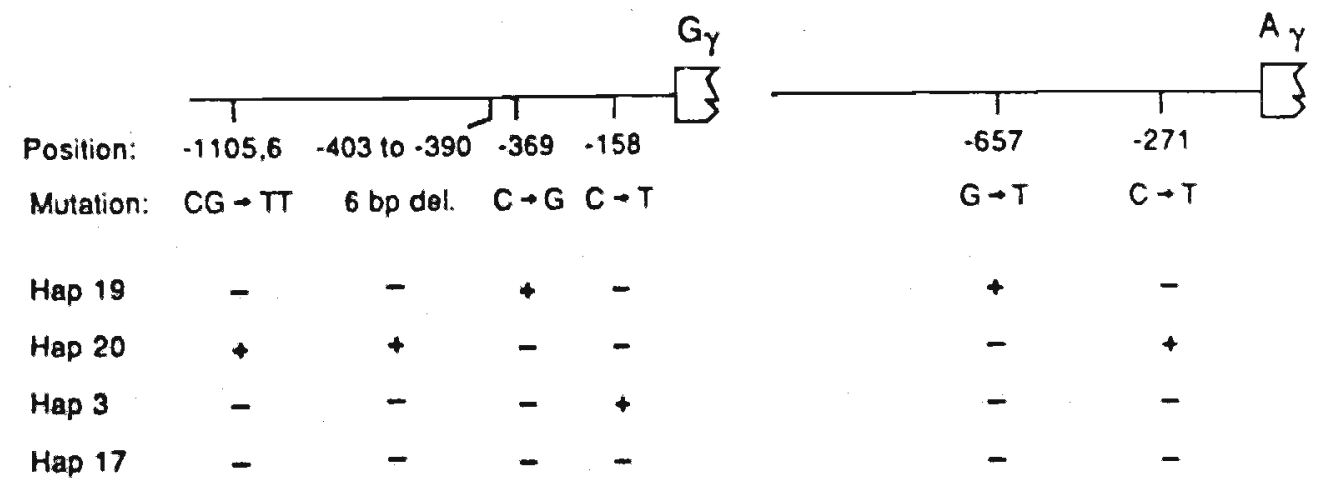

FIG. 3b.1 Haplotype-specific sequence differences in the $5^{\prime}$ flanking region of the $G_{\gamma}$ - and $A_{\gamma-g l o b i n}$ genes among $\beta$ shromosomes; + or - indicates the presence or absence of a particular mutant site. 
4. RESULTS

4.1 The Haplotypes. The results obtained for 62 individuals with $74 \mathrm{BS}^{\mathrm{S}}$ chromosomes are sumarized in Table $3 \mathrm{~b} .1$; the same table contains data for other populations which is also included in another study (24). Characterization of the $\beta^{S}$ chromosome with haplotype 17 was based upon the presence of the AY chain detected by reversed phase HPLC. The low level of $\mathrm{Hb} F$ in most AS subjects made it impossible to exclude haplotype \#17 in these cases. The most common type was haplotype 19, that occurred on 41 of the 74 chromosomes. Haplotype 20 was observed 23 times, haplotypes \#3 or \$31 twice, and haplotype \#17 only once; eight chromosomes were uncharacterized. Identification of haplotype $\| 19$ chromosomes was based on the presence of two specific mutations, namely a $G \rightarrow T$ mutation at position -657 relative to the Cap site of the $A_{\gamma}$-globin gene, and a $G \rightarrow G$ mutation at position $-3695^{\prime}$ to the G-globin gene. Haplotype \#20 was determined by the presence of three specific mutations, namely $G \rightarrow T$ at position 271 $5^{\prime}$ to $\mathrm{Ar}, \mathrm{CG} \rightarrow \pi$ at positions -1105 and -1106 to $\mathrm{Gr}$, and a $6 \mathrm{bp}$ deletion between positions -403 to $-3905^{\prime}$ to $G_{\gamma}$ (Fig. 3b.1). Haplotypes 3 and \#31 had $C \rightarrow T$ mutations at position -158 .

TABLE 3b.1 Distribution of Particular Haplotypes Among Different Populations

\begin{tabular}{|c|c|c|c|c|c|c|}
\hline Country & $\begin{array}{c}\text { No. of } \beta S \\
\text { Chroms. Tested }\end{array}$ & $\$ 19$ & $\$ 20$ & $\begin{array}{l}\text { Haplotypes } \\
3 \text { or } 31\end{array}$ & $\# 17$ & Rare \\
\hline Southeastern USA & 366 & 205 & 71 & 58 & 13 & 19 \\
\hline Kenya & 55 & 1 & 52 & - & - & 2 \\
\hline Turkey & 179 & 174 & - & - & - & 5 \\
\hline Syria & 13 & 13 & - & - & - & - \\
\hline Tunisia & 115 & 109 & - & - & - & 6 \\
\hline Italy & 70 & 70 & $=$ & - & - & - \\
\hline Surinam & 74 & 41 & 23 & 2 & - & 8 \\
\hline South Africa & 5 & - & - & 5 & - & - \\
\hline Canada & 14 & 10 & - & 4 & - & - \\
\hline India & 105 & - & - & 94 & - & 11 \\
\hline Greece & 14 & 13 & - & 1 & - & - \\
\hline West Nigeria & 104 & 97 & - & - & 3 & 4 \\
\hline
\end{tabular}

Our data also showed that some of the specific mutations occurred on a $\mathrm{P}^{\mathrm{A}}$ chromosome. An example is the AS individual S-502, who had mutations specific for two different haplotypes on the same chromosome. This information is provided in Fig. 3b.2. The daughter of subject $\mathrm{S}-502$ had severe SS disease; her two $\mathrm{F}^{5}$ chromosomes had the $\$ 20$ haplotype. This information facilitated the identification of the unusual haplotype in her mother $(\mathrm{S}-502)$. 


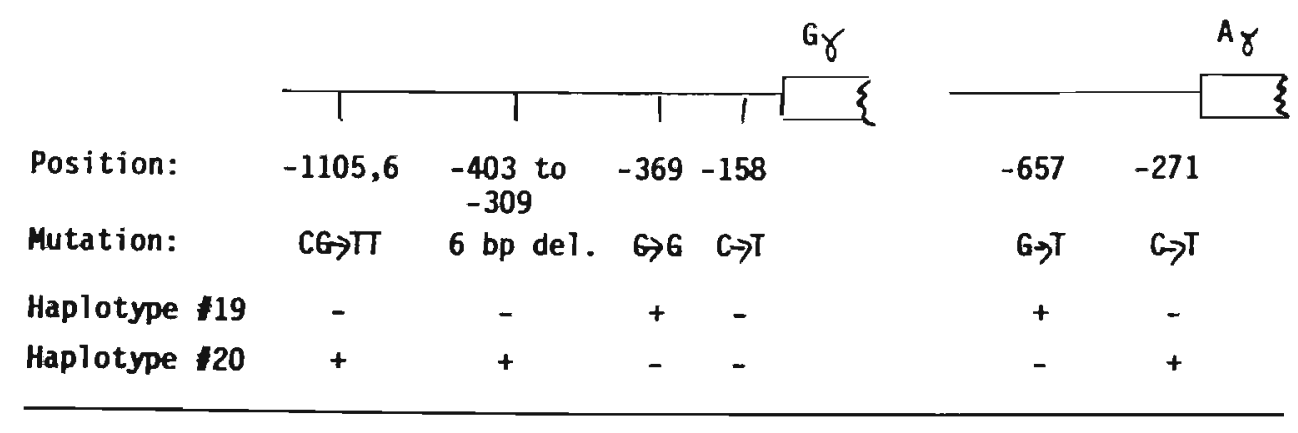

\section{S-502}

Haplotype 120 $\left(\beta^{S}\right)$
$+\left(\beta^{A}\right)$

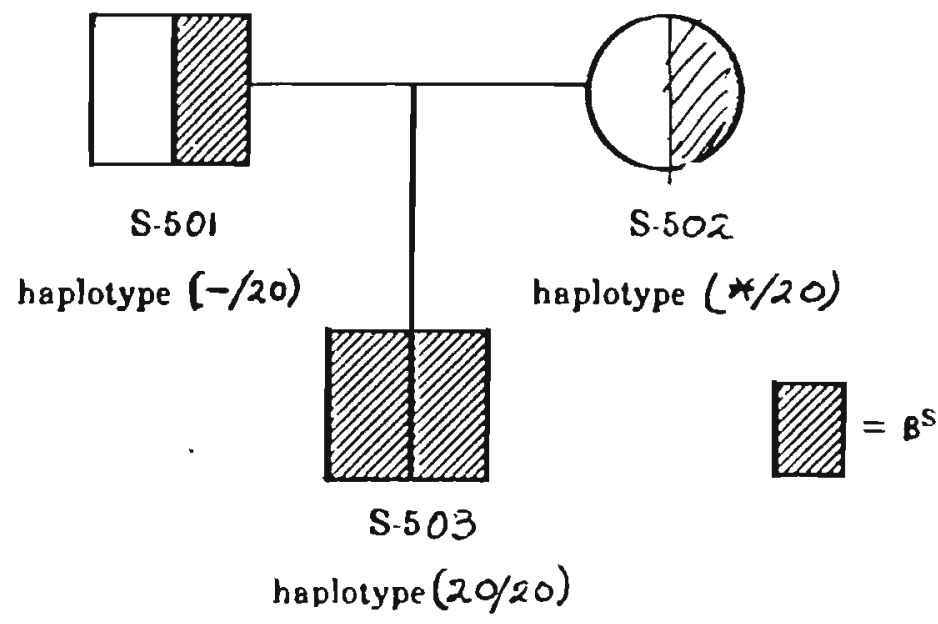

FI6. 3b.2 35 Haplotyping for family members of a homozygous haplotype \#20 subject. Top: The haplotype-specific mutations for the $\beta \bar{S}$ chromosome of the propositus (mother S-502) and her $3 A$ chromosome. Bottom: The pedigree of this family indicating the pattern of inheritance of the genes. The asterisk $\left(^{*}\right)$ denotes an atypical combination.

Another interesting observation was made in SS patient S-532 (Fig. 3b.3). This 7-year-old boy carried two 35 chromosomes, both with haplotype 19, except that one chromosome was also characterized by the presence of

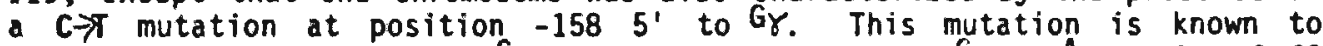
increase the production of $G_{\gamma}$ chains, and indeed, a $G_{\gamma}$ to $A_{\gamma}$ ratio of 60 
to 40 was found in patient $5-502$, while the $H b F$ of all other SS patients had a ratio of 40 to 60 . Further testing of the parents indicated that this special $\hat{\beta} S$ chromosome was inherited from the father $(5-534)$. Of the several hundreds of $\beta^{S}$ chromosomes with haplotype 19 tested so far, only the $\beta S$ chromosome of this surinam family is know to be characterized by haplotype $\$ 19$ and by the simultaneous presence of the $G \rightarrow T$ mutation at position -158 .

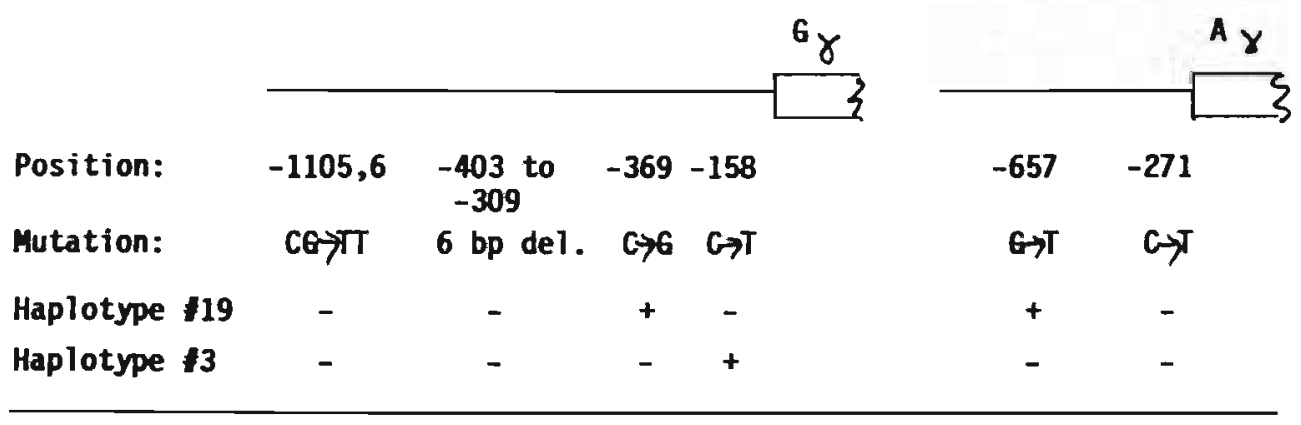

S-532

Haplotype 19

( $\left.\beta^{S}\right)$

Haplotype $\$ 19$

(BS) $(x=1+)$
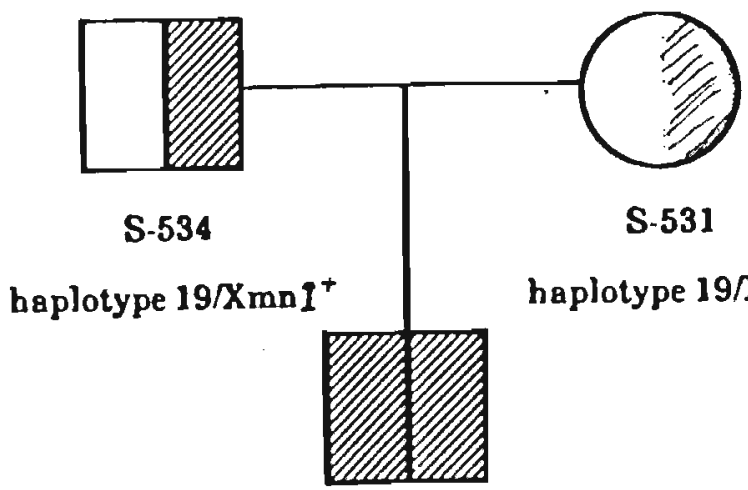

haplotype $19 / \mathrm{XmnI}^{-}$

S.532

haplotype $19 / 19$

$(\mathrm{X} m \mathrm{I}+)(\mathrm{Xmn} \mathrm{I}-)$

FI6. 3b.3 Top: Haplotype analyses for a family with atypical haplotype patterns. Bottom: Pedigree of this family showing the atypical combination of haplotype 19 with an $X_{m n} I+$ site on the same chromosome. 
4.2 Clinical Expression of the SS Discase. Hacmatological data and the $\mathrm{Hb} F$ levels in the patients homozygous for the different haplotypes are listed in Table 3b.2. Hb levels in patients $S-444$ and $S-471$ were low due to blood transfusions given prior to collection of the samples. The exact age of patient S-527 was not known but estimated at 45 years. This male individual is a fisherman and performs intensive physical labour on a daily basis. Unfortunately, we were unable to perform a detailed family study, which precluded the exclusion of a possible Hb S-HPFH combination. The high level of $\mathrm{Hb} \mathrm{F}(22 \%)$ is likely the main reason for his well-being, as such levels probably interfere with the polymerization of deoxy $\mathrm{Hb} S$ molecules. It is worth noting that the haematological data for patient S-532 (see (Table 3b.2) are comparable to those of the other patients.

TABLE 3b.2 Haematological Data for 12 SS Patients From Surinam

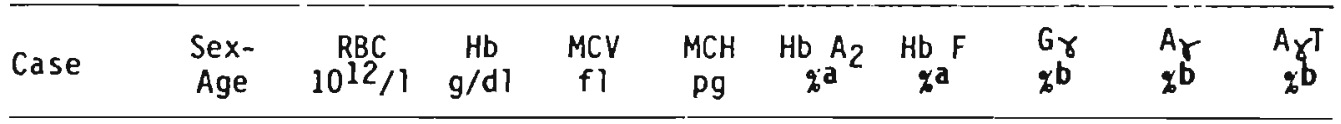

Haplotypes $19 / 19$

$\begin{array}{lllrrrrrrrr}\text { S-261 } & \text { F-18 } & 3.02 & 8.3 & 89 & 27.4 & - & 10.2 & 42.0 & 58.0 & 0 \\ \text { S-444 } & \text { F-11 } & 3.3 & 8.9 & 97 & 26.6 & 3.8 & <1.0 & 40.0 & 60.0 & 0 \\ \text { S-471 } & \text { M- } 6 & 3.2 & 5.7 & 74 & 17.6 & - & 1.3 & 36.0 & 64.0 & 0 \\ \text { S-519 } & \text { F-10 } & 1.73 & 4.9 & 107 & 28.3 & 2.5 & 10.2 & 40.0 & 60.0 & 0 \\ \text { S-527 } & \text { M-45(?) } & 3.5 & 11.1 & 103 & 31.6 & 3.3 & 21.9 & 48.0 & 52.0 & 0 \\ \text { S-532C } & \text { M- 7 } & 2.17 & 6.8 & 104 & 31.3 & 2.7 & 10.0 & 60.0 & 40.0 & 0\end{array}$

Haplotypes $19 / 20$

$\begin{array}{llllrlllllll}\text { S-254 } & \text { F-18 } & 3.79 & 8.6 & 74 & 22.7 & - & 5.9 & 37.0 & 63.0 & 0 \\ \text { S-521 } & \text { F-16 } & 2.22 & 6.7 & 106 & 30.0 & 3.1 & 6.0 & 44.0 & 56.0 & 0\end{array}$

Haplotypes $20 / 20$

$\begin{array}{rrrrrrrrrrr}\text { S-503 } & \text { F-23 } & 1.48 & 4.8 & 105 & 27.7 & 3.6 & 7.8 & 37.0 & 63.0 & 0 \\ \text { S-516 } & \text { F- } 9 & 1.52 & 3.9 & 95 & 25.0 & 3.9 & 5.8 & 42.0 & 58.0 & 0 \\ \text { S-517 } & \text { M- } 6 & 2.58 & 6.4 & 93 & 24.8 & 3.8 & 3.5 & 37.0 & 63.0 & 0\end{array}$

Haplotypes $19 / 17$

$\begin{array}{lllllllllll}\text { S-447 } & \text { M- } 8 & 1.2 & 3.3 & 113 & 27.5 & 2.7 & 11.2 & 44.8 & 34.1 & 21.1\end{array}$
a By cation exchange HPLC.
b By reversed phase HPLC.
c See Fig. 3b.3 and text for further details.

All other patients with haplotypes 19/20, 20/20, and 19/17 had severe disease, low $\mathrm{Hb} F$ levels with a $G_{\gamma}$ value of about $40 \%$. The incidence of haplotype 11 was low as only one of the 12 SS patients was heterozygous for this variant. Haplotypes $\$ 3$ and \$31 were not found.

Analyses of the $\beta S$ haplotypes of the newborn babies with a Hb $S$ heterozygosity showed that haplotype 19 was the most common type (nine of 11 babies had this haplotype and two had haplotype 20 ). The limited number 
of AS newborns makes it impossible to determine the frequencies of these haplotypes.

\section{CONCLUSION}

Based upon population data provided by the Surinam government (Table $3 b .3$ ), it can be calculated that at least 15,000 Hb $S$ heterozygotes are living in Surinam. This estimate is based upon the $10 \%$ frequencies expected and observed among Creoles and Bush Negroes. These data also suggest that about 500 SS patients are living in Surinam at present. The high birth rate among the Bush Negro population and their urbanization makes it likely that this number is too low.

TABLE 3b.3 Composition of the Surinam Populationa

\begin{tabular}{lrrrr}
\hline Racial/Ethnic Background & 1950 & 1964 & 1971 & 1980 \\
\hline Creole & 74,918 & 114,961 & 119,009 & 123,285 \\
Hindustani & 63,770 & 112,633 & 142,917 & 118,983 \\
Indonesian & 35,949 & 48,463 & 57,688 & 58,004 \\
Chinese & 2,468 & 5,339 & 6,029 & 5,494 \\
European & 2,626 & 4,322 & 3,999 & 1,558 \\
Indian & 1,846 & 2,979 & 3,929 & 4,664 \\
Others & 1,703 & 2,986 & 6,077 & 2,274 \\
Unknown & 401 & 522 & - & 710 \\
"Bosneger in stamverb" & 19,180 & 27,698 & 35,835 & 33,915 \\
Native Indian & 1,700 & 4,308 & 4,121 & 6,353 \\
\hline TOTAL & 204,561 & 324,211 & 379,607 & 355,240 \\
\hline
\end{tabular}

a Based on census data.

Haplotype-specific probes are valuable tools in the determination of $\mathrm{B}^{5}$ haplotypes; all 12 SS patients could be characterized by this technique. Some of the $\beta A$ chromosomes in the Surinam population may have mutations that are considered to be specific for the $\$^{S}$ chromosomes.

Although the group of 12 SS patients and 11 AS newborn babies is small, the data obtained indicate that most, if not all, $\beta S$ chromosomes carry a haplotype that is associated with low levels of $H \mathrm{H} F$ and severe disease in the homozygote. Haplotypes 19 and $\$ 20$ indeed appear to occur together in nearly all tested subjects; data from several surveys conducted in other countries have indicated that such $\beta S$ chromosomes are invariably observed in SS patients who are severely affected by this disease, as evidenced by severe haemolysis and frequent crises. 


\section{REFERENCES}

1. Wolff, A.E.: Sicklemia and sickle cell anemia in Surinam. Acta Leiden, 14:288, 1939.

2. Gijzel, W.P., Adkin, S.D., and Oemrawsingh, I.: Abnormal hemoglobins in Surinam. I. Frequency among different ethnic groups. Sur. Med. Bull., 1978.

3. Collier, W.A. and de la Parra, D.A.: Contributions to geographical pathology of Suriman; blood groups of some American Indian settlements. Docum. Med. Geogr. Trop., 4:223, 1952.

4. Liachowitz, C., Elderkin, J., Guicherit, I., Brown, H.W., and Ranney, H.R.: Abnormal hemoglobins in the Negroes of Surinam. Am. J. Med., $24: 19,1958$.

5. Pik, C., Loos, J.A., Jonxis, J.H.P., and Prins, H.K.: Hereditary and acquired blood factors in the Negroid population of Surinam. II. The incidence of haemoglobin anomalies and the deficiency of glucose6-phosphate dehydrogenase. Trop. Geogr. Med., 17:61, 1965.

6. De Geus, A., Vergote, F.J., and Koopmanschap, M.: Eindrapport van het onderzoek naar het hemoglobine-gehalte bij Nederlandse en Surinaam/ Antilliaanse zuigelingen en hun moeders in de Bijlmermeer. Kon. Inst. Tropen., 1977 (eindrapport).

7. Jonxis, J.H.P.: Haemoglobinopathien in gezinnen van buitenlandse werknemers en andere migrantengropepen. Ned. Tijdschr. Geneeskd., 121: $949,1977$.

8. Huisman, T.H.J., Abraham, B.L., Harris, H.F., Gravely, M.E., Henson, J., Williams, D., Wilson, J.B., Miller, A., Mayson, S., Wrightstone, R.N., Moss, E., Joseph, B., Walker, L., Brisco, J., and Brisco, L.: Hemoglobinopathies observed in the population of the Southeastern United States (SE-USA). Hemoglobin, 4:373, 1980.

9. Geerdink, R.A., Okura, K., Li Fo Sjoe, E., Schillhorn-van Veen, J.M., and Bartstra, H.A.: Serum factors and red cell enzymes in Carib and Arowak Indians from Surinam. Trop. Geogr. Med, , 27:260, 1975.

10. Landman, H.: Haemoglobinopathies and pregnancy. Thes is, Groningen, 1988.

11. Higgs, D.R., Aldridge, B.E., and Lamb, J.N.: The interaction of $\alpha$-thalassemia and homozygous sickle-cell disease. N. Engl.J. Med., $306: 1441,1982$.

12. Pagnier, J., Mears, J.G., Dunda-Belkhodja, O., Schaefer-Rego, K.E., Beldjord, G. , Nagel, R.L., and Labie, D.: Evidence for the multicentric origin of the sickle cell hemoglobin gene in Africa. Proc. Natl. Acad. Sci. USA, 81:1771, 1984.

13. Kulozik, A.E., Wainscoat, J.S., Serjeant, G.R., Kar, B.C., Al-Awamy, B., Essan, G.J.F., Falusi, A.G., Haque, S.K., Hilali, A.M., Kate, S., Ranasinghe, W.A.E.P., and Weatherall, D.J.: Geographical survey of $\beta^{S}$ globin gene haplotypes: Evidence for an independent Asian origin of the sickle cell mutation. Am. J. Hum. Genet., 39:239, 1986.

14. Miller, B.A., Olivieri, N., Salameh, M., Ahmed, M., Antognetti, G., Huisman, T.H.J., Nathan, D.G., and Orkin, S.H.: Molecular analysis of the high-Hemoglobin F phenotype in Saudi Arabian sickle cell anemia. N. Eng1. J. Med., 316:244, 1987.

15. Lapoumeroulie, C., Dunda, 0., Trabuchet, G., Money-Lobe, M., Labie, D., Elion, J., and Krishnamoorthy, R.: A novel sickle gene of yet another origin in Africa: The Cameroon type, Blood, 74:63a (Suppl. 1), 1989. 
16. Nagel, R.L., Fabry, M.E., Pagnier, J., Zohoun, I., Wajcman, H., Baudin, V., and Labie, D.: Hematologically and genetically distinct forms of sickle cell anemia in Africa. The Senegal type and the Benin type. N. Engl. J. Med., 312:880, 1965.

17. Nagel, R.L., Rao, S.K., Dunda-Belkhodja, 0., Connolly, M.M., Fabry, M.E., Georges, A., Krishnamoorthy, R., and Labie, D.: The hematological characteristics of sickle cell anemia bearing the Bantu haplotype. The relationship between $G_{\gamma}$ and $\mathrm{Hb} F$ levels. Blood, 69:1026, 1987.

18. Ojwang, P.J., Ogada, T., Beris, P., Hattori, Y., Lanclos, K.D., Kutlar, A., Kutlar, F., and Huisman, T.H.J.: Haplotypes and $\alpha$ globin gene analyses in sickle cell anaemia patients from Kenya. Br. J. Haematol., $65: 211,1987$.

19. Kutlar, A., Hattori, Y., Bakioglu, I., Kutlar, F., Kamel, K., and Huisman, T.H.J.: Hematological ohservations on Arabian SS patients with a homozygosity or heterozygosity for a $\beta^{S}$ chromosome with haplotype $\$ 1$. Hemoglobin, 9:545, 1985.

20. Bakioglu, I., Hattori, Y., Kutlar, A., Mathew, C., and Huisman, T.H.J.: Five adults with mild sickle cell anemia share a $Z^{S}$ chromosome with the same haplotype. Am. J. Hematol., 20:297, 1985.

21. Antonarakis, S.E., Boehm, C.D., Serjeant, G.R., Theisen, C.E., Dover, G.W., and Kazazian, H.H., Jr.: Origin of the $3 S^{2}$ globin gene in Blacks; the contribution of recurrent mutation or gene conversion or both. Proc. Natl. Acad. Sci. USA, 81:835, 1984.

22. Hattori, Y., Kutlar, F., Kutlar, A., McKie, V.C., and Huisman, T.H.J.: Haplotypes of $\beta S$ chromosomes among patients with sickle cell anemia from Georgia. Hemoglobin, 10:623, 1986.

23. Aluoch, J.R., Kilins, Y., Aksoy, M., Yuregir, G.T., Bakioglu, I, Kutlar, A., Kutlar, F., and Huisman, T.H.J.: Sickle cell anaemia among Eti-Turks: Haematological, clinical and genetic observations. $\mathrm{Br}$. J. Haematol., 64:45, 1986.

24. Oner, C. Personal communication.

25. Miller, B.A., Salameh, M., Ahmed, M., Olivieri, N., Antognetti, G., Orkin, S., Huisman, T.H.J., and Nathan, D.G.: Analys is of Hemoglobin F production in Saudi Arabian families with sickle cell anemia. Blood, $70: 716,1987$.

26. Bouhassira, E.E., Lachman, H., Krishnamoorthy, R., Labie, D., and Nagel, R.L.: A gene conversion located $5^{\prime}$ to the $A_{r}$ gene in linkage disequilibrium with the Bantu haplotype in sickle cell anemia. J. Clin. Invest., 83:2070, 1989.

27. Month, S.R., Wood, R.W., Trifillis, P.T., Orchowski, P.J., Sharon, B., Ballas, S.K., Surrey, S., and Schwartz, E.: Analysis of 5 ' flanking regions of the gama globin genes from major African haplotype backgrounds associated with sickle cell disease. J. Clin. Invest., $85: 364,1990$.

28. Lanclos, K.D., Oner, C., Dimovski, A.J., Gu, Y-C., and Huisman, T.H.J.: Sequence variations in the $5^{\prime}$ flanking and IVS-II regions of the Gyand $A \gamma-g l o b i n$ genes of $\beta S$ chromosomes with five different haplotypes. Blood, 77:2488, 1991 .

29. Dimovski, A.J., Oner, C., Agarwal, S., Gu, Y-C., Gu, L-H., Kutlar, F., Lanclos, K.D., and Huisman, T.H.J.: Certain mutations observed in the $5^{\prime}$ sequences of the $G$ - and $A \gamma-g l o b i n$ genes of $\mathcal{S}^{S}$ chromosomes are specific for chromosomes with major haplotypes. Acta Haematol., $85: 79,1991$. 


\section{0}


CHAPTER 4

THALASSAENIAS IN THE

SURINAM POPULAT I.ON 
102 
CHAPTER 4a

MOLECULAR CHARACTERIZATION OF \$-THALASSAEMIA AMONG THE SURINAMESE 
MOLECULAR CHARACIERIZATION OF

B-THALASSAEMIA AMONg SURINAMESE

\section{ABSTRACT}

Twenty Surinamese fanilies with $\beta$-thal were screened for particular mutations using $32 p-1$ abelled ol igonucleotide probes, sequence analysis, and gene mapping. Thirteen different mutations were detected. The IVS-I-5 $(G)$ C) was the most frequently observed, being present in six of the 20 families, followed by the frameshift at codons $41 / 42$ (-TICT) that was observed in three families. The Creole and Javanese ethnic groups were the most heterogeneous. Seven different mutations $[-88 \quad(C \rightarrow T) ;-29 \quad(A \rightarrow G) ;$ codons 41/42 (-TTCT); codon 47 (+A); IVS-I-849 (A>G); IVS-II-1 (G>A); - 28 (A>G); $1.393 \mathrm{~kb}$ deletion] were found in eight Creole families and four mutations in five Javanese families [IVS-I-5 (G>C); codons $8 / 9(+G)$; codon $35(-C)$; IVS-I-2 (F-C)]. Three different $\beta$-thal alleles were detected in six Hindustani families [IVS-1-5 $(G, C)$; codons $41 / 42$ (-TCC), and a $8 \beta$-thal due to a $31.6 \mathrm{~kb}$ deletion]. One family, of Lebanese origin, had the frameshift at codons $41 / 42$ (-TTCT). A unique frameshift mutation was detected in one family belonging to the Surinam Creole group [codon $47(+A)]$.

\section{INTRODUCTION}

B-Thal has a worldwide distribution with high frequencies in the Mediterranean Basin, India, Southeast Asia, and the southern part of Mainland China (1); it is believed to be rare in Western Africa. The slave trade and the migration of contract labourers from these regions have contributed to the introduction of the $\beta$-thal genes in the Surinam population. Molecular characterization of $\beta$-thal alleles have been made for the populations of the Mediterranean area, China, Southeast Asia, and India. The spectrum of $\beta$-thal mutations in these populations will likely be reflected in the immigrants living in Surinam (see Table 3b.3 for the composition of the Surinam population); $\beta$-thal alleles characteristic for Indians, Indonesians, Chinese, and Blacks can be expected to be present in Surinam. All $\beta$-thai mutations have been characterized in 20 families. The analyses involved dot-blot screening, sequencing, and gene mapping using methods described in Chapter 2. Some of the families are more extensively described elsewhere.

\section{MATERIALS AND METHODS}

3.1 Patients. Most of the patients were contacted with the help of local physicians. Patients with $\beta$-thal major and their relatives were enrolled in this study. Patients with elevated $\mathrm{Hb} \mathrm{A}_{2}$ levels, who were on record at the laboratory of the Academic Hospital, were also invited to participate. Handling of blood collections and shipment was as mentioned in Chapter 2. 
3.2 Methods. All the methods used for this study have been extensively described in Chapter 2.

\section{RESULTS}

Table 4a.l sumarizes the data oblained in this study. Thirteen different $\beta$-thal alleles were found. Two, namely the frameshift at codon 47 $(+A)$ and the $\delta \beta$-thal due to the $31.6 \mathrm{~kb}$ deletion, have not been previously reported and will be discussed in detail elsewhere in this dissertation.

TABLE 4a.1 $\beta$-Thal Mutations in the Surinam Population

\begin{tabular}{|c|c|c|}
\hline Mutation & Type & Ethnic Group \\
\hline$-29(A) G)$ & $\beta^{+}$ & Creole \\
\hline$-28(A>6)$ & $\beta^{+}$ & Jewish/Creole mix \\
\hline Codons $8 / 9(+G)$ & $\beta$ & Javanese \\
\hline Codon $35(-C)$ & $\beta^{\circ}$ & Javanese \\
\hline Codons $41 / 42$ (-TTCT) & $3^{\circ}$ & Creole; Hindustani; Javanese; Lebanese \\
\hline Codon $47(+A)$ & $\hat{p}$ & Creole \\
\hline $\begin{array}{ll}\text { IVS-I-2 } & (I>C) \\
\text { IVS-I-5 } & (6 \rightarrow C)\end{array}$ & $\hat{\beta}^{\circ}$ & $\begin{array}{l}\text { Javanese } \\
\text { Javanese; Hindustani }\end{array}$ \\
\hline IVS-II-1 (G>A) & $\beta^{\circ}$ & Creole \\
\hline IVS-II-849 $(A \rightarrow G)$ & 30 & Creole \\
\hline $\begin{array}{l}1.393 \mathrm{bp} \text { deletion } \\
31.6 \mathrm{~kb} \text { deletion }\end{array}$ & 30 & $\begin{array}{l}\text { Creole } \\
\text { Hindustani }\end{array}$ \\
\hline Codon 26 (GAG $\rightleftharpoons$ AAG) & $\hat{\beta}+$ & Javanese; Hindustani \\
\hline
\end{tabular}

\subsection{A Short Review of the Observed $\beta$-Globin Gene Defects:}

$-29(A>6)$. This $\beta^{+}$thal mutation was originally described among American Blacks (2) and Chinese (3); it was present in members of three Creole families. One member of one family had a compound heterozygosity for $H b S$ and this allele. The clinical symptoms in this child were mild, with microcytosis, elevated $\mathrm{Hb} \mathrm{A}_{2}(5.5 \%)$, and a $\mathrm{Hb} F$ level of $4.7 \%$. A compound heterozygosity for the $-29 \quad(A>6)$ and the IVS-II-849 (A)G) mutations was found in two of the three families; they will be more fully reported elsewhere in this dissertation.

$-28(A) 6)$. This 3 -thal mutation was originally found in the Chinese (4); only one Surinam family had this mutation. Two sisters in this Creole family had Jewish and Chinese admixtures. The clinical symptoms of these simple heterozygotes were as expected for promoter mutations, very mild.

Codons $8 / 9(+G)$. This $\beta^{\circ}$-thal was originally obseryed in the Asian Indian population and is also present in Turkish and Indonesian populations (5-7). One Javanese family with a compound heterozygcsity for this allele and $H b E$ was found. Detailed information about this family is given elsewhere in this dissertation. 
IYS-I-2 (T $\rightarrow C)$. This $Z^{\circ}$-thal was found in one Javanese family in combination with $\mathrm{HD} E$. Sequencing of amplified single strand DNA from one of the members revealed its detection.

IVS-I-5 (GYC). This $\hat{D}^{+}-t h a l$ allele is the most comnon $f$ thal mutation in the Asian Indian population (8). It has also been reported among Chinese (9), Malay (10), and Melanesians (11). In this study this mutation was present among the Hindustani group which originated from India (four of six families). One patient was homozygous for this mutation; this child was severely affected and transfusion-dependent. Another child from a second family had a compound heterozygosity for this allele and the $\delta \beta-t h a l$ (see Chapter 6). Members of three additional families were simple heterozygotes for this mutation.

Codon $35(-C)$. This $\beta^{+}$-thal was first reported in 1989 among Malays (10) and was later observed in Indonesians (11). Two families, both with members having a compound heterozygosity for this allele and $\mathrm{Hb} E$ were detected. The patients were anaemic but were not receiving transfusions on a regular basis (discussed el sewhere in this chapter).

Codons 41/42 (-TCT). This $3^{\circ}$-thal which is primarily found in the Chinese (12) was surprisingly found in a Creole family, a Hindustani family, and a Lebanese family. One child of the Hindustani family had a compound heterozygosity for this frameshift and $\mathrm{Hb} E$ (discussed elsewhere in this chapter). The children of the Creole family were compound heterozygotes for $\mathrm{Hb} S$ and this frameshift. Although $\mathrm{Hb}$ levels in these children were low, there were never admitted to the hospital for sickle cell crises. The - thal mutation was inherited from the father. It is known from history that the first Chinese immigrants were allowed to marry Black women; thus, the introduction of this Chinese $\beta$-thal gene likely occurred through Chinese admixture. The family had no knowledge of any racial admixture. The relatively mild clinical symptoms in the two children are difficult to understand.

Codon $47(+A)$. This $\beta^{\circ}$-thal was unique because it occurred on a chromosome that also carried a mutation in the $\delta$-globin gene and was the first time that it had been described. It was present in a large Creole family; a detailed description is given later in this chapter.

IVS-II-1 $(G>A)$. This $3^{\circ}$-thal has been reported in the Mediterranean population (13) and American Blacks (14). The patient found in our survey was first diagnosed as a homozygous SS patient with mild clinical symptoms. Our screening showed that this patient was a compound heterozygote for the IVS-II-I (G;A) mutation and $\mathrm{Hb} S$. The propositus was of Creole origin.

IVS-II-849 (A>6). The families with this condition have been described before because of their compound heterozygosities for this and the $-29(A \rightarrow 6)$ mutations.

The 1.393 bp deletion. This $\beta^{\circ}$-thal has been observed among American Blacks (15). The Creole family in which this deletion occurred had a son who was a compound heterozygote for this deletion and $\mathrm{HB} S$. A detailed description of this family is given later in this chapter. 
The $31.6 \mathrm{~kb}$ Deletion. This $\delta \hat{p}^{\circ}-$ thal was found in a Hindustani family and is discussed in detail in Chapter 6.

Codon 26 (GAGXAG). This substitution activates an alternative donor splice site at codon 26 resulting in a $\beta^{+}$-thal phenotype. The patients observed in the Surinam population were of Javanese or Hindustani origin.

\section{DISCUSSION}

The spectrum of $\beta$-thal mutations in the Surinam population is broad; this is not surprising because nearly every ethnic group is found in Surinam. Interestingly, the $-88\left(C_{7} \mathrm{~T}\right)$ allele, a mutation that is frequently found among American Blacks, was not observed in the Creole or Bush Negro groups. Other studies, conducted in The Netherlands $(16,17)$, also do not report this mutation. The majority of the hindustani patients were carriers of the IVS-I-5 (G>C) mutation, which is definitely a reflection of their Asian Indian background. No Black mutations were found in this group. The creole group is by definition a mixed ethnic group, and this is also reflected by the many different $\beta$-thal alleles that were found. Almost all $\beta$-thal mutations in the other ethnic groups could also be found in the Creole group. Prenatal diagnosis is therefore considerably more complicated for this Creole group than for Javanese or Asian Indians. Systematic screening for $\beta$-thal mutations is needed in the Surinam population because of the interaction of the mutations with the common $H b S$ and $H b E$ abnormalities; such combinations can lead to severely affected offspring. The search for $\beta$-thal alleles among the isolated inhabitants of the Bush Negro villages will be helpful in determining the original thal spectrum from the Creole group, including the newly discovered codon 47 (+A) mutation.

\section{REFERENCES}

1. Weatherall, D.J. and-Clegg, J.B.: The Thalassaemia Syndromes, 3rd edition, Blackwell Scientific Publications, 0xford, 1981.

2. Antonarakis, S.E., Orkin, S.H., Cheng, T-C., Scott, A.F., Sexton, J.P., Trusko, S., Charache, S., and Kazazian, H.H., Jr.: B-Thalassemia in American Blacks: Novel mutations in the TATA box and IVS-2 acceptor splice site. Proc. Nat1. Acad. Sci. USA, 81:1154, 1984.

3. Huang, S-Z., Wong, C., Antonarakis, S.E., Ro-Lein, T., Lo, W.H.Y., and Kazazian, H.H., Jr.: The same TATA box $\beta$-thalassemia mutation in Chinese and U.S. Blacks: Another example of independent origins of mutation. Hum. Genet., 74:152, 1986.

4. Orkin, S.H., Sexton, J.P., Cheng, T-C., Goff, S.C., Giardina, P.J.V., Lee, J.I., and Kazazian, H.H., Jr.: ATA box transcription mutation in $\mathbf{P}$-thalassemia. Nucleic Acids Res., 11:4727, 1983.

5. Kazazian, H.H., Jr., Orkin, S.H., Antonarakis, S.E., Sexton, J.P., Boehm, C.D., Goff, S.C., and Waber, P.G.: Molecular characterization of seven $\beta$ thalassemia mutations in Asian Indians. EHBO J., 3:593, 1984 .

6. Petkov, G.H., Efremov, G.D., Efremov, D.G., Dimovski, A., Tchaicarova, P., Tchaicarov, R., Rogina, B., Agarwal, S., Kutlar, A., Kutlar, F., Reese, A.L., Stoming, T.A., and Huisman, T.H.J.: $\beta$-Thalassemia in Bulgaria. Hemoglobin, 14:25, 1990. 
7. Oner, R., Altay, C., Gurgey, A., Aksoy, M., Kilins, Y., Stoming, T.A., Reese, A.L., Kutlar, A., Kutlar, F., and Huisman, T.H.J.: 3 -Thalassemia in Turkey. Hemoglobin, 14:1, 1990.

8. Treisman, R., Orkin, S.H., and Maniatis, T.: Specific transcription and RNA splicing defects in five cloned $\beta$-thalassaemia genes. Nature, $302: 591,1983$.

9. Cheng, T-C., Orkin, S.H., Antonarakis, S.E., Potter, M.J., Sexton, J.P., Giardina, P.J.V., Li, A., and Kazazian, H.H., Jr.: B-Thalassemia in Chinese: Use of in vivo RNA analysis and oligonucleotide hybridization in systematic characterization of molecular defects. Proc. Natl. Acad. Sci. USA, 81:2821, 1984.

10. Yang, K.G., Kutlar, F., George, F., Wilson, J.B., Kutlar, A., Stoming, T.A., Gonzalez-Redondo, J.M., and Huisman, T.H.J.: Molecular characterization of $\beta-g l o b i n$ gene mutations in Malay patients with $\mathrm{Hb}$ E- $\beta$ thalassaemia and thalassaemia major. Br. J. Haematol., 72:73, 1989.

11. Lie-Injo, L.E., Cai, S-P., Wahidijat, I., Moeslichan, S., Lim, M.L., Evangelista, L., Doherty, M., and Kan, Y.W.: $\beta$-Thalassemia mutations in Indonesia and their linkage to haplotypes. Am. J. Hum. Genet., $45: 971,1989$.

12. Kimura, A., Matsunaga, E., Takihara, Y., Nakamura, T., and Takagi, Y.: Structural analysis of a $\beta$-thalassemia gene found in Taiwan. J. Biol. Chem., 258:2748, 1983.

13. Treisman, R., Proudfoot, N.J., Shander, M., and Maniatis, T.: A single base change at a splice site in a $B^{\circ}$-thalassemic gene causes abnormal RNA splicing. Cell, 29:903, 1982.

14. Wong, C., Antonarakis, S.E., Goff, S.C., Orkin, S.H., Boehm, C.D., and Kazazian, H.K., Jr.: On the origin and spread of $\beta$-thalassemia: Recurrent observation of four mutations in different ethnic groups. Proc. Nat]. Acad. Sci. USA, 83:6529, 1986.

15. Padanilam, B.J., Felice, A.E., and Huisman, T.H.J.: Partial deletion of the $5^{\prime} \beta$-globin gene region causes $3^{\circ}$-thalassemia in members of an American Black family. Blood, 64:941, 1984.

16. Landman, H.: Haemoglobinopathies and pregnancy. Thesis, Groningen, 1988.

17. Huisman, T.H.J.: Molecular pathology of the hemoglobinopathies including the thalassemias; some examples observed in the population of The Netherlands. in De Wetenschappelijke Betekenis van Hematologisch Onderzoek, edited by P. Sonneveld and J. Lindemans, page 27, Universiteits Erasmus Drukkerij, Rotterdam, 1990. 
CHAPTER 4b

COMPOUND HETEROZYGOSITY FOR A MILD $\beta^{+}$AND RARE $\beta^{\circ}-$ THALASSEMIA ALLELE (Adapted from: Acta Haematol., 84:135-138, 1990) 


\title{
COMPOUND HETEROZYGOSITY FOR A MILD $\hat{p}^{+}$
}

\author{
AND A RARE $\tilde{\rho}^{\circ}$-THALASSEMIA ALLELE
}

J. Codrington1,2, J. Anijs', J.H. Misse2, F.A. Codrington2, H. Lil, F. Kutlarl, M. Ramachandran', and T.H.J. Huisman

1 Department of Cell and Molecular Biology

Medical College of Georgia

Augusta, GA 30912-2100, U.S.A.

2 University Hospital, Paramaribo, Surinam

(Adapted from: Acta Haematol., 84:135-138, 1990.)

\section{ABSTRACT}

Haematological and $\mathrm{Hb}$ composition data are presented for 14 members of a Surinam family (and for one unrelated subject) with either a $\beta$-thal heterozygosity [five with the -29 (A>S) $\beta^{+}$mutation and five with the IVS-II-849 (A>6) $3^{\circ}$ mutation] or a compound heterozygosity (the five remaining patients). Identification of the mutation was by hybridization of amplified DNA with 32p-labelled synthetic oligonucleotides. The data indicate distinct differences between the two groups of heterozygotes, mainly in degree of microcytosis and hypochromia, in $\mathrm{Hb} \mathrm{A}_{2}$ levels, and in the level of Gr (high in the -29 heterozygotes and low in the IVS-II-849 heterozygotes). The five compound heterozygotes had a thalassaemia intermedia with high $\mathrm{Hb} F$ levels (high $\mathrm{G}_{\mathrm{y}}$ ), elevated $\mathrm{Hb} \mathrm{A}_{2}$, and $\mathrm{Hb} A$ levels comparable to those seen in patients with a homozygosity for the -29 mutation or with the combination of this $\mathcal{\beta}^{+}$-thal and $H b S$. An $\alpha$-thal-2 heterozygosity (-3.7 kb deletion) was present in two patients. Their haematological data were improved over those for the patients with four $\alpha-g$ lobin genes; one was the mother of two sets of twins. The high $G \gamma$ value in the $H b F$ of the compound heterozygotes suggests that the high $\mathrm{Hb} F$ production in the condition is mainly directed by the chromosome with the -29 (A)6) mutation.

\section{INTRODUCTION}

Modern methodology has made it possible to rapidly identify the various \$-thal alleles, of which more than 80 have been described thus far (1). Many surveys have been undertaken in different countries with data important for diagnosis and treatment (for review see Ref. 2). Occasionally, some interesting families participate in these studies and the data collected provide detailed information about the disease that is present. This is the case for a large Surinam family in which two different $\beta$-thal alleles interact; this report.provides details of this study. 


\section{MATERIALS AND METHODS}

Blood samples from 15 members of this family and from an unrelated double heterozygote wcre collected in vacutainers with EDTA as anticoagulant and shipped in wet ice by a special courier service from Paramaribo, Surinam to Augusta, GA. Informed consent was obtained.

Haematological data were obtained with an automated cell counter; the samples were 5 days old at the time of analysis. $H b F, H b A_{2}$, and $H b A$ were quantitated by cation exchange HPLC using a polyCAT column $(3,4)$. The relative quantities of $G_{\gamma}$ and $A_{\gamma}$ in the $H b F$ were determined by reversed phase HPLC $(5,6)$; DEAE-cellulose chromatography (7) was used to isolate the $H b F$ from the blood samples of the simple heterozygotes.

DNA was is isolated from the white cells by the method of Poncz et al (8). $\alpha$-Globin gene mapping analyses used procedures that are standard in our laboratories $(9,10)$. Identification of the $\beta$-thal mutations was by dot-blot analysis of amplified DNA with $32 \mathrm{p}-1$ abelled synthetic oligonucleotides; this procedure has been described in detail before $(11,12)$.

\section{RESULTS}

4.1 The Family. Three generations of this Creole family participated in the study; the pedigree is given in Fig. $4 \mathrm{~b} .1$. The grandmother (I-2) has a twin sister and there are three additional sets of dizygotic twins in this family. All members are in good health except for the double heterozygotes (see below), although none received regular blood transfusions. Subject 11-3, mother of two sets of twins, is a teacher and works full-time. One person (II-5) is normal.

I.

II.

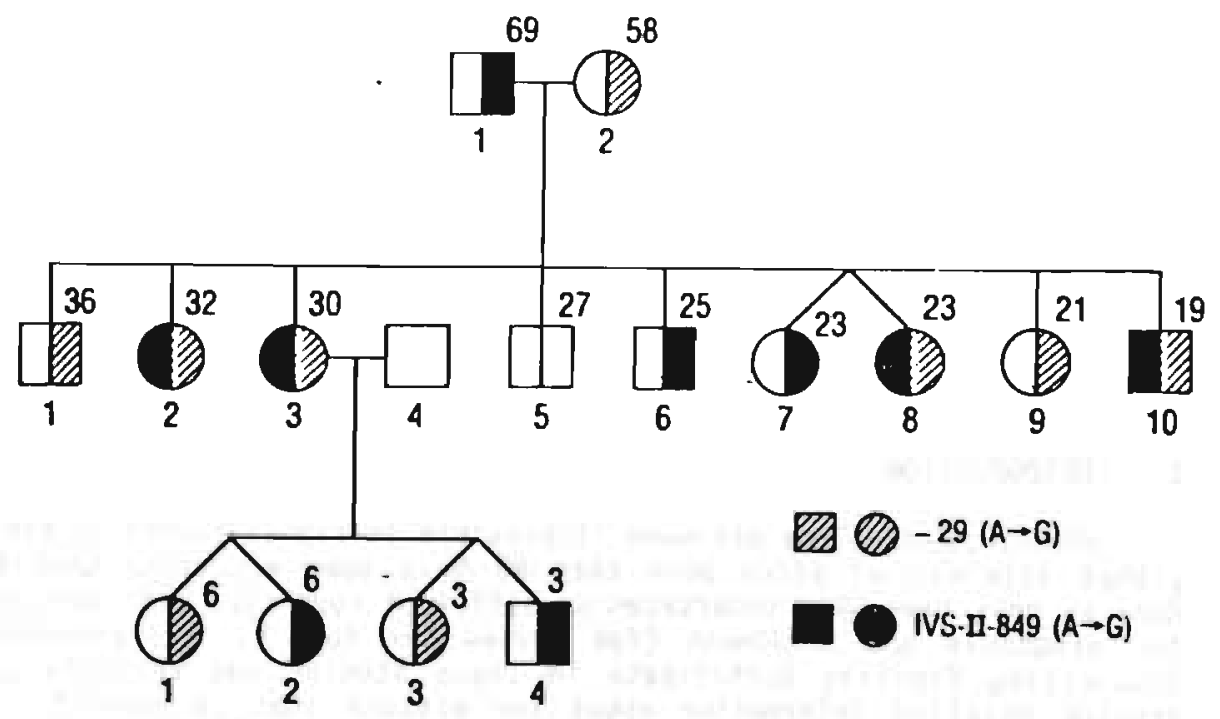

FI6. 4b.1 Pedigree of the Creole family (F) from Surinam. 
4.2 Identification of the $\beta$-Thal Alleles and the Type of $\alpha$-Thal. Dotblot analyses readity identified the $A \rightarrow G$ promoter mutation at position -29 in five heterozygotes $(1-2 ; 11-1 ; 11-9 ; 111-1 ; 111-3)$ and in five compound heterozygotes (II-2; II-3; 1]-8; 11-10, and the unrelated adult identified by 556$)$. This mutation is the most conmon transcriptional mutant observed in Blacks $(13,14)$. The second mutation is a rare -thal allele and is characterized by an A G mutation at position 849 of the second intron; it was present in subjects $I-1 ; 11-6 ; 11-7 ; 1 I I-2 ; 1 I I-4$, and in the five patients with a compound heterozygosity. This RNA processing mutant was first described in 1984 (13) and has been observed only a few times thereafter $(15,16)$.

The possible presence of an $\alpha$-thal was evaluated in all but two of the participants. Six subjects had a heterozygosity for $\alpha$-thal-2 $[-\alpha$ $(-3.7) / \alpha \alpha]$, while the others had four $\alpha-g$ lobin genes.

4.3 Haematological and $\mathrm{Hb}$ Composition Data. These results are 1 isted in Table $4 \mathrm{~b} .1$ and include the $\mathrm{Hb} \mathrm{A}_{2}, \mathrm{Hb} F$, and $\mathrm{Hb} A$ levels, the $2 \mathrm{G}_{\gamma}$ ir $H b F$, and the number of $\alpha$-globin genes. The data are arranged in such a way that a comparison between $-29(A \rightarrow G) \beta^{+}$-thal heterozygotes, IVS-II -849 $(A>G) \beta^{\circ}$-thal heterozygotes, and compound heterozygotes is facilitated. The results are of some special interest because each group had the same number of patients of variable ages and of different sexes. The data do not appear to be significantly altered by the age of the samples except perhaps for the $\mathrm{MCV}$ values.

\section{Discussion}

The rapid advances in the methodology have made it possible to identify the precise nature of the various -thalassemic conditions, providing an insight into the clinical variations that have been observed. The data obtained in the present study are of interest because detailed comparisons between two different $\beta$-thalassemia alleles can be made among members of a large family.

As shown in table 1, tha data for the two sets of $\beta$-thalassemia heterozygotes are not very different except for the high level of ${ }^{G} \gamma$ in the -29 heterozygotes (average $61.9 \%$ ) and the low level in the IVS II-849 heterozygotes (average 28.4\%). This difference can be explained by the presence of an Xmn I site $5^{\prime}$ to ${ }^{G} \gamma(T$ at position -158) on the chromosome carrying the $A \rightarrow G$ at mutation -29 while this is site absent (C at position -158) on the chromosome with the $A \rightarrow G$ (IVS II-849) mutation (16). Other differences include a more severe microcytosis and hyperchromia and slightly higher Hb A2 values for IVS II-849 heterozygotes (average $\mathrm{Hb}: 5.7$ versus 5,05\% for the -29 heterozygote). The effect of an $\alpha$ thalassemia-2 heterozygosity on the data collected is negligible except perhaps for slightly higher $\mathrm{Hb} F$ values in the adults with four $\alpha$ globin genes. 
The data for the five compound heterozygotes, also listed in Table 4b.1, deserved several comments. None of these adults required any transfusions; subject II-3 was the mother of two sets of twins. Subject II-10 was ill with severe infections at the time of blood collection; apparently a $\mathrm{Hb}$ level between 7 and $9 \mathrm{~g} / \mathrm{dl}$ can be maintained. The condition and the haematological values of subjects II-2 and II-3 are considerably better than those of the other three patients. It appears likely that the coexisting $\alpha$-tha1-2 heterozygosity is the major contributing factor reducing the otherwise rather severe $\alpha /$ non- $\alpha$ imbalance. Except for the results obtained for patient II-8, the $H b$ composition data for the remaining four patients are very similar; the $\mathrm{Hb} \mathrm{A}_{2}$ value is elevated (average $4.8 \%$ ), the $\mathrm{Hb} \mathrm{A}$ values are nearly the same (average $18.5 \%$; range $17.9-18.5 \%$ ), and $H b F$ is the major $H b$ type (average $76.7 \%$ ). A comparison of the data for patients II-2 and II-3 with those for patients $I I-10$ and $\$ 556$ indicate that the presence of the $\alpha$-thal-2 heterozygosity does not modify these values. The synthesis of the $B A$ chain is regulated by the chromosome with the -29 (A7G) mutation; the average value of $18.5 \%$ observed for our patients is comparable to the values observed in patients with either a homozygosity for this mutation (12) or a heterozygosity in combination with Hb S (19). The Or value in the Hb F of all five subjects was high (average 69.8\%); this likely suggest that the synthesis of the $G_{\gamma}$ and $A_{\gamma}$ chains in these patients is primarily regulated by the chromosome with the $-29(A \rightarrow 6)$ mutation.

The unusual data observed for patient II-8, i.e. the low $\mathrm{Hb} \mathrm{A}_{2}$ and $\mathrm{Hb}$ A values, can at present not be explained and repeat analyses will be in order. 
$\begin{array}{cccccccccccc}\text { Casea } & \text { Sex- } & H b & P C V & R B C & M C V b & M C H & M C H C & A 2 & F & A & G y\end{array} \alpha$

A. Heterozygotes for the $-29(A \rightarrow G)$ Mutation

$\begin{array}{crrrrrrrrrrrr}\text { I-2 } & \text { F-58 } & 10.2 & .445 & 4.89 & 91 & 20.9 & 22.9 & 5.0 & 1.1 & - & 70.0 & 4 \\ \text { II-1 } & \text { M-36 } & 11.5 & .495 & 4.80 & 103 & 24.0 & 23.2 & 5.3 & <1.0 & - & 51.7 & 3 \\ \text { II-9 } & \text { F-21 } & 9.9 & .410 & 4.13 & 99 & 24.0 & 24.1 & 5.0 & 1.6 & - & 62.9 & 4 \\ \text { III-1 } & \text { F- } 6 & 9.7 & .435 & 5.00 & 87 & 19.4 & 22.3 & 5.3 & 1.9 & - & 54.9 & - \\ \text { III-3 } & \text { F- 3 } & 12.2 & .510 & 5.42 & 94 & 22.5 & 23.9 & 4.7 & 11.6 & - & 54.9 & 4\end{array}$

B. Heterozygotes for the IVS-II-849 (A>G) Mutation

\begin{tabular}{rrrrrrrrrrrrr}
\hline I-1 & M-69 & 11.0 & .540 & 5.87 & 92 & 18.7 & 20.4 & 5.5 & $<1.0$ & - & 20.0 & 3 \\
II-6 & M-25 & 12.1 & .510 & 6.10 & 84 & 19.8 & 23.7 & 5.8 & $<1.0$ & - & 30.0 & 3 \\
II-7 & F-23 & 11.0 & .470 & 5.62 & 84 & 19.6 & 23.4 & 5.3 & 1.9 & - & 32.1 & 4 \\
III-2 & F- 6 & 10.1 & .440 & 5.11 & 86 & 19.8 & 23.0 & 6.4 & 2.1 & - & 28.0 & 3 \\
III-4 & F- 3 & 9.9 & .435 & 5.38 & 81 & 18.4 & 22.8 & 5.6 & 4.5 & - & 32.0 & -
\end{tabular}

C. Compound Heterozygotes for the $[-29(A>G) / I V S-I I-849(A>G)]$ Mutations

\begin{tabular}{lllllllllllll}
\hline II -2 & $F-32$ & 8.2 & .305 & 4.10 & 74 & 20.0 & 26.9 & 5.1 & 76.9 & 18.0 & 70.6 & 3 \\
II-3 & $F-30$ & 9.1 & .275 & 3.54 & 78 & 25.7 & 33.1 & 4.2 & 77.3 & 18.5 & 65.7 & 3 \\
II-8 & $F-23$ & 8.4 & .330 & 4.11 & 80 & 20.4 & 25.5 & 2.0 & 86.1 & 11.9 & 67.2 & 4 \\
II-10 & M-19 & 4.7 & .215 & 2.55 & 84 & 18.4 & 21.9 & 4.7 & 75.8 & 19.5 & 72.4 & 4 \\
\#556f & M-36 & 7.0 & .285 & 3.54 & 81 & 19.8 & 24.6 & 5.1 & 77.0 & 17.9 & 73.0 & 4
\end{tabular}

a See pedigree in Fig. $4 b .1$.

b The unusually high MCV values are due in part to the age of the blood samples ( 5 days in transit).

c By polyCAT HPLC $(3,4)$.

d By reversed phase HPLC $(5,6)$.

e The diagnosis in this girl is based on Hb composition data only.

$f$ Unrelated to the family shown in the pedigree of Fig. $4 \mathrm{~b} .1$.

\section{ACKNOMLEDGEMENTS}

This research was in part supported by the United States Public Health Service Research Grants HLB-05168 and HLB-41544. This is contribution \#1236 from the Department of Cell and Molecular Biology at the Medical College of Georgia in Augusta, Georgia.

\section{REFERENCES}

1. Kutlar, A.: ₹-Thalassemia Repository. Hemoglobin, 13:775, 1989.

2. Huisman, T.H.J.: Frequencies of common $\beta$-thalassaemia alleles among different populations; variability in clinical severity. Br. J. Haematol., 76:454, 1990. 
3. Bisse, E. and Wieland, H.: High performance liquid chromatographic separation of human hacnoglobins - Simultaneous quantitation of foetal and glycated haenoglobins. J. Chromatogr., 434:95, 1988.

4. Kutlar, A., Kutlar, F., Gu, L.G., Mayson, S.M., and Huisman, T.H.J.: Fetal hemoglobin in normal adults and $\beta$-thalassemia heterozygotes. Hum. Genet., 85:106, 1990.

5. Sheiton, J.B., Sheiton, J.R., and Schroeder, W.A.: High performance liquid chromatographic separation of globin chains on a large-pore $\mathrm{C}_{4}$ column. J. Liq. Chromatogr., 7:1969, 1984.

6. Kutlar, F., Kutlar, A., and Huisman, T.H.J.: Separation of normal and abnormal hemoglobin chains by reversed phase high performance liquid chromatography. J. Chromatogr., 357:147, 1986.

7. Huisman, T.H.J. and Jonxis, J.H.P.: The Hemoglobinopathies Techniques of Identification, Clinical and Biochemical Analysis, Vol. 6, Marcel Dekker, Inc., New York, 1977.

8. Poncz, M., Solowiejczyk, D., Harpel, B., Mory, Y., Schwartz, E., and Surrey, S.: Construction of human gene libraries from small amounts of peripheral blood: Analys is of -like globin genes. Hemoglobin, $6: 27,1982$.

9. Felice, A.E., Cleek, M.P., McKie, K., McKie, V., and Huisman, T.H.J.: The rare $\alpha$-thalassemia-1 of Blacks is a $z \alpha$-thalassemia- 1 associated with a deletion of all $\alpha$ - and $z$-globin genes. Blood, 63:1253, 1984.

10. Felice, A.E., Cleek, M.P., Marino, E.M., McKie, K., McKie, V.C., Chang, B.K., and Huisman, T.H.J.: Different $z$ globin gene deletions among Black Americans. Hum. Genet., 73:221, 1986.

11. Diaz-Chico, J.C., Yang, K.G., Stoming, T.A., Efremov, D.G., Kutlar, A., Kutlar, F., Aksoy, M., Altay, C., Gurgey, A., Kilins, $Y$, and Huisman, T.H.J.: Mild and severe $\beta$-thalassemia among homozygotes from Turkey: Identification of the types by hybridization of amplified DNA with synthetic probes. Blood, 71:248, 1988.

12. Ali, M.A.M., Pinkerton, P., Chow, S.W.S., Zaetz, S.D., Wilson, J.B., Webber, B.B., Hu, H., Kutlar, A., Kutlar, F., and Huisman, T.H.J.: Some rare hemoglobin variants with altered oxygen affinities: Hb

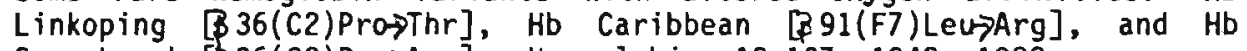
Sunnybrook [3 36(C2)Pro>Arg]. Hemoglobin, 12:137, 1948, 1988.

13. Antonarakis, S.E., Orkin, S.H., Cheng, T.C., Scott, A.F., Sexton, J.P., Trusko, S., Charache, S., and Kazazian, H.H., Jr.: \$-Thalassemia in American Blacks: Novel mutations in the TATA box and IVS-2 acceptor splice site. Proc. Nat1. Acad. Sci. USA, 81:1154, 1984.

14. Huang, S.Z., Wong, C., Antonarakis, S.E., Ro-lein, T., Lo, W.H.Y., and Kazazian, H.H., Jr.: The same TATA box $\beta$-thalassemia mutation in Chinese and U.S. Blacks: Another example of independent origins of mutations. Hum. Genet., 74:152, 1986.

15. Atweh, G.F., Anagnou, N.P., Forget, B.G., and Kaufman, R.E.: $\beta$-Thalassemia resulting from a single nucleotide substitution in an acceptor splice site. Nucleic Acids Res., 13:777, 1985.

16. Gonzalez-Redondo, J.M.: Unpublished data.

17. Gilman, J.G. and Huisman, T.H.J.: ONA sequence variation associated with elevated fetal Go globin production. Blood, 66:783, 1985.

18. Gonzalez-Redondo, J.M., Kutlar, F., Kutlar, A., Stoming, T.A., de Pablos, J.Ma., Kilins, Y., and Huisman, T.H.J.: Ho S(C)-Bt-thalassaemia: Different mutations are associated with different levels of normal Hb A. Br. J. Haematol., 70:85, 1988. 
CHAPTER 4C

OBSERVATIONS ON THE LEVELS OF HB A2 IN PATIENTS WITH DIFFERENT $\beta$-THALASSEMIA MUTATIONS AND A $\delta$ CHAIN VARIANT (Adapted from: Blood, 76:1246-1249, 1990) 


\section{0}


OBSERVATIONS ON THE LEVELS OF HB $A_{2}$ IN PATIENTS WITH

DIFFERENT $\beta$-THALASSEMIA MUTATIONS AND A $\delta$ CHAIN VARIANT

J.F. Codrington, H-H. Li, F. Kutlar, L-H. Gu,

M. Ramachandran, and T.H.J. Huisman

Department of Cell and Molecular Biology

Medical College of Georgia

Augusta, GA 30912-2100, U.S.A.

(Adapted from: Blood, 76:1246-1249, 1990)

\section{ABSTRACT}

$\mathrm{Hb} A_{2}$ and its variant $\mathrm{Hb} A_{2}{ }^{\prime}$ or $B_{2}\left[\delta 16(A 13) G_{1} \gg A_{A}\right.$ arg] were quantitated in the blood of subjects with three different types of $\beta$-thal, and with the $\delta-B_{2}$ anomaly in cis or in trans to the $\beta$-thal determinant. In one family, the $\delta-B_{2}$ mutation was in cis to a newly discovered codon $47(+A)$ frameshift. The levels of $\mathrm{Hbs} \mathrm{A}_{2}$ and $B_{2}$ were nearly the same and about $70 \%$ higher than those in simple $\mathrm{Hb} \mathrm{B}_{2}$ heterozygotes. In two additional families, the $\delta-B_{2}$ variant was in trans to either a deletional $\beta$-thal (1392 bp) involving part of the $\beta-g$ lobin gene and part of the $\beta$-globin gene promoter, or to the $-88\left(C-C^{\top}\right)$ promoter mutation. In both instances, the $\mathrm{Hb} \mathrm{B}_{2}$ level was increased by $80 \%$, but the $\mathrm{Hb} A_{2}$ level was increased by $\sim 270$ and $\sim 200 \%$, respectively. These data indicate two mechanisms that will cause an increase in $\delta$ chain production. One is consistent with a general mechanism concerning the relative excess of $\alpha$ chains in $\beta$ chain deficiencies which will combine with $\delta$ chains to form variable levels of $\mathrm{HD}_{2} A_{2}$ dependent upon the severity of the $\beta$ chain deficiency. The second concerns the loss of $\beta$-giobin gene promoter activity, perhaps by an absence of (or decreased) binding of (a) specific protein(s) to this segment of DNA, and a concomitant increase in $\delta$-globin gene promoter activity in cis.

\section{INTRODUCTION}

The increase in the level of $H b A_{2}$ in $\beta$-thal heterozygotes was discovered in 1957 when the percentage of $\mathrm{Hb} \mathrm{A}_{2}$ was found to be about twice that in normal adults (1). More recent studies have indicated that the relative increase depends upon the type of $\beta$-thal that is present. For instance, carriers of some mild types of $\beta$-thal such as those caused by the $C \rightarrow$ T mutation at IVS-I-6 (2) or by $A \rightarrow G$ mutations in the poly A site (3), have only slight increases in their $\mathrm{Hb}_{2} \mathrm{~A}_{2}$ levels (4). These observations are consistent with the concept that $\alpha$ chains combine much more readily with the $\beta$ chain of $H b A$ than with the $\delta$ chain of $H b A_{2}$, and that in conditions with variable $\beta$ chain deficiencies, the increase in $\mathrm{Hb}_{2} \mathrm{~A}_{2}$ level should 
vary accordingly (5). However, there are exceptions to this rule; for instance, persons with a heterozygosity for either one of two mild promoter mutations, namely the $C \rightarrow T$ at position -88 or $A \rightarrow G$ at position -29 , which are coriknon among Blacks (6), have $\mathrm{Hb} \mathrm{A}_{2}$ values at least as high as those observed among heterozygotes for the more severe $\hat{\beta}$-thal alleles like the $C \rightarrow T$ mutation at codon 39 or the G $\rightarrow$ mutation at IVS-I-110 present in Mediterranean patients $(2,6)$. Furthermore, $\beta$-thal heterozygotes with a $\delta$ chain variant like $\delta-B_{2}$ in cis or in trans to the thalassaemia mutation have similar amounts of $\mathrm{Hb} \bar{A}_{2}$ and the variant (7-9), indicating that the increased $\mathrm{Hb} A_{2}$ synthesis in $\beta$-thal is derived from $\delta$ genes, both in cis and in trans to the $\beta$-thal mutation.

Unusually high $\mathrm{Hb} \mathrm{A}_{2}$ levels of $7-9 \%$ have been found in $\beta$-thal heterozygotes with a deletional defect that involves the $5^{\prime}$ segment of the $\beta$-globin gene and (part of) the $3-g l o b i n g e n e$ promoter (10-12). The deletions concern a 292 bp deletion observed in a Turkish family $(11,13)$, a 1392 bp deletion observed among Blacks $(10,13,14)$, and the much larger 4237 bp deletion seen in members of a Czechoslovakian family (12); all types share the loss of the 5 ' 3 promoter. We recently detected a 3 -thal heterozygote from Surinam who had the 1392 bp deletion and a $\mathrm{Hb} \mathrm{B}_{2}$ heterozygosity, and who exhibited disproportionate levels of $\mathrm{Hb}_{2}$ and $\mathrm{Hb} \mathrm{B}_{2}$. This observation prompted us to reevaluate some members of two families with both $\beta$-thal and $\mathrm{Hb} \mathrm{B}_{2}$ heterozygosities who were described over 25 years ago $(7,8)$.

\section{MATERIALS AND METHODS}

3.1 Blood Samples. Samples from three members of Family K (7) and from four members of a second Black family (Family M) were collected in The Netherlands (two samples) and in Surinam (five samples) and shipped by air to Augusta, GA. Blood samples from one Black male of Family $R$ (8), his 6-year-old twin daughters, and from a fourth, unrelated adult Black female, were obtained locally. Collection was in vacutainers with EDTA as anticoagulant. Informed consent was obtained.

3.2 Methods. Haematological data were collected with an automated cell counter. $\mathrm{Hb} F$ was quantitated by cation exchange HPLC using the PolyCAT column system $(2,15)$. $\quad \mathrm{Hb} \mathrm{A}_{2}$ and $\mathrm{Hb} \mathrm{B}_{2}$ were quantitated by the same PolyCAT HPLC procedure and by the analytical DEAE-cellulose procedure with Tris-KCN-HCl developers and a $\mathrm{pH}$ gradient (16); a similar method was used in the earlier publication describing some of these individuals $(7,8)$.

DNA was isolated from white blood cells with the method described by Poncz et al (17). Identification of the $\mathrm{Hb} \mathrm{B}_{2}$ variant was by hybridization of amplified DNA (18) with probes specific for a $6 \times C$ mutation in codon 16 of the $\delta$-globin gene. A similar procedure was used to identify one of the 3-thal mutations; methodology has been described in previous publications (13). The $\sim 1.4 \mathrm{~kb}$ deletion present in the third family was detected by gene mapping as shown earlier $(11,13)$. The mutation in the third family was new and was identified through sequencing of amplified DNA (13). It was confirmed by hybridization of amplified DNA with a specific, radiolabelled, oligonucleotide probe. 
4.1 The Three Families and Their $\beta$-Thal Types. Family $K$ is of DutchSurinam origin and was first described in 1961 (7). Fourteen members with a $\beta$-thal heterozygosity also had a heterozygosity for $\mathrm{Hb} \mathrm{B}_{2}$; no normal menibers carried the $\mathrm{Hb}_{\mathrm{B}} \mathrm{B}_{2}$ variant and no $\beta$-thal heterozygote was without it. This observation was explained by assuming that the two abnormalities were linked and occurred on the same chromosome. The average values for $\mathrm{Hb}_{2}(2 \%)$ and $\mathrm{Hb} \mathrm{B}_{2} 1.9 \%$ ) were only slightly less than the average $\mathrm{Hb}_{2}$ value (2.2\%) for 12 normal family members [measured by CMcellulose chromatography (16)]. Nearly 30 years later it was possible to obtain blood samples from three $\beta$-thal heterozygotes (listed in Table $4 c .1$ ). The $\beta$-thal mutation in this family had not been observed before and was identified through sequencing as a frameshift in codon $47(+A)$, which was confimed by hybridization of amplified DNA with appropriate probes (Fig. 4c.1).

TABLE 4C.1 The Levels of $\mathrm{HbS} \mathrm{A}_{2}$ and $\mathrm{B}_{2}$ in $\mathrm{Hb} \mathrm{B}_{2}$ Heterozygotes With and Without an Additional $\beta$-Thal Heterozygosity

\begin{tabular}{|c|c|c|c|c|c|c|c|}
\hline \multirow[b]{2}{*}{ Subjecta } & \multirow[b]{2}{*}{$\begin{array}{l}\text { Sex- } \\
\text { Age }\end{array}$} & \multicolumn{3}{|c|}{ DEAE-Cellulose Chromatogr. } & \multirow[b]{2}{*}{$\mathrm{B}_{2}$} & \multicolumn{2}{|c|}{ PolyCAT HPLC } \\
\hline & & $\begin{array}{cc}B_{2} & A_{2} \\
\% & { }^{2}\end{array}$ & $\underset{x}{T o t a l}$ & $\frac{100 \cdot B_{2}}{\text { Total }}$ & & $\begin{array}{c}\mathrm{A}_{2} \\
2\end{array}$ & Tota $\frac{1100 . B_{2}}{\text { Total }}$ \\
\hline
\end{tabular}

Family K; Hb B2 in cis; $\beta$-thal mutation; codon $47(+A)$

\begin{tabular}{ll|llll|llll} 
S.K. (IV-1) & F-36 & 1.98 & 2.51 & 4.49 & 44.1 & 2.55 & 2.60 & 5.15 & 49.5 \\
H.R. (III-4) & M-64 & 2.52 & 2.72 & 5.24 & 48.1 & 2.36 & 2.45 & 4.81 & 49.1 \\
E.C.R. (III-2) & F-60 & 1.71 & 2.36 & 4.07 & 42.0 & 2.32 & 2.41 & 4.73 & 49.0 \\
$\quad$ Average & & $\underline{2.07}$ & $\underline{2.53}$ & $\underline{4.60}$ & $\underline{45.0}$ & $\underline{2.41}$ & $\underline{2.49}$ & $\underline{4.90}$ & $\underline{49.2}$
\end{tabular}

Family $\mathrm{R} ; \mathrm{Hb} \mathrm{B}_{2}$ in trans; $\mathrm{B}$-thal mutation; $-88(\mathrm{C}-\mathrm{T})$
E.R. $(11-2)$
M-39
2.17
4.39
6.56
\begin{tabular}{l|l}
33.1 & 2.52 \\
$34: 1$ & 2.57
\end{tabular}
4.49
$7.01 \quad 35.9$ 2nd collection
2.46
$4.75 \quad 7.21$
4.47
7.0436 .5

Family $M ; \mathrm{Hb} \mathrm{B}_{2}$ in trans; $\beta$-thal mutation; 1392 bp deletion

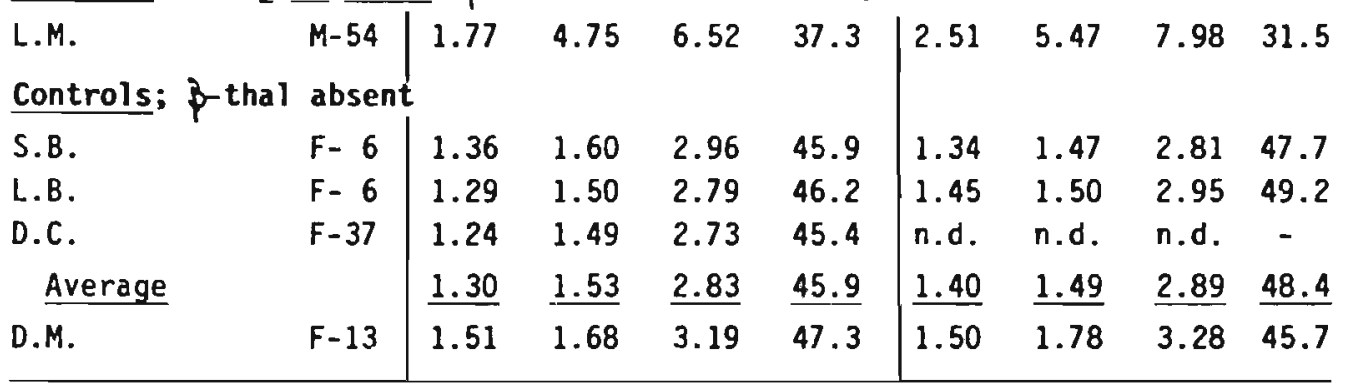

a Numbers between parentheses identify the numbers in the pedigrees as published in 1961 (7) and 1963 (8). The controls S.B. and L.B. are the twin daughters of E.R. of Family R. The control D.M., who is the daughter of L.M, has an additional $\mathrm{Hb} S$ heterozygosity; the value for $\mathrm{Hb} \mathrm{A}_{2}$ with the PolyCAT HPLC procedure may be slightly too high because of contamination with a minute quantity of modified $\mathrm{Hb} S$. 


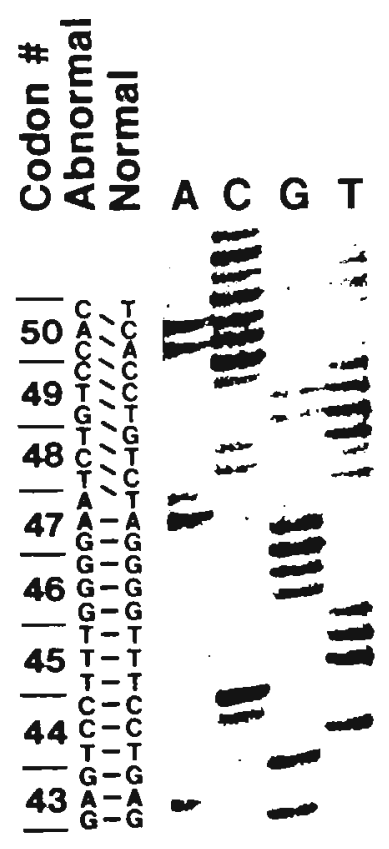

\title{
Mutant Normal
}

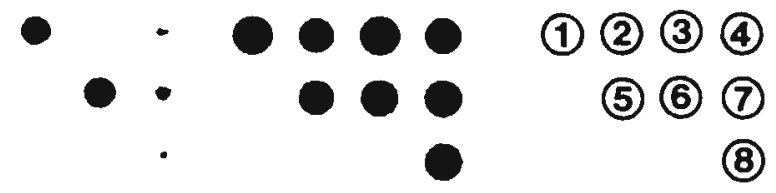

\section{Probes}

\author{
Normal: $\quad$ 5'-CTTTGGGGA - TCTGTCCACT-3' \\ Mutant: $\quad$ 5'-CTTGGGGA A TCTGTCCAC -3'
}

FIG. 4 c.1 Identification of the frameshift at codon $47(+A)$ of the $\beta$ chain leading to a $\beta^{\circ}$-thal. Left: Part of a sequencing gel locating the frameshift at codon $\overline{47}(+A)$. Right: Confirmation of the codon $47(+A)$ frameshift by hybridization of the amplified DNA with 32 p-labelled probes.

Family $R$ is a Black family from Central Georgia, described in 1963 (8), because $H b C[\beta 6(A 3) G l u \rightarrow L y s], \beta$-thal, and $H b B_{2}$ occurred in different combinations. One subject, E.R., had the $\$$-thal and $\mathrm{Hb}_{2} \mathrm{~B}_{2}$ heterozygosities; family studies showed that the two anomalies were not linked and occurred on opposite chromosomes. Subject E.R. had $1.85 \% \mathrm{Hb} \mathrm{B}_{2}$ and a rather high $\mathrm{Hb} \mathrm{A}_{2}$ level of $2.7 \%$, while his mother with a simple $\mathrm{Hb}_{2} \mathrm{~B}_{2}$ heterozygosity had $1.15 \%$ $\mathrm{Hb} \mathrm{B}_{2}$ and $1.25 \% \mathrm{Hb} \mathrm{A}_{2}$. He was reevaluated 26 years later; his twin daughters, 6 years of age, were found to have a simple $\mathrm{Hb} \mathrm{B}_{2}$ heterozygosity. The p-thal mutation in this family was the second most common type found in Blacks, 1.e. the $C T$ mutation at $n t-88$ of the $\beta$-globin gene promoter (11); details of this characterization are not presented.

Family $M$ from Surinam consisted of parents and two children. The father had a $\mathrm{Hb} \mathrm{B}_{2}$ trait and a $\mathrm{P}$-thal heterozygosity, the mother a $\mathrm{Hb} S$ trait, one child had $H b S-\beta^{\circ}$-thal, and the other child had Hb $S$ trait combined with a $\mathrm{Hb} \mathrm{B}_{2}$ heterozygosity. The $\beta$-thal was identified as the $1392 \mathrm{bp}$ deletion with a $5^{\prime}$ end point $N 600$ bp $5^{\prime}$ to the Cap site and a $3^{\prime}$ end point $\sim 500$ bp from the $5^{\prime}$ splice Junction of IVS-II $(10,13)$. Details of the study of Family $\mathrm{M}$ will not be presented. 
The $G \times C$ mutation in codon 16 of the : globin gene leading to the synthesis of the lchain of $\mathrm{Hb} \mathrm{B}_{2}$ was confirmed for all three families through hybridization of amplified DNA with 32p-labelled oligonucleotide probes.

4.2 The Percentages of $\mathrm{Hb}$ Afand $\mathrm{Hb} \mathrm{B}_{2}$. Quantitation was with two procedures. The DEAE-cellulose chromatographic method resembled that used in the older experiments $(7,8)$; it had the disadvantage of a decreased recovery of $\mathrm{Hb} \mathrm{B}_{2}$, particularly in somewhat older red cell lysates. The data obtained with the PolyCAT HPLC method were highly reproducible, even after storage of the samples at $4^{\circ} \mathrm{C}$ for an extended period of time. The percentages determined with both procedures are listed in Table 4c.1; although the absolute values given for some samples in the two groups differ considerably, the relative quantities for $\mathrm{Hb}_{2}$ and $\mathrm{Hb} \mathrm{A}_{2}$ (1) isted as 100. $B_{2}$ /totall were similar.

The percentages of $\mathrm{Hbs} A_{2}$ and $B_{2}$ in the three members of Family $K$ with the codon $47(+A)$ frameshift mutation were nearly the same, confirming previously published results (7). The average PolyCAT values of 2.41 and $2.49 \%$ were about $70 \%$ higher than the average values of 1.40 and $1.49 \%$ observed for two $\mathrm{Hb} \mathrm{B} \mathrm{B}_{2}$ heterozygotes. Subject $\mathrm{E} . \mathrm{R}$. With the $-88(\mathrm{C} \rightarrow \mathrm{T})$ mutation averaged $2.55 \%$ for $H b B_{2}$ and $4.48 \%$ for $H b A_{2}$; this corresponds to an 80 and a $200 \%$ increase over the levels in the $\mathrm{Hb} \mathrm{B}_{2}$ heterozygotes. The total value of $7.03 \%$ for $\delta$ chain-containing $H b$ types was high; the average value for $\mathrm{Hb} \mathrm{A}_{2}$ in $10 \mathrm{~B}$-thal heterozygotes with the same mutation was $5.4 \pm 0.4 \%$ with a range of 4.5 to $6.6 \%$ (unpublished data). The level of $\mathrm{Hb} \mathrm{B}_{2}$ in L.M. of Family $\mathrm{M}$ with the 1392 bp deletion was $2.51 \%$ and that of $\mathrm{Hb} \mathrm{A}_{2}$ was $5.47 \%$, in increase of $\sim 80$ and $\sim 270 \%$ over the values for $\mathrm{Hbs}_{2}$ and $A_{2}$ in the $\mathrm{Hb} B_{2}$ heterozygotes. The level of $7.98 \%$ for $\delta$ chain-containing $H b$ types is similar to values observed for other patients with the same deletion $(6,10,13)$. The values for $\mathrm{Hbs} A_{2}$ and $B_{2}$ in the one non-thalassaemic member of this family, who also had a $H b S$ heterozygosity, were nearly the same.

\section{DISCUSSION}

The results obtained in this study and summarized in Table $4 c .1$, suggest the following: 1) Simple $\mathrm{Hb} \mathrm{B}_{2}$ heterozygotes have nearly equal levels of $\mathrm{Hb} \mathrm{A}_{2}$ and $\mathrm{Hb} \mathrm{B}$, indicating that the $6 \times$ substitution at codon 16 of the $\delta$ gene (Gly)Arg in the $S$ chain) does not effect the relative synthesis of this variant chain, and thus, the presence of this $\delta$ gene marker offers an opportunity to study the relative formation of $\mathrm{Hb} \mathrm{A}_{2}$ derived from $\delta$ chains in cis or in trans to a $\$$-thal mutation. The one child of Family $M$ with $\mathrm{Hb} \mathrm{B}_{2}$ and $\mathrm{HbS}$ heterozygosities also had closely similar $\mathrm{Hb} \mathrm{A}_{2}$ and $\mathrm{Hb} \mathrm{B}_{2}$ values. 2) The nearly equal values for $\mathrm{Hb}_{2}$ and $\mathrm{Hb} \mathrm{B}_{2}$ in Family $K$ with the frameshift at codon $47(+A)$ confirm earlier data $(7)$ and suggest that mutations within the $\beta$-globin gene do not influence the relative synthesis of $\delta$ chains derived from $\delta$ genes in cis or in trans to the $\beta-$ thal

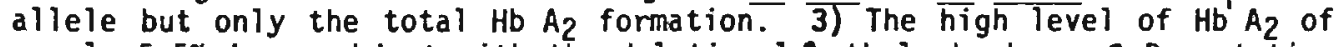
nearly $5.5 \%$ in a subject with the deletional $\beta$-thal who has a $\delta-B_{2}$ mutation in trans and a $\mathrm{Hb} \mathrm{B} \mathrm{B}_{2}$ level of $2.5 \%$, indicates that the excess $\mathrm{Hb}_{2}$ is derived from $\delta$ chains in cis to the $\beta$-thal deletion. 4) The high level of $\mathrm{Hb} \mathrm{A}_{2}$ (nearly 4.5\%) in a patient who had the -88 ( $\mathrm{C}-7$ ) mutation and the $\mathrm{Hb} \mathrm{B}_{2}$ mutation in trans (the $\mathrm{Hb} \mathrm{B}_{2}$ value was $2.5 \%$ ) showed that this mutation 
in the CACC box of the 5 ' $B$ promoter increases $H D A_{2}$ formation from $\delta$ chains in cis to this $\beta$-thal mutation. There are considerable differences between the $\mathrm{Hb} A_{2}$ and $\mathrm{Hb} B_{2}$ percentages found for this person; in 1963 at the age of 11 years, the values were $\mathrm{Hb} \mathrm{A}_{2} 2.70 \%$ and $\mathrm{Hb} \mathrm{B} \mathrm{B}_{2} 1.80 \%$, and in 1990 at the age of 39 years, the average $\mathrm{Hb} A_{2}$ and $\mathrm{Hb} \mathrm{B}_{2}$ values by DEAE-cellulose chromatography were 4.57 and $2.32 \%$, respectively. The considerably lower values found in the earlier study might be due to a coexisting iron deficiency, although this possibility was not evaluated at that time. These data suggest that at least two mechanisms can be responsible for higher levels of $\mathrm{Hb} \mathrm{A}_{2}$ in $\beta$-thal heterozygotes. One general mechanism concerns the relative excess of $\alpha$ chains in $\beta$ chain deficiencies which is present in all types of $\beta$-thal, albeit at different levels, dependent upon the type of $\beta$-thal. The second mechanism appears to be loss of $\beta$-globin gene promoter activity. Popovich et al (12) were the first to suggest that the transcription of the $\delta$-globin gene is affected by loss of the 5 ' $\beta$ promoter, perhaps because the $5^{\prime} \beta$ and $5^{\prime} 8$ promoters are influenced by the same $3^{\prime} \beta$ enhancer. The data presented here support this hypothesis and suggest that a mutation in the proximal CACC has a nearly similar effect as the loss of the entire 5 ' $\beta$ promoter. It may be that the loss of (or decreased) binding of a specific protein or a complex of proteins to this segment of DNA results in a decrease in or absence of BmRNA formation, and indirectly, in an increase in SmRNA formation because protein binding at the CACC box of the 5 ' $\delta$ promoter is not affected. Such a difference would not exist when the $\beta$-thal mutation is outside this promoter region, and the formation of 8 mRNA (although ineffective) is not influenced by this mutation. Another mechanism explaining the high $\delta$ chain production is that the deletion of the $\beta$-globin gene promoter or the mutations in the TATA $[-29(A>6)]$ or CACC $[-88(C \rightarrow T)]$ boxes (partially) removes competition for limiting transcription factors, which makes these more readily available to the $S$-globin gene promoter. However, this would effect equally the promoters of both $\delta$-globin genes and not only the $\delta$-globin gene in cis to the thalassaemia allele.

\section{ACKNOWLEDGEMENTS .}

This research was supported by the United States Public Health Service research grants $\mathrm{HLB}-05168$ and $\mathrm{HLB}-41544$. The authors are indebted to $\mathrm{Dr}$. K. Punt (Utrecht, The Netherlands), Dr. F. Bueno de Mesquita, Dr. J.D.G. Schaad, and to Mrs. T. Mercuur (Paramaribo, Surinam) for their help in obtaining some of the blood samples. This is contribution 1226 from the Department of Cell and Molecular Biology at the Medical College of Georgia in Augusta, Georgia.

\section{REFERENCES}

1. Kunkel, H.G., Ceppellini, R., Mueller-Eberhard, V., and Wolf, J.: Observations on the minor basic hemoglobin component in the blood of normal individuals and patients with thalassemia. J. Clin. Invest., $36: 1615,1957$.

2. Kutlar, A., Kutlar, F., Gu, L-G., Mayson, S.M., and Huisman, T.H.J.: Fetal hemoglobin in normal adults and $\beta$-thalassemia heterozygotes. Hum. Genet., 85:106, 1990. 
3. Jankovic, L., Efremov, G.D., Petkov, G.T., Kattamis, C., George, E., Yang, K-G., Stoming, T.A., and Huisman, T.H.J.: Two novel polyadenylation mutations leading to $\beta^{+}$-thalassaemia. Br. J. Haematol., 75:122, 1990.

4. Gonzalez-Redondo, J.M., Stoming, T.A., Kutlar, A., Kutlar, F., Lanclos, K.D., Howard, E.F., Fei, Y.J., Aksoy, M., Altay, F., Gurgey, A., Basak, A.N., Efremov, G.D., Petkor, G., and Huisman, T.H.J.: A C $\rightarrow$ T mutation at $n t-101$ in a conserved DNA sequence of the promoter region of the $\beta$-globin gene is associated with "silent" $\beta$-thalassemia. Blood, 73: $7705,1989$.

5. Bunn, H.F. and Forget, B.G.: Hemoglobin: Molecular, Genetic and Clinical Aspects, W.B. Saunders Company, Philade

6. Gonzalez-Redondo, J.M., Stoming, T.A., Lanclos, K.D., Gu, Y.C., Kutlar, A., Kutlar, F., Nakatsuji, T., Deng, B., Han, I.S., McKie, V.C., and Huismam, T.H.J.: Clinical and genetic heterogeneity in Black patients with homozygous $B$-thalassemia from the Southeastern United States. Blood, 72:1007, 1988 .

7. Huisman, T.H.J., Punt, K., and Schaad, J.D.G.: Thalassemia minor associated with Hemoglobin-B2 heterozygosity. A family report. Blood, $17: 747,1961$.

8. Lee, R.C. and Huisman, T.H.J.: Study of a family possessing Hemoglobin $C$, classical thalassemia and the abnormal minor hemoglobin component $A_{2}{ }^{\prime}$. Am. J. Hum. Genet., 15:69, 1963.

9. Salkie, M.L., Gordon, P.A., Rigal, W.M., Lam, H., Wilson, J.B., Headlee, M.E., and Huisman, T.H.J.: Hb A2-Canada or $\alpha_{282}$ 99(G1) Asp-sAsn, a newly discovered delta chain variant with increased oxygen affinity occurring in cis to $\beta$-thalassemia. Hemoglobin, $6: 223,1982$.

10. Padanilam, B.J., Fefice, A.E., and Huisman, T.H.J.: Partial deletion of the $5^{\prime} \beta-g$ lobin gene region causes thalassemia in members of an American Black family. Blood, 64:941, 1984 .

11. Diaz-Chico, J.C., Yang, K.G., Kutlar, A., Reese, A.L., Aksoy, M., and Huisman, T.H.J.: An $\sim 300$ bp deletion involving part of the $5^{\prime} \beta$-globin gene region is observed in members of a Turkish family with $\beta$-thalassemia. Blood, 70:583, 1987.

12. Popovich, B.W., Rosenblatt, D.S., Kendall, A.G., and Nishioka, Y.: Molecular characterization of an atypical $\beta$-thalassemia caused by a large deletion in the $5^{\prime} \beta$-globin gene region. Am. J. Hum. Genet., $39: 797,1986$.

13. Gonzalez-Redondo, J.M., Kattamis, C., and Huisman, T.H.J.: Characterization of three types of $\beta^{\circ}$-thalassemia resulting from a partial deletion of the $\beta$-globin gene. Hemoglobin, 13:377, 1989.

14. Thein, S.L.. Hesketh, C., Brown, J.M., Anstey, A.V., and Weatherall, D.J.: Molecular characterization of a high $\mathrm{Hb} \mathrm{A}_{2} \mathrm{\beta}$-thalassemia by direct sequencing of single strand enriched amplified genomic DNA. Blood, 73:924, 1989.

15. Bisse, E. and Wieland, H.: High-performance liquid chromatographic separation of human haemoglobins - Simultaneous quantitation of foetal and glycated haemoglobins. J. Chromatogr., 434:95, 1988.

16. Schroeder, W.A. and Huisman, T.H.J.: The Chromatography of Hemoglobin, Clinical and Biochemical Analysis, Vol. 9, Marcel Dekker, Inc., New York, 1980.

17. Poncz, M., Solowiejczyk, D., Harpe1, B., Mory, Y., Schwartz, E., and Surrey, S.: Construction of human gene libraries from small amounts of peripheral blood: Analysis of $\beta^{-l i k e}$ globin genes. Hemoglobin, $6: 27,1982$. 
18. Codrington, J.F., Kutlar, F., Harris, H.F., Wilson, J.B., Stoming, T.A., and Huisman, T.H.J.: Hb A2-Wrens or $\alpha \hat{2} 2^{98}$ (FG5)Val-XMet, an unstable $\delta$ chain variant identified by sequence analysis of amplified DNA. Biochim. Biophys. Acta, 1009:87, 1989. 
CHAPTER 4d

HB E- $\beta$-THALASSAEMIA IN SURINAM 


\section{ABSTRACT}

During our survey for haemoglobinopathies in the Surinam population, six families were observed with $H b E-B$-thal. A detailed comparison was made of the clinical condition, haematological data, $H b$ composition, and types of 3 -thal alleles present in these Suriman E-B-thal patients and with those of 28 patients from Malaysia, China, and Georgia (USA). The majority of the 28 patients were attending a haematology clinic in Kuala Lumpur (Malaysia), five were from the southern part of China, and the one patient (D.D.) from Georgia was of mixed Korean-Italian descent. All patients from Surinam with the E-B-thal condition were descendants of immigrants from Indonesia or India. A total of 54 chromosomes from 27 individuals were analyzed, mainly by hybridization with specific oligonucleotide probes after DNA amplification. Six different $\beta$-thal mutations, including the $\beta E$ mutation, were detected in the six Suriman families; also detected was a rare splice junction mutation, IVS-I-2 (T-C), which was previously found in an American Black teenager and an Algerian child.

\section{INTRODUCTION}

$2.1 \mathrm{Hb} E$ or $326(B 8) G 1 u<L y s$, has an amino acid substitution caused by a $\rightarrow$ A mutation in codon (CD) 26 of the B-globin gene, and is probabiy one of the most prevalent genetic traits in man (1). The inheritance of the $\mathrm{B}_{-g l o b i n}$ gene is associated with hypochromia and microcytosis which is already evident for the simple $H b E$ heterozygote. Hb $E$ homozygotes are slightly anaemic with a haematology resembling that of a classical $\beta$-thal heterozygosity with low MCV ( $<70 \mathrm{fl}$ ) and low. MCH values ( $<20 \mathrm{pg})$, target cells, and an increased resistance to osmotic lysis (2-4). The synthesis of $\mathrm{B}^{\mathrm{E}}$ chains in reticulocytes is impaired, and values of 1.2 to 2.1 have beeh reported for the $\alpha / \beta$ in vitro chain synthesis ratio in $H b E$ homozygotes who do not have an associated $\alpha$-thal $(5,6)$. Older studies suggested that the altered ratio could be due to an increased instability of the $\beta E$ chain (5). However, more recent investigations have shown that the decreased ${ }^{E}$ synthesis is associated with reductions in levels of $\$-g l o b i n$ mRNA comparable to those observed for $\beta$-thal trait (6-8). The 6-A mutation in CD 26 at the $3^{\prime}$ end of the first exon results in the activation of an alternate splice site, in the formation of an abnormally spliced mRNA, and an instability of the mRNA during erythroid maturation (1). Hb E is commonly observed among the populations of Far Eastern countries such as Thafland, Vietnam, Cambodia, Laos, Malaysia, Indonesia, South China, the Philippines, and India, with frequencies up to $54 \%$ in some areas of Southeast Asia. It is also found among Southeast Asian immigrants who have been relocated in various western countries $(2,3,9)$, including Surinam (10-13).

$2.2 \mathrm{Hb} E-\beta$-Thal. The frequency for $\beta$-thal varies from 3 to $9 \%$ in the populations of Far Eastern countries and, thus, the occurrence of a compound heterozygosity with $\mathrm{Hb} \mathrm{E}$ is high in these populations. Interaction 
of the $\beta^{E}-g l o b i n$ gene (which behaves as a mild $\beta$-thal gene) with a $\beta^{+}$- or $\beta^{\circ}$-thal gene often results in a severe clinical condition with a profound haemolytic anaemia, splenomegaly, and in some cases growth retardation. The severe cases are completely transfusion-dependent. This condition is common among Southeast Asians because of the relatively high frequencies of different $\beta^{\circ}$-thal alleles $(14-18)$. It is somewhat difficult to understand why $H b E-\beta$-thal is often such a severe condition; the relatively modest $\beta$ chain deficit observed in $H b E$ heterozygotes and homozygotes would suggest that the combination of $\mathrm{Hb} E$ with a $\hat{\beta}$-thal would lead to a thalassaemia intermedia rather than a thalassaemia major. Perhaps the relative excess of $\alpha$ chain in $H b E-\beta$-thal provides an oxidative stress that will enhance the denaturation of $H b E$ and the haemolysis of red cells containing this denatured protein (1). Alleviation of the condition may occur if $\mathrm{Hb} E$ - $\beta$-thal is combined with $\alpha$-thal (19). As stated before, numerous mutations leading to $\beta$-thal conditions have been discovered in the Southeast Asian populations, the most frequently occurring mutations are listed in Table 4d.1. Frameshifts or nonsense mutations such as those at $\operatorname{CDs} 8 / 9$ $(+6), \operatorname{CD} 35(-C), \operatorname{CDs} 41 / 42(-\pi T C T), \operatorname{CDs} 71 / 72(+A), \operatorname{CD} 15(G>A)$, and $\operatorname{CD} 17$ $(A, T)$, lead to a severe $\beta^{\circ}$-thal. The same is the case for the mutation at IVS-I-1 (Gत्र) which prevents proper processing of RNA, the C $\rightarrow$ mutation at IVS-II-654, and for the deletional $\beta^{\circ}$-thal allele $(619 \mathrm{bp})$ observed at a

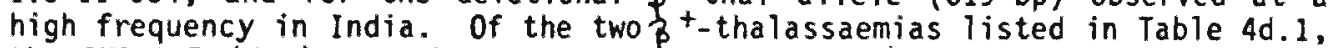
the IVS-1-5 (G) mutation is a severe type of $\beta^{+}$-thal with only a modest amount of 3 chains being synthesized in the homozygote (3-6\% of the total $\mathrm{Hb}$ ), while the transcriptional mutant at $\mathrm{nt}-28(A>6)$ of the $\beta-g$ lobin gene promoter, is one of the many milder types of $\beta^{+}$-thal. While reviewing these various $\beta$-thal alleles, it will become evident that most patients with $\mathrm{Hb} E-\beta$-thal will have a severe disease.

TABLE 4d.1 The Most Frequently Occurring $\beta$-Thal Alleles in Some Southeast Asian Populations

\begin{tabular}{|c|c|c|c|c|}
\hline India & Thailland & China & Malaysia & Indonesia \\
\hline $\begin{array}{l}\text { IVS-I-5 } \\
\text { (G)C) }\end{array}$ & $\begin{array}{l}\text { CDs } 41 / 42 \\
(-\pi T C)\end{array}$ & $\begin{array}{l}\text { CDs } 41 / 42 \\
\text { (-TTCT) }\end{array}$ & $\begin{array}{l}\text { IVS-I-5 } \\
(6 \times C)\end{array}$ & $\begin{array}{l}\text { IVS-I-5 } \\
(G \times C)\end{array}$ \\
\hline $\begin{array}{l}\text { Deletion } \\
(-619 \text { bp })\end{array}$ & $\begin{array}{l}C D 17 \\
(A \rightarrow T)\end{array}$ & $\begin{array}{l}C D 17 \\
(A \rightarrow T)\end{array}$ & $\begin{array}{l}\cos 41 / 42 \\
\text { (-TCT) }\end{array}$ & $\begin{array}{l}\text { IVS-II-654 } \\
(C \rightarrow T)\end{array}$ \\
\hline $\begin{array}{l}\operatorname{CDs} 8 / 9 \\
(+6)\end{array}$ & $\begin{array}{l}\text { IVS-II-654 } \\
(C \rightarrow T)\end{array}$ & $\begin{array}{l}-28 \\
(A>6)\end{array}$ & $\begin{array}{l}\text { IVS-I - I } \\
(G \rightarrow T)\end{array}$ & $\begin{array}{l}\text { IVS-I-1 } \\
\text { (6-T) }\end{array}$ \\
\hline $\begin{array}{l}\text { IVS-I-1 } \\
\text { (G)T) }\end{array}$ & $\begin{array}{l}\text { IYS-I-1 } \\
(G>C)\end{array}$ & $\begin{array}{l}\text { IVS-I1-654 } \\
\text { (C)T })\end{array}$ & $\begin{array}{l}\text { IVS-II-654 } \\
\left(C_{>} T\right)\end{array}$ & $\begin{array}{l}C D 15 \\
(G \rightarrow A)\end{array}$ \\
\hline $\begin{array}{l}\text { CDs } 41 / 42 \\
\text { (-TCT) }\end{array}$ & & $\begin{array}{l}\operatorname{Cos} 71 / 72 \\
(+A)\end{array}$ & $\begin{array}{l}C D 35 \\
(-C)\end{array}$ & $\begin{array}{l}C D 35 \\
(-C)\end{array}$ \\
\hline
\end{tabular}

The transcriptional mutant -28 ( $A>6)$ and the IVS-I-5 (G;C) consensus sequence mutation cause a $\beta^{+}$-thal; all others result in a $\beta^{\circ}$-thal. The listing is based on frequencies; the allele with the highest frequency is listed first. 


\section{PATIENTS AND METHODS}

3.1 Patients. With the help of the local physicians and laboratory technicians in Surinam, blood samples from members of six families were collected. At least one member of each of these families had the $H b E-\beta$ thal disease. Most of these compound heterozygote patients were given regular transfusions. The diagnosis of $\beta$-thal and of $H \mathrm{~B} E$ - $\beta$-thal was established by clinical and haematological examination, and by cellulose acetate electrophoresis in the Academisch Ziekenhuis in Paramaribo (Surinam). When possible, the blood of those transfusion-dependent patients was collected prior to transfusion. Collection was in vacutainers with EDTA as anticoagulant. The samples were stored at $+4^{\circ} \mathrm{C}$ and shipped by air to Augusta, GA (USA) within one week of collection.

3.2 Haematological Procedures. Haematological data were obtained with an automated cell counter. Red cell lysates were studied by IEF and by cation exchange HPLC (20). Since $H b E$ and $H b A_{2}$ are difficult to separate with this procedure, an estimate of the $H b A_{2}$ values was determined (as $\% \delta$ ) by reversed phase $\operatorname{HPLC}(21,22)$ (Fig. $4 d .1$ ). The level of $\mathrm{Hb} F$ was estimated with an alkali denaturation procedure as described in Chapter 2. The composition of the $H b F$ was determined by reversed phase $\operatorname{HPLC}(21,22)$.
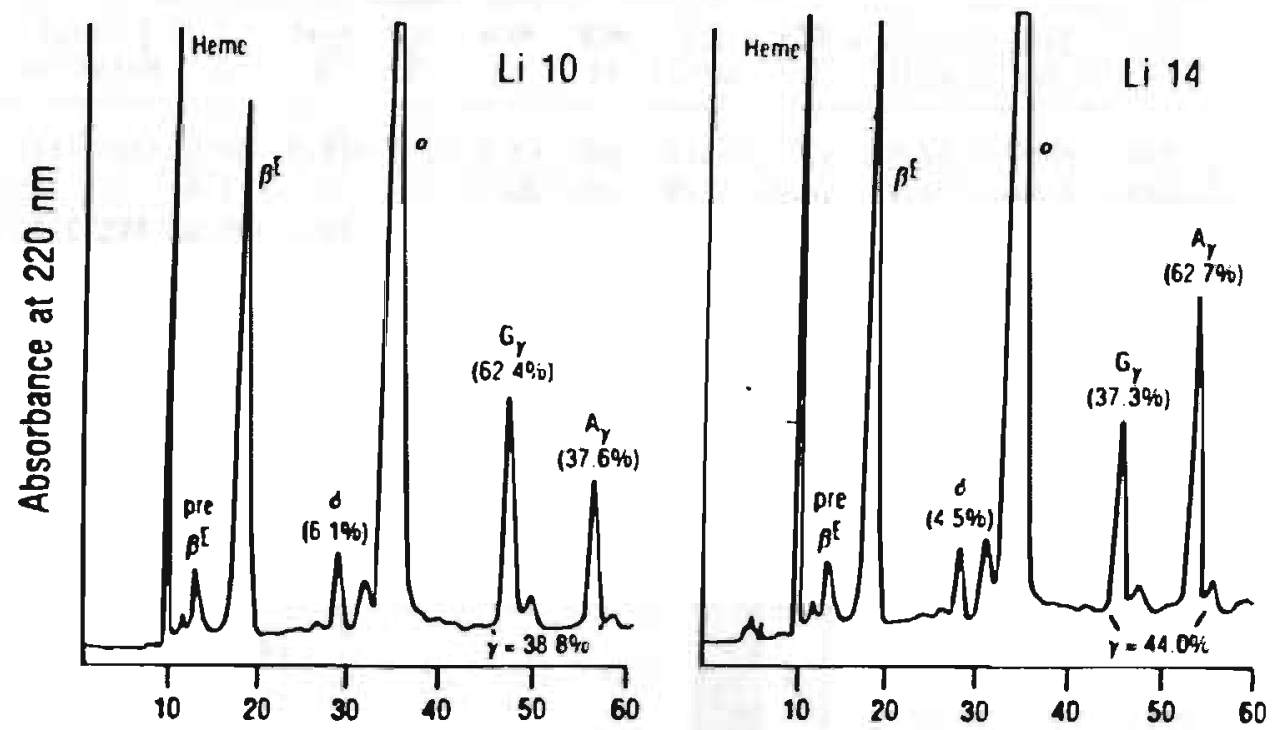

Time in Minutes $(1 \mathrm{ml} / \mathrm{min})$

FIG. 4d.1 Separation of the $\beta E, \delta, \alpha$, and $\gamma$ chains in red cell lysates from two Chinese patients with $H b E-\beta^{\circ}$-thal by reversed phase HPLC. The separation of the $\beta^{E}, \delta$, and $\alpha$ chains was complete. See Refs. 21 and 22 for technical details.

3.3 Analysis of $\alpha$-6lobin Genes. The numbers of $\alpha-g$ lobin genes and possible abnormalities in the $z_{-g}$ obin gene arrangement were determined 
in DNA digests using the restriction enzymes Bam HI and Bgl II; hybridization was with $\alpha$ and $z$ probes $(23,24)$.

3.4 Characterization of B-Thal Mutations. In vitro DNA amplification was performed according to a modified method (described in chapter 2). Amplified DNA was applied to nitrocellulose filters as dots and hybridized with the appropriate oligonucleotide probes. For sequencing experiments, the amplification procedure was adjusted so that single strand DNA was obtained during the amplification process (Chapter 2).

\section{RESULTS}

4.1 Family $1(S-448, S-449, S-450)$. The propositus in this family is a 4-year-old boy who receives regular transfusions. Both parents are of Javanese descent. The IEF data showed that the mother is a $\mathrm{Hb} E$ heterozygote. The father has the typical characteristics of a $\$$-thal heterozygote, namely microcytosis and an elevated $H b A_{2}$ value of $5.6 \%$ (Table $4 d .2$ ). Dot-blot analysis revealed an IVS-I-5 (G>C) mutation for both the father and the propositus.

TABLE 4d.2 Family 1; Haematological and Hb Composition Data; Pedigree

\begin{tabular}{|c|c|c|c|c|c|c|c|c|c|c|c|}
\hline Case & $\begin{array}{l}\text { Sex- } \\
\text { Age }\end{array}$ & $\begin{array}{c}\mathrm{Hb} \\
\mathrm{g} / \mathrm{dl}\end{array}$ & $\begin{array}{l}\text { PCV } \\
1 / 1\end{array}$ & $\begin{array}{c}R B C \\
10^{12 / 1}\end{array}$ & $\begin{array}{c}\mathrm{MCV} \\
\mathrm{fl}\end{array}$ & $\begin{array}{c}\mathrm{MCH} \\
\mathrm{pg}\end{array}$ & $\mathrm{A}_{2}$ & $\underset{\%}{A_{2}+E}$ & $\begin{array}{l}F \\
\alpha\end{array}$ & $\begin{array}{l}\beta \text {-Thal } \\
\text { Mutation }\end{array}$ & $\stackrel{\star \alpha}{\text { Genes }}$ \\
\hline$S-448$ & $M-26$ & 13.6 & .550 & 5.52 & 100 & 24.6 & 5.6 & 29.4 & $<1.0$ & $1 / \Delta-I-5$ & 4 \\
\hline$S-449$ & $F-24$ & 10.7 & .435 & 5.29 & 82 & 20.2 & & - & 1.6 & & 4 \\
\hline$S-450$ & H- 4 & 8.0 & .310 & 3.31 & 94 & 24.2 & 4.2 & 16.9 & 21.6 & IVS-I-5 & 4 \\
\hline
\end{tabular}

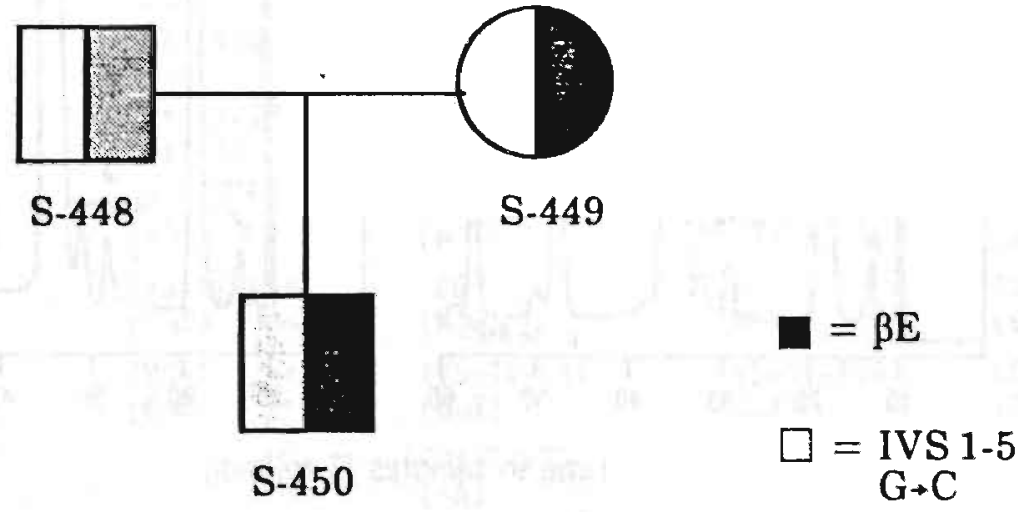

4.2 Family 2 (S-497, S-498, S-555). This is the only family of AsianIndian (Hindustani) descent in this study. The propositus $\mathbf{S - 5 5 5}$ is a 6 year-old female who is regularly transfused. Dot-blot analysis showed that the father and the propositus have the CDs 41/42 (-TTCT) frameshift mutation. Haematological data are given in Table 4d.3; the propositus and her parents have a normal $\alpha$-globin gene arrangement $(\alpha \alpha / \alpha \alpha)$. 
TABLE 4d.3 Family 2; Hacmatological and Hb Composition Data; Pedigree

\begin{tabular}{|c|c|c|c|c|c|c|c|c|c|c|c|}
\hline Case & $\begin{array}{l}\text { Sex- } \\
\text { Age }\end{array}$ & $\begin{array}{c}\mathrm{Hb} \\
\mathrm{g} / \mathrm{d} 1\end{array}$ & $\begin{array}{l}\text { PCY } \\
1 / 1\end{array}$ & $\begin{array}{c}\mathrm{RBC} \\
10^{12} / 1\end{array}$ & $\begin{array}{c}\mathrm{MCV} \\
\mathrm{fl}\end{array}$ & $\begin{array}{c}\mathrm{MCH} \\
\mathrm{pg}\end{array}$ & $\mathrm{A}_{2}$ & $\underset{*}{\mathrm{~A}_{2}+\mathrm{E}}$ & $\begin{array}{l}F \\
x\end{array}$ & $\begin{array}{l}\beta \text {-Thal } \\
\text { Mutation }\end{array}$ & $\begin{array}{c}\| \alpha \\
\text { Genes }\end{array}$ \\
\hline$S-497$ & $M-36$ & 11.3 & .46 & 6.04 & 76 & 18.7 & 5.9 & - & 2.8 & $\cos 41 / 42$ & 4 \\
\hline$S-498$ & $F-37$ & 11.8 & .47 & 4.94 & 95 & 23.9 & 5.4 & - & $<1.0$ & - & 4 \\
\hline$S-555$ & F- 6 & 5.5 & .24 & 2.70 & 89 & 20.4 & - & 29.1 & 31.1 & $\operatorname{CDs} 41 / 42$ & 4 \\
\hline
\end{tabular}

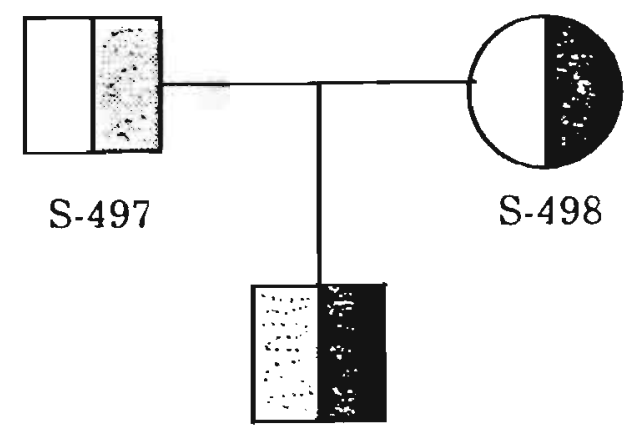

$$
\begin{aligned}
\square= & \beta E \\
\square= & \text { FSC } 41-42 \\
& (-\mathrm{TTCT})
\end{aligned}
$$$$
\text { S-555 }
$$

4.3 Family $3(S-456, S-457, S-458, S-459)$. This family is also of Javanese origin. IEF and cation exchange HPLC showed that the two children and their mother have $H b E$, while the father is a $\beta$-thal heterozygote with a $\mathrm{Hb} \mathrm{A} \mathrm{A}_{2}$ level of $5.9 \%$. Additional data including the numbers of $\alpha-g l o b i n$ genes in all four individuals are given in Table 4d.4. Sequencing of amplified DNA from one of the children showed that the $\beta$-thal in this family is due to a frameshift at $\operatorname{CDs} 8 / 9(+6)$. This result was confirmed by dot-blot hybridization experiments. Clinically, there were some differences between the two children. The daughter $(S-458)$ has been transfused almost every four months, while the son $(S-459)$ has not received any transfusions thus far. This difference is likely the result of a mild $\alpha$ chain deficiency in the son $\left(-\alpha^{3.7}\right)$ reducing the relative imbalance between $\alpha /$ non- $\alpha$ chains.

\begin{tabular}{|c|c|c|c|c|c|c|c|c|c|c|c|}
\hline Case & $\begin{array}{l}\text { Sex- } \\
\text { Age }\end{array}$ & $\begin{array}{l}\mathrm{Hb} \\
\mathrm{g} / \mathrm{d} l\end{array}$ & $\begin{array}{l}\text { PCY } \\
1 / 1\end{array}$ & $\begin{array}{c}\text { RBC } \\
10^{12} / 1\end{array}$ & $\begin{array}{c}\text { MCV } \\
\text { f1 }\end{array}$ & $\begin{array}{l}\mathrm{MCH} \\
\mathrm{pg}\end{array}$ & ${ }^{A} 2$ & $\underset{x}{A_{2}+E}$ & $F$ & $\begin{array}{l}\beta \text {-Thal } \\
\text { Mutation }\end{array}$ & $\begin{array}{c}\| \alpha \\
\text { Genes }\end{array}$ \\
\hline$S-456$ & $M-32$ & 12.5 & .540 & 6.89 & 78 & 18.1 & 5.9 & - & $<1.0$ & $\cos 8 / 9$ & 4 \\
\hline$S-457$ & $F-28$ & 12.8 & .560 & 4.80 & 117 & 26.7 & - & 26.1 & $<1.0$ & - & 3 \\
\hline$S-458$ & $F-13$ & 5.9 & .260 & 3.57 & 73 & 16.5 & - & 11.9 & 25.7 & $\operatorname{CDs} 8 / 9$ & 4 \\
\hline S-459 & $M-9$ & 7.0 & .415 & 4.15 & 111 & 18.8 & - & 11.7 & 29.5 & $\cos 8 / 9$ & 3 \\
\hline
\end{tabular}

TABLE 4d.4 Family 3; Haematological and Hb Composition Data; Pedigree 
Table 4d.4 contínued: Pedigree

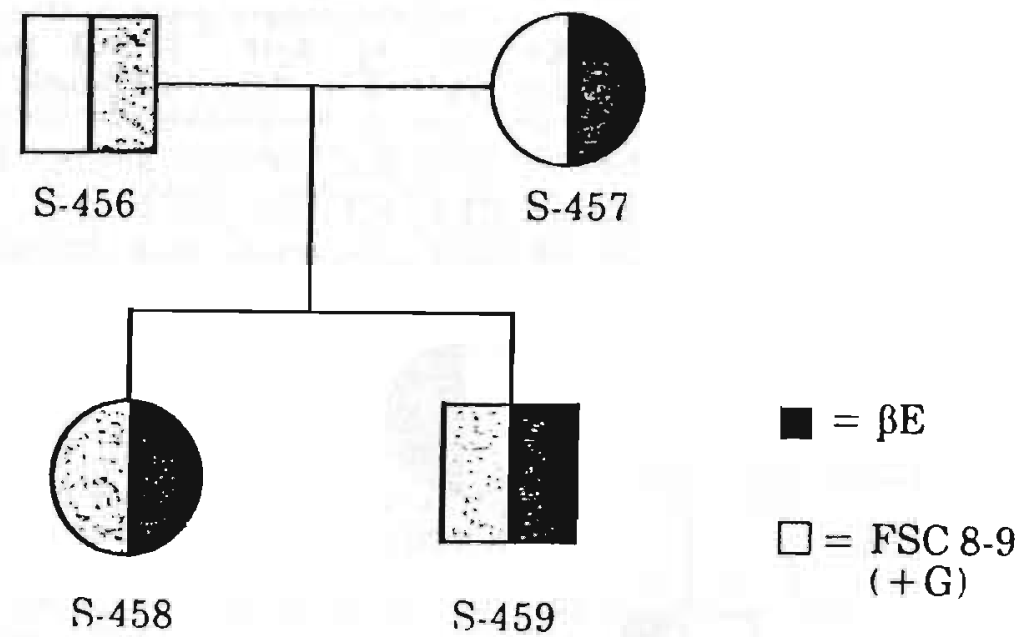

4.4 Families 4 (S-491-S-496) and 5 (S-504-S-507). Families 4 and 5 are also of Javanese descent. In Family 4 , the propositus is a 35-year-old female ( $(5-493)$ with three children. These three children are $\beta$-thal heterozygotes (see pedigree). The propositus has a history of severe anaemia and has taken iron for the last 15 years to treat the anaemic condition without success. She has developed a severe haemochromatos is leading to iron deposits in the liver, as was shown by liver biopsy. Dot-blot analys is indicated a frameshift at $C D 35(-\mathrm{C})$ in all $\beta$-thal carriers from both families. This thalassaemic gene was first described among Malay patients (16) and has also been observed in Indonesia (25). In Family 5, the daughter ( $S-506)$ receives blood transfusions on a regular basis (once a year), while the son (S-506), with a similar condition, has not yet been transfused. All members of Families 4 and 5 have a normal $\alpha$-globin gene arrangement $(\alpha \alpha / \alpha \alpha)$. Haematological data are listed in Table 4d.5.

TABLE 4d.5 Families 4 and 5; Haematological and Hb Composition Data; Pedigrees

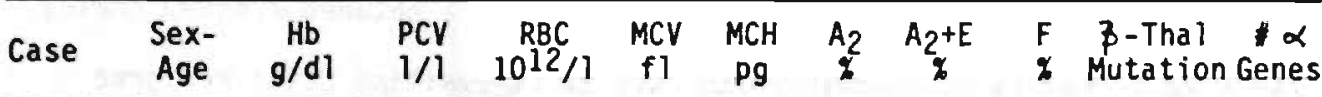

Family 4

\begin{tabular}{rrrrrrrrrrrr} 
S-490 & F-52 & 10.9 & .490 & 5.73 & 86 & 19.0 & 5.0 & - & 0.7 & CD 35 & 4 \\
S-491 & F-27 & 10.4 & .455 & 5.40 & 84 & 19.3 & 5.2 & - & 2.9 & CD 35 & 4 \\
S-492 & F-22 & 12.7 & .490 & 4.40 & 111 & 28.9 & 2.5 & - & $<1.0$ & - & 4 \\
S-493 & F-35 & 6.2 & .275 & 2.73 & 101 & 22.7 & - & 50.7 & 36.4 & CD 35 & 4 \\
S-494 & F-15 & 9.4 & .405 & 5.48 & 74 & 17.2 & 5.1 & - & 0.5 & CD 35 & 4 \\
S-495 & F-12 & 9.9 & .430 & 5.68 & 76 & 17.4 & 5.4 & - & 0.5 & CD 35 & 4 \\
S-496 & M- 6 & 9.3 & .390 & 5.33 & 73 & 17.4 & 6.3 & - & 0.9 & CD 35 & 4 \\
\hline
\end{tabular}


Table 4d.5 continued: Family 5; Pedigrees

\begin{tabular}{|c|c|c|c|c|c|c|c|c|c|}
\hline Case & $\begin{array}{l}\text { Sex- } \\
\text { Age }\end{array}$ & $\begin{array}{c}\mathrm{Hb} \\
\mathrm{g} / \mathrm{d}]\end{array}$ & $\begin{array}{l}P C V \\
1 / 1\end{array}$ & $\begin{array}{c}\text { RBC } \\
10^{12 / 1}\end{array}$ & $\begin{array}{c}\text { MCV } \\
\text { fl }\end{array}$ & $\begin{array}{c}\mathrm{MCH} \\
\mathrm{pg}\end{array}$ & ${ }_{8}^{A_{2}}$ & ${ }^{A_{2}}+\mathrm{E}$ & $\begin{array}{l}F \quad \beta \text {-Thal } \alpha \\
\text { \&utation Genes }\end{array}$ \\
\hline
\end{tabular}

Family 5

$\begin{array}{rrrrrrrrrrrr}\text { S-504 } & \text { M-52 } & 12.3 & .520 & 6.22 & 84 & 19.8 & 6.2 & - & 1.0 & \text { CD } 35 & 4 \\ \text { S-505 } & \text { F-51 } & 12.1 & .485 & 4.62 & 105 & 26.2 & 4.8 & - & 1.4 & - & 4 \\ \text { S-506 } & \text { M-18 } & 10.2 & .400 & 5.07 & 79 & 20.1 & - & - & 52.0 & \text { CD } 35 & 4 \\ \text { S-507 } & \text { F-21 } & 8.3 & .340 & 4.25 & 80 & 19.5 & - & 40.6 & 58.6 & \text { CD } 35 & 4\end{array}$

Pedigrce lamily 4

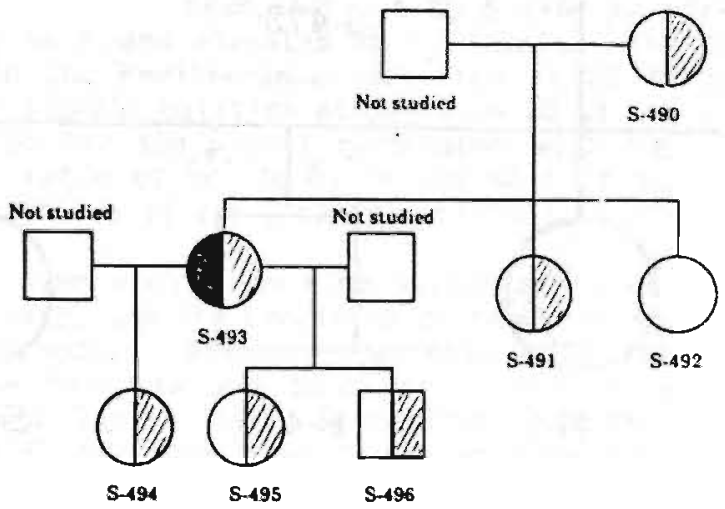

Pedigree family 5

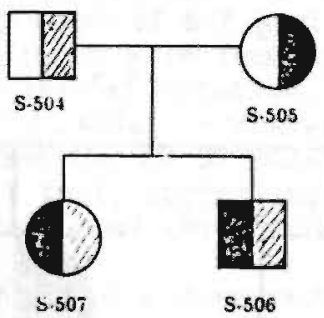

$=\beta E$
$0=\operatorname{Fsc} 3 s$

4.5 Family 6 (S-472-S-478). The propositus in this family is a 19year-old woman $(S-478)$, also of Javanese origin (see pedigree), who has the clinical characteristics of thalassaemia major such as growth retardation, bone malformation, severe anaemia, and a marked enlargement of liver and spleen. She has been transfused once every three weeks and has been hospitalized frequently. Her $\mathrm{Hb} \mathrm{F}$ level is a low $3.7 \%$ which can be explained by the frequent blood transfusions. Haematological data are listed in Table 4d.6. 
TABLE 4d.6 Family 6; Haematological and Hb Composition Data; Pedigree

\begin{tabular}{|c|c|c|c|c|c|c|c|c|c|c|c|}
\hline Case & $\begin{array}{l}\text { Sex- } \\
\text { Age }\end{array}$ & $\begin{array}{c}\mathrm{Hb} \\
\mathrm{g} / \mathrm{dl}\end{array}$ & $\begin{array}{l}\mathrm{PCV} \\
1 / 1\end{array}$ & $\begin{array}{c}\mathrm{RBC} \\
10^{12} / 1\end{array}$ & $\begin{array}{c}\mathrm{MCV} \\
\mathrm{fl}\end{array}$ & $\begin{array}{c}\mathrm{MCH} \\
\mathrm{pg}\end{array}$ & $\mathrm{A}_{2}$ & $F$ & $\mathrm{~A}_{2}+E$ & $\begin{array}{l}\beta \text {-Thal } \\
\text { Mutation }\end{array}$ & $\begin{array}{c}\| \alpha \\
\text { Genes }\end{array}$ \\
\hline$S-472$ & $M-49$ & 11.4 & .455 & 5.09 & 89 & 22.4 & 6.0 & 1.9 & & IVS-I-2 & 4 \\
\hline$S-473$ & $F-42$ & 10.6 & .425 & 4.51 & 94 & 23.5 & - & $<1.0$ & - & - & 4 \\
\hline$S-474$ & F-17 & 9.1 & .355 & 4.14 & 86 & 22.0 & 6.0 & 1.5 & - & IVS-I-2 & 4 \\
\hline$S-475$ & $M-23$ & 14.8 & .575 & 5.00 & 115 & 29.6 & 3.0 & $<1.0$ & - & - & 4 \\
\hline$S-476$ & $M-13$ & 13.3 & .435 & 4.48 & 97 & 29.7 & 3.1 & 1.4 & - & - & 4 \\
\hline$S-477$ & $F-11$ & 10.4 & .410 & 4.86 & 84 & 21.4 & 5.8 & 3.5 & - & IVS-I-2 & 4 \\
\hline$S-478$ & F-19 & - & - & - & - & - & - & 3.7 & - & IVS-I-2 & 24 \\
\hline
\end{tabular}
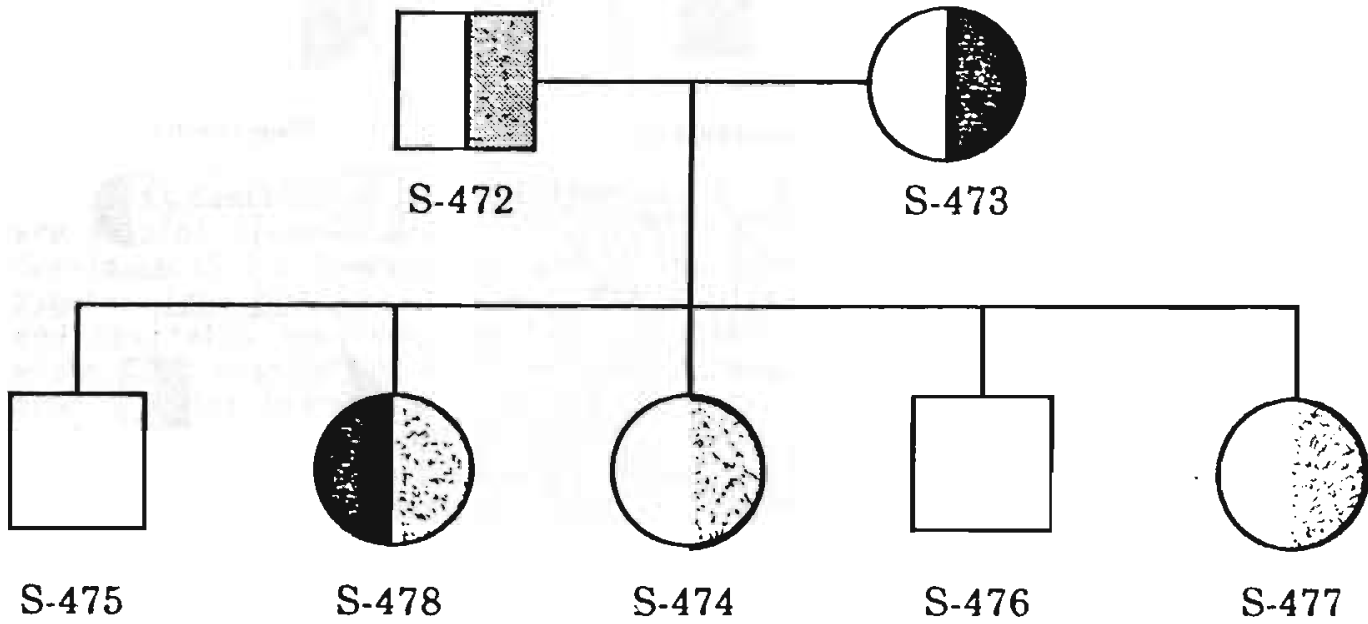

Sequencing of amplified DNA from the propositus showed a $\rightarrow C$ substitution at IVS-I-2. This rare mutation was first observed in 1988 in an American Black teenager who was a compound heterozygote for $\mathrm{Hb} S$ and the IVS-I-2 ( $\rightarrow C) \beta^{\circ}$-thal allele $(26)$. The clinical condition of the propositus $(S-478)$ and that of the American Black teenager were similar. A second case of the IVS-I-2 ( $A C$ C) mutation was reported in a child born to Algerian parents (27). This child was homozygous for this $\beta$-thal mutation. Splenectomy was performed at the age of nine and the child has not been transfused since then.

\section{DISCUSSION}

In addition to the Surinam $H b E-\beta$-thal patients, 28 patients from different countries were used to evaluate their clinical status, haematological data, $H b$ composition, and the types of $\beta$-thal alleles that were present (most of these data are from Ref. 28 and from personal communications). The results are listed in Table $4 \mathrm{~d} .7$. All 17 patients with $\mathrm{Hb}$ E- $\mathrm{B}$-thal (IVS-I-5; $\rightarrow$ C) were clinically severely affected; 11 were transfused at 
regular intervals. The haematological data for the six untransfused patients were as expected for this haenatological disease with severe microcytosis and hypochromia. The $\bar{P}$ haplotypes were determined in 12 patients; the three known types $(a, b, c)$ were present $(29,30)$. The $H b A_{2}$ levels were elevated but rather variable. The same can be stated for the $H b F$ values, while the $\beta^{A}$ chain synthesis varied between 3 and $6 \%$ only. The variation in the percentage of $H D F$ is most difficult to explain; the lowest level was seen in the patient with an $\alpha$-thal-2 heterozygosity. The level of $G_{\gamma}$ chains in the $H b F$ fell into two groups: 13 patients had high $G_{\gamma}$ (average 62.5\%) and four had low $G_{\gamma}$ (average 38/8\%), which seems to correlate with the haplotypes of the $\beta E$ chromosome (high Gyand haplotypes E-a and $E-c ; 10 w G_{\gamma}$ and haplotype $\left.E-b\right)$, suggesting that the synthesis of the $\gamma$ chain is primarily directed by the $\beta E$ chromosome.

Eleven patients 1 isted in Table $4 \mathrm{~d} .7$ had $\mathrm{Hb} E-\not B-t h a l$ and suffered from severe disease. Many were on a regular transfusion regimen. Three of the seven Chinese patients had the frameshift at CDs $41 / 42$ and four that of $\operatorname{CDs} 71 / 72$. Hb F levels were between 28 and $44 \%$ with the exception of patient $\mathrm{Li} 11$ who had only $10 \% \mathrm{Hb} F$ and a very high $\mathrm{Hb} \mathrm{A}_{2}$ level of 10.6\%. The $G_{\gamma}$ values were variable. The two siblings (S-458 and $S-459$ ) from Surinam with the frameshift at $C D 8(+6)$ maintained a $\mathrm{Hb}$ level of $6-7 \mathrm{~g} / \mathrm{dl}$ with $30 \% \mathrm{Hb} \mathrm{F}$ and elevated $\mathrm{Hb} \mathrm{A}_{2}$ levels. The patient with $\mathrm{Hb} F$ in combination with the Mediterranean mutation at $C D 39$ ( $C \rightarrow T)$ had the ArT mutation, i.e. the Ile $\rightarrow$ Thr mutation at position 75 of the $\gamma$ chain (31), which is characteristic for the $\beta$-thal chromosome with haplotype II and the CD 39 mutation. The ratio of $A_{Y} T$ to $A_{Y}$ in the $H b F$ of this boy was 2 to 1 , suggesting that two-thirds of the $\gamma$ chain synthesis is directed by the $\beta$-thal chromosome.

The eight remaining patients 1 isted in Table $4 \mathrm{~d} .7$ had a more moderate disease, and the condition of three of them should be listed as thalassaemia intermedia. All five patients with the CD 35 (-C) frameshift, i.e. two from Malaysia and three from Surinam, were not transfusion-dependent although low Hb levels were often observed. The $\mathrm{Hb} F$ levels were high (average $50.1 \%$ ) with high Gy values (average $62 \%$ ) and low Hb E levels (average 43.2\%; average $\delta$ chain values were $6.7 \%$ ), and this is likely a major factor for the somewhat milder condition observed in these patients.

TABLE 4b.7 Haematological and Hb Composition Data for 36 Patients With Hb E-B-Thal

\begin{tabular}{|c|c|c|c|c|c|c|c|c|c|c|c|}
\hline Case & $\begin{array}{l}\text { Sex- } \\
\text { Age }\end{array}$ & $\begin{array}{c}\mathrm{Hb} \\
\mathrm{g} / \mathrm{d}]\end{array}$ & $\begin{array}{c}\text { MCV } \\
\text { fl }\end{array}$ & $\begin{array}{c}\mathrm{MCH} \\
\mathrm{pg}\end{array}$ & 8 & $\gamma$ & $\beta_{x}^{A}$ & $\beta_{x}^{E}$ & $G_{x}$ & Origin & $\begin{array}{c}\alpha \\
\text { Genes }\end{array}$ \\
\hline
\end{tabular}

E-8+-Tha1; IVS-I-5 (ax)

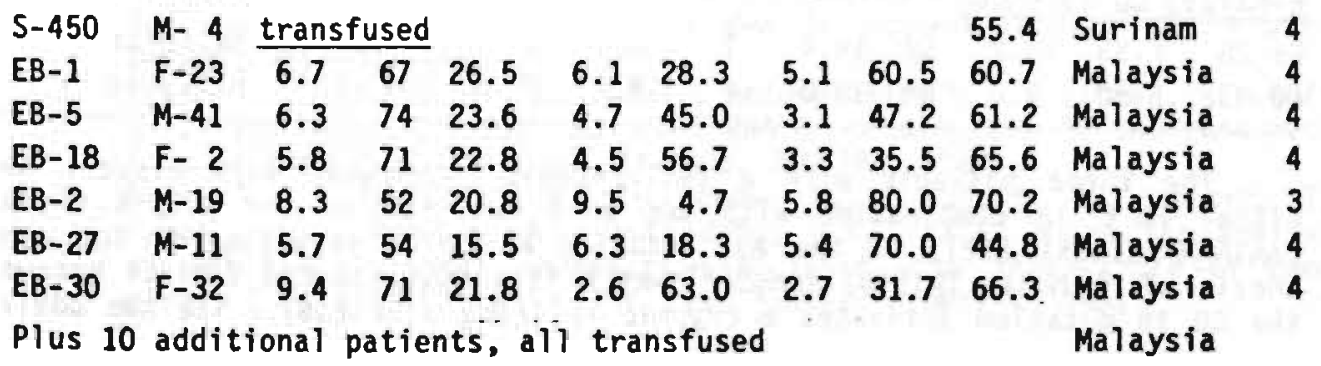


Table 4d.7 continued:

$\begin{array}{ccccccccccc}\text { Case } & \text { Sex- } & H b & M C V & M C H & \delta & \gamma & \beta_{A}^{A} & \beta^{E} & G \gamma & \\ & \text { Age } & g / d & f l & p g & \gamma & \gamma & \gamma & \gamma & \% & \text { Origin Genes }\end{array}$

E- $\beta^{\circ}-$ Thal; $\operatorname{CDs} 41 / 42$ (-TTCT)

\begin{tabular}{|c|c|c|c|c|c|c|c|c|c|c|c|}
\hline China 8 & $F-31$ & 6.8 & 63 & 17.0 & 5.5 & 32.9 & 0 & 61.6 & 56.0 & China & - \\
\hline Li 11 & $M-15$ & 4.8 & 74 & 16.4 & 10.6 & 9.8 & 0 & 79.6 & 31.2 & China & 4 \\
\hline$S-555$ & $F-6$ & trans & used & & & & & & 50.0 & Surinam & 4 \\
\hline
\end{tabular}

E- $\beta^{\circ}-$ Tha 1; $\operatorname{CDs~71/72(+A)}$

$\begin{array}{llllllllllll}\text { Li 7 } & \text { M-16 } & 8.9 & 56 & 16.8 & 6.9 & 27.0 & 0 & 65.4 & 66.9 & \text { China } & 4 \\ \text { Li } 10 & \text { M-12 } & 7.3 & 63 & 19.0 & 6.1 & 38.8 & 0 & 55.1 & 62.4 & \text { China } & 4 \\ \text { Li } 14 & \text { F-12 } & 7.5 & 85 & 23.1 & 4.5 & 44.0 & 0 & 50.5 & 37.3 & \text { China } & 4 \\ \text { Li } 27 & \text { F-14 } & 4.8 & 70 & 19.1 & 4.5 & 36.5 & 0 & 59.0 & 39.6 & \text { China } & 4\end{array}$

E- 7 -Tha $;$; CDs $8 / 9(+6)$

$\begin{array}{lllllllllll}\text { S-458 } & F-13 & 5.9 & 73 & 16.5 & 7.1 & 31.5 & 0 & 61.4 & 62.8 & \text { Surinam } 4\end{array}$

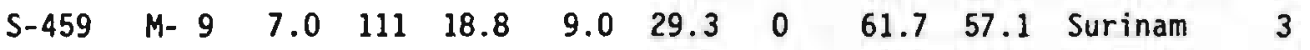

E- $\beta^{\circ}$-Tha I; IVS-I-2 (T>C)

S-478 F-19 transfused

Surinam 4

E- P $^{\circ}$-Tha 1; CD $39\left(C \rightarrow T^{\prime}\right)$
D.D. $\quad$ M- 9
$8.180 \quad 20.0$
$\begin{array}{lll}6.0 & 57.2 \quad 0\end{array}$
$36.8 \quad 59.0$ Georgia

E- קP-Thal; CD $35(-C)$

$\begin{array}{lrrrrrrrrrrr}\text { EB-7 } & \text { F-16 } & 7.1 & 80 & 22.0 & 4.4 & 48.7 & 0 & 47.9 & 69.2 & \text { Malaysia } & - \\ \text { EB-11 } & \text { M-11 } & 8.6 & 81 & 21.7 & 6.2 & 46.9 & 0 & 46.9 & 69.1 & \text { Malaysia } & - \\ \text { S-493 } & \text { F-35 } & 6.2 & 101 & 22.7 & 8.7 & 44.4 & 0 & 46.9 & 57.6 & \text { Surinam } & 4 \\ \text { S-506 } & \text { M-18 } & 10.2 & 79 & 20.1 & 8.8 & 51.9 & 0 & 39.3 & 58.6 & \text { Surinam } & 4 \\ \text { S-507 } & \text { F-21 } & 8.3 & 80 & 19.5 & 6.3 & 58.6 & 0 & 35.1 & 55.7 & \text { Surinam } & 4\end{array}$

\section{E-B ${ }^{+}$-Thal; Poly A (AATAAA>AATAGA)}
M.S.
M- 9
9.5
$59 \quad 18.6$
$\begin{array}{llll}4.3 & 7.6 & 41.6 & 46.5\end{array}$
- Malaysia

\section{E-Malay; CD 19 (A>G)}

$\begin{array}{lrrrrrrrrrr}\text { EB-28 } & F-55 & 10.2 & 58 & 19.4 & ? & 3.9 & 0 & - & 72.1 & \text { Malaysia - } \\ \text { EB-MB2 } & \text { F-50 } & 9.8 & 64 & 20.0 & ? & 9.7 & 0 & - & 66.2 & \text { Malaysia }\end{array}$

The three patients with a thalassaemia intermedia type disease had either $H b E$ in combination with the mild mutation in the poly $A$ signal (AATAAAPATAGA) (32), or the A>6 mutation at CD 19 resulting in the synthesis of $\mathrm{Hb}^{-}$Malay $[819(\mathrm{B1}) \mathrm{Asn}>\mathrm{Ser}]$ which is a thalassaemic variant because the CD 19 mutation dctivates a cryptic splicing site (16). The two adults 
with this condition had slightly elevated $H b F$ levels and no $H D A$, but the normally functioning $\mathrm{Hb}$ Malay was present in slight excess over $\mathrm{Hb} E$.

\section{CONCLUSION}

None of the Surinam Hb $E$ heterozygotes had an anemia or a severe microcytic condition. The individuals with $\mathrm{Hb} E-\beta$-thal were severely affected. The severity of the disease is determined by the type of $\beta$-thal allele that is present. Most $\beta$-thal mutations observed are nonsense mutations or frameshifts resulting in a total absence of normal $\beta^{A}$ mRNA production $\left(\beta^{\circ}-t h a 1\right)$, while one of the few $\beta^{+}$-thalassaemic alleles, namely the IVS-I-5 (GSC) mutation which occurs at high frequencies in Malaysia and Indonesia, causes a severe $\beta^{+}$-thalassaemic condition with only a modest $\beta^{A}$ production. It is interesting to note that two rare $\beta$-thal mutations, the IVS-I-2 ( $T \rightarrow C$ ) and the $\operatorname{CDs} 8 / 9(+6)$, occur in the Surinam-Javanese ethnic group; these two mutations have never before been reported for the Indonesian populations. Although the studied Javanese group is small, the heterogeneity of the \$-thal types seems to be tremendous in this ethnic group (five different types of $\beta$-thal in five families studied). An accurate diagnosis in all individuals with $\mathrm{Hb} E$ or $\mathrm{Hb} E-\beta$-thal at an early age may prevent long-term iron therapy in cases such as occurred in patient $5-493$. Pregnancies in women with $\mathrm{Hb}$ E- 8 -thal are associated with considerable maternal and foetal risk (33), so raising the awareness of this $\mathrm{Hb}$ disorder can contribute to an appropriate diagnosis and proper therapy. Couples at risk of having offspring with $\mathrm{Hb}$ E- $\beta$-thal should be considered for genetic counselling.

\section{REFERENCES}

1. Bunn, H.F. and Forget, B.G.: Hemoglobin: Molecular, Genetic and Clinical Aspects, W.B. Saunders Company, Philadelphia, 1986.

2. Fairbanks, V.F., Oliveros, R., Brandabur, J.H., Willis, R.R., and Fiester, R.F.: Homozygous Hemoglobin E mimics $\beta$-thalassemia minor without anemia or hemolysis: Hematologic, functional, and biosynthetic studies of first North American case. Am. J. Hematol. 8:109, 1980.

3. Hong, S.C. and Ali, M.A.M.: Hemoglobin E disease: Hematological, analytical, and biosynthetic studies in homozygotes and double heterozygotes for $\beta$-thalassemia. Am. J. Hematol., 13:15, 1982.

4. Lehmann, H., Story, P., and Thien, H.: Hemoglobin E in Burmese. Br. J. Med., 1:554, 1956.

5. Pagnier, J., Wajcman, H., and Labie, D.: Defects in hemoglobin synthesis possibly due to a disturbed association. FEBS Lett., 45:252, 1974.

6. Traeger, J., Wood, W.G., Clegg, J.B., Weatherall, D.J., and Wasi, P.: Defective synthesis of $\mathrm{Hb} E$ is due to reduced levels of $7 \mathrm{E}$ mRNA. Nature, 288:497, 1980 .

7. Orkin, S.H., Kazazian, H.H., Jr., Antonarakis, S.E., Ostrer, H., Goff, S.C., and Sexton, J.P.: Abnormal RNA processing due to the exon mutation of the $\beta E$ globin gene. Nature, $300: 768,1982$.

8. Benz, E.J., Berman, B.W., Tonkonow, B.L., Coupal, E., Coates, T., Boxer, L.A., Altman, A., and Adams, J.G., III: Molecular analysis of the $\beta$-thalassemia phenotype associated with inheritance of Hemo-

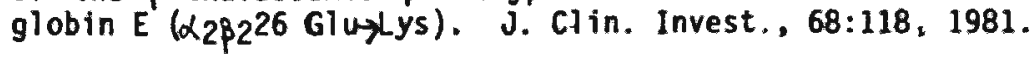




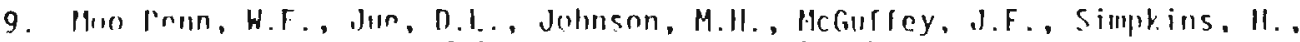
ancl Yat, J.: llemglobin fuerns: $N 34$ (B15) loning structural and funclioma properties and its association with Ilb E. Nm. J. IImatol., $13: 373,1987$.

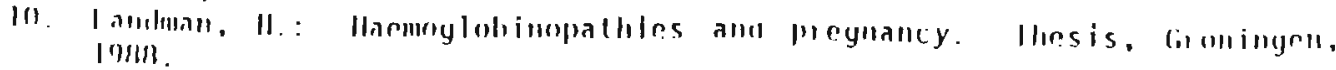

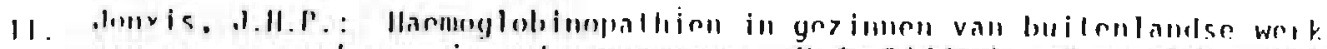

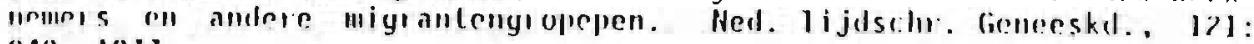
919, 1917.

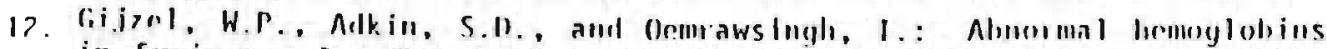
in Smininm. 1. Frequency among different elimic groups. Sm. Hird. IIIII., 19/8.

13. Codington, J.F., I., IIW., I iang. C.C., George, E., Kullar, F. and I luisman, T.H.J.: I mmoglobin Es Ilıalassemia.

Air. Jilnmalol (in press)

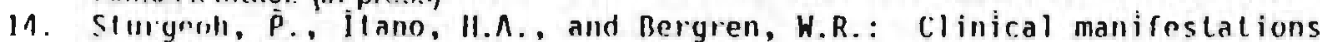
of inheriled abnormal linnoglobins. I1. Interaction of llemoglobin $E$ and lhalassemin trait. Blood, 10.396, 1955.

15. Hehta, B.C.. Agrawa 1, M.B., Varandan, D.G., JoshI, R.H., and Bhargava, A.B.: Ilemoglobin E thalassemia - $A$ study of 16 cases. Acta llaematol., (.1:201, 1980.

16. Yang, K.G., Kutlar, Г., George, F., Wilson, J.B., Kutlar, A., Stoming, J.A. Gomzalez-Redondlo, J.M., and Huisman, T.H.J.: Molecular characInrization of P-globin gene mutations in Malay patients with Ilb E-Pllanlassacmia and thalassaemla major. Br. J. Haenatol., 72:73, 1989.

17. Winichagoon, P., Kownkon, J., Yenchltsomanus, P., Thongla iroam, V., Sirltanaralkuk, N., and Fucharoen, S.: Detection of $\beta$-thalasscmia and llomolohin $E$ genes in Thal by a DNA amplification teclinique. Ilum. Connel., 82:389, 1989.

18. Ilulsman. T.ll.J.: Frequencies of conmon R-thalassaacmia alleles among different populations; variability in clinical severity. Br. J. HaemaInl., 76:154, 1990.

19. Winicliagoon, P., Fucharoen, S., Weatherall, D.J., and Wasi, P.: Concomilant inheritance of $\alpha$-thalassemia in $\beta$-thalassemia/llb $E$ disease. Am. I. Ilematol., 20:217, 1985.

70. K.utlar, A., Kutlar, F., Gu, L-G., Mayson, S.M., and lluisman, T.ll.J.: rnlal linmoglobin in normal adults and $\beta$-thalassemia heterozygotes. llum. Cinnel., 85:106, 1990.

21. Shollon, J.B., Shelton, J.R., and Schroeder, H.A.: Iligh performance liquid rhromatographic separation of globin chains on a large-pore Ci coltumm. J. Liq. Cliromalngr., 7:1969, 1984.

27. Kullar, F.. Kutlar, A., and lluisman, T.ll.J.: Scparation of normal and abmoimal hemoglobin chains by reversed-phase high-performance liquid cliromalography. J. Chromalogr., 357:117, 1986.

23. Telire, A.E., Cinnk. M.P., Marino, E.M., Mckie, K., Mckie, V.C., Chang. R.K.. and lluisman, T.ll.J.: Different 3 globin gene deletions among Black Americans. Hum. Genet., 73:22.1, 1986.

21. Fil, Y.C., I.anlminn, II., and lluisman, T.ll.J.: Two difference quadruplicalnd $\alpha$ globlin gene arrangements. Br. J. llacmatol., 66:245, 1987.

25. I. in.Injo, I.E., Cal, S-P.. Wahldljat, I., Moesliclian, S., Lim, M.I.., F.vangrlista. L.. Doherty, M., and Kan, Y.H.: B-Thalassemia mulations in luclonrsin and thelr linkage to $\beta$ liaplotypes. $\mathrm{Am}$. J. Ilum. Genet., $15: 971,1989$. 
26. Gonzalez-Redondo, J.M., Stoming, T.A., Kutlar, F., Kutlar, A., McKie, V.C., McKie, K.M., and Huisman, T.H.J.: Severe Hb S-F̄-thalassaemia with a $\rightarrow C$ substitution in the donor splice site of the first intron of the $\beta$-globin gene. Br. J. Haematol. , 71:113, 1989.

27. Lossi, A.M., Milland, M., Berge-Lefranc, J.L., Lena-Russo, D., and Perrimond, H.: A further case of $\$$-thalassemia with a homozygous $\mathrm{F} ; \mathrm{C}$ substitution at the donor splice site of the first intervening sequence of the p-globin gene. Hemoglobin, 13:619, 1989.

28. Sabio, H., Hu, H., Kutlar, F., Kutlar, A., and Huisman, T.H.J.: Interaction of $\mathrm{Hb} E$ with the $\mathrm{B}^{\circ}-39$ mutation. Blood, $72: 72 \mathrm{a}$ (Suppl. 1), 1988.

29. Antonarakis, S.E., Orkin, S.H., Kazazian, H.H., Jr., Goff, S.C., Boehm, C.D. , Waber, P.G., Sexton, J.P., Ostrer, H., Fairbanks, V.F., and Chakravarti, A.: Evidence for the multiple origins of the $\beta E_{-g}$ lobin gene in Southeast Asia. Proc. Natl. Acad. Sci. USA, 79:6608, 1982.

30. Kazazian, H.H., Jr., Waber, P.G., Boehm, C.D., Lee, J.I., Antonarakis, S.E., and Fairbanks, Y.F.: Hemoglobin E in Europeans: Further evi-

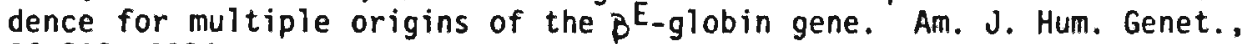
$36: 212,1984$.

31. Ricco, G., Mazza, U., Turi, R.M., Pich, P.G., Camaschella, C., Saglio, G., and Bernini, L.F.: Significance of a new type of human fetal hemoglobin carrying a replacement isoleucinesthreonine at position 75 (E19) of the $\gamma$ chain. Hum. Genet., 32:305, 1976.

32. Jankovic, L., Efremov, G.D., Petkov, G.T., Kattamis, C., George, E., Yang, K-G., Stoming, T.A., and Huisman, T.H.J.: Two novel polyadenylation mutations leading to $\beta^{+}$-thalassaemia. $\mathrm{Br}$. J. Haematol., 75:122, 1990.

33. Landman, H.: Haemoglobinopathies and pregnancy. Thesis, Groningen, 1988. 
CHAPTER 5

THE SURINAM $(\delta \beta)^{\circ}$-THALASSAEMIA IS DUE TO A DELETION OF $31.6 \mathrm{~KB}$ 


\section{ABSTRACT}

We describe a unique form of $\delta$-thal that has been observed in two generations of a Surinam family of Asian-Indian descent. The propositus is a 19-year-old female who received monthly blood transfusions. DNA from members of this family were studied through restriction enzyme analysis. Gene mapping studies showed no abnormal $\alpha$-globin gene rearrangements in any of the six family members. Studies on the $\beta$-globin gene locus using the $\beta$-IVS-II and pRK 28 probes, indicated the presence of an extensive deletion including the $\beta, \delta$, and $\psi \beta$ genes. The staraing polat of this deletion maps $1 \mathrm{~kb} 3^{\prime}$ to the $A \gamma$ gene, while the deletion ends approximately $10 \mathrm{~kb}$ $3^{\prime}$ to the $\bar{\beta}$ gene, just outside a region of repetitive sequences named $\mathrm{Kpn} 1$ or L1. The minimum size for this deletion is estimated to be $31.6 \mathrm{~kb}$. An IVS-I-5 (GC) mutation causing $\beta$-thal was present in the propositus, in trans of the $\delta \beta^{\circ}$ deletion. Rather high foetal Hb levels $(16-29 \%)$ were observed in the surinam $(\delta \beta)^{\circ}$ heterozygotes with a $\mathrm{G}$ : $A_{\gamma}$ ratio averaging $85: 15$.

\section{INTRODUCTION}

The molecular mechanism that control developmentally programed switches in gene expression have triggered the imagination of many molecular biologists. The developing human switches progressively from the embryonic Hbs $\left(3_{2} \varepsilon_{2}, \alpha_{2} \varepsilon_{2}\right.$, and $\left.3_{2} \gamma_{2}\right)$ to the fetal $H b\left(\alpha_{2} \gamma_{2}\right)$, and finally to the adult Hbs $\alpha_{2 B_{2}}$ and $\left.\alpha_{2} \varepsilon_{2}\right)$. In some individuals the switch is incomplete and the expresston of the $\gamma$ genes persists into adult life $(1,2)$. This condition is known as HPFH, or in some cases $\delta \beta$-thal (see Chapter 1). HPFH and\&Bthal are two phenotypically distinct syndromes that are associated with a total absence of 3 - and 8 -globin chain synthesis (2). They are often the result of large deletions of DNA in the $\beta-g l o b i n g e n e ~ c l u s t e r ~(3-5)$.

The level of $\gamma$ gene production is higher in deletional HPFH heterozygotes $(15-30 \%)$ than in $\delta \beta$-thal heterozygotes $(5-12 \%)$. Several $(\mathcal{\beta} \hat{p})^{\circ}$-thalassaemic chromosomes carry deletions that vary in length from 7.2 to $120 \mathrm{~kb}$ (2). This report describes a Surinam family with a G $A_{\gamma}(\delta \beta)^{\circ}-$ thal. The breakpoints were determined by restriction endonuclease mapping and by hybridization with specific probes.

\section{MATERIALS AND METHODS}

3.1 The Family. The propositus (II-4) is a 19-year-old female of Surinam-Asian descent who received monthly transfusions at the Academisch Ziekenhuis in Paramaribo, Surinam. She had an enlarged spleen and liver, growth retardation, and bone deformation. Blood samples were collected from the propositus and five of her relatives. The mother of the propositus had a history of multiple miscarriages. The living conditions of this uneducated family were extremely poor. 
3.2 Hacmatological and $\mathrm{Hb}$ Studies. Collection of blood, preparation of DNA, restriction endonuclease digestion of DNA, and gene mapping hybridization procedures have been described previously (Chapter 2). Red cell lysates were analyzed by IEF, and by reversed phase HPLC using a Vydac $C_{4}$ column (6). This procedure allows an accurate quantitation of the two types of $\gamma$ chain, $G_{\gamma}$ and $A_{\gamma}$, and the mutant $A_{\gamma}{ }^{\top}$ chain. Hb analyses included cation exchange HPLC for the quantitation of $\mathrm{Hb} \mathrm{A}_{2}(7,8)$ and alkali denaturation for the quantitation of $\mathrm{Hb} F(9)$.

\subsection{DHA Analysis.}

3.3a Dot-blot analysis. DNA samples from the propositus and her relatives were amplified using a primer set which allows amplification of an $\sim 700$ bp fragment that includes exon 1 , intron 1 , exon 2 , and a small segment $3^{\prime}$ to the second exon of $71 \mathrm{bp}$. The location of the primers is shown in chapter 2. Amplified DNA fragments were spotted onto a nylon membrane, baked at $80^{\circ} \mathrm{C}$ for 1 hour, and filters were hybridized with $32 p_{-}$ labelled probes, washed, and processed for autoradiography.

Leukocyte DNA was isolated from peripheral blood as described previously (Chapter 2). A $5 \mu \mathrm{g}$ aliquot of DNA was digested at $37^{\circ} \mathrm{C}$ with 20 units each of the following restriction endonucleases: Bam HI, Hind III, Eco RI, Xmn I, Xba I, Pst I, Bgl II, Hpa I, and Bcl I, using buffer conditions specified by the suppliers. DNA fragments were separated by electrophoresis in 0.8\% agarose gel, transferred to a nitrocellulose membrane, baked for 3 hours at $70^{\circ} \mathrm{C}$, and filters were hybridized with $32 \mathrm{p}-1$ abelled probes, washed, and processed for autoradiography. Hybridization was performed with the $\gamma$-IVS-II, $\varepsilon$-IVS-II, and pRK 28 probes, and with with $\alpha$ gene probes. Details about the probes are given elsewhere (Chapter 2).

\section{RESULTS}

The pedigree of the Surinam family is presented in Fig. 5.1 and haematological data are given in Table 5.1 (data for the propositus are not included because her blood sample was collected about three days after the last blood transfusion). HPLC studies shoed an increased $\mathrm{Hb} \mathrm{A}_{2}$ value for the mother of the propositus; her $\mathrm{MCH}$ value was decreased, while her $\mathrm{MCV}$ value was in the normal range. The normal MCV values is most likely due to inadequate storage conditions prior to shipment of the samples to our laboratory and a delay in the analysis. The father (I-I) and brother (II-3) of the propositus had abnormal $\mathrm{MCH}$ values and high Hb F values (16 and 29\%, respectively). This $H b F$ contained $G_{\gamma}$ chains (average $83 \%$ ) and $A \gamma$ chains (average 17\%). The $H b F$ in the mother consisted of $G, A_{\gamma}$, and $A_{\gamma}{ }^{\top}$ chains; the values were $63,16.5$, and $20.5 \%$, respectively. Two other relatives (II-1, II-2) had normal red cell indices.

Fig. 5.2 illustrates data obtained from some of the dot-blot hybridization experiments. The propositus and her mother are carriers of the IVS-I-5 (G) $\boldsymbol{C}$ ) $\beta$-thal allele. A seemingly homozygous condition for this well-known B-thal mutation was detected in the propositus; this however, was excluded because the father was negative for the IVS-I-5 (6)C) mutation. An additional abnormality, inherited from the father, had to be present in trans 


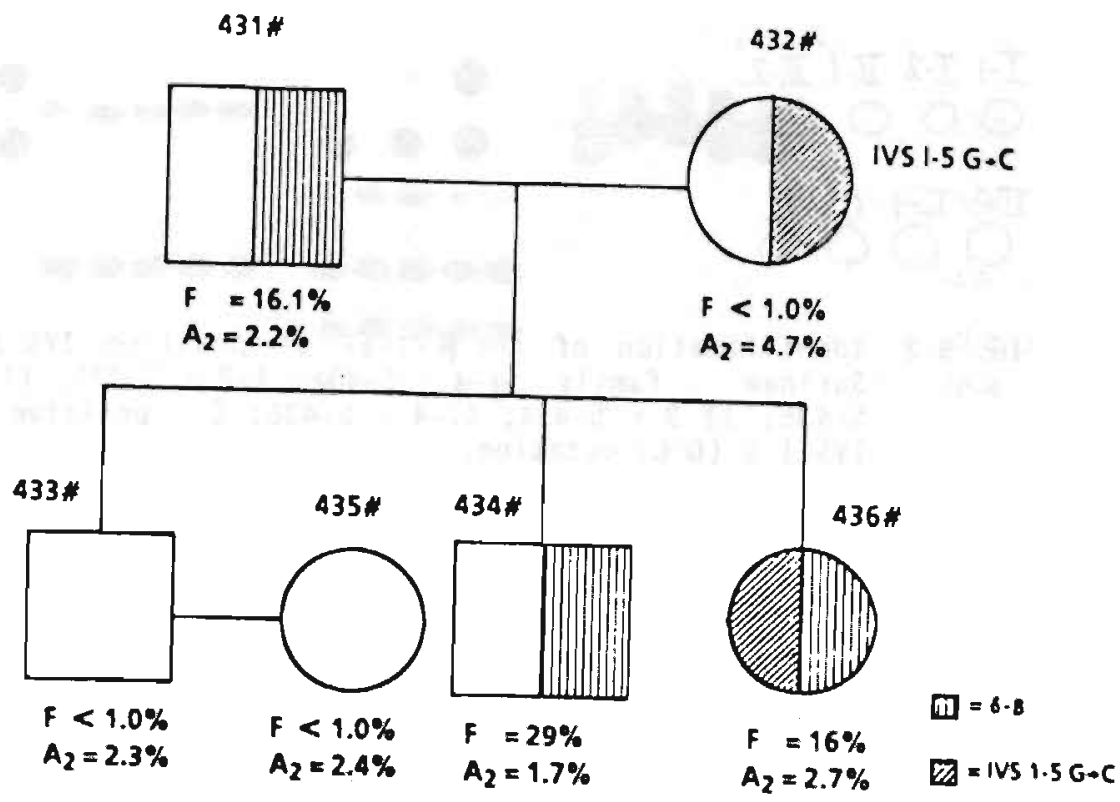

FI6. 5.1 Pedigree of the Surinam $(\delta \beta)^{\circ}$-Thal Family

TABLE 5.1 Haematological and Hb Composition Data of the Surinam $(\delta \beta)^{\circ}$-Thal Family

\begin{tabular}{|c|c|c|c|c|c|c|c|c|c|c|c|}
\hline Case & $\begin{array}{l}\text { Sex- } \\
\text { Age }\end{array}$ & $\begin{array}{c}H b \\
\text { g/d1 }\end{array}$ & $\begin{array}{l}\text { PCV } \\
1 / 1\end{array}$ & $\begin{array}{c}\text { MCV } \\
\mathrm{fl}\end{array}$ & $\begin{array}{c}\mathrm{MCH} \\
\mathrm{pg}\end{array}$ & $\begin{array}{l}\mathrm{MCHC} \\
\mathrm{g} / \mathrm{d} 1\end{array}$ & $A_{2}$ & F & $A_{\gamma}{ }_{\alpha}{ }^{\top}$ & $G_{\gamma}$ & ${ }^{A}{ }_{\gamma} I$ \\
\hline$S-431$ & $M-58$ & 11.5 & .500 & 98 & 22.5 & 23.0 & 2.2 & 16.1 & 0 & 83.7 & 16.3 \\
\hline$S-432$ & $F-50$ & 10.7 & .475 & 92 & 20.7 & 22.3 & 4.7 & $<1.0$ & 20.5 & 63.0 & 16.5 \\
\hline$S-433$ & M-33 & 15.6 & .575 & 120 & 32.6 & 27.1 & 2.3 & $<1.0$ & n.d. & n.d. & n.d. \\
\hline$S-434$ & $M-26$ & 13.4 & .540 & 108 & 26.9 & 24.8 & 1.7 & 29.0 & 0 & 81.0 & 19.0 \\
\hline S-435 & $F-24$ & 12.0 & .430 & 101 & 28.2 & 27.9 & 2.4 & $<1.0$ & n.d & n.d & n.d. \\
\hline$S-436$ & $F-19$ & n.d. & n.d. & n.d. & n.d. & n.d. & 2.7 & 16.0 & 0 & 85.3 & 14.7 \\
\hline
\end{tabular}

to the $\beta$-thal allele of the propositus in order to account for this observation. This abnomality was considered to be a deletion causing a $8 \beta^{\circ}$-thal which in the heterozygote, is characterized by elevated levels of $\mathrm{Hb} F$ and by distinct microcytosis and hypochromia (10). 


\section{0 \\ $\pi-3 \pi-4 c \%$}

FIG. 5.2 Identification of the $\beta$-thal at position IVS-I-5 $(G, C)$ in the Surinam family. $I-1=S-431 ; 1-2=S-432 ; 11-1=S-433 ; 11-2=$ S-435; II-3 = S-434; II-4 $=S-436 ; C=$ positive controls for the IVS-I-5 (G-C) mutation.

4.1 Mapping of the 5' Breakpoint of the $8 \beta$-Thal Deletion. Digestion with Hind III, $B C \bar{I}, \bar{B} \bar{I} \bar{I}, \bar{X} \bar{b} \bar{I}$, and hybridization to a $\gamma$-IVS-II probe gave besides normal, several abnormal fragments (Fig. 5.3, Table 5.2). Digestion with Bam HI, ECORI, and Hpa I produced normal fragments (Table 5.2). The data given in this table also show that the propositus is $t / t$ at the $X m n$ I site $5^{\prime}$ to the $G \gamma$ gene, and $+/+$ and $-1-$ at the Hind III sites in the $G_{r}$ and $A_{r}$ genes, respectively. The $X_{m n} I$ and Hind III sites are known to be polymorphic $(11,12)$.

TABLE 5.2 Summary of Restriction Endonuclease Data for the Surinam $\delta \beta$-Thal DNA Following Hybridization to the $\gamma$-IVS-II Probe

\begin{tabular}{|c|c|c|c|c|c|}
\hline ENZYME & $S-431$ & $S-432$ & $S-433$ & $S-434$ & $S-436$ \\
\hline Bam HI & $15 ; 5$ & $15 ; 5$ & $15: 5$ & $15 ; 5$ & $15 ; 5$ \\
\hline Bgl II & $12.9 ; 10$ & 12.9 & 12.9 & $12.9 ; \underline{10}$ & $12.9 ; 10$ \\
\hline Xba 1 & $\begin{array}{l}7.4 ; 4.9 ; \\
3.2 ; 2.4\end{array}$ & $\begin{array}{l}7.4 ; 4.9 ; \\
3.2\end{array}$ & $\begin{array}{l}7.4 ; 4.9 \\
3.2\end{array}$ & $\begin{array}{l}7.4 ; 4.9 ; \\
3.2 ; 2.4\end{array}$ & $\begin{array}{l}7.4 ; 4.9 ; \\
3.2 ; 2.4\end{array}$ \\
\hline Hind III & $\begin{array}{l}7.5 ; \overline{6.8} \\
3.3\end{array}$ & $\begin{array}{l}6.8 ; 3.3 ; \\
2.5\end{array}$ & n.d. & n.d. & $6.8 ; \overline{3.3}$ \\
\hline Eco RI & $7: 2.7$ & $7 ; 2.7$ & n.d. & n.d. & $7 ; 2.7$ \\
\hline$X m n$ I & n.d. & $\underline{7}$ & n.d. & $7 ; 8$ & 7 \\
\hline Pst I & n.d. & $5.1 ; 4.1$ & n.d. & $5.1 ; 4.1$ & $5.1 ; 4.1$ \\
\hline $\mathrm{BCl} 1$ & n.d. & 18 & n.d. & $18 ; \underline{15.5}$ & $18 ; \underline{15.5}$ \\
\hline Hра I & n.d. & 4.6 & n.d. & 4.6 & 4.6 \\
\hline
\end{tabular}

Bold figures denote a polymorphic site; underlined figures denote an abnormal fragment. 
$15 \mathrm{~kb}$ -

$5 \mathrm{~kb}$ -
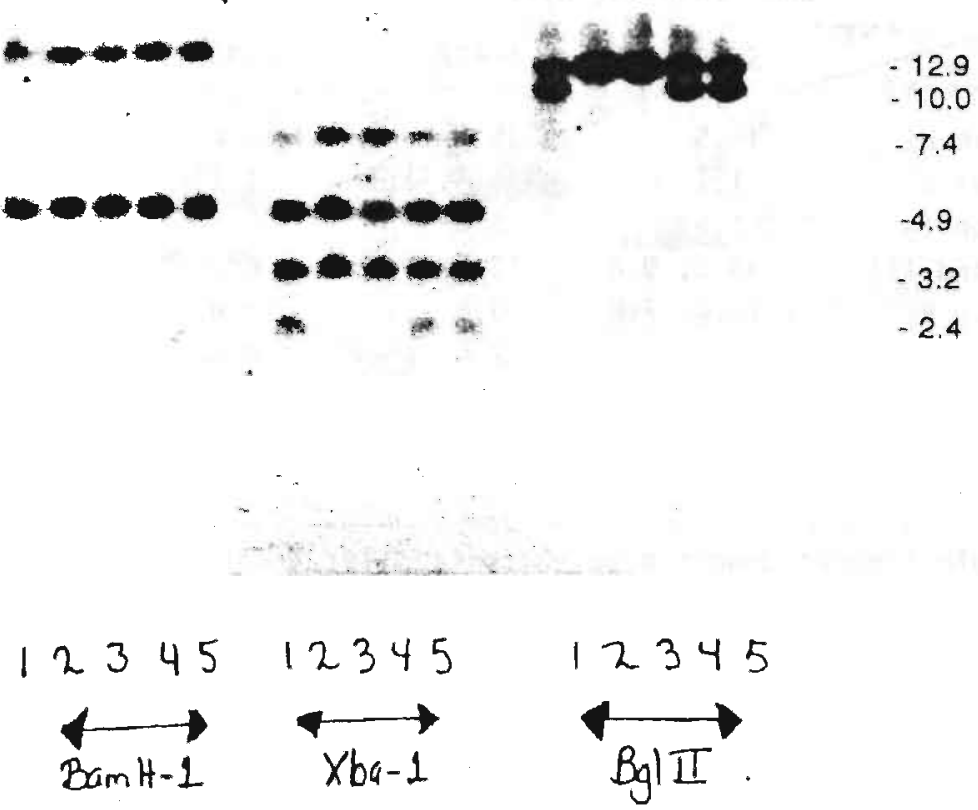

FIG. 5.3 Sizes of fragments obtained after digestion with Bam HI, Xba I, and $\mathrm{Bgl}$ II from members of the Surinam 8 Pamily. See text for details. Lanes $1,2,3,4$, and 5 respectively refer to the following family members: $S-431,5-432, S-433, S-434$, and $S-436$ (see pedigree). The membrane was hybrldized with the $\gamma$-IVS-II probe.

The sizes of the abnormal fragments are similar to those reported for a recently discovered Indian $\delta \beta$ deletion (13). The $5^{\prime}$ breakpoint in this deletion was reported to be about $1 \mathrm{~kb} 3^{\prime}$ of the Ar-globin gene poly A site. By using the sequence data found $3^{\prime}$ of the new Indians 8 -thal (unreported data provided by one of the authors of Ref. 13) a primer set was used to amplify part of the genome containing the deletion breakpoint and the amplified DNA was in part sequenced. Our data confirmed the observation that the Surinam $\delta \beta$ deletion has the exact breakpoint as the new Indian $\delta \beta-t h a l$ described in Ref. 13.

4.2 Kapping the $3^{\prime}$ Endpoint of the Deletion. The $3^{\prime}$ endpoint was mapped by hybridizing the digested genomic DNA with the pRK 28 probe that is located $17 \mathrm{~kb} 3^{\prime}$ to the $\beta$ gene. Abnormal fragments were obtained with Hind III, Eco RI, and Xmn I, but not with Bcl I, Hpa I, Pst I, Xba I, and Bam HI (Table 5.3, Fig. 5.4). The same sites are also deleted in the Black $G_{\gamma}\left(A_{\gamma \varepsilon \beta}\right)^{\circ}$-thal and the Turkish $G_{\gamma}\left(A_{\gamma \beta \beta}\right)^{\circ}$-thal, but with different sizes of the abnormal fragments $(14,15)$. 
TABLE 5.3 Summary of Restriction Endonuclease Data for the Surinam 8 -Thal DNA Following Hybridization to the PRK 28 Probe

\begin{tabular}{|c|c|c|c|c|c|}
\hline$E_{N I Y H E}$ & $S-431$ & $S-432$ & $S-433$ & $\begin{array}{l}S-434 \\
\ldots \ldots\end{array}$ & $\begin{array}{l}5-436 \\
\ldots-\ldots\end{array}$ \\
\hline Bam $\mathrm{KI}$ & 15.5 & 15.5 & 15.5 & 15.5 & 15.5 \\
\hline II II & 1.1 & $5.4 ; 1.1$ & 1.1 & 1.1 & $5.4 ; 1.1$ \\
\hline Xba J & 5.6 & 5.6 & 5.6 & 5.6 & 5.6 \\
\hline Hind III & $13.5 ; \underline{9.8}$ & 13.5 & n.d. & n.d. & $13.5 ; 9.8$ \\
\hline Eco RI & $10.8 ; \overline{7.8}$ & 10.8 & n.d. & n.d. & $10.8 ; \underline{7.8}$ \\
\hline$X m n$ I & n.d. & 12.8 & n.d. & $12.8 ; 10.2$ & $12.8 ; 10.2$ \\
\hline Pst I & n.d. & 9.5 & n.d. & 9.5 & 9.5 \\
\hline $\mathrm{BCl} I$ & n.d. & $3.9 ; 3.6$ & n.d. & $3.9 ; 3.6$ & $3.9 ; 3.6$ \\
\hline $\mathrm{Hpa} \mathrm{I}$ & n.d. & 25 & n.d. & 25 & 25 \\
\hline
\end{tabular}

Bold figures denote a polymorphic site; underlined figures denote an abnormal fragment.

The calculation of the length of the deletion has been simplified by the fact that after digestion with Bam HI no abnormal fragments were found when hybridized with the $\gamma$-IVS-II or the PRK 28 probes. Mapping the different abnormal sizes indicates that the abnormal Bam HI fragment originating from the $8 B$-thal chromosome has the same size $(15.5 \mathrm{~kb})$ as the Bam HI fragment from the $\bar{\beta}$-thal chromosome. As the exact $5^{\prime}$ location of the breakpoint was known, the position of the intact Bam HI site $5^{\prime}$ to the deletion could be determined in relation to the start of the deletion. The distance between this Bam HI site and the breakpoint of the deletion was $2.24 \mathrm{~kb}$, indicating that at the $3^{\prime}$ site, the deletion also extended for $2.24 \mathrm{~kb}$ into the $16 \mathrm{~kb}$ Bam HI fragment obtained from the Hind 111 and Eco RI fragments, that resulted in an average value of $32 \mathrm{~kb}$ for this deletion (Fig. 5.5). The $3^{\prime}$ end of this deletion lies between the $3^{\prime}$ endpoint of the Turkish $\mathbf{G}_{\gamma^{+}}$ $\left(A_{\gamma \& \beta}\right)^{\circ}$-thal and that of the Black $G_{\gamma}+\left(A_{88 \beta}\right)^{\circ}$-thal (16). The Turkish deletion has its $3^{\prime}$ endpoint $48 \mathrm{bp} 3^{\prime}$ to the $6.4 \mathrm{~kb} \mathrm{LI}$ repeat that is located $3^{\prime}$ to the $\beta$-globin gene, while the $3^{\prime}$ endpoint of the Black deletion is located with an LI family repeat located about $3 \mathrm{~kb}$ outside the $6.4 \mathrm{~kb} \mathrm{Ll}$ repeat (Fig. 5.6).

\section{DISCUSSIOH}

Restriction endonuclease mapping analysis made it possible to determine the breakpoints of a large deletion causing a $\delta^{8}$-thal in members of a Surinam family. the $5^{\prime}$ endpoint of the deletion is located $\sim \mathrm{kb} 3^{\prime}$ to the poly $A$ site of the Ar-globin gene, while the $3^{\prime}$ endpoint was found about $0.5 \mathrm{~kb}$ from the $L 1$ region, $6.4 \mathrm{~kb} 3^{\prime}$ of the $\beta$-globin gene. Exactly the same $3^{\prime}$ breakpoint was found in a $\delta \beta$ deletion reported by Mishima et al (13). For several reasons it was not possible for these authors to determine the exact location and size of their reported $\delta \beta$-thal (Indian $\delta \beta-t h a 1)$. It is most likely that the Suriman $(\delta \beta)^{\circ}$-thal and the Indian $8 \beta$-thal are the same, which is supported by the fact that both families are of Surinamese descent. 


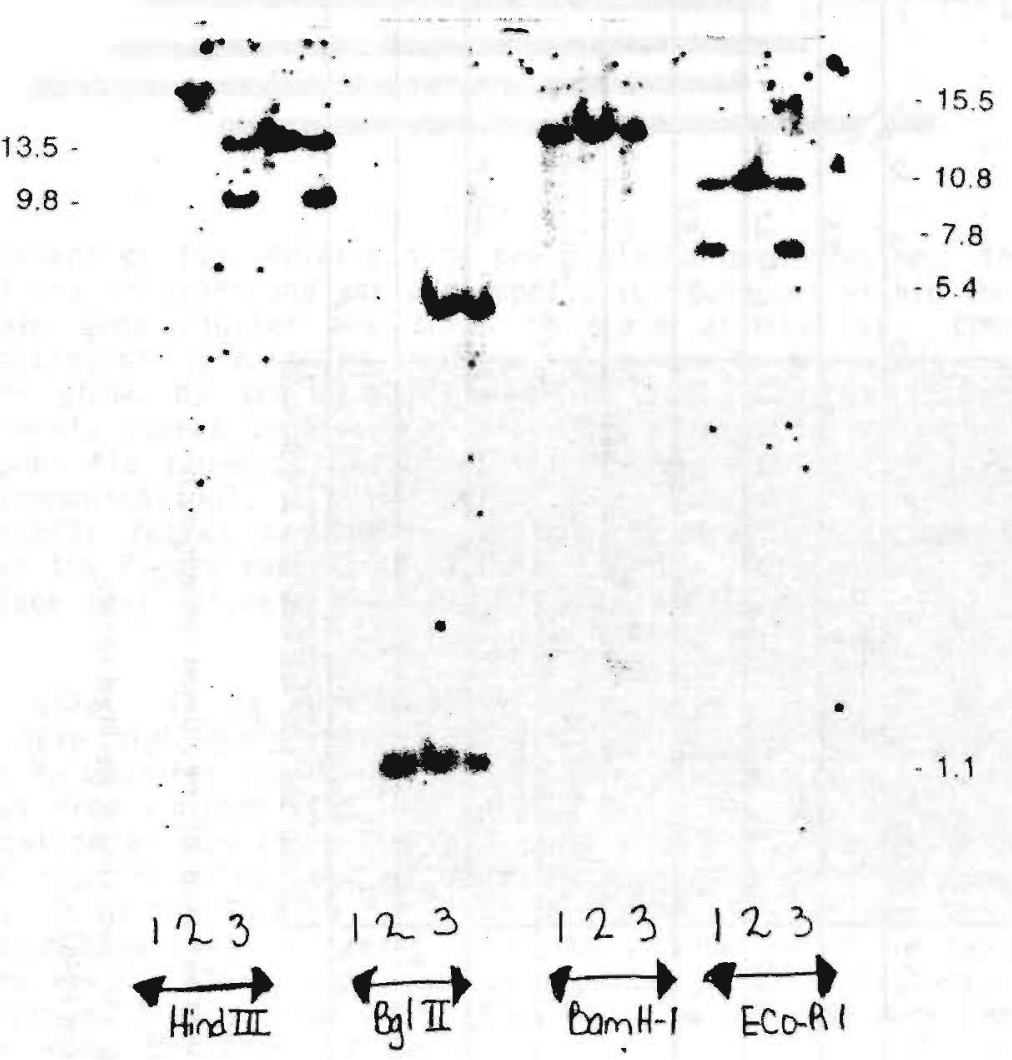

F16. 5.4 Sizes of fragments obtained after digestion with Hind III, Bgl II, Bam HI, and. Eco RI from members of the Surinam $\delta \beta$ family. See text for details. Lanes 1,2 , and 3 respectively refer to the following family members: S-431, S-432, and S-436 (see pedigree). The membrane was hybridized with the PRK 28 probe.

The $3^{\prime}$ deletion endpoint of the Surinam $\delta \beta-$ thal is located between the $3^{\prime}$ endpoints of the Turkish $G_{\gamma}\left(A_{\gamma \beta} \beta\right)^{\circ}$-thal $(15,17,18)$, and the $B$ lack $G_{\gamma}$ $(A \times \& \beta)^{\circ}$-thal $(14,16)$. The Dutch $\beta^{\circ}$-thal $(13)$, the Laotian $(\mathcal{\beta})^{\circ}$-thal $(19)$, and several other $\delta \beta$-thalassaemias, have their endpoints within a few $k b$ $3^{\prime}$ to the endpoint of the Surinam $(\delta \beta)^{\circ}$-thal. The clustering of these endpoints is near or in the L1, Alu, or other repetitive elements that are considered to be "hot spots" for recombination $(20,21)$. At the 5 ' site, the Surinam $\delta \beta$-thal falls into a cluster with the Indian $\left.G_{x}\left(A_{\delta} \delta\right)^{\circ}\right)^{\circ}$-HPFH (20), the Japanese $\delta \beta$-thal (22), the Black HPFH-2 (23), and the Black $G_{\varnothing}$ (A $\left.\delta \beta^{\circ}\right)^{\circ}$-thal (14). It is only with the Black $G_{\gamma}\left(A_{\gamma\{\beta}\right)^{\circ}$-thal that the Surinam $(\delta)^{\circ}$-thal shares clustering of both the $3^{\prime}$ and $5^{\prime}$ areas. A comon mechanism might be involved in generating these deletions. The Surinam i. $\beta$, however, differs from all of the above mentioned $8 \beta$-thal deletions in 


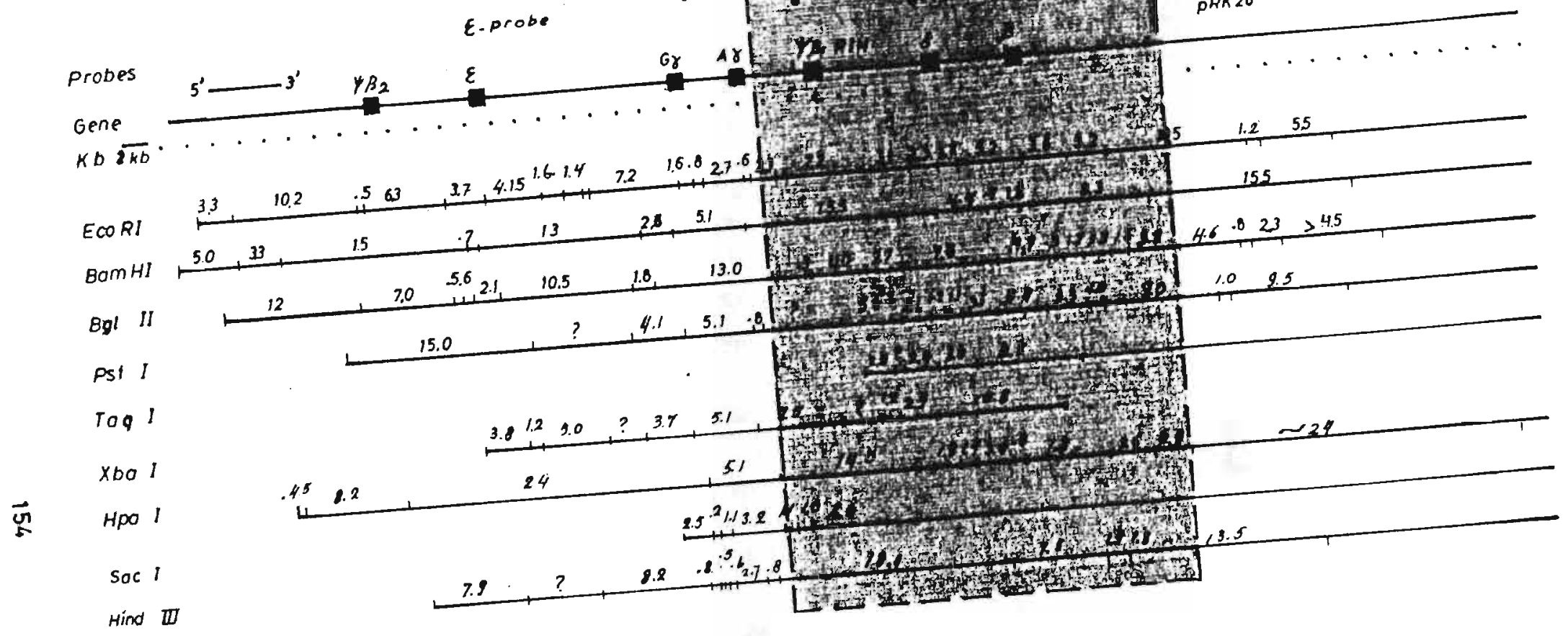

Fig. 5.5 Restriction Endonuclease Map of the Human Hemoglobin Q-like Globin Genes.

box shows the areo that is deleled inthls surina $m$ d-B (halassa emla). 


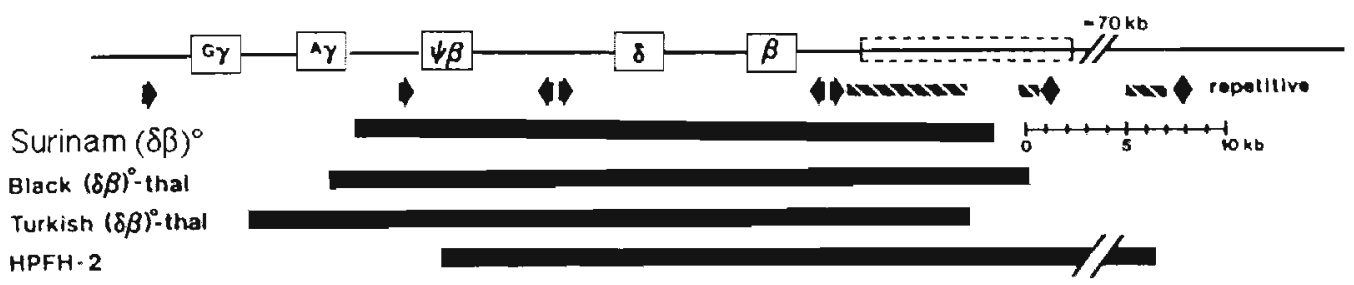

FI6. 5.6 Extent of four deletions in the $\beta$-globin gene cluster. The locations of genes and various repetitive sequences within the $\beta$-globin gene cluster are shown to scale at the top. Open boxes represent gene-coding regions. A break in the scale of $70 \mathrm{~kb}$ is shown by two parallel slanted lines. Arrows represent Alu family repeat sequences of known orientation, and diamonds represent Alu repeats of unknown orientation (P.S. Henthorn, personal comrnunication). Cross-hatched bars show the locations of $L 1$ family repeat sequences. the solid bars in the lower portion of the figure represent the extent of the four indicated deletions (see text for references) (modified from Henthorn et al, 1990).

its unique size. It is interesting that heterozygotes for the Surinam $(\delta \beta)^{\circ}$-thal have high $G_{\gamma}: A_{y}$ ratios $(85: 15)$. This suggests a possible mutation in the $G_{\gamma}$ promoter region. We sequenced the promoter regions of the $G_{\gamma}$ and $A_{\gamma}$ genes from subject II-3, but no abnormalities were found except for the $F C$ mutation at position -158 of the $G_{\gamma}$ gene that is known to be associated with high $G \gamma$ values and an increased $H b F$ production in many conditions (11). Both the Turkish ${ }^{+} \gamma^{+}\left(A_{\gamma} \delta B\right)$ deletion $(36.1 \mathrm{~kb})$ and the Surinam $(88)^{\circ}$ deletion have their $5^{\prime}$ breakpoint $\sim 1 \mathrm{~kb}$ outside one of the two $r$ genes (16). There are no $A l u$ or $L 1$ sequences reported in these regions. Therefore, the regions $1 \mathrm{~kb}$ outside the $\gamma$ genes might be involved more frequently in possible recombinations.

It is of importance to note that the Surinam $8 \beta$-thal deletes the same $\delta-\beta$ intergenic region as is the case for all deletional types of $H P F H$ without leading to a phenotypically similar condition. This $\delta-\beta$ intergenic region was thought to be involved in contributing to the difference noted between the HPFHs and the $\delta \beta$-thalassaemias in foetal $\mathrm{Hb}$ production and the phenotypical differences (24). It still remains unclear what is causing the differences between HPFH phenotypes and $8 \beta$-thal, but based upon our observation the $\delta-\beta$ intergenic region is probably not involved in regulating these differences.

\section{REFERENCES}

1. Bunn, H.F. and Forget, B.G.: Hemoglobin: Molecular, Genetic and Clinical Aspects, W.B. Saunders Company, Philadelphia, 1986.

2. Stamatoyannopoulos, G., Nienhuis, A.H., Leder, P., and Majerus, P.H.: The Molecular Basis of Blood Diseases, H.B. Saunders Company, Philadelphia, 1987. 


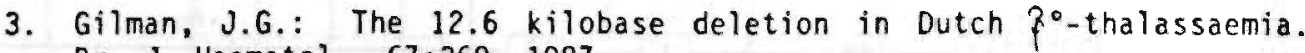
$\mathrm{Br}$. J. Haemato1., 67:369, 1987 .

4. Camaschella, C., Serra, A., Gottardi, E., Revelio, D., Mazza, U., and Saglio, G.: A new hereditary persistence of fetal hemoglobin deletion has the breakpoint within the $3^{\prime}$ S-globin gene enhancer. Blood, 75: $1000,1990$.

5. Efremov, G.D., Filipce, V., Gjorgovski, I., Juricic, D., Stojanovski, N., Harano, T., Nakatsuji, T., Kutlar, A., Kutlar, F., Bakioglu, I., and Huisman, T.H.J.: G $A_{\gamma}(\delta \hat{\phi})^{\circ}$-Thalassaemia and a new form of $x$ globin gene triplication identified in the Yugoslavian population. Br. J. Haematol., 63:17, 1986.

6. Kutlar, F., Kutlar, A., and Huisman, T.H.J.: Separation of normal and abnormal hemoglobin chains by reversed-phase high-performance liquid chromatography. J. Chromatogr., 357:147, 1986.

7. Kutlar, A., Kutlar, F., Gu, L-G., Mayson, S.M., and Huisman, T.H.J.: Fetal hemoglobin in normal adults and $\beta$-thalassemia heterozygotes. Hum. Genet., 85:106, 1990.

8. Bisse, E. and Wieland, H.: High-performance liquid chromatographic separation of human haemoglobins - Simultaneous quantitation of foetal and glycated haemoglobins. J. Chromatogr., 434:95, 1988.

9. Huisman, T.H.J. and Jonxis, J.H.P.: The Hemoglobinopathies Techniques of Identification, Clinical and Biochemical Analysis, Vol. 6, Marcel Dekker, Inc., New York, 1977.

10. Weatherall, D.J. and Clegg, J.B.: The Thalassaemia Syndromes, 3rd edition, Blackwell Scientific Publications, Oxford, 1981.

11. Gilman, J.G. and Huisman, T.H.J.: DNA sequence variation associated with elevated fetal Gr globin production. Blood, $66: 783,1985$.

12. Orkin, S.H., Kazazian, H.H., Jr., Antonarakis, S.E., Goff, S.C., Boehm, C.D., Sexton, J.P., Waber, P.G., and Giardina, P.J.V.: Linkage of P-thalassaemia mutations and $\beta$-globin gene polymorphisms with DNA polymorphisms in human $\beta$-globin gene cluster. Nature, 296:627, 1982.

13. Mishima, N., Landman, H., Huisman, T.H.J., and Gilman, J.G.: "The DNA deletion in an Indian $8 \dot{\beta}$-thalassaemia begins one kilobase from the $A_{\gamma}$ globin gene and ends in an $\mathrm{Ll}$ repetitive sequence. Br. J. Haematol., 73:375, 1989.

14. Henthorn, P.S., Smithies, 0., Nakatsuji, T., Felice, A.E., Gardiner, M.B., Reese, A.L., and Huisman, T.H.J.: (Ay\&B) $)^{\circ}$-Thalassaemia in Blacks is due to a deletion of $34 \mathrm{kbp}$ of DNA. Br. J. Haematol., 59:343, 1985.

15. Tuan, D., Feingold, E., Newman, M., Weissman, S.M., and Forget, B.G.: Different $3^{\prime}$ endpoints of deletions causing $8 \beta$-thalassemia and hereditary persistence of fetal hemoglobin: Implications for the control of $\gamma$ globin gene expression in man. Proc. Nat. Acad. Sci. USA, 80: $6937,1983$.

16. Henthorn, P.S., Smithies, 0., and Mager, D.L.: Molecular analysis of deletions in the human $\beta$ globin gene cluster: Deletion junctions and locations of breakpoints. Genomics, $6: 226,1990$.

17. Fritsch, E.F., Lawn, R.M., and Maniatis, T.: Characterization of deletions which affect the expression of fetal globin genes in man. Nature, 279:598, 1979.

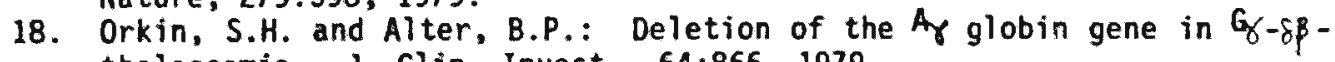
thalassemia. J. Clin. Invest., 64:866, 1979.

19. Zhang, J-W., Stamatoyannopoulos, G., and Anagnou, M.P.: Laotian (\& $\beta)^{\circ}-$ thalassemia: Molecular characterization of a novel deletion associated with increased production of fetal hemoglobin. Blood, 72:983, 1988 . 
20. Henthorn, P.S., Mager, D.L., Muisman, T.H.J., and Smithies, 0.: A gene deletion ending within a complex array of repeated sequences $3^{\prime}$ to the human $\beta-g l o b i n$ gene cluster. Proc. Natl. Acad. Sci. USA, 83: $5194,1986$.

21. Mager, D.L., Henthorn, P.S., and Smithies, 0.: A Chinese Grt(Arr B)Thalassemia deletion: Comparison to other deletions in the human $\beta$ globin gene cluster and sequence analysis of the breakpoints. Nucleic Acids Res., 13:6559, 1985.

22. Matsunày, E., Kimura, A., Yamada, H., Fukumaki, Y., and Takagi, Y.: A novel deletion in $8 \beta$-thalassemia found in Japan. Biochem. Biophys. Res. Commun., 126:185, 1985.

23. Kutlar, A., Gardiner, M.B., Headlee, M.G., Reese, A.L., Cleek, M.P., Nagle, S., Sukumaran, P.K., and Huisman, T.H.J.: Heterogeneity in the molecular basis of three types of hereditary persistence of fetal hemoglobin and the relative synthesis of the $G_{\gamma}$ and $A_{\gamma}$ types of $\gamma$ chain. Biochem. Genet., 22:21, 1984.

24. Huisman, T.H.J., Schroeder, W.A., Efremov, G.D., Duma, H., Mladenovski, B., Hyman, C.B., Rachmilewitz, E.A., Bouver, N., Miller, A., Brodie, A., Shelton, J.R., Shelton, J.B., and Apell, G.: The present status of the heterogeneity of fetal hemoglobin in B-thalassemia: An attempt to unify some observations in thalassemia and related conditions. Ann. N.Y. Acad. Sci., 232:107, 1974. 
SUMMARY 


\section{SUMMARY}

The basis of the investigation described in this thesis is the study of haemoglobinopathies in the Surinam population. Special attention has been paid to newly developed and advanced techniques, such as polymerase chain reaction (PCR) and its application to techniques, such as oligonucleotide specific probing (dot blot) and single strands' DNA sequencing (ss DNA). Were possible, clinical data of the Surinam patients with haemoglobinopathies have been compared with similar patient groups described elsewhere to investigate similarities or differences. Untill now, the lack of adequate knowledge in the field of haemoglobinopathies is responsible for a certain rigidity in the medical management of haemoglobinopathy patients. It is not excluded that this rigidity in some cases leads to excess morbidity and even premature death of these patients.

The patients' material for investigation has been collected randomly from the Paramaribo hospital clinics (Academic Hospital, Diakonessenhuis, 's Lands Hospitaal and St.Vincentius Hospital) and from patients and their relatives who were known with the disease to the medical staff and general practitioners. A total number of blood samples from over 600 individuals have been studied. It should be mentioned that most samples were obtained from the hospital where the majority of births is found ('s Lands Hospitaal).

In chapter 1 a review is given on haemoglobinopathy. Attention has been paid to classification and expression regulation of the different globin genes. It has been explained that selective expression of individual globine genes during ontogenesis is regulated on the level of gene transcription by:

a) cis-acting regulatory control DNA sequences that are part of a globin gene or are nearly within the globin gene cluster, and

b) trans-acting regulatory proteins interacting with the control sequences.

In paragraph 5 of this review numerous models have been proposed to explain the properties of the different regulation sequences.

Several haemoglobin variants with their pathophysiological consequences, which are found in the Surinam population, have also been discussed.

In the paragraph on thalassaemia, the $\alpha$-thalassaemias were discussed as the first group. They are caused by deletion (the deletion types) or mutations (non-deletion types) of (or in) one to four of the $\alpha$-genes. The resulting disorders involve various degrees of imbalance between $\alpha$ - and $\beta$-chain synthesis, and patients can be classified using haematological, biochemical and molecular criteria.

$\beta$-Thalassaemia is an extremely heterogeneous group of disorders of haemoglobin synthesis, and is due to a decrease $\left(\beta^{+}\right)$or absence $\left(\beta^{\circ}\right)$ of $\beta$ - 
globin chain synthesis. More than 100 different $\beta$-thalassaemia genes have been identified. At the molecular level, $\beta$-thalassaemia is due to deletions of part or all of the $\beta$-globin gene (deletion types) or more often to point mutations which include single base changes, and deletions and insertions of one to four nucleotides (non-deletion types). A special form of $\beta$-thalassaemia are the $\partial-\beta$-thalassaemias, which are associated with externsive deletions of varying lengths, involving the $\partial-$, the $\beta$ - and often the $\gamma$-genes. They are characterized by a normal $\mathrm{Hb} \mathrm{A}_{2}$-level (1.6-3.5\%), a markedly raised $\mathrm{Hb} F$ level and varying degrees of anaemia in the heterozygote patient. All the so far characterized $\partial-\beta$ types are the result of non homologous recombinations in sopecific parts of the genome.

The last group of thalassaemias discussed in this review are the HPFH's (Hereditary Persistence of Fetal Haemoglobin). HPFH is a clinically benign condition characterized by the continued expression of one or both of the $\gamma$ genes in adult life; these genes are normally expressed at significant levels in the fetal period only. HPFH's are classified by molecular analysis in deletion- or non-deletion types.

The use of restriction endonuclease for the detection of normal variations in DNA structures (polymorphism) is described in the last paragraph of this review chapter.

In chapter 2, methods and techniques and also the biological specimens used in our investigations are described in detail.

Chapter 3 deals with structural haemoglobin variants found in the population of Surinam.

Chapter 3a. Three different haemoglobinopathies, i.e. HbS, Hb Chad $[\alpha 23(B 4) G l u \rightarrow L y s]$, and $\alpha$-thal-2(-3.7kb) have been observed in eight members of a family. The propositus had all three abnormalities, while her mother and four of her half-brothers had $\mathrm{Hb}$ Chad together with an $\alpha$-thal-2 heterozygosity or homozygosity. Gene-mapping and dot-blot analysis of amplified DNA identified a $G \rightarrow A$ mutation in codon 23 of the $\alpha 2 \beta 1$ hybrid gene resulting in the Gly $\rightarrow$ Lys substitution. The quantity of $\alpha$-Chad chain averaged $31.5 \%$ in its carriers with an additional $\alpha$-thal-2 heterozygosity $\left[-\alpha^{\text {chad }}(-3.7 \mathrm{~kb}) /-\alpha(-3.7 \mathrm{~kb})\right]$. These quantities are considerably higher than those reproted for families from Chad, China and Japan; the low levels of $14.5-24 \% \mathrm{Hb}$ Chad in members of these familiers suggest a mutation on a chromosome with two $\alpha$-globin genes [ $\alpha \alpha^{\text {chad } / \alpha \alpha \text { or } \alpha^{\text {chad }} \alpha / \alpha \alpha \text { ]. }}$

In chapter $3 b$ the most common $\mathrm{Hb}$ variant in the Surinam population, i.e. $\mathrm{HbS}$, is described.

Haematological and genetic data have been collected for twelve SS, one SC 
and four S- $\beta$-thal patients and their relatives. Haplotyping, using ${ }^{32} \mathrm{P}$-labelled oligonucleotide specific probes, identified haplotypes $\# 19$ and $\# 20$ as the major types among the Surinam population. Both haplotypes have been reported to originate from West and Central Africa. These results suggest that the $\beta^{s}$ gene among Surinamese was introduced by the slave trade, common in the 19th century in that part of the world. Haematological data showed that AS individuals are clinically normal, while the SS patients have a severe anaemia with a variety of complications, comparable to those observed for SS patients from Africa and the United States of America. The AS individuals did not have significantly increased levels of circulating toetal haemoglobin $(\mathrm{HbF}<1 \%$ ), while the foetal $\mathrm{Hb}$ level in the twelve SS patients averaged about $10 \%$.

Chapter 4 deals with thalassaemias in the Surinam population.

In chapter $4 a$, it is described that twenty Surinamese families with $\beta$-thal were screened for particular mutations using ${ }^{32} \mathrm{p}$ labelled oligonucleotide probes, sequence analysis and gene mapping. Thirteen different mutations were detected. The IVS-I-5 (G $\rightarrow \mathrm{C})$ was the most frequently observed, being present in six of the twenty families, followed by the frameshift at codons $41 / 42$ (-TTCT) that was observed in three families. The Creole and Javanese ethnic groups were the most heterogeneous. Seven different mutations $[-88(C \rightarrow T) ;-29(A \rightarrow G)$; codons 41/42 (-TTCT); codon $47(+A)$; IVS-1-849 $(A \rightarrow G) ; \quad$ IVS-II-1 $(G \rightarrow A) ; \quad-28 \quad(A \rightarrow G) ; 1.393 \mathrm{~kb}$ deletion] were found in eight Creole families and four mutations in five Javanese families [IVS-1-5 $(\mathrm{G} \rightarrow \mathrm{C})$; codons 8/9 $(+\mathrm{G})$; codon $35(-\mathrm{C})$; IVS-1-2 $(\mathrm{T} \rightarrow \mathrm{C})]$. Three different $\beta$-thal alleles were detected in six Hindustani families [IVS-I-5 $(G \rightarrow C)$; codons $41 / 42(-T T C T)$, and a $\partial \beta$-thal due to a $31.6 \mathrm{~kb}$ deletion]. One family, of Libanese origin, had the frameshift at codons $41 / 42$ (-TTCT). A unique frameshift mutation was detected in one family belonging to the Surinam Creole group [codon $47(+A)$ ].

In chapter $4 \mathrm{~b}$, haematological and $\mathrm{Hb}$ composition data are presented for fourteen members of a Surinam family (and for one unrelated subject) with either a $\beta$-thal heterozygosity [five with the $-29(A \rightarrow G) \beta^{+}$mutation and five with the IVS-II-849 $(A \rightarrow G) \beta^{\circ}$ mutation] or a compound heterozygosity (the five remaining patients). Identification of the mutation was by hybridization of amplified DNA with ${ }^{32} \mathrm{P}$-labelled synthetic oligonucleotides. The data indicate distinct differences between the two groups of heterozygotes, mainly in degree of microcytosis and hypochromia, in $\mathrm{Hb} \mathrm{A}_{2}$ levels, and in the level of $G y$ (high in the -29 heterozygotes and low in the IVS-11-849 heterozygotes). The five compound heterozygotes had a thalassaemia intermedia with high $\mathrm{Hb} F$ levels (high ${ }^{G} \mathrm{y}$ ), elevated $\mathrm{Hb} \mathrm{A}$, and $\mathrm{Hb}$ A levels comparable to those 
seen in patients with a homozygosity for the -29 mutation or with the combination of this $\beta^{+}$-thal and $\mathrm{Hb} \mathrm{S}$. An $\alpha$-thal-2 heterozygosity (-3.7 kb deletion) was present in two patients. Their haematological data were improved over those for the patients with four $\alpha$-globin genes; one was the mother of two sets of twins. The high ${ }^{G} \gamma$ value in the $\mathrm{Hb} \mathrm{F}$ of the compound heterozygotes suggests that the high $\mathrm{Hb} F$ production in the condition is mainly directed by the chromosome with the $-29(A \rightarrow G)$ mutation.

Chapter 4c: $\mathrm{Hb} A_{2}$ and its variant $\mathrm{Hb} \mathrm{A}_{2}^{\prime}$ or $\mathrm{B}_{2}$ [216(A13)Gly $\rightarrow$ Arg] were quantitated in the blood of subjects with three different types of $\beta$-thal, and with the $\partial-\mathrm{B}_{2}$ anomaly in cis or in trans to the $\beta$-thal determinant. In one family, the $\partial-\mathrm{B}_{2}$ mutation was in cis to a newly discovered codon $47(+\mathrm{A})$ frameshift. The levels of $\mathrm{Hbs} \mathrm{A}_{2}$ and $\mathrm{B}_{2}$ were nearly the same and about $70 \%$ higher than those in simple $\mathrm{Hb} \mathrm{B}_{2}$ heterozygotes. In two additional families, the $\partial-\mathrm{B}_{2}$ variant was in trans to either a deletional $\beta$-thal (1392 bp) involving part of the $\beta$-globin gene and part of the $\beta$-globin gene promoter, or to the $-88(C \rightarrow T)$ promoter mutation. In both instances, the $\mathrm{Hb} \mathrm{B}_{2}$ level was increased by $80 \%$, but the $\mathrm{Hb} \mathrm{A_{2 }}$ level was increased by 270 and $\sim 200 \%$ respectively. These data indicate two mechanisms that will cause an increase in $\partial$ chain production. One is consistent with a general mechanism concerning the relative excess of $\alpha$ chains in $\beta$ chain deficiencies which will combine with $\partial$ chains to form variable levels of $\mathrm{Hb} A_{2}$, dependent upon the severity of the $\beta$ chain deficiency. The second concerns the loss of $\beta$-globin gene promoter activity, perhaps by an absence of (or decreased) binding of (a) specific protein(s) to this segment of DNA, and a concomitant increase in d-globin gene promoter activity in cis.

In chapter $4 d$, compound heterozygosity for the combination $\mathrm{HbE}$ and $\beta$ thalassaemia is described.

During our survey for haemoglobinopathies in the Surinam population, six families were observed with $\mathrm{Hb} \mathrm{E}-\beta$-thal. A detailed comparison was made of the clinical condition, haematological data, $\mathrm{Hb}$ composition, and types of alleles present in these Surinam E- $\beta$-thal patients and with those of 28 patients from Malaysia, China and Georgia (USA). The majority of the 28 patients were attending a haematology clinic in Kuala Lumpur (Malaysia), five were from the southern part of China, and the one patient (D.D) from Georgia was of mixed Korean-Italian descent. All patients from Surinam with the $E$ - $\beta$-thal condition were descendants of immigrants from Indonesia or India. A total of 54 chromosomes from 27 individuals were analyzed, mainly by hybridization with specific oligonucleotide probes after DNA amplification. Six different $\beta$-thal mutations, including the $\beta^{\mathrm{E}}$ mutation, were detected in he six Surinam families; also detected was a rare splice junction mutation, 
IVS-1-2 $(T \rightarrow C)$, which was previously found in an American Black teenager and in an Algerian child.

Chapter 5 describes a unique form of $\partial \beta$-thal that has been observed in two generations of a Surinam family of Asian-Indian descent. The propositus is a 19-year-old female who received monthly blood transfusions. DNA from members of this family were studied through restriction enzyme analysis. Gene mapping studies showed no abnormal $\alpha$-globin gene rearrangements in any of the six family members. Studies on the $\beta$-globin gene locus using the $\beta$-IVS-II and pRK 28 probes, indicated the presence of an extensive deletion including the $\beta, \partial$ and $\psi \beta$ genes. The $3^{\prime}$ breakpoint of this deletion maps $1 \mathrm{~kb} 3^{\prime}$ to the ' $\gamma$ gene, while the deletion ends approximately $10 \mathrm{~kb} 3^{\prime}$ to the $\beta$ gene, just outside a region of repetitive sequences named Kpn 1 or L1. The minimum size for this deletion is estimated to be $31.6 \mathrm{~kb}$. An IVS=I-5 $(\mathrm{G} \rightarrow \mathrm{C})$ mutation causing $\beta$-thal was present in the propositus, in trans of the $\partial \beta^{\circ}$ deletion. Rather high foetal $\mathrm{Hb}$ levels (16-29\%) were observed in the Surinam $(\partial \beta)^{\circ}$ heterozygotes with a ${ }^{{ }^{a}} \gamma:{ }^{A} \gamma$ ratio averaging 85:15. 
SAMENVATTING 


\section{SAMENVATTING}

De studie van haemoglobinopathieën in de Surinaamse samenleving, met behulp van nieuw ontwikkelde technieken zoals de polymerase chain reaction (PCR) en daaraan gekoppelde technieken zoals oligonucleotide specifieke probing (dot blot) en enkele strengs DNA (ss DNA) sequencing, vormen de basis van het in dit proefschrift beschreven onderzoek. Waar mogelijk zijn bij het in dit proefschrift beschreven onderzoek, klinische gegevens van Surinaamse haemoglobinopathiepatiënten vergeleken met vergelijkbare groepen in de literatuur om analogieën of verschillen aan te tonen. Het ontbreken tot nu toe van voldoende kennis op dit gebied leidt nog tot een verstarring in het nemen van beslissingen rond het medisch handelen bij haemoglobinopathie patiënten, dit kan vervolgens tot een verkorting van de levensduur van deze patiënten aanleiding geven.

Het patiëntenmateriaal is random verzameld uit de diverse ziekenhuisinstellingen (Academisch Ziekenhuis, Diakonessenhuis, 's Lands Hospitaal, Sint Vincentius Ziekenhuis) van Paramaribo en van patiènten en hun familieleden die bij de artsen bekend stonden als haemoglobinopathie patiënten. In totaal werden zo bloedmonsters van meer dan 600 individuen bestudeerd. Hierbij werden tevens 201 navelstreng-bloedmonsters bestudeerd om zodoende de frequentie van haemoglobineafwijkingen in de Surinaamse samenleving te bepalen. Dit materiaal werd v.n.l. verzameld uit het ziekenhuis met de meeste bevallingen per jaar n.l. 's Lands Hospitaal.

In hoofdstuk 1 wordt een overzicht gegeven van de diverse haemoglobino-pathieen, waarbij tevens aandacht besteed is aan de classificatie en de expressie-regulatie van de diverse globinegenen. Aangegeven wordt dat de selectieve expressie van individuele globinegenen gedurende de ontogenese gereguleerd wordt op het niveau van gen transcriptie door:

a) cis-acterende regulatie van DNA sequenties welke weetsel specifieke en ontwikkelings specifieke patronen van expressie vertonen;

b) trans-acterende regulatie eiwitten die in interactie zijn met de regulatieDNA sequenties.

Verschillende modellen die voorgesteld worden om de eigenschappen van de verschillende regulatiesequenties te verklaren worden in paragraaf 5 van deze review besproken. Verder worden de diverse haemoglobinevarianten die in de Surinaamse samenleving aangetoond zijn tezamen met hun pathofysiologie besproken.

Bij de thalassaemieën worden allereerst de $\alpha$-thalassaemieen besproken. Deze zijn onderverdeeld in de deletie en de non-deletie typen. Het resultaat van deze deleties bestaat uit verschillende gradaties van onbalans tussen $\alpha$ 
en $\beta$ ketens. Door gebruik te maken van haematologische, biochemische en moleculaire criteria kunnen patienten geclassificeerd worden. De $\beta$-thalassaemie is een extreem heterogene groep van $\mathrm{Hb}$ synthese afwijkingen en wordt veroorzaakt door een verminderde $\left(\beta^{+}\right)$of atwezige $\left(\beta^{\circ}\right)$ produktie van het $\beta$-globine. Er zijn meer dan 100 verschillende $\beta$-thalassaemie genen geïdentificeerd. Op moleculair niveau wordt $\beta$-thalassaemie veroorzaakt door deleties van gedeelten of van alle $\beta$-globinegenen, of veel vaker door punt mutaties, wat inhoudt single base veranderingen en deleties of inserties van 1 tot 4 nucleotiden. Een bijzondere vorm van $\beta$-thalassaemie zijn de $\partial-\beta$ thalassaemieën die gekarakteriseerd worden door een normaal $\mathrm{HbA}_{2}$ niveau $(1,6-3,5 \%)$, een sterk verhoogd $\mathrm{HbF}$ gehalte, en verschillende gradaties van anaemie bij de heterozygote patient. Alle tot nu toe ontdekte $\partial-\beta$ typen zijn het resultaat van niet homologe recombinaties in specifieke gedeelten van het genoom.

De laatste groep van thalassaemieën welke in deze review besproken worden zijn de HPFH's (Hereditary Persistence of Fetal Haemoglobin). Dit is een klinisch benigne conditie, gekarakteriseerd door de continue expressie van één of beide $\gamma$-globine genen bij volwassenen. De $\gamma$-genen worden normaliter alleen tijdens het foetale stadium in voldoende kwantiteit geproduceerd. De HPFH's worden moleculair genetisch ingedeeld in deletie en nietdeletie typen.

Haplotypering met behulp van restrictie enzym analyse voor het aantonen van normale variaties in DNA-structuren (polymorphisme) wordt beschreven in de laatste paragraaf van dit hoofdstuk.

In hoofdstuk 2 worden de methoden, technieken en het bij het onderzoek gebruikte materiaal uitgebreid beschreven.

Hoofdstuk 3 behandelt structurele varianten van haemoglobine in de bevolking van Suriname.

In hoofdstuk $3 a$ wordt een Surinaamse familie beschreven waarbij 3 verschillende haemoglobinopathieën, $\mathrm{HbS}$, HbChad $\left[\alpha_{23}\left(B_{4}\right) \mathrm{Glu} \cdots\right.$ Lys], en $\alpha$-thal-2 $(-3,7 \mathrm{~kb})$ werden gevonden. De propositus had alle 3 abnormaliteiten, terwijl haar moeder en 4 van haar half-broers het HbChad haemoglobine hadden tezamen met een $\alpha$-thalassaemie-2 heterozygotie of homozygotie. Gene mapping en dot-blot analysen van geamplificeerd DNA toonden een $\mathrm{G} \rightarrow$ A mutatie in codon 23 van het $\alpha_{2} \alpha_{1}$ hybridegen welke resulteerde in een Glu $\rightarrow$ Lys substitutie. Het percentage van de $\alpha$-Chad keten bij de heterozygote dragers die een additionele $\alpha$-thalassaemie-2 heterozygotie [$\left.\alpha^{\text {chad }}(-3,7 \mathrm{~kb} / \alpha \alpha)\right]$ hadden, bedroeg gemiddeld $31,5 \%$, en $43 \%$ bij de 2 heterozygote $\alpha$-Chad dragers met een additionele $\alpha$-thalassaemie-2-homozygotie $\left[-\alpha^{\text {chad }}(-3,7 \mathrm{~kb}) /-\alpha(3,7 \mathrm{~kb})\right]$. Deze percentages zijn aanzienlijk 
hoger dan die gepubliceerd zijn voor families uit Chad, China en Japan. Het lage percentage van $14,5-24 \% \mathrm{Hb}$ Chad bij leden van deze families duidde op een mutatie van een chromosoom met $2 \alpha$-globine genen [ $\alpha \alpha^{\text {chad } / \alpha \alpha}$ of $\left.\alpha^{\text {chad }} \alpha / \alpha \alpha\right)$.

In hoofdstuk $3 b$ wordt de meest voorkomende Hb-variant in de Surinaamse samenleving besproken, $\mathrm{nl}$. het HbS. Haematologische en genetische gegevens zijn verzameld van twaalf $S S$, één Sc en vier $S-\beta$ thalassaemie patiēnten en hun families. Door middel van haplotypering, waarbij gebruik gemaakt is van ${ }^{32} \mathrm{P}$ gelabelde oligonucleotide specifieke probes, zijn de haplotypen \#19 en \#20 aangetoond als de meest voorkomende in de Surinaamse samenleving. Beide haplotypen zijn afkomstig uit West en Centraal Afrika. Deze resultaten geven weer dat het $\beta^{s}$ gen welke aanwezig is in de Surinaamse bevolking, geïntroduceerd is ten tijde van de slavenhandel in de $19^{e}$ eeuw. Haematologische gegevens tonen aan dat de AS individuen klinisch normaal zijn, terwijl de SS patiënten een ernstige anemie hadden met een variëteit van complicaties, vergelijkbaar met die, geobserveerd zijn voor SS patiënten uit Afrika en de Verenigde Staten van Amerika. De As individuen hadden geen significante verhoging van circulerend foetaal haemoglobine (HbF $<1 \%$ ), terwijl bij de 12 SS patiēnten het foetaal haemoglobine gemiddeld $10 \%$ bedroeg.

Uit bestudering van 201 navelstrengbloedjes blijkt dat $10 \%$ van de creolen drager is van het sikkelcel gen, een percentage welk elders (USA, Nederland) ook gevonden wordt voor de negroïde populatie.

Hoofdstuk 4 geeft een overzicht van de verschillende vormen van thalassaemie in Suriname.

In hoofdstuk $4 a$ worden de verschillende $\beta$-thalassaemie genen die gekarakteriseerd zijn tijdens dit onderzoek weergegeven. Twintig Surinaamse families met $\beta$-thalassaemie werden gescreend, voor specifieke mutaties, waarbij gebruik gemaakt is van ${ }^{32} \mathrm{P}$-gelabelde oligonucleotide probes, sequencing en gene mapping. Dertien verschillende mutaties werden er ontdekt.

De IVS I-5 (G $\rightarrow$ C) werd het meest aangetoond, en was aanwezig in zes van de 20 families, gevolgd door de frame shift van codons $41 / 42$ (- TTCT) welke bij 3 families werd aangetroffen. De Javaanse en Creoolse ethnische groep waren de meest heterogene. Zeven verschillende mutaties $[-88(\mathrm{C} \mathrm{-.}$ T); -29 (A $\rightarrow \mathrm{G})$; codons 41/42 (-TTCT); codon 47(+A); IVS-II-849 (A $\rightarrow \mathrm{G})$; IVS-II-1 (G -- A); -28 (A -. G); 1,393 kb deletie] werden gevonden in 8 creoolse families en vier mutaties in vijf Javaanse families [IVS 1-5 (G -.. C); codons $8 / 9(+\mathrm{G})$; codon $35(-\mathrm{C})$; IVS-I-2 (T -. C). Drie verschillende $\beta$ thalassaemie allelen werden ontdekt bij 6 Hindoestaanse families [IVS 1-5 
(G ... C); codons $41 / 42$ (-TTCT) en een $\partial-\beta$ thalassaemie met een deletie van $31,6 \mathrm{~kb}]$.

Een familie van Libanese origine had de frameshift codon 41/42 (-TTCT). Een unieke frameshift mutatie werd ontdekt in een Surinaams Creoolse familie [codon $47+(A)]$.

In hoofdstuk $4 \mathrm{~b}$ wordt een grote Surinaamse familie van Creoolse origine beschreven, waarbij een dubbele heterozygotie voor een $\beta^{+}$en een zeldzame $\beta^{0}$ thalassaemie werd gevonden. Haematologische en $\mathrm{Hb}$ compositie data zijn weergegeven voor 14 leden van deze Surinaamse familie (en voor één niet gerelateerd individu) met een $\beta$-thalassaemie heterozygotie [vijf met de $-29\left(A \ldots\right.$ G) $\beta^{+}$mutatie en vijf met de IVS II-849 (A $\ldots$ G) $\beta^{0}$ mutatie] of een dubbele heterozygotie (de vijf resterende patiënten).

Identificatie van de mutatie werd verricht d.m.v. hybridisatie van geamplificeerd DNA met ${ }^{32} \mathrm{P}$-gelabelde synthetische oligonucleotiden. De resultaten indiceren duidelijke verschillen tussen de 2 heterozygote groepen, voornamelijk in de mate van microcytosis en hypochromie, in $\mathrm{HbA}_{2}$ waarden, en in de waarden van ${ }^{G} \gamma$ (hoog bij de -29 heterozygoten en laag in de IVS II-849 heterozygoten). De vijf dubbele- heterozygoten vertoonden een thalassaemie intermediair met verhoogde $\mathrm{HbF}$ (hoge ${ }^{6} \gamma$ ), verhoogd $\mathrm{HbA}_{2}$ en $\mathrm{HbA}$ waarden vergelijkbaar met die van patiënten homozygoot voor de -29 mutatie of met de combinatie van deze $\beta^{+}$thalassaemie en $\mathrm{HbS}$. Een $\alpha$ thalassaemie-2 heterozygotie ( $-3,7 \mathrm{~kb}$ deletie) was aanwezig bij 2 patiënten. Hun haematologische waarden waren beter t.o.v. de patiēnten met vier $a$ globine genen; één daarvan was de moeder van twee tweelingen. De hoge $a^{a} \gamma$ waarde van het $\mathrm{HbF}$ van de dubbele heterozygoten geeft aan dat de hoge $\mathrm{HbF}$ produktie bij deze conditie voornamelijk afkomstig is van het chromosoom met de $-29(A \rightarrow G)$ mutatie.

In hoofdstuk $4 C$ worden 0.a. twee Surinaamse families, beiden van "mixed" origine beschreven, waarbij $\mathrm{HbA}_{2}$ en zijn variant $\mathrm{HbA}_{2}$ ' of $\mathrm{B}_{2}$ [d 16 (A 13) Gly $\ldots$ Arg] werd gekwantificeerd uit het bloed van deze individuen. Verder waren er ook $\beta$-thalassaemieen genen in cis of in trans van de $\partial-B_{2}$ variant aanwezig. In én familie was $\partial-\mathrm{B}_{2}$ mutatie in cis van het nieuw ontdekte codon $47(+A)$ frame shift $\beta$-thalassaemie gen. De percentages van $\mathrm{HbA}_{2}$ en $\mathrm{B}_{2}$ waren vijwel identiek, maar $70 \%$ hoger dan de $\mathrm{HbB}_{2}$ heterozygoten zonder een thalassaemie conditie. In twee andere families was de $\partial-B_{2}$ variant in trans van een deletie $\beta$-thal (1392 bp), waarbij een gedeelte van het $\beta$-globine gen en een gedeelte van de $\beta$-giobine promotor betrokken is, en in het tweede geval de -88 (C -. T) promotor mutatie. In beide gevallen was het $\mathrm{HbB}_{2}$ percentage met $80 \%$ verhoogd, terwijl het $\mathrm{HbA}_{2}$ percentage verhoogd was met respectievelijk 270 en $200 \%$. Deze 
gegevens indiceren 2 mechanismen welke betrokken zijn bij de verhoging van de $\partial$-keten produktie. Het ene is consistent met het algemene mechanisme, dat ervan uitgaat dat de relatieve overproduktie van $\alpha$-ketens bij $\beta$ keten deficiënties zal combineren met $\partial$ ketens om zodoende variërende percentages van $\mathrm{HbA}_{2}$ te vormen, afhankelijk van de ernst van de $\beta$-keten deficiëntie. Het tweede mechanisme neemt het verlies van het $\beta$-globine gen in aanmerking, veroorzaakt door de afwezigheid of verminderde binding van (een) specifieke eiwit(ten) aan dit DNA segment, met een gelijktijdig optreden van een verhoging van de promotor activiteit van het $\partial$-globine gen in cis.

In hoofdstuk $4 d$ wordt de dubbel heterozygotie voor de combinatie $\mathrm{HbE}$ en een $\beta$-thalassaemie gen beschreven. Gedurende het onderzoek naar haemoglobinopathieën in de Surinaamse populatie zijn 6 families gevonden met de combinatie $\mathrm{HbE}-\beta$-thalassaemie. Een uitgebreide vergelijking werd gemaakt van de klinische condities, haematologische data, $\mathrm{Hb}$ compositie en de typen $\beta$-thalassaemie allelen, aanwezig in deze Surinaamse $E$ - $\beta$-thalassaemie patienten met 28 patiënten van Malaysia, China en Georgia (USA). De meerderheid van de 28 patiēnten bezochten een haematologische kliniek in Kuala Lumpur, 5 waren afkomstig van het zuidelijk gedeelte van China en één patiēnt (D.D) van Georgia was van gemengd Koreaans-Italiaans afkomst. Alle patiënten van Suriname met de $E-\beta$ thalassaemie conditie waren van Indonesische of Indiase afkomst. Een totaal van 54 chromosomen van 27 individuen uit Suriname werden geanalyseerd, voornamelijk m.b.v. hybridisatie van specifieke oligonucleotide probes, na DNA amplificatie. Zes verschillende $\beta$-thalassaemie mutaties, inclusief de $\beta^{\mathrm{E}}$ mutatie werden aangetoond in deze 6 Surinaamse families. Ook werd een zeldzame splice function mutatie aangetoond [IVS 1-2 (T $\ldots, C)$, welke eerder was gevonden in een zwarte Amerikaanse tiener en een Algerijns kind.

In hoofdstuk 5 wordt een unieke vorm van $\partial-\beta$-thalassaemie beschreven welke is aangetoond in twee generaties van een Hidoestaans-Surinaamse familie. De propositus is een 19 jaar oude vrouw die maandelijks bloedtransfusies ontving. DNA van leden van deze familie is bestudeerd m.b.v. restrictie enzym analyse. Gene mapping studies toonden aan dat er geen abnormale $\alpha$-gen veranderingen waren in de zes bestudeerde individuen van de familie. Onderzoek van het $\beta$-globine gen, met gebruikmaking van de $\beta I V S I I$ en pRK 28 probes, indiceerden de aanwezigheid van een grootte deletie inhoudende de $\beta, \partial$ en $\psi \beta$ genen.

Het $3^{\prime}$ breekpunt van deze deletie lag $1 \mathrm{~kb} 3^{\prime}$ van het ${ }^{A} \gamma$ gen terwijl de deletie eindigt $10 \mathrm{~kb} 3^{\prime}$ van het $\beta$ gen, net buiten het gebied van repeterende 
sequenties genaamd $K p n 1$ of $L 1$. De minimale lengte van deze deletie wordt geschat op $31,6 \mathrm{~kb}$. Een IVS $1.5(\mathrm{G} \ldots \mathrm{C})$ mutatie was tevens aanwezig in de propositus (in trans) van de $\partial-\beta^{0}$ deletie. Vrij hoge foetaal $\mathrm{Hb}$ percentages (16-29\%) werden waargenomen in de heterozygoten van de Surinaamse $(\partial-\beta)^{0}$-thalassaemie met een gemiddelde ${ }^{G} \gamma:{ }^{A} \gamma$ ratio van $85: 15$. 


\section{EPILOOG}




\section{EPILOOG}

Het onderzoek naar de moleculaire karakterisatie van abnormale haemoglobines in de bevolking van Suriname werd om een aantal redenen ondernomen. In eerste instantie is een nadere studie welhaast een morele verplichting voor een uit deze populatie voortkomende onderzoeker, gezien de frequentie van met deze afwijkingen samenhangende ziektebeelden en de ernst van de aandoeningen, waarmee de patienten geconfronteerd worden. Deze morbiditeit trok dan ook reeds eerder de aandacht. Uit literatuuronderzoek is gebleken, dat er op zeer beperkte schaal een poging was ondernomen om de verschillende haemoglobine afwijkingen, voorkomend binnen onze multi-raciale gemeenschap, in kaart te brengen. Deze eerdere onderzoekingen concentreerden zich voornamelijk op de inheemse bevolking van Suriname, te weten de indianen en de boslandcreolen, en dateren van de jaren veertig en vijttig. De beperktheid van deze studies lag ten dele aan de in die vroegere dagen beschikbare technieken, waarbij het in principe alleen maar mogelijk was om met behulp van elctroforese op celluloseacetaat naar $\mathrm{Hb}$-varianten te zoeken.

A $\mathrm{l}$ in 1966 is echter door een werkgroep van de World Health Organisation vastgesteld (WHO Bulletin, 1966) dat er een nationaal gezondheidszorgprogramma met betrekking tot haemoglobinopathieën in Suriname noodzakelijk was.

De beschikbaarheid van moderne technieken zoals de Polymerase Chain Reaction (PCR), sequencing van geamplificeerd single strand DNA en dot blotting technieken, maken het thans mogelijk om zowel voor de $\mathrm{Hb}$ varianten als ook voor de thalassaemieēn tot precieze karakterisering te komen.

Met gebruikmaking van deze technieken is onderzoek gedaan naar de moleculaire compositie van genetische afwijkingen bij klinisch bekende haemoglobinopathie patienten en hun verwanten. Het nut van zodanig basaal onderzoek staat voor een Derde Wereld land als Suriname zeker ter discussie. Gelet echter op ook de sociale aspekten hiervan kan het nuttig aspect worden samengevat als hieronder geformuleerd.

Door middel van moleculair-genetische karakterisering van afwijkende haemoglobines is het mogelijk om:

1. de ernst van de diverse $\mathrm{Hb}$-pathieën bij patienten tijdig te voorspellen, waardoor geantecipeerd kan worden op adequate behandeling.

2. genetisch inzicht te verwerven in de onderhavige problematiek en de verworven kennis omtrent deze veel voorkomende ziekte beschikbaar te doen komen aan medici, studenten en aan de gehele samenleving. 
Uit ons onderzoek is komen vast te staan dat het ontbreken van kennis op dit gebied in enkele gevallen heeft geleid tot de premature dood van haemoglobinopathie patienten ten gevolge van onjuiste behandeling, waarbij gedacht moet worden aan onnodige en schadelijke toediening van ijzerpraeparaten. Ook wordt ten onrechte aan heterozygote dragers van o.a. het $\mathrm{HbS}$ gen meegedeeld, dat zij klachten vertonen, die gerelateerd worden aan het dragerschap.

Het grote aantal mensen (circa 75000 personen ofwel 1 van elke 4 Surinamers) in de Surinaamse bevolking dat drager iis van een haemoglobinopathie, vereist dat de gehele samenleving voor deze problematiek gesensibiliseerd moet worden. Hierbij gelden de volgende aanbevelingen:

* verplichte screening van pasgeborenen, om zodoende tijdig patienten op te sporen;

* opzetten van algemeen toegankelijke faciliteiten voor genetic counseling.

Het geheel aan maatregelen zal er dan toe moeten leiden dat er geen, op grond van de nieuwe inzichten vermijdbare, onjuiste behandeling van patienten meer plaats vindt. Ook zal het aantal hospitalisaties van patienten met haemoglobinopathie verminderen. In het kader van kosten/baten van de te nemen maatregelen moet onder de aandacht van de Surinaamse overheid gebracht worden dat, naast de winst aan menselijk geluk en welzijn, er van uit gegaan moet worden dat de vele dragers/patienten met haemoglobinopathie een langer en productiever leven beschoren zal zijn.

Zonder de medewerking van de vele door mij onderzochte patienten en hun verwanten zou het onderhavige onderzoek nimmer zijn voltooid; ik ben hun allen zeer erkentelijk voor hun vijwillige medewerking. Mijn hoop is ook daarom, dat dit onderzoek een beter inzicht in en gewaarwording van de problematiek van de haemoglobinopathie met zich meebrengt, waarvan de patienten profijt mogen hebben.

De uitwerking van mijn in dit proetschrift beschreven onderzoek is voornamelijk tot stand gekomen door de kennis en ervaring welke ik tijdens mijn twee-en-half jarige opleiding in de Afdeling 'Cell and Molecular Biology' (Hoofd: Prof. Dr. T.H.J. Huisman) van het Medical College of Georgia in Augusta/USA heb opgedaan. Ik wil dan ook op deze plaats alle medewerkers van deze Afdeling bedanken voor de fijne tijd, die ik tijdens mijn verblijf in de U.S.A. heb gehad, maar in het bijzonder Mrs. Cox, die gedeelten van mijn proefschrift van vele engelse taalfouten heeft ontdaan, en Mrs. Carver voor het typen van het manuscript. 
Alle goede dingen bestaan uit drie. Dit geldt zeker voor de drie geestesvaders zonder wier medewerking dit werk niet mogelijk was, te weten,

Dr. J.H. Wisse, hoofd van het klinisch-chemisch laboratorium van het Academisch Ziekenhuis in Paramaribo/Suriname, mijn eerste opleider in de klinische chemie. Hij was de ontdekker van één der haemoglobinevarianten en heeft het mij mogelijk gemaakt om het spoor uit te zetten bij mijn introductie in de haemoglobineresearch. Ik ben hem veel dank verschuldigd.

Prof. Dr. P.J. Brombacher, mijn promotor, die mede door zijn rust en zakelijke manier van organiseren de laatste loodjes minder zwaar heeft gemaakt. De warmte van $U$ en Uw wederhelft, ook tijdens de periode dat ik in Uw laboratorium werkzaam was, heb ik zeer op prijs gesteld.

Prof. Dr. T.H.J. Huisman. De goeroe achter dit onderzoek.

Beste Professor Huisman, ik ben $U$ zeer erkentelijk voor Uw kritische begeleiding bij het tot stand komen van dit proefschrift en voor de prettige en leerzame periode, die ik onder Uw supervisie heb mogen doorbrengen. $U$ heeft mij doen inzien dat zelfs de zon niet altijd voor niets op gaat.

Een bijzonder woord van dank gaat uit naar wijlen Herman Harris. Herman, jouw liefde voor de medemens zal mij altijd ten voorbeeld zijn in de rest van mijn leven. Dank zij jou heb ik mijn eerste succes op het gebied van de haemoglobine-afwijkingen geboekt, namelijk de ontdekking van het Haemoglobine-Wrens. Dit proefschrift draag ik mede ter nagedachtenis aan jou op.

De laboratoriummedewerkers van het Academisch Ziekenhuis te Paramaribo/Suriname en van het De Wever-Ziekenhuis te Heerlen/Nederland, die op enigerlei wijze hebben bijgedragen aan dit proefschrift, wil ik hierbij volgaarne dank zeggen.

Een woord van dank gaat uit naar iemand, die mij verzocht heeft geen gewag te maken van haar medewerking, maar waarvan ik het toch mijn plicht acht om dit tenminste incognito te doen: K.M.E., jouw steun en inspiraties tijdens mijn middernachtelijke expedities in het laboratorium van het Medical College of Georgia waren van onschatbare waarde. Hartelijk dank daarvoor.

Ongedeeld, maar toch in drieèn gaat mijn dank tenslotte uit naar mijn Schepper, God de Almachtige, naar mijn ouders Frits en Hermien, en naar mijn dochter Soleil N'didi; zonder jullie was er nooit een begin en ook geen einde gekomen. Bedankt voor het geduld en ik zal altijd van jullie blijven houden. 


\section{Curriculum vitae}

Onder het sterrebeeld Vissen werd John Frits Codrington in 1958 in Paramaribo/Suriname geboren.

In 1975, na het behaien van het Atheneum-B diploma aan de Algemene Middelbare School (AMS) in Paramaribo, vertrok hij naar Nederland om zich aldaar aan de Technische Universiteit te Delft in te schrijven voor een studie in de Chemische Technologie. In 1978 werd deze opleiding verruild voor de studie Scheikunde aan de Rijksuniversiteit te Leiden, waar in september 1983 het candidaatsexamen met goede resultaten werd afgelegd. In januari 1986 slaagde hij voor het doctoraalexamen met hoofdvak Biochemie.

In februari 1986 begon hij met de opleiding tot klinisch chemicus in het De Wever-Ziekenhuis te Heerlen (opleider Prof.Dr. P.J. Brombacher), gevolgd van december $1986 \mathrm{t} / \mathrm{m}$ maart 1987 door een stage in het laboratorium van het Wilhelmina Kinderziekenhuis te Utrecht onder supervisie van Dr. G. van Stekelenburg. De opleiding werd voortgezet, van april $1987 \mathrm{t} / \mathrm{m}$ juli 1988, in het laboratorium van het Academisch Ziekenhuis te Paramaribo (opleider Dr. J.H. Wisse) en afgesloten met een stage van augustus 1988 $\mathrm{t} / \mathrm{m}$ december 1990 in de het laboratorium van de Faculty of Cell and Molecular Biology (opleider Prof.Dr. T.H.J. Huisman), Medical College of Georgia, Augusta/Georgia/U.S.A. In deze periode werd ook het materiaal verzameld en bewerkt met betrekking tot het in dit proefschrift beschreven onderzoek.

In mei 1991 volgde de registratie als Klinisch Chemicus in het Specialisten Register van de Vereniging van Medici in Suriname.

Vanaf de registratie als specialist is John Frits Codrington werkzaam als klinisch chemicus in het Academisch Ziekenhuis te Paramaribo/Suriname. Tevens is hij vanaf april 1991 Commissaris van de Bloedtransfusiedienst van het Surinaamse Rode Kruis en Lid van het Nationale Aids Comité van Suriname.

Van zijn hand verschenen tot nu toe een twaalftal artikelen in internationale wetenschappelijke tijdschriften op klinisch-chemisch en haematologisch gebied. 
Met dank wordt vermeld dat de uitgave van dit proetschrit is mogelijk gemaakt docr financiële steun van Roche Nederland B.V. to Mijdrecht on van de Stichting Dr.Ir. J.H.J. van der Laer te Heerien 
